


\section{SISTEMA PÚBLICO DE BICICLETAS COMPARTILHADAS a disputa do espaço urbano}

Versâo Original

Dissertaçâo apresentada à Faculdade de Arquitetura e Urbanismo da Universidade de Sáo Paulo para a obtençấo do título de Mestre em Arquitetura e Urbanismo.

Área de Concentraçấo: Paisagem e Ambiente Orientador: Prof. Dr. Fábio Mariz Gonçalves 
Autorizo a reproduçâo e divulgaçăo total ou parcial deste trabalho, por qualquer meio convencional ou eletrônico, para fins de estudo e pesquisa, desde que citada a fonte.

E-mail da autora: renata.rabello@usp.br

Capa: Ilustraçâo de Catarina Bessell para “Um Quintal Maior que o Mundo”, projeto realizado no Sesc Avenida Paulista (julho 2018)

Projeto gráfico e diagramaçăo: Carolina La Terza

Catalogaçăo na Publicaçăo

Serviço Técnico de Biblioteca

Faculdade de Arquitetura e Urbanismo da Universidade de Sâo Paulo

Rabello, Renata Cruz

Sistema público de bicicletas compartilhadas: a disputa do espaço urbano /

Renata Cruz Rabello; orientador Fábio Mariz Gonçalves. - Săo Paulo, 2019. 337p.

Dissertaçâo (Mestrado) - Faculdade de Arquitetura e Urbanismo da

Universidade de Săo Paulo. Área de concentraçăo: Paisagem e Ambiente

1. Mobilidade Urbana. 2. Bicicletas. 3. Paisagem Urbana.

I. Gonçalves, Fábio Mariz, orient. II. Título. 


\section{Folha de aprovação}

Rabello, Renata Cruz. Sistema Público de Bicicletas Compartilhadas: a disputa do espaço urbano. 2019. Dissertaçăo apresentada à Faculdade de Arquitetura e Urbanismo da Universidade de Săo Paulo para obtençăo do título de Mestre e Arquitetura e Urbanismo.

Aprovada em:

\section{Banca examinadora}

Prof(a). ${ }^{(a)}$. Instituiçăo:

Julgamento: Assinatura:

Prof ${ }^{(a)}$. Dr ${ }^{(a)}$. Instituiçâo:

Julgamento: Assinatura:

$\operatorname{Prof}{ }^{(a)}$. $\operatorname{Dr}^{(a)}$. Instituiçăo:

Julgamento: Assinatura: 



\section{Agradecimentos}

Agradeço ao meu orientador, Fábio Mariz Gonçalves, pelas palavras sempre coerentes e instigantes sobre a vitalidade do espaço urbano.

Aos colegas do trabalho, por compartilharem o sonho de uma cidade repleta de ciclistas. Em especial ao Mauricio Villar, Juliana Minorello e à equipe de projetos da Tembici, Débora Gonçalves, Marina Marques, Mariana Gontow, Janaina Lima, Lucas Pacobahyba e Esteban Sanchez, pelas leituras, sugestōes e convivênvia.

À Ciclocidade, pela contagem de ciclistas realizada em dezembro de 2018.

À Carol La Terza pela linda diagramaçăo do trabalho, em especial pela padronizaçâo dos gráficos e mapas.

À Catarina Bessell pela criatividade da ilustraçâo da capa da dissertaçáo e ao Sesc Avenida Paulista pela autorizaçăo do uso.

À Luísa Cruz de Melo, pelas fotos tiradas em fevereiro de 2019.

Aos meus pais e meus irmáos, pelo caráter, responsabilidade e comprometimento ensinados.

Ao Roberto Bobadilha Neumann, parceiro da vida toda, por abrir meus olhos para o mundo da bicicleta e por me fazer muito feliz. 


\section{Resumo}

O objetivo desta dissertaçăo é colaborar com a avaliaçăo da contribuiçăo do sistema público de bicicletas compartilhadas como complemento da mobilidade urbana, com o intuito de mensurar seu papel e relevância na disseminaçấo da bicicleta como meio de transporte e elemento presente no cotidiano da paisagem. Os sistemas públicos de bicicletas compartilhadas mostraram-se viáveis e importantes para a locomoçâo dentro da cidade, com o aperfeiçoamento da tecnologia, dos equipamentos e da gestăo do serviço.

A alta adesâo da populaçăo ao uso de modais de compartilhamentos ativos reflete a demanda reprimida por diferentes formas de deslocamento além do automóvel. Os investimentos públicos que priorizaram o veículo para uso individual em muitas cidades năo se justificam mais e devem ser redirecionados ao transporte público, aos modais ativos que complementam sua acessibilidade e à infraestrutura que viabiliza sua segurança. A intermodalidade é essencial nos grandes centros para expandir o acesso às estaçôes de transporte de massa e, portanto, a inclusâo social e o direto ao usufruto da cidade. Como exemplo, sâo mostrados os dados do sistema público de bicicleta compartilhada Bike Sampa, da cidade de Sáo Paulo.

No entanto, somente quando o poder público considerar os modais ativos como parte da mobilidade urbana e efetivar a redistribuiçăo do espaço público urbano de modo mais equitativo entre os modais, a bicicleta terá maior abrangência no território e poderá alcançar número ainda maior de usuários diários. Qualquer mudança na distribuiçăo do 
aproveitamento do espaço público traz de imediato resistências, por modificar alguns costumes e ideias consolidadas da populaçăo e de vários agentes públicos e privados. A experimentaçăo concreta é reconhecida pelo urbanismo contemporâneo como a ferramenta que possibilita o contato com soluçôes diferentes, por quebrar resistências às propostas que pareciam impossíveis à vivência cotidiana.

RABELLO, Renata Cruz. Sistema Público de Bicicletas Compartilhadas: a disputa do espaço urbano. Sâo Paulo, Dissertaçāo de Mestrado FAUUSP. 2019.

Palavras-chave: Mobilidade urbana - Săo Paulo (SP) e Brasil. Mobilidades ativas - Săo Paulo (SP). Sistema público de bicicletas compartilhadas. 


\section{Abstract}

The objective of this dissertation is to collaborate with the evaluation of the Public Bicycle Sharing (PBS) system as a complement to urban mobility, analyzing its role and importance in the diffusion of the bicycle as a means of transport and element present in the daily life of the landscape. Public Bike Sharing Systems have proved viable and important for urban mobility over time, with improved technology, equipment and service management.

The high acceptance of the population to the use of shared active mobility reflects the repressed demand existing in the cities for alternative means of transport, besides the automobile. Public investments that prioritized individual vehicles are no longer justified and should be redirected to public transport and to the active modalities that complement their accessibility and the infrastructure that makes their safety possible by sharing the urban space. Intermodality is essential in large cities, expanding access to mass transit stations, to social inclusion and to the enjoyment of the city. As an example, the data of the PBS Bike Sampa, of the City of Sâo Paulo, is demonstrated.

However, only when the public authority considers active modalities as part of urban mobility, redistributing the urban public space more fairly between modes of transport, the use of the bicycle will have greater scope in the territory, reaching an even greater number of daily users. Any change in the distribution of the use of the public space immediately brings resistance, by modifying some customs and consolidated ideas of the population and of several public and private agents. Concrete 
experimentation is recognized by contemporary urbanism as the tool that enables contact with different solutions, breaking resistances, to proposals that seemed impossible through daily living.

RABELLO, Renata Cruz. Public Bike Sharing System: the urban space dispute. Sáo Paulo, Thesis presented to FAUUSP. 2019.

Keywords: Urban Mobility - Sáo Paulo (SP) and Brazil. Active mobilities Sâo Paulo (SP). Public Bicycle Sharing system (PBS). 


\section{Lista de Figuras}

Figura 1 | Sete elementos de um bairro DOTS ............................................................................................... 50

Figura 2 | Oito princípios de DOTS........................................................................................................................ 52

Figura 3 | Representação das distâncias no anúncio do empreendimento imobiliário................. 54

Figura 4 | Relação de acessibilidade da moradia a estações de transporte público entre pedestres e ciclistas .................................................................................................................................................... 55

Figura 5 | PNT de São Paulo...................................................................................................................................... 56

Figura 6 | PNT por acesso a pé de outras cidades...................................................................................... 57

Figura 7 | Provocação n05: o plano da bicicleta branca.............................................................................. 66

Figura 8 | La Rochelle 1976 _................................................................................................................................. 73

Figura 9 | Reconhecimento da bicicleta como veículo........................................................................... 131

Figura 10 | Plano Municipal de Mobilidade de São Paulo ...................................................................... 147

Figura 11 | Estação de bicicletas compartilhadas da PBSC..............................................................157

Figura 12 | Esquema de funcionamento do Bike Sampa com a Estação Bike............................... 187

Figura 13 | Cartilha para embaixadores da Estação Bike 12 horas Cidade Tiradentes............ 192

Figura 14 | Explicação do funcionamento do sistema.................................................................... 238

Figura 15 | Cresce movimento na ciclovia da av. Brigadeiro Faria Lima, em SP.......................... 250

Figura 16 | Fluxo de ciclistas no eixo da Avenida Brigadeiro Faria Lima e na Avenida Rebouças..... 256

Figura 17 | Reclamação de paulistano sobre a estação Bike Sampa............................................... 291 



\section{Lista de Fotos}

Foto 1 | Estação de Metrô Faria Lima e ciclovia da Faria Lima............................................................... 34

Foto 2 | Estação de Metrô Faria Lima e Estação 1 (Largo da Batata) do Bike Sampa................. 34

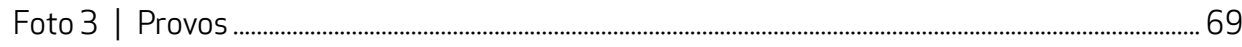

Foto 4 | Plano da bicicleta branca................................................................................................................... 70

Foto 5 | Bicicletas brancas no Parque Nacional De Hoge Veluwe............................................................ 72

Foto 6 | Bicicletas compartilhadas (ByCyklen) em Copenhague (1995)............................................. 75

Foto 7 | Sistema Velo'v, em Lyon....................................................................................................................

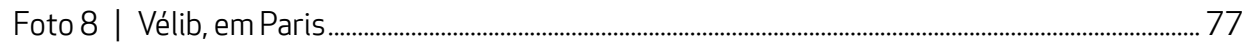

Foto 9 | Bicing, em Barcelona (2007) ................................................................................................................. 79

Foto 10 | Bixi, em Montreal .................................................................................................................................... 79

Foto 11 | Hangzhou, em China............................................................................................................................ 80

Foto 12 | Diferente modelos de travas de bicicleta dockless ...............................................................97

Foto 13 | Exemplos de vandalismo de bicicletas do sistema dockless na China.......................... 101

Foto 14 | Excesso de bicicletas de diferentes empresas bloqueando a calçada na China...... 101

Foto 15 | Bicicletas dockless de diferentes empresas na entrada do parque Xiashan em Shenzhen (China), em janeiro de 2017: problema da superlotação no espaço público ............... 102

Foto 16 | Bicicletas dockless atrapalham caminho em Beijing (China), em janeiro de 2017.102

Foto 17 | Trabalhador pedala abicicleta compartilhada ao lado da pilha de bicicletas inutilizadas em um terreno baldio em Xiamen (China), em dezembro de 2017 103

Foto 18 | Cemitério de bicicletas na China: problema de descarte e baixa durabilidade e manutenção, em janeiro de 2018, em Xiamen (China) ........................................................................... 103

Foto 19 | Milhares de bicicletas dockless inutilizadas em campo próximo de Shanghai......... 104

Foto 20 | Bicicletas abandonadas da Bluegogo após falência..............................................................105

Foto 21 | Estação de bicicleta elétrica na Cidade do México (Ecobici), 2018............................... 111

Foto 22 | Nova estação de bicicleta mista em Barcelona (Bicing), 2019......................................... 111

Foto 23 | Bicicletas dockless elétricas Jump, travadas com seu cadeado em paraciclo.......... 112 
Foto 24 | Patinetes elétricos da Lime em Portland (Estados Unidos)............................................... 116

Foto 25 | Usuária do patinete elétrico Bird em Washington DC ............................................................ 117

Foto 26 | Patinete elétrico Scoot travado em suporte fixo, em São Francisco ............................. 118

Foto 27 | Patinete Petrobras, no Rio de Janeiro, operado pela Tembici............................................ 122

Foto 28 | Ciclovia da AvenidaBrigadeiro FariaLima até2012. Trecho sem saída da cicloviano canteiro central, construída com o prolongamento da avenida na gestão do prefeito Paulo Maluf.........................150

Foto 29 | Ponte Octávio Frias de Oliveira em São Paulo, com proibição de acesso a pedestres e ciclistas. 151

Foto 30 | Bike PoA, estação 7 - Usina do Gasômetro, no paralelepípedo ........................................ 158

Foto 31 | Bike PoA, estação 41 - Iberê, na grama............................................................................... 159

Foto 32 | Bolsão da Estação 1 (Largo da Batata) ..............................................................................161

Foto 33 | Estação 1 (Largo da Batata) à esquerda, bolsão à direita (próximo à banca de jornal) e fluxo de ciclistas no final do dia na devolução das bicicletas para integração com o Metrô..... 161

Foto 34 | Entrada do bicicletário Estação Bike Cidade Tiradentes.................................................. 188

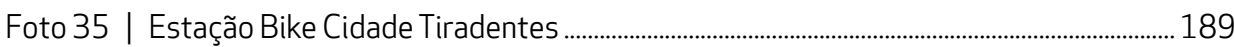

Foto 36 | Festival Estação Bike Cidade Tiradentes, em 9 de dezembro de 2018....................... 192

Foto 37 | Bicicletas customizadas, pelo coletivo OTM, do projeto Arte na Bike selecionado no FAB-CT 193

Foto 38 | Bicicletas customizadas compartilhadas da Estação Bike Cidade Tiradentes........ 193

Foto 39 | Sistema Ecobici na Cidade do México......................................................................................220

Foto 40 | Sistema Ecobici na Cidade do México....................................................................................220

Foto 41 | Usuários do sistema Ecobici na Cidade do México ............................................................221

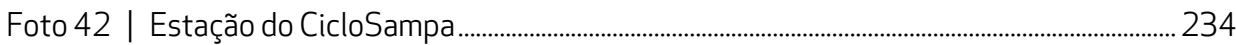

Foto 43 | Ponto fisíco de devolução de bicicleta dockless em São Paulo........................................ 239

Foto 44 | Ponto fisíco de devolução de bicicleta dockless em São Paulo........................................ 240

Foto 45 | Estação do Bike Sampa no leito carroçável, e bicicletas e patinetes dockless ao lado...... 241 
Foto 46 | Ciclistas na ciclovia da av. Brigadeiro Faria Lima.

Foto 47 | Ciclistas parados no semáforo da ciclovia da Avenida Brigadeiro Faria Lima .......... 251

Foto 48 | Foto de ciclista utilizando Bike Sampa em 2015.................................................................... 254

Foto 49 | Fila de ciclistas no semáforo da ciclovia da Faria Lima, esquina com a Avenida

Rebouças, com a presença de muitas bicicletas compartilhadas do Bike Sampa .......................... 262

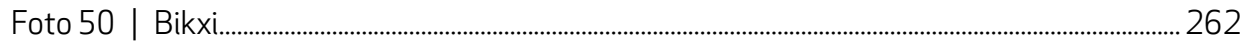

Foto 51 | Patinete elétrico compartilhado (Grin) ...................................................................................2 263

Foto 52 | Bicicletas de serviço de entrega ............................................................................................... 263

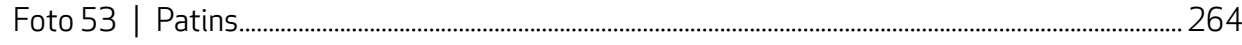

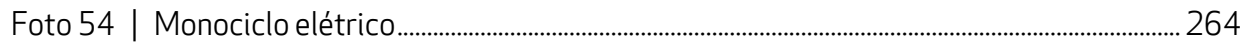

Foto 55 | Paineis interativos no Parque Ibirapuera................................................................................ 268

Foto 56 | Paineis interativos no Largo da Batata............................................................................... 268

Foto 57 | Usuários aguardam a chegada de bicicletas na Estação 1 - Largo da Batata do

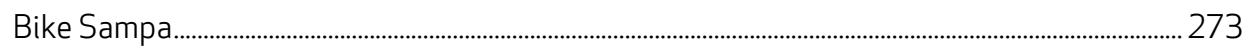

Foto 58 | Ciclistas retiram as bicicletas compartilhadas no período da manhã na estação 1 do Bike Sampa, próximo ao Metrô Faria Lima.................................................................................................. 273

Foto 59 | Ciclistas aguardam abertura do semáforo do cruzamento da Avenida Brigadeiro Faria Lima e Rua Teodoro Sampaio, no período da manhã.............................................................................. 274

Foto 60 | Ciclistas aguardam a abertura do semáforo no cruzamento da Avenida Brigadeiro Faria Lima com a Rua Teodoro Sampaio, no final da tarde. 274

Foto 61 | Ciclistas atravessam o cruzamento da Avenida Brigadeiro Faria Lima com a Rua Teodoro Sampaio, em direção ao Metrô Faria Lima, no final da tarde 275

Foto 62 | Foto dos cartazes de reclamação colados pelos comerciantes na estação de bicicletas compartilhadas (dezembro de 2018) .......................................................................................... 290

Foto 63 | Praça Ernani Braga (São Paulo), em 2011 e 2017 ................................................................. 294

Foto 64 | Intervenção em cruzamento do bairro de Santana consolidada pela CET .................. 302 
Foto 65 | Cruzamento de Santana antes e depois da intervenção viária ......................................... 303

Foto 66 | Times Square antes e depois das intervenções........................................................................ 304

Foto 67 | Avenida Central da Cidade 2000, em Fortaleza ........................................................................ 304

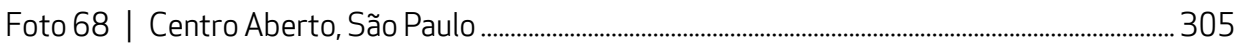

Foto 69 | Rua Galvão Bueno, em São Paulo, com a ampliação da calçada e criação de espaços de convivência 305

Foto 70 | Faixa verde para pedestres na Avenida Liberdade em 2015 e obra da calçada em 2019 306

Foto 71 | Estação de bicicletas compartilhadas em Nova lorque. 307 


\section{Lista de Gráficos}

Gráfico 1 | Crescimento do número de sistemas públicos de compartilhamento de bicicleta, de 2005 a maio de 2018 61

Gráfico 2 | Crescimento da frota de bicicletas compartilhadas, de 2014 a 2018. 62

Gráfico 3 | Países com maior quantidade de SPBC, em 2016. 62

Gráfico 4 | Bicicletas compartilhadas no mundo e na China, em 2016. 63

Gráfico 5 | Quantidade de bicicletas compartilhadas e viagens realizadas nos Estados Unidos de 2010 a 2017 63

Gráfico 6 | Comparativo de velocidade de deslocamento em diferentes modais no ambiente urbano 83

Gráfico 7 | Uso dos sistemas de compartilhamento de bicicletas: número de viagens/dia/ bicicleta (VDB) e a densidade de estações. 91

Gráfico 8 | Início da operação de Sistemas Dockless e viagens realizadas por automóveis em distâncias menores de cinco quilômetros em Beijing e em Shanghai. 99

Gráfico 9 | Comparação do número de bicicletas compatilhadas dockless e com estação, com as respectivas quantidades de viagens realizadas nos Estados Unidos em 2017. 108

Gráfico 10 | Padrão de viagens por horário do dia em sistema de bicicletas compartilhadas com estação. 109

Gráfico 11 | Relação do uso diário de bicicletas elétricas Jump e carros Uber, em São Francisco. 113

Gráfico 12 | Comparação das viagens mensais do sistema de bicicleta e patinete elétrico dockless em quatro cidades americanas.

Gráfico 13 | Número de viagens dos diferentes modais e o número de acidentes e colisões, no período piloto de bicicletas e patinetes elétricos dockless em Washington 119

Gráfico 14 | Principal problema enfrentado no uso da bicicleta, em 2015. 133

Gráfico 15 | Principal problema enfrentado no uso da bicicleta, em 2018. 134

Gráfico 16 | Divisão Modal das viagens realizadas no Município de São Paulo em 2007....... 135 
Gráfico 17 | Usuário diário da bicicleta por gênero em 2009.

Gráfico 18 | Tipo de bicicleta utilizada: privada ou pública

Gráfico 19 | Tipo de bicicleta e a distribuição por gênero 138

Gráfico 20 | Área da cidade e distribuição por gênero 139

Gráfico 21 | Área da cidade e distribuição por escolaridade (considerado o último segmento completo). 141

Gráfico 22 | Área da cidade e distribuição por renda (salário mínimo de R\$788,00) 141

Gráfico 23 | Relação do número de estações e de viagens dos últimos dois anos dos sistemas Bike Rio, Bike Sampa, Bike Salvador, Bike PE e Bike PoA 156

Gráfico 24 | Relação entre o número de estações do Bike Sampa e as viagens mensais, de outubro de 2016 a janeiro de 2019 198

Gráfico 25 | Viagens por hora por dia no mês de janeiro de 2019 no Bike Sampa 202

Gráfico 26 | Viagens por hora por dias de semana no mês de janeiro de 2019 no Bike Sampa, por gênero 202

Gráfico 27 | Viagens por hora por dias de fim de semana no mês de janeiro de 2019 no Bike Sampa, por gênero. 203

Gráfico 28 | Moda da duração das viagens dos sistemas brasileiros (Bike Sampa, Bike Rio, Bike PoA, Bike Salvador, Bike PE e Bike VV) 204

Gráfico 29 | Moda das viagens do Bike Sampa ..................................................................................... 205

Gráfico 30 | Quantidades de estações por mês de 2012 a janeiro de 2019 .212

Gráfico 31 | Quantidade de bicicletas por mês de 2012 a janeiro de 2019. .212

Gráfico 32 | Quantidade de viagens por mês de 2012 a janeiro de 2019. 212

Gráfico 33 | Quantidade de viagens por dia em cada mês de 2012 a janeiro de 2019 214

Gráfico 34 | Quantidade de viagens por dia por bicicleta em cada mês de 2012 a janeiro de 2019 214

Gráfico 35 | Viagens por dia de semana e por dia de final de semana no Bike Sampa 216 
Gráfico 36 | Viagens com devolução na mesma estação ou em estações diferentes 217

Gráfico 37 | Duração das viagens totais do Bike Sampa. 217

Gráfico 38 | Pesquisa com usuários do Ecobici em 2014: antes de utilizar o ECOBICl, usava a bicicleta como meio de transporte? Com que frequência? 222

Gráfico 39 | Pesquisa com usuários do Ecobici em 2014: como descobriu o ECOBICI?.......... 223

Gráfico 40 | Pesquisa com usuários do Ecobici em 2014: integração modal ................................ 223

Gráfico 41 | Comparação da quantidade de estações do Bike Sampa e Ecobici desde a inauguração até o fim de 2018. 227

Gráfico 42 | Comparação da quantidade de bicicletas do Bike Sampa e Ecobici desde a inauguração até o fim de 2018. 227

Gráfico 43 | Comparação da quantidade de viagens por ano do Bike Sampa e Ecobici desde a inauguração até o fim de 2018. 228

Gráfico 44 | Comparação da quantidade de viagens por dia do Bike Sampa e do Ecobici nos últimos doze meses 228

Gráfico 45 | Comparação das viagens por dia por bicicleta do Bike Sampa e do Ecobici dos últimos doze meses 229

Gráfico 46 | Viagens totais e nos fins de semana realizadas com devolução na mesma estação ou em estações distintas de janeiro de 2018 a janeiro de 2019, no Ecobici 230

Gráfico 47 | Viagens totais e nos fins de semana realizadas por até 45 minutos de janeiro de 2018 a janeiro de 2019, no Ecobici 230

Gráfico 48 | Viagens totais e nos fins de semana realizadas com devolução na mesma estação ou em estações distintas de janeiro de 2018 a janeiro de 2019, no Bike Sampa 231 Gráfico 49 | Viagens totais e nos fins de semana realizadas até sessenta minutos de janeiro de 2018 a janeiro de 2019, no Bike Sampa 232

Gráfico 50 | Viagens totais e nos fins de semana por gênero no Ecobici, nos últimos doze meses (de janeiro de 2018 a janeiro de 2019) 
Gráfico 51 | Viagens totais e nos fins de semana por gênero no Bike Sampa, nos últimos doze

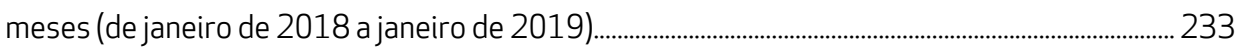

Gráfico 52 | Contagem mensal de ciclistas na rua Vergueiro, desde o início (18/01/2016 até

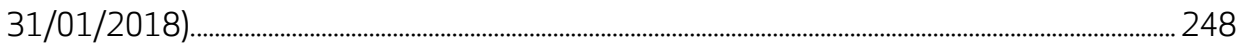

Gráfico 53 | Número de ciclistas em 2013, 2015 e 2018...................................................................... 257

Gráfico 54 | Fluxo de ciclistas por hora em 2013, 2015 e 2018 .......................................................... 258

Gráfico 55 | Modais de deslocamento próprios e compartilhados ................................................... 259

Gráfico 56 | Modais ativos contabilizados na contagem de 2018 ..................................................... 260

Gráfico 57 | Número total de bicicletas compartilhadas....................................................................... 261

Gráfico 58 | Bike sampa por turno de contagem em 2013, 2015 e 2018..................................... 261

Gráfico 59 | Meio de transporte nos deslocamentos cotidianos ......................................................... 269

Gráfico 60 | Meio de transporte idealizado para os deslocamentos cotidianos.......................... 269

Gráfico 61 | Motivo para não utilizar a bicicleta no dia a dia................................................................ 270

Gráfico 62 | Meio de transporte utilizado antes da bicicleta. ..............................................................2 270

Gráfico 63 | Número de ciclistas por dia que foram contabilizados no Contador de ciclistas da Avenida Brigadeiro Faria Lima. 297

Gráfico 64 | Número de ciclistas por dia que foram contabilizados no contador de ciclistas da Avenida Brigadeiro Faria Lima de $1^{\circ}$ de maio de 2018 a 31 de janeiro de 2019. 298

Gráfico 65 | Viagens por dia no Bike Sampa entre 1 de maio de 2018 e 30 de junho de 2018 .... 299 


\section{Lista de Mapas}

Mapa 1 | Eixo da Ciclovia desde a Avenida Gastão Vidigal até a Avenida Chucri Zaidan............. 35

Mapa 2 | Áreas próximas ao sistema de transporte de alta e média capacidade da Região

Metropolitana de São Paulo 59

Mapa 3 | Município de São Paulo e as 259 estações do sistema Bike Sampa, em 2015 ........ 177

Mapa 4 | Rede de estações na região da Avenida Brigadeiro Faria Lima, em dezembro de 2017 e em dezembro de 2018. Localização das estações indicada com circunferência de raio de 200 metros 179 Mapa 5 | Sistema Bike Sampa, na cidade de São Paulo, com indicação da quantidade de retiradas de bicicletas compartilhadas por estação (dados de novembro de 2016) 181

Mapa 6 | Sistema Bike Sampa previsto para a cidade de São Paulo, que mostra a localização das estações do plano que seria implantado até junho de 2018 ............................................................ 184

Mapa 7 | Sistema Bike Sampa em janeiro de 2019 .............................................................................. 185

Mapa 8 | Quantidade de viagens realizadas de cada estação do Bike Sampa (dez 2018 e jan 2019) .............................................................................................................................................................. 206

Mapa 9 | Fluxos de viagem entre estações do Bike Sampa (dez 2018 e jan 2019) .................. 207

Mapa 10 | Local de moradia dos usuários do Bike Sampa, por CEP................................................. 209

Mapa 11 | Sistema Ecobici, Cidade do México, com faseamento das instalações ..................... 219

Mapa 12 | Cidade de São Paulo e Cidade do México com os respectivos SPBC .......................... 224

Mapa 13 | Cidade de São Paulo até janeiro de 2018 e Cidade do México com os respectivos SPBC. Circunferência com 200 metros de raio................................................................................................... 225

Mapa 14 | Estaç̃̃es do CicloSampa em São Paulo.............................................................................. 235

Mapa 15 | Área de atendimento das bicicletas dockless Yellow Bike ............................................ 237

Mapa 16 | Pontos de patinetes Scoo e área de cobertura da Yellow e da Grin ............................. 243

Mapa 17 | Área de cobertura dos operadores de bicicletas e patinetes compartilhados de

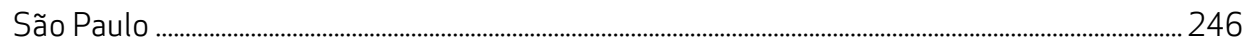

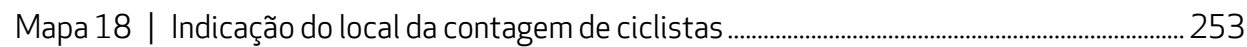

Mapa 19 | Localização da pesquisa do Cidade Ativa e estações do Bike Sampa....................... 266 



\section{Lista de Tabelas}

Tabela 1 | PNT separado por faixas de renda por salário mínimo da cidade de São Paulo ................... 57

Tabela 2 | Porcentual de viagens de cada modal substituído pelo SPCB em Barcelona, Montreal,

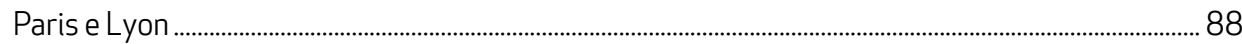

Tabela 3 | Valor médio do custo de uma viagem de 15 minutos nos diferentes modais de compartilhamento, em São Paulo. 123

Tabela 4 | Valor médio do custo de uma viagem de 5 km nos diferentes aplicativos de carona, em São Paulo

Tabela 5 | Custo anual dos meios de transporte para o trajeto de 7,5km de ida e volta para o trabalho 125

Tabela 6 | Registro do acréscimo das viagens realizadas por bicicletas no Município de São

Paulo em 1997 e 2007 - modal único e integrado a outros modais 136

Tabela 7 | Características dos SPBC, em 2015, em São Paulo, Nova York e Cidade do México... 178

Tabela 8 | Porcentagem de usuários que moram fora da área de cobertura do SPBC. 208

Tabela 9 | Custo de cada operador de sistemas de bicicletas compartilhadas de São Paulo $[A] R \$ 5,00$ a cada sessenta minutos seguidos adicionais 247

Tabela 10 | Custo de cada operador de sistemas de patinetes elétricos compartilhados e do sistema Bikxi

Tabela 11 | Contagem do mês de setembro em 2016, em 2017 e em 2018

Tabela 12 | Características das pessoas na contagem 2018, sendo o total 9.111 pessoas (100\%) 



\section{Abreviaturas e siglas}

BRT - Transporte Rápido por Ônibus. Traduçăo do termo em inglês Bus Rapid Transit.

CEBRAP - Centro Brasileiro de Análise e Planejamento. O CEBRAP foi criado em 1969 e realiza pesquisas com foco na análise da realidade brasileira, com ênfase na interdisciplinaridade, de modo a contribuir na avaliaçâo das açōes públicas.

CMUV - Comitê Municipal do Uso do Viário

CET - Companhia de Engenharia de Tráfego de Săo Paulo

CET-Rio - Companhia de Engenharia de Tráfego do Rio de Janeiro

Código QR - Quick Response Code. Código QR é um código de barras

bidimensional que pode ser escaneado pela maioria dos telefones celulares equipados com câmera.

CONTRAN - Conselho Nacional de Trânsito

CPTM - Companhia Paulista de Trens Metropolitanos

CTB - Código de Trânsito Brasileiro

CTTU - Autarquia de Trânsito e Transporte Urbano do Recife

DENATRAN - Departamento Nacional de Trânsito

DDOT - District Department of Transportation (Departamento Distrital de Transportes, traduçâo nossa)

DIFU - Deutsches Institut Für Urbanistik (Instituto Alemăo para

Planejamento Urbano, traduçăo Google)

DOT - Desenvolvimento Orientado ao Transporte. Traduçăo do termo em inglês Transit Oriented Development (TOD)

DOTS - Desenvolvimento Orientado ao Transporte Sustentável

DPM - Departamento de Planejamento de Modos Ativos 
ECF - PEBBS - European Cyclists' Federation (Federaçăo Europeia de Ciclistas) - Platform for European Bicycle Sharing \& Systems (Plataforma para os Sistemas Europeus de Bicicleta Compatilhada), traduçăo nossa. A ECF tem o objetivo de promover o ciclimos como modos de transporte e lazer sustentáveis e saudáveis.

EWGT - EURO Working Group on Transportation. (Grupo de trabalho em Transporte da Europa, traduçâo nossa).

O objetivo principal do EWGT, fundado em 1991 na Itália, é o compartilhamento de informaçōes e experiências de pesquisa, com foco no transporte e logística. FAB - Fundo de Apoio da Bicicleta. O FAB fomenta projetos comunitários nas periferias de Săo Paulo para a construçăo da mobilidade segura, inclusiva e eficiente, com foco na bicicleta.

FAUUSP - Faculdade de Arquitetura e Urbanismo da Universidade de Sâo Paulo

GEIPOT - Empresa Brasileira de Planejamento de Transportes

GPS - Global Positioning System (Sistema de Posicionamento Global) ITDP - Instituto de Políticas de Transporte e Desenvolvimento. O ITDP é uma organizaçăo sem fins lucrativos, cuja missâo é fomentar o transporte ambientalmente sustentável e equitativo ao redor do mundo. A capacidade técnica consiste no projeto de sistemas de transporte, com prioridade em transporte público e na promoçăo dos modos ativos de deslocamento, além do Desenvolvimento Orientado ao Transporte (DOT). A organizaçâo conta com especialistas em transporte urbano sustentável e tem o objetivo de atingir o equilíbrio entre o crescimento e o planejamento de baixo carbono, com a intençâo de reduzir as mortes no trânsito e a desigualdade social. 
NABSA - North American Bikeshare Association (Associaçăo Norte Americana de Compartilhamento de Bicicleta, traduçăo nossa).

A associaçâo conecta os maiores conhecedores de sistemas de compartilhamento de bicicleta para contribuir com sua promoçăo na américa do norte, com representaçăo de empresas operadoras dos sistemas, poder público, desenvolvedores da tecnologia e dos equipamentos.

NACTO GDCI - Associaçăo Nacional de Gestores de Transporte Urbano - Iniciativa Global de Desenho de Cidades (da sigla em inglês National Association of City Transportation Officials - Global Designing Cities Initiative).

É uma associaçấo sem fins lucrativos com sede em Nova Iorque cujo objetivo consiste em elevar a prática do desenho de ruas e transportes internacionalmente.

OMS - Organizaçâo Mundial de Saúde OTTC - Operadora de Tecnologia de Transporte Credenciada PAITT - Plano de Açôes Imediatas de Transporte e Trânsito de Fortaleza PIN - Personal Identification Number (Número de Identificaçăo Pessoal) PSBC Urban Solutions - Public Bike System Company PNMU - Política Nacional de Mobilidade Urbana PNT - People Near Transit (Indicador de proximidade ao transporte de média e alta de capacidade)

RMSP - Regiăo Metropolitana de Săo Paulo

Semob - Secretaria Nacional de Mobilidade Urbana

SPBC - Sistema Público de Bicicleta Compartilhada, traduçăo do termo em inglês Public Bike Sharing (PBS)

SAC - Serviço de Atendimento ao Consumidor 
SALTUR - Empresa Salvador Turismo

SELURB - Secretaria Executiva de Licenciamento e Urbanismo do Recife

SEMOC - Secretaria de Mobilidade e Controle Urbano do Recife

SETUREL - Secretaria de Turismo e Lazer

SMT - Secretaria Municipal de Transporte

SMU - Secretaria Municipal de Urbanismo do Rio de Janeiro

SPTRANS - Sáo Paulo Transporte S.A

TCM - Tribunal de Contas do Município

TNM - Transporte Nâo Motorizado

TPU - Termo de Permissâo de Uso

TRANSALVADOR - Superintendência de Trânsito do Salvador

VDB - Viagem por Dia por Bicicleta

VDE - Viagem por Dia por Estaçấo

WRI - World Resources Institute (Instituto Mundial de Recursos, traduçâo nossa). O WRI é uma organizaçấo de pesquisa global que transforma grandes ideias em açấo na área de meio ambiente, oportunidade econômica e bem-estar humano.

WRI Brasil - O WRI Brasil que faz parte do WRI, tem o intuito de tornar as cidades mais segura, agradáveis e inclusivas, auxiliando governos na implementaçâo de projetos e políticas públicas nas áreas de segurança viária, desenvolvimento urbano, mobilidade, entre outros. 


\section{Sumário}

$\begin{array}{ll}\text { Introdução } & 31\end{array}$

1.

Bicicleta e o espaço público

1.1. Benefícios da bicicleta 38

1.2. Breve resumo do planejamento urbano 43

1.3. Planejamento urbano contemporâneo 48

1.3.1. Desenvolvimento Orientado ao Transporte Sustentável (DOTS) $\quad 48$

1.3.2. People Near Transit (PNT) 53

2.

Sistema Público de Bicicletas Compartilhadas - SPBC 61

2.1. História e evolução dos sistemas 64

2.2. Conceitos e características do SPBC 82

2.3. Planejamento de SPBC com estação 88

2.4. Outros modelos de compartilhamento 96

2.4.1. Sistema dockless 96

2.4.2. Bicicleta elétrica 110

2.4.3. Patinete elétrico dockless 114

2.5. Considerações 126

3.

SPBC no Brasil $\quad 129$

3.1. A bicicleta no contexto brasileiro 129

3.2. Dados da bicicleta 134

3.2.1. Diretrizes públicas voltadas à bicicleta 142 
3.2.2. Leis e decretos sobre infraestrutura cicloviária em São Paulo

3.2.3. Histórico do SPBC no Brasil

3.2.4. Participação do poder público

3.3. Bike Sampa

3.3.1. Regulamentação de SPBC em São Paulo 173

3.3.2. Projeto do novo Bike Sampa em 2018

3.3.3. Estação Bike - Empréstimo de longa duração 187

3.3.4. Análise quantitativa do Bike Sampa 197

3.4. Exemplo: Cidade do México-Ecobici 218

3.4.1. Comparação Bike Sampa e Ecobici 224

3.5. Outros operadores em São Paulo 234

3.6. Efeitos na mobilidade urbana de São Paulo 244

3.6.1. Contador de ciclistas da Avenida Brigadeiro Faria Lima 248

3.6.2. Contagem de ciclistas da Avenida Brigadeiro Faria Lima 252

3.6.3. Pesquisa com ciclistas paulistanos 265

3.7 Desafios do SPBC em São Paulo 271

4.

Disputa do espaço urbano $\quad 279$

4.1. Reclamações 288

4.2. Crises recentes na mobilidade das cidades 296

4.3. Urbanismo tático 300

4.4. Considerações finais $\quad 310$

Referências 



\section{Introdução}

A presente pesquisa investiga o sistema público de bicicletas compartilhadas como complemento da mobilidade urbana, com o intuito de analisar a contribuiçăo e a importância na concretizaçăo da bicicleta, como meio de transporte e elemento presente no cotidiano da paisagem.

Essa dissertaçăo tem, como objetivo central, avaliar os desafios para a consolidaçăo do sistema de bicicletas compartilhadas como mais um modal de transporte público viável, em grandes cidades, ao identificar o contexto em que a bicicleta surge como alternativa no cenário da mobilidade urbana.

Com o embasamento teórico, espera-se elucidar a seguinte questâo: qual a contribuiçăo do sistema público de bicicletas compartilhadas na disputa do espaço e na convivência entre os diversos modais? Abaixo săo listados objetivos intermediários:

_identificar a importância do sistema público de bicicletas compartilhadas na promoçấo e incentivo ao deslocamento ativo, quando permitem a consolidaçấo como alternativa de transporte na cidade;

relacionar a implantaçăo do modal de transporte com a atual disputa pelo espaço público, revelada pela resistência da maioria das pessoas em compartilhar o espaço do automóvel, tanto das faixas de rolamento, pelo crescimento da infraestrutura cicloviária, pela própria presença de mais bicicletas ao dividir a via, quanto nas faixas de estacionamento, com a ocupaçăo pelas estaçôes de bicicletas compartilhadas; 
_estudar as questóes logísticas específicas da implantaçăo do sistema público de bicicletas compartilhadas em Săo Paulo, ao confrontar o número de estaçôes e de bicicletas, a localizaçăo das estaçôes e área de cobertura, e sua comparaçăo com o número de viagens, assim como a análise do uso de dois eixos de ciclovias: da Avenida Brigadeiro Faria Lima e da Avenida Vergueiro, onde há contadores de ciclistas.

A Cidade de Sáo Paulo constitui excelente estudo de caso pelas seguintes razóes: maior conhecimento acumulado de suas experiências com o modal, por ter maior vivência da cidade e experiência do uso da bicicleta, como deslocamento diário por parte da autora; pela quantidade de bases e dados disponíveis da cidade e do sistema público de bicicletas compartilhadas Bike Sampa; pela dimensâo e complexidade da cidade, ao considerar as problemáticas da mobilidade urbana, da intermodalidade, do relevo, da infraestrutura cicloviária, entre outros.

O aumento do uso da bicicleta no eixo da Avenida Brigadeiro Faria Lima também instigou a presente pesquisa. A ciclovia no canteiro central conforma extenso eixo de quinze quilômetros paralelos à Marginal Pinheiros e à Linha Esmeralda da Companhia Paulista de Trens Metropolitanos (CPTM), ao destacar as Avenidas Dr. Gastăo Vidigal, Professor Fonseca Rodrigues, Pedroso de Morais, Brigadeiro Faria Lima, Funchal, Engenheiro Luis Carlos Berrini e Dr. Chucri Zaidan. Esta infraestrutura conecta importante polo de integraçăo modal, o Largo da Batata onde há a Estaçăo de Metrô Faria Lima da Linha Quatro Amarela, ao conjunto de edifícios corporativos que ocupam a regiâo da Avenida 
Presidente Juscelino Kubitschek, no bairro Vila Olímpia e da Avenida Eng. Luís Carlos Berrini.

A construçăo dessa ciclovia entre 2012 e 2016, a inauguraçâo do Bicicletário Largo da Batata em 2014, aliada à introduçăo do sistema público de bicicletas compartilhadas (primeira fase em 2012 e segunda fase em 2018), provocou aumento considerável do uso das bicicletas no eixo indicado em azul, no mapa 1. A Estaçăo de Metrô Faria Lima encontra-se em local estratégico para viabilizar a integraçăo modal com a bicicleta. A ciclovia mencionada como infraestrutura consolidada e segura, paralela à Linha Esmeralda da CPTM, surge como opçâo de deslocamento, tanto para as pessoas que costumavam finalizar a viagem diária ao integrar o metrô com o trem, quanto com o ônibus. 


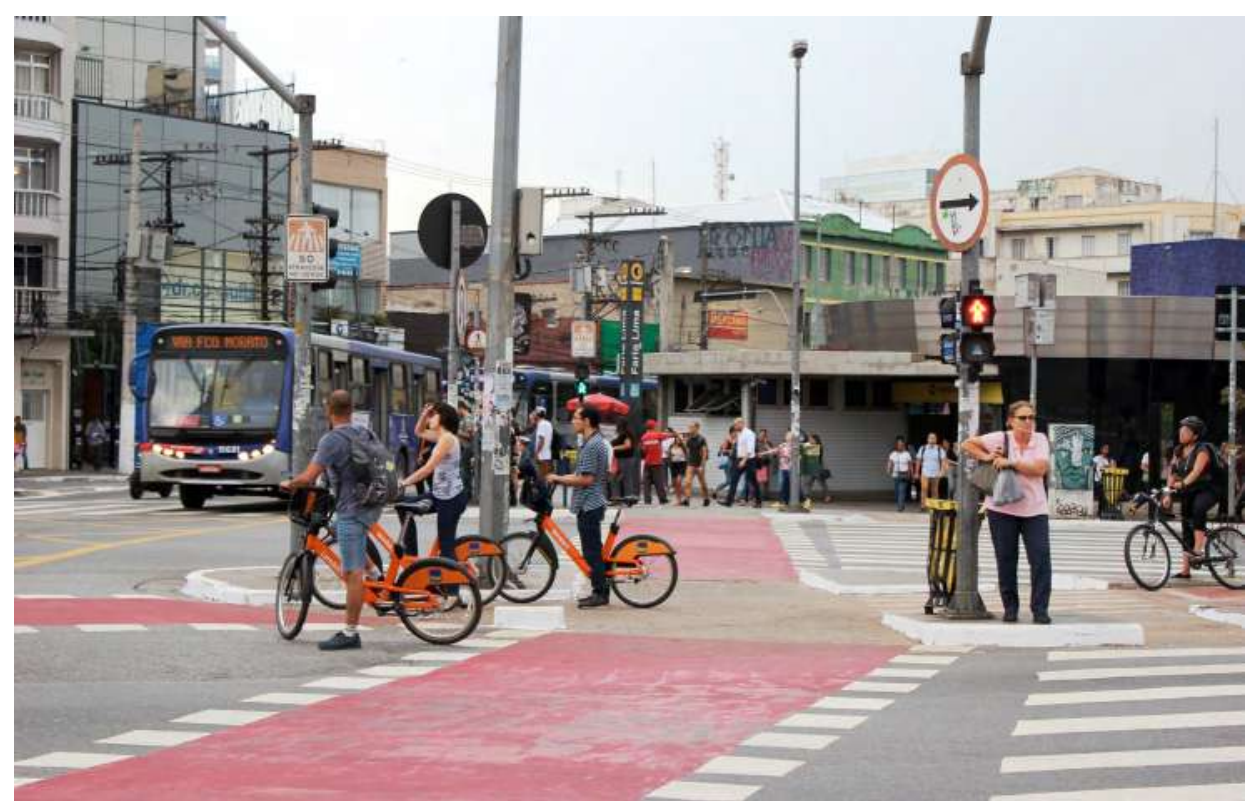

Foto 1 | Estação de Metrô Faria Lima e ciclovia da Faria Lima

Fonte: Luisa Cruz de Melo, em fevereiro de 2019.

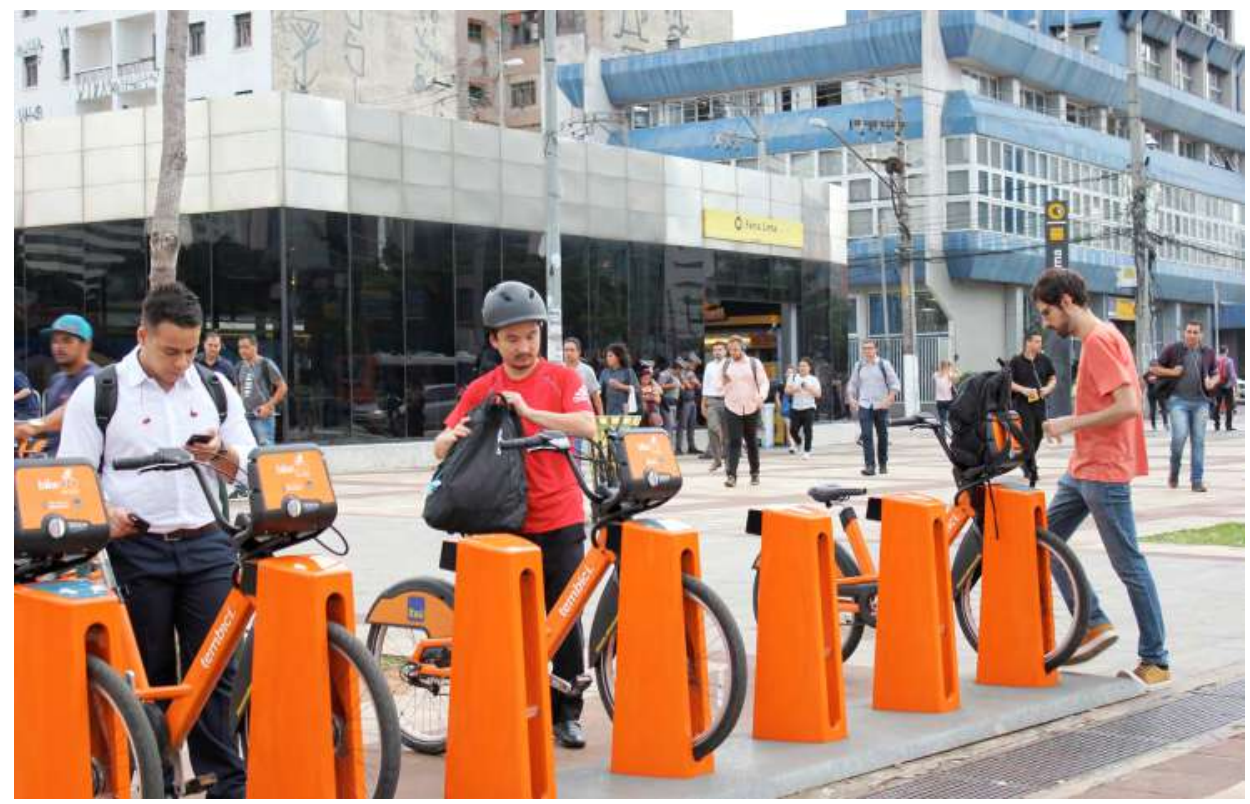

Foto 2 | Estação de Metrô Faria Lima e Estação 1 (Largo da Batata) do Bike Sampa Fonte: Luísa Cruz de Melo, em fevereiro de 2019. 

A importância da bicicleta no contexto urbano se deve em parte à acessibilidade e à facilidade de aquisiçăo e manutençâo para todas as classes sociais; à contribuiçấo para a melhora da saúde do usuário; ao baixo investimento em infraestrutura, quando comparado aos automóveis, ao viabilizar a implantaçâo nos mais diversos contextos urbanos.

A bicicleta nâo tem a pretensâo nem capacidade de resolver isoladamente o desafio da mobilidade urbana nas cidades brasileiras. Deve, contudo, constituir contribuiçâao importante no complemento às viagens diárias, principalmente nos primeiros e últimos quilômetros do trajeto, ao ampliar o alcance dos sistemas de maior capacidade existentes.

O futuro da mobilidade urbana năo está na bicicleta, no carro, no ônibus ou em qualquer modo de transporte, mas na integraçăo entre eles. Em inglês, a expressâo seamless mobility identifica um cenário de mobilidade em que as diferentes opçóes se complementam, em uma rede de transporte integrada e eficiente (PACHECO, 2017).

"O acesso a um sistema de transporte público eficiente pode transformar vidas" (MARQUES, 2015), pois o acesso ao transporte para a populaçăo de baixa renda que vive em regiôes periféricas pode significar oportunidades de emprego e menos tempo e dinheiro gastos nos deslocamentos cotidianos. $\mathrm{Na} 12^{\mathrm{a}}$ ediçấo da Pesquisa de Mobilidade Urbana, realizada pela Rede Nossa Sâo Paulo e pelo Ibope Inteligência, indica-se o tempo médio gasto de deslocamento em duas horas e 43 minutos (SILVA, 2018), o que demonstra a baixa qualidade do acesso ao transporte público para a maioria dos residentes do município, pelo tempo perdido diariamente no trânsito. 


\subsection{Benefícios da bicicleta}

A adoçăo da bicicleta como modo de deslocamento cotidiano contribui para a democratizaçăo do espaço público, visto que, por ser meio de transporte de baixo custo, proporciona ambiente urbano mais inclusivo, uma vez que o acesso aos seus serviços praticamente independe da renda do indivíduo (PAULA FILHO; SOUZA, 2016). Além de saudável, igualitário e sustentável, causa impacto positivo na segurança viária e na reduçâo de congestionamentos, e é bom para a economia. Alguns estudos recentes, segundo o Guia Global de Desenho de Ruas (NACTO, 2018), demontram que a ampliaçâo da acessibilidade de bicicletas aos centros comerciais das cidades atrai mais consumidores, ao gerar empregos e receitas.

Referente aos benefícios do uso da bicicleta nas cidades, Gehl (2013, p. 218) revela que:

O desenvolvimento de melhores condiçôes para caminhar e pedalar năo deve ser visto como medida temporária para a populaçăo mais pobre. Pelo contrário, é um investimento geral e pró-ativo na melhoria das condiçôes de vida e o desenvolvimento de sistemas sustentáveis de transporte para reduzir a poluiçăo e os riscos no tráfego, além de acomodar todos os grupos da sociedade.

Estudos recentes confirmam a poluiçăo do ar, como um dos grandes causadores das mortes nas cidades. O artigo do World Economic Forum, de Audrey de Nazelle (2018) questiona algumas tentativas para mitigar o problema, como incentivo aos veículos elétricos, e coloca a questăo de repensar o propósito das ruas: 
For example, what if we rethought the purpose of our streets. Are they really just meant for cars to get from $A$ to $B$ ? Or can we see them as a place to walk and cycle, where children play and neighbours meet? ${ }^{1}$ (NAZELLE, 2018).

O artigo da WRI Brasil (2018b) “Qual o impacto da poluiçăo do ar na saúde?” de 2018 também reforça o problema de se respirar o ar poluído nas cidades. O médico patologista Paulo Saldiva, professor da Faculdade de Medicina da USP, diz que o morador de Săo Paulo perde em média um ano e meio de vida devido à poluiçấo, e que equivale a fumar quatro cigarros por dia. $O$ texto analisa como a qualidade do ar é afetada pelos transportes, de acordo com o que foi documentado na greve dos caminhoneiros, ${ }^{2}$ em maio de 2018 . Na Cidade de Sâo Paulo, houve reduçâo de 50\% na poluiçâo do ar em um dos dias da paralisaçăo:

Ao optar pelo carro em vez do ônibus, uma pessoa contribui com 45 vezes mais emissóes de dióxido de carbono na atmosfera (gás que contribui para o aquecimento do planeta) e 30 vezes mais de monóxido de carbono (gás tóxico e poluente) (WRI BRASIL, 2018b).

Portanto, fica muito clara a importância na substituiçâo dos modais poluentes para a bicicleta, pois, além de năo poluir o meio ambiente e náo depender de fonte de energia năo renovável, é mais democrático por auxiliar

1 Por exemplo, e se nós repensássemos o propósito de nossas ruas. Eles são realmente destinados apenas para carros para ir de A para B? Ou podemos vê-los como um lugar para caminhar e pedalar, onde as crianças brincam e os vizinhos se encontram? (tradução nossa). 2 Greve dos caminhoneiros foi uma paralisação de caminhoneiros autônomos, com extensão nacional, de 21 a 30 de maio de 2018 . O bloqueio das rodovias causou indisponibilidade de alimentos, escassez e alta de preços da gasolina nas cidades afetadas. 
a promover a inclusăo social e ainda contribuir para que ocorram interaçóes cotidianas das pessoas:

\begin{abstract}
A bicicleta configura-se como elemento potencial a contribuir para a inclusăo social năo apenas por permitir acesso às funçôes da cidade (serviços básicos, cultura, melhores oportunidades de emprego) de forma autônoma e sem custo, mas também por favorecer o desenvolvimento do percurso. $O$ ato de caminhar e pedalar pela cidade reforça as trocas sociais, o contato dos cidadâos entre si e com a cidade, desenvolve o comércio de bairro e instiga a distribuiçâo das facilidades de forma mais equitativa (ROSA; SCHROEDER, 2014, p. 2, grifo nosso).
\end{abstract}

Ainda segundo os autores Rosa e Schroeder (2014), esse desenvolvimento do percurso é essencial por transformar locais de passagem em ambientes de convívio, sendo possível pelo contato visual decorrente daqueles que se locomovem por modos ativos com as fachadas dos edifícios e os espaços ao seu redor, ao promover a vivência de diversas experiências no trajeto, nâo apenas no binário origem e destino. Essa aproximaçăo do cidadāo ao contexto urbano em que se encontra inserido desenvolve o senso de localizaçăo, comunidade e pertencimento, e potencializa a transformaçăo de espaços, muitas vezes pouco utilizados.

Fabiano (2016) também discorre sobre a ocupaçăo da rua, e o papel da bicicleta na democratizaçâo do espaço público: 


\section{(...) a bicicleta tem um papel muito importante como indutor de inclusăo social, pois seu uso implica ocupar a rua e năo apenas}

trafegar, o que permite um contato maior com a cidade e com aquilo que ela oferece. Sendo assim a bicicleta como opçăo de transporte integrado a outros modos, representa nâo apenas vantagens ambientais e econômicas, mas também contribui com o avanço da cidade e da equidade social, além de democratizar o uso do espaço público (FABIANO, 2016, p. 10, grifo nosso).

No livro “Morte e Vida de Grandes Cidades” de 1961, Jane Jacobs (2011) reforça a ideia de que a cidade deve ser analisada no plano do pedestre, ao se considerarem as relaçôes cotidianas que acontecem no espaço. A segurança na via é baseada nos olhares das pessoas do bairro, e gera a confiança na rua que se forma com o tempo, a partir dos contatos públicos nas calçadas. “Aparentemente despretensiosos, despropositados e aleatórios, os contatos nas ruas constituem a pequena mudança a partir da qual pode florescer a vida pública exuberante da cidade" (JACOBS, 2011, p. 78).

Assim como o pedestre na cidade, o uso da bicicleta no cotidiano como meio de transporte possui forte influência nos empregos dos espaços e atualmente tem o poder de inspirar movimentos por novas formas de utilizaçăo das cidades (FRÚGOLI, 2016).

Sadik-khan e Solomonow (2016) explicam que a adoçăo de intervençōes em pequena escala de maneira rápida e barata podem redistribuir o espaço público e restaurar o equilíbrio da rua, normalmente determinado pelo planejamento voltado à prioridade dos automóveis, que ignoravam a experiência humana na via pública. "Roads are built for cars, and this 
combination stifles vital human behaviors like social interaction, physical activity, and spontaneity"3 (SADIK-KHAN; SOLOMONOW, 2016, p. 61).

As mobilidades ativas na cidade acarretam maior aproximaçâo dos cidadâos com as particularidades do espaço urbano, ao evidenciar a demanda existente de espaços de convivência de qualidade, em lugar de áreas reservadas para os automóveis. Pedestres e ciclistas reivindicam espaços tanto de passagem, como calçadas expandidas, calçadôes, cruzamentos mais seguros, tempo de travessias do pedestre, ciclovias e ciclofaixas, com potencialidade de se tornarem ambientes de estar e convívio, quanto de permanência, como vagas vivas (parklets), centro aberto e ruas abertas.

Esses movimentos demonstram a disputa pelo espaço público e a mobilidade ativa quando reconquistam espaços urbanos, com melhoria da segurança e qualidade de vida da populaçấo. Mais pessoas a caminhar e a pedalar pelas ruas da cidade promovem a sensaçấo de segurança e a atratividade desses locais.

A importância da convivência, dos encontros e da vida urbana, em texto do poder público municipal de Sâo Paulo, é descrita no relato a seguir:

O ambiente da cidade também afeta o período de permanência e a forma como as pessoas usam a cidade. Áreas públicas bonitas e convidativas com ambiente confortável, baixo nível de ruído e possibilidades de convivência criam condiçôes ideais para a vida urbana (PREFEITURA DE SÂO PAULO, 2015a, p. 46).

3 As ruas são construídas para os carros, e essa combinação sufoca comportamentos humanos vitais, como a interação social, a atividade física e a espontaneidade (tradução nossa). 
As políticas públicas atuais, tanto em âmbito nacional, quanto em municipal, por determinarem a prioridade aos modos ativos de deslocamento, além do transporte público, demonstram cenário favorável a essas mudanças; porém, ainda existem diferenças evidentes entre a legislaçăo e a prática; vários planos e obras federais, estaduais e municipais continuam a priorizar os automóveis. "A reversăo dessa hegemonia é lenta, pois envolve um longo processo de transformaçăo social, política e nos hábitos da populaçăo" (ROSA; SCHROEDER, 2014, p. 10).

Nesse contexto, aparece a ideia de mudança de paradigma, de difícil implementaçăo concreta, pela importância em liberar a grande maioria da dependência do automóvel, quando privilegia os transportes públicos, o uso da bicicleta e o andar a pé. Franco (2010, p. 152) define que “o sistema cicloviário, interligado aos outros meios de transporte, trará mudanças de comportamento por parte da populaçăo paulistana, importantes no sentido de resiliência urbana", ao evidenciar a importância da renovaçăo da cultura para o futuro dos deslocamentos urbanos.

\subsection{Breve resumo do planejamento urbano}

Segundo Rosa e Schroeder (2014, p.1), “o atual padrăo de mobilidade, centrado no automóvel, configurou-se como um dos principais elementos a influenciar a estrutura urbana das cidades brasileiras". Todos os conceitos e a construçâo de espaços da cidade foram baseados nessa hierarquia, na qual as mobilidades ativas, pedestres, ciclistas e outros modos, assumem papel secundário e coadjuvante no desenho e na priorizaçăo dos projetos e configuraçâo dos espaços livres urbanos. O carro continua sendo a principal 
determinante na configuraçâo das cidades brasileiras, ao reproduzir modelo de urbanizaçăo baseado na segregaçăo socioespacial.

Assim como os autores mencionados, Macedo também reflete a respeito das consequências do automóvel como prioridade no contexto urbano:

A paisagem urbana brasileira passa, durante a segunda metade do século $\mathrm{XX}$, por uma mudança radical, na medida em que o espaço urbano é estruturado em funçâo da adoçâo, como política pública, do veículo automotor, como modelo de transporte da populaçăo (MACEDO, 2012, p. 59).

Esse modelo, determinado por interesses econômicos e políticos, fortaleceuse e se legitimou a partir do urbanismo modernista dos anos de 1940-1950, com pensamentos de Le Corbusier, baseado em "torres no parque", com a questăo da dispersâo urbana preconizada por Ebenezer Howard, com a cidade jardim descentralizada e com as propostas de planejamento regional, do final do século XIX e início do século XX, de Lewis Mumford (CYMBALISTA, 2018).

O aumento da populaçâo nos centros urbanos, com a superlotaçâo nos cortiços, questâo de saneamento básico e poluiçâo da concentraçâo de indústrias do século XIX, suscitou o estudo do planejamento urbano para trazer soluçōes a esses problemas. Ebenezer Howard elaborou a ideia da Cidade-Jardim, para conter o crescimento de Londres e repovoar a zona rural, onde os pobres que viviam nos cortiços, poderiam voltar a viver em contato com a natureza (JACOBS, 2011). “Para Howard, a propriedade comunal da terra era o fundamento essencial de sua cidade-jardim" (HALL, 2016, p. 130). Seriam pequenas cidades autossuficientes, com cinturăo agrícola, indústria e moradia. Na mesma linha, o planejamento regional, pensado por Lewis Mumford, visava à 
distribuiçâo da populaçâo e dos serviços para evitar a concentraçâo nos centros das cidades e a destruiçấo das vantagens naturais do lugar.

Essas ideias foram adotadas na construçăo de subúrbios descentralizados; porém, descaracterizadas em sua essência, pelas realidades da economia capitalista e da sociedade pós-industrial; transformaram-se, em muitos casos, em cidades dormitórios, sem a conexăo entre a indústria e a terra e sem a vida cooperativa, ao sofrer dispersăo territorial mais ampla ainda com o uso do automóvel em larga escala (HALL, 2016).

Para Le Corbusier, era necessário "eliminar o excesso populacional dos centros de nossas cidades aumentado-lhes a densidade" (HALL, 2016, p. 293), com a melhora da circulaçăo (baseada nos automóveis) e aumento da quantidade de espaços livres. Por isso, acreditava na soluçăo trazida pelas altas torres de moradia que ocupam pouca área do terreno. Traz em seu discurso a reconstruçâo dos centros urbanos, a visăo geométrica do traçado da cidade e a segregaçấo de classe e de usos, todos igualmente coletivizados, ao reduzir ao mínimo o espaço individualizado. Cymbalista (2018, p. 39) reforça que a lógica modernista pregava o isolamento do edifício do tecido urbano, "tratando o espaço público como pano de fundo do edifício, bem como a do rodoviarismo e da lógica dos subúrbios".

Hall (2016) também reflete sobre o precursor da dispersăo em cidades europeias: a suburbanizaçâo ou o automóvel. No caso de Londres, afirma que o espalhamento suburbano aconteceu antes da massificaçăo do carro; no entanto, este permitiu que os subúrbios se dispersassem mais livremente e mais longe do que apenas com o transporte de massa. 
De acordo com Sadik-khan e Solomonow (2016), a maioria dos engenheiros urbanos no último século trabalharam com a diretriz de que a prioridade do transporte na cidade é o automóvel, e a vida urbana com pedestres, ciclistas e usuários do transporte público săo considerados estorvos à sua fluidez. Eles contam, a partir de estudos do historiador Peter Norton que, no início do século XX, a populaçăo assustada com a rapidez dos carros, os acidentes e o congestionamento que estes causavam nas ruas da cidade reivindicaram a adoçáo de limite de velocidade. A indústria automobilística, no entanto, reagiu ao problema, quando apontou os pedestres como os culpados pelas próprias casualidades, que eles deveriam se responsabilizar pela sua segurança, ao temer e ao evitar as ruas.

Assim como urbanistas modernistas, Robert Moses, oficial público durante muitos anos do século XX da Cidade de Nova Iorque, acreditava nas intervençôes urbanas de grande escala, com os projetos de revitalizaçâo urbana padronizados e idealizados, ao focar a priorizaçâo da fluidez dos automóveis e empreendimentos de uso monofuncional. Ele declarou "as cidades sâo criadas pelo e para o tráfego. Uma cidade sem tráfego é uma cidade morta ${ }^{4}$ (COHEN-SOLAL ${ }^{5}, 2010$ apud CYMBALISTA, 2018, p. 80).

Por volta dos anos 1960, Moses encontrou resistência nos pensamentos ativistas da jornalista Jane Jacobs, que defendia a cidade compacta, vibrante

4 Paulo Maluf, prefeito de São Paulo de 1993 a 1997, em reportagem da Folha de S. Paulo, em 1996, revelou: "Graças a Deus que tem engarrafamento. Bendito engarrafamento. Engarrafamento é sinal de progresso" e completou ao afirmar que o automóvel "dá status, dá liberdade".(GANCIA, 1996). Isso mostra como a priorização do automóvel é direcionada por interesses políticos.

5 COHEN-SOLAL, Annie. Leo and his circle: the life of Leo Castelli, New York: Alfred A. Knopf, 2010. 
e caminhável e é considerada uma das responsáveis pela origem da sensibilidade atual que valoriza os tecidos históricos, o papel social das ruas e calçadas, o uso misto e que combate a hegemonia dos carros (CYMBALISTA, 2018, p. 9).

Jacobs atacou tanto o movimento da cidade-jardim, por acreditarem que para salvar a cidade seria necessário abandonar a vida urbana a partir da descentralizaçăo, quanto o egotismo de Le Corbusier, por seu planejamento simbólico de cidades ordenadas, feito para automóveis, com traçados de vias expressas com poucos cruzamentos para năo atrapalhar o tráfego, ao manter os pedestres nos parques, longe das ruas (JACOBS, 2011).

A jornalista argumenta que as altas densidades populacionais urbanas năo representam problema para a cidade, desde que năo acarrete a superlotaçăo dos edifícios. Sua intençâo é a conservaçăo dos bairros da área central, a mistura de usos para garantir que as pessoas permaneçam nos locais em diferentes horas do dia, com densa concentraçâo de moradores e de serviços (HALL, 2016).

O desenvolvimento urbano predominante do século XX foi baseado na baixa densidade espalhada e orientada pelo automóvel e o resultado desastroso do modelo para a populaçăo e para o planeta é percebido atualmente. Além do congestionamento, acidentes e mortes de trânsito, a mobilidade baseada no automóvel contribui com a poluiçăo e a mudança climática, ao ameaçar a saúde da populaçăo urbana ao redor do mundo. 
O modelo que ainda estrutura o crescimento de nossas cidades reproduz a cultura urbanística de forma espraiada e dispersa, sem controle em seus limites de crescimento, segmentado ou setorizado, de baixa densidade populacional, que favorece a exclusáo social, a falta de controle, o impacto ambiental e, em geral, dificuldade de locomoçăo da populaçăo" (MINISTÉRIO DAS CIDADES, 2013, p. 25).

Há previsâo de crescimento da populaçâo urbana em 63\% até 2050, e se a tendência se mantiver, a área total urbana irá triplicar. Marks (2016, p. 5) afirma que as cidades irâo crescer, mas como se dará esse crescimento será fundamental para a sobrevivência do planeta. "We need to come together to fight sprawl and create inclusive, compact, people-oriented cities. We need to disrupt urban development as we know it and create a new paradigma for growth for our cities." ${ }^{\prime 6}$

\subsection{Planejamento urbano contemporâneo}

\subsubsection{Desenvolvimento Orientado ao Transporte Sustentável (DOTS)}

A bicicleta integrada na mobilidade urbana como alternativa real de transporte tem capacidade de contribuir para a transformaçăo dos padrôes de mobilidade da cidade, atestado pelas intervençōes recentes na infraestrutura cicloviária que ocorreram na Cidade de Săo Paulo (2012 a 2016), quando

6 Precisamos nos unir para lutar contra o espraiamento e criar cidades inclusivas, compactas e orientadas para as pessoas. Precisamos interromper o desenvolvimento urbano como conhecemos e criar novo paradigma para o crescimento de nossas cidades (tradução nossa). 
modificam a paisagem da cidade e a tornam mais inclusiva, por contribuir com o acesso ao transporte público.

A construçăo de ciclovias e ciclofaixas na cidade, aliada a outras infraestruturas para a bicicleta, como bicicletários e os Sistemas Públicos de Bicicletas Compartilhadas (SPBC), contribuem para a consolidaçâo do uso da bicicleta, por oferecer convite à integraçăo dos modais de transportes públicos com os modos ativos de deslocamento.

O DOTS consiste em modelo de planejamento urbano voltado ao transporte público que apresenta como objetivo o estímulo à ocupaçăo compacta e de alta densidade, com uso do solo misto e diversificado, quando oferece às pessoas serviços e espaços públicos seguros e atrativos, proporcionando a interaçăo social (DOTS CIDADES, 2015).

Esse direcionamento é muito diferente do padrăo atual de crescimento, como foi discutido anteriormente, de acordo com a ocupaçăo territorial distante, dispersa e desconectada. As áreas centrais dotadas de infraestrutura e serviços săo valorizadas e, portanto, mais caras, e afastam a populaçăo de baixa renda, que se instala em terras mais baratas com atendimento precário dos serviços essenciais. Nesse contexto, geram deslocamentos diários longos para acesso ao emprego e serviço, e afetam a qualidade de vida dessas pessoas, ao contribuir para a exclusăo social (DOTS CIDADES, 2015).

Os congestionamentos, além de gerar custo econômico em relaçăo ao gasto com combustível e ao tempo perdido de produçăo, ocasionam acidentes e mortes no trânsito. Segundo DOTS Cidades (2015, p. 9), a partir de dados do Departamento Nacional de Trânsito (DENATRAN, 2018), a proporçâo 
diminuiu de 7,4 hab/automóvel (2004) para 4,4 hab/automóvel (2014), com a duplicaçăo da frota de veículos de 38 milhóes em 2004 para 84 milhóes em 2014, ao acarretar o aumento da poluiçăo do ar das cidades.

Assim, a metodologia apresentada consiste em promover, com base nos sete elementos de um bairro DOTS (figura 1):

uma vida urbana completa com acesso adequado a toda a cidade, moradia de qualidade, mobilidade segura e agradável, suprimento das necessidades básicas, baixas emissōes de carbono, integraçáo social e geraçáo de emprego e cultura (DOTS CIDADES, 2015, p. 15. grifo do autor)

TRANSPORTE COLETIVO DE QUALIDADE

\$ Mobilidade não MOTORIZADA

GESTÃO DO USO DO AUTOMÓVEL

USO MISTO E EDIFÍCIOS EFICIENTES
CENTROS DE BAIRRO E PISOS TÉRREOS ATIVOS

ESPAÇOS PÚBLICOS E RECURSOS NATURAIS

(ii) PARTICIPAÇÃo E IDENTIDADE COMUNITÁRIA

Figura 1 | Sete elementos de um bairro DOTS

Fonte: DOTS CIDADES, 2015, p.16. 
O Instituto de Políticas de Transporte e Desenvolvimento (ITDP) desenvolveu o Padrăo de Qualidade DOTS, com a análise de oito princípios com o objetivo de definir o "desenvolvimento urbano que integre năo só o uso do solo com transporte, mas também as pessoas, atividades e oportunidades" (ITDP, 2017b, p. 4). Seus princípios apresentam o intuito de promover habitaçăo mais inclusiva, ruas seguras e valoriza os espaços públicos de lazer e parques, assim como serviços locais de saúde e educaçăo em todos os bairros.

É interessante observar que um dos objetivos presentes no princípio "compactar", a respeito do número de opçôes de transporte coletivo acessíveis a pé, encontra-se a indicaçăo de que um sistema denso de bicicletas compartilhadas ou públicas é considerado uma opçâo de transporte coletivo (ITDP, 2017b), ao ressaltar mais uma vez a importância de considerar o potencial da bicicleta como transporte na cidade. 


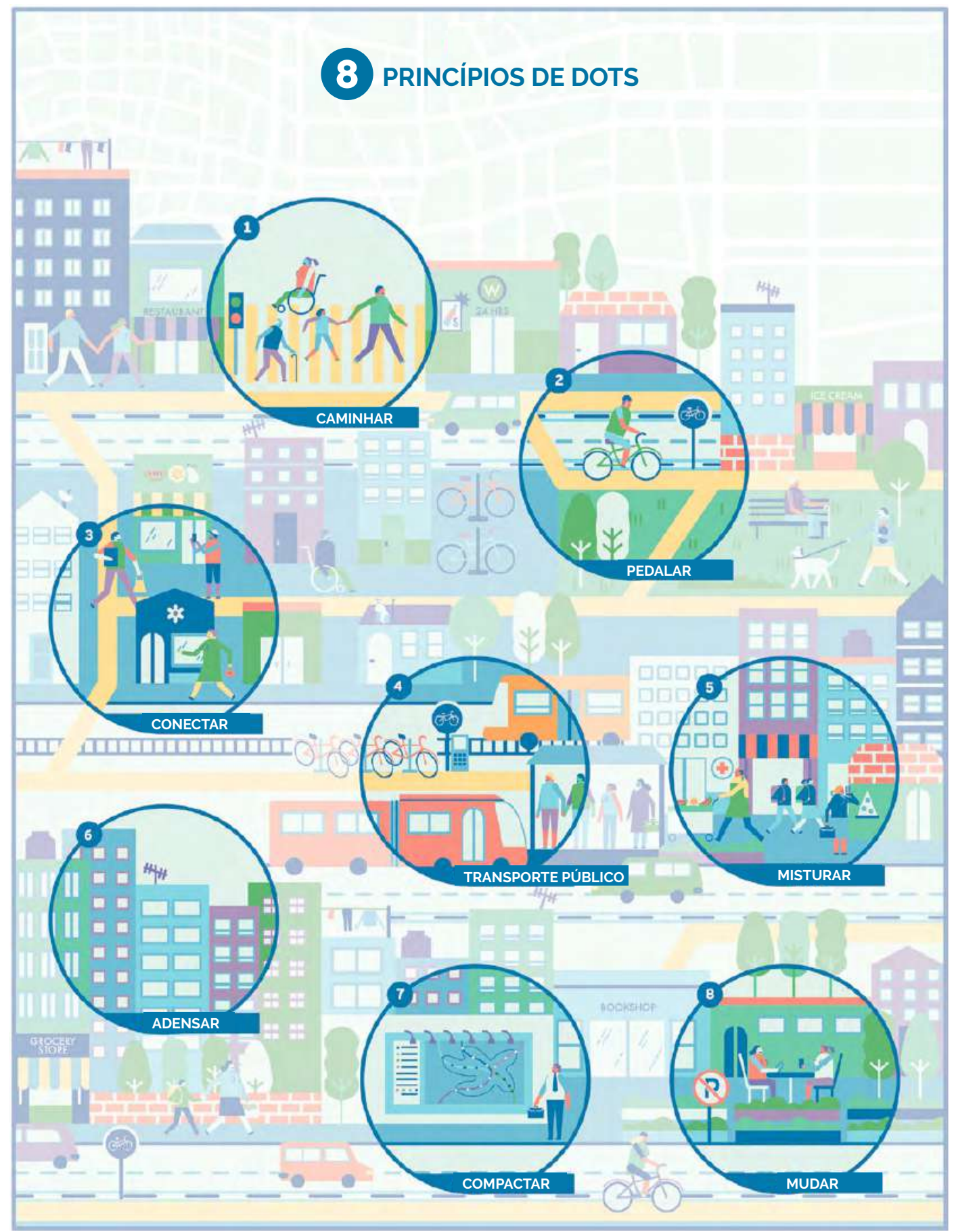

Figura 2 | Oito princípios de DOTS

Fonte: ITDP, 2017b, p.19. 


\subsubsection{People Near Transit (PNT) ${ }^{7}$}

A equipe técnica do ITDP desenvolveu o PNT, que representa a porcentagem de pessoas que vivem próximas às estaçóes de metrô, trem ou ao Transporte Rápido por Ônibus $\left(\mathrm{BRT}^{\mathrm{P}}\right)$, no raio de um quilômetro, e a corredores de ônibus, no raio de 500 metros, pois sâo distâncias facilmente percorridas a pé para o acesso a esses locais em um tempo de dez a quinze minutos. Além da distância, segundo os pesquisadores do ITDP, é importante considerar o fator da qualidade desse trajeto, como segurança, a presença de atrativos no percurso e infraestrutura cicloviária. Para que as pessoas estejam dispostas a reduzir o uso do automóvel, a opçăo do transporte público deve ser eficiente, vantajosa e confortável.

Sobre a qualidade do percurso, Schützer (2011) revela que as características da paisagem urbana influenciam o comportamento do pedestre, quanto à escolha pelo caminhar para realizaçăo de suas viagens, o que pode ser considerado para o uso da bicicleta, ao demonstrar o papel do desenho urbano no cotidiano das pessoas e na mobilidade urbana.

Se considerar o percurso feito de bicicleta, pode-se aumentar o raio para três quilômetros, nas proximidades das estaçôes de transporte público e para 1,5 quilômetros, desde corredores de ônibus, área prioritária para investimento de infraestrutura cicloviária, devido ao maior potencial de alimentaçáo dos sistemas de transporte coletivo. "Quanto maior for o acesso aos sistemas de alta capacidade, mais as cidades văo deixar para trás um modelo de

7 Indicador de proximidade ao transporte de média e alta capacidade.

8 BRT é a sigla em inglês do termo Bus Rapid Sistem. 
desenvolvimento urbano centrado no automóvel e, em contrapartida, se tornarăo mais sustentáveis." (MARQUES, 2015).

Características da localizaçăo săo utilizadas como recurso nos anúncios de empreendimentos imobiliários com a informaçâo da proximidade de estaçōes de metrô, áreas verdes e universidades, para sua valorizaçăo. A incorporadora e construtora Mitre Realty anuncia o empreendimento Haus Mitre Butantâ com a frase: “Você a poucos passos de toda Săo Paulo" ${ }^{9}$, e revela estar ao lado do Metrô Butantă. O papel da bicicleta nesse contexto é fundamental por ampliar a área atendida pelos transportes de média e alta capacidade e por democratizar o acesso.

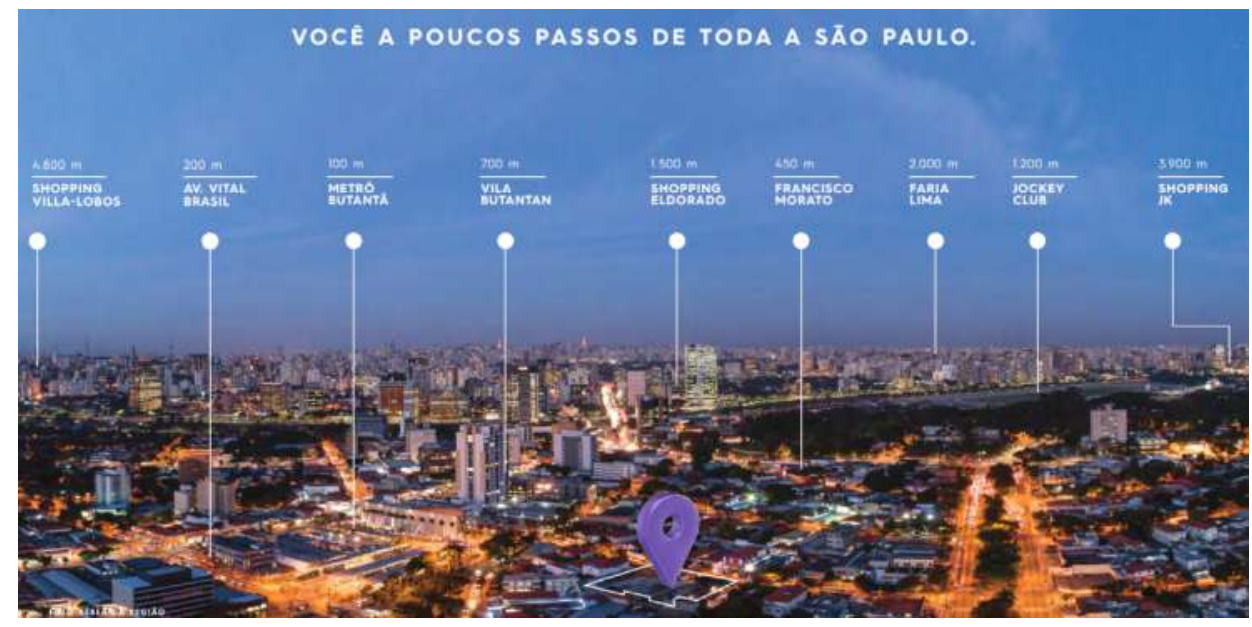

Figura 3 | Representação das distâncias no anúncio do empreendimento imobiliário Fonte: Site da Mitre Realty.

9 Site da Mitre Realty. Disponível em: <https://mitrerealty.com.br/empreendimentos/ hausmitrebutanta>. Acesso em: 15 jan. 2019. 
O WRI Brasil (2016), em parceria com ITDP Brasil, apresentou estudo sobre o PNT da Cidade de Sâo Paulo e descreveu que sem considerar a bicicleta, o PNT da cidade em 2015, ao consider apenas o acesso a pé ao transporte coletivo, era de apenas $25 \%$. Caso implementadas as metas já previstas no Plano Diretor Estratégico de Săo Paulo e no Programa de Corredores Metropolitanos, passaria, em 2025, ao índice de 70\%, como indicado na figura 5, próximo ao PNT de cidades que hoje possuem melhor infraestrutura de transporte de massa (figura 6).

A integraçâo da bicicleta com o transporte público é essencial por garantir acesso ao maior número de pessoas que passa a estar a uma distância acessível das estaçôes. 0 mesmo estudo identificou que a ampliaçăo da rede cicloviária poderia aumentar o indicador de $\mathbf{2 5 \%}$ para $\mathbf{7 4 \%}$, em 2015 e de $\mathbf{7 0 \%}$ para $\mathbf{9 7 \%}$, em 2025 .

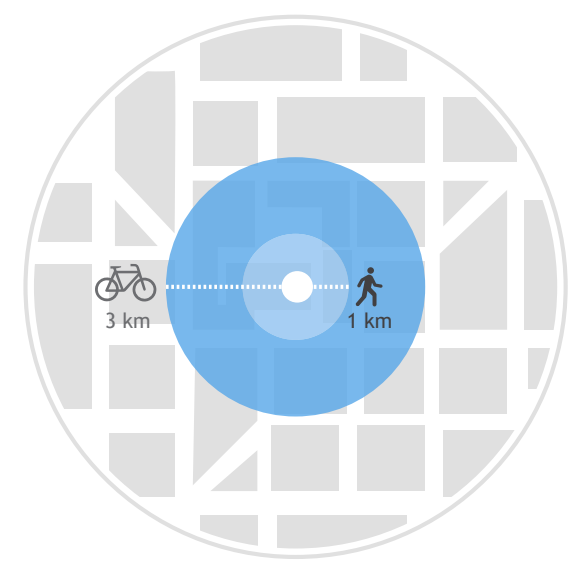

Figura 4 | Relação de acessibilidade da moradia a estações de transporte público entre pedestres e ciclistas Fonte: ITDP; WRI Brasil (2017). 

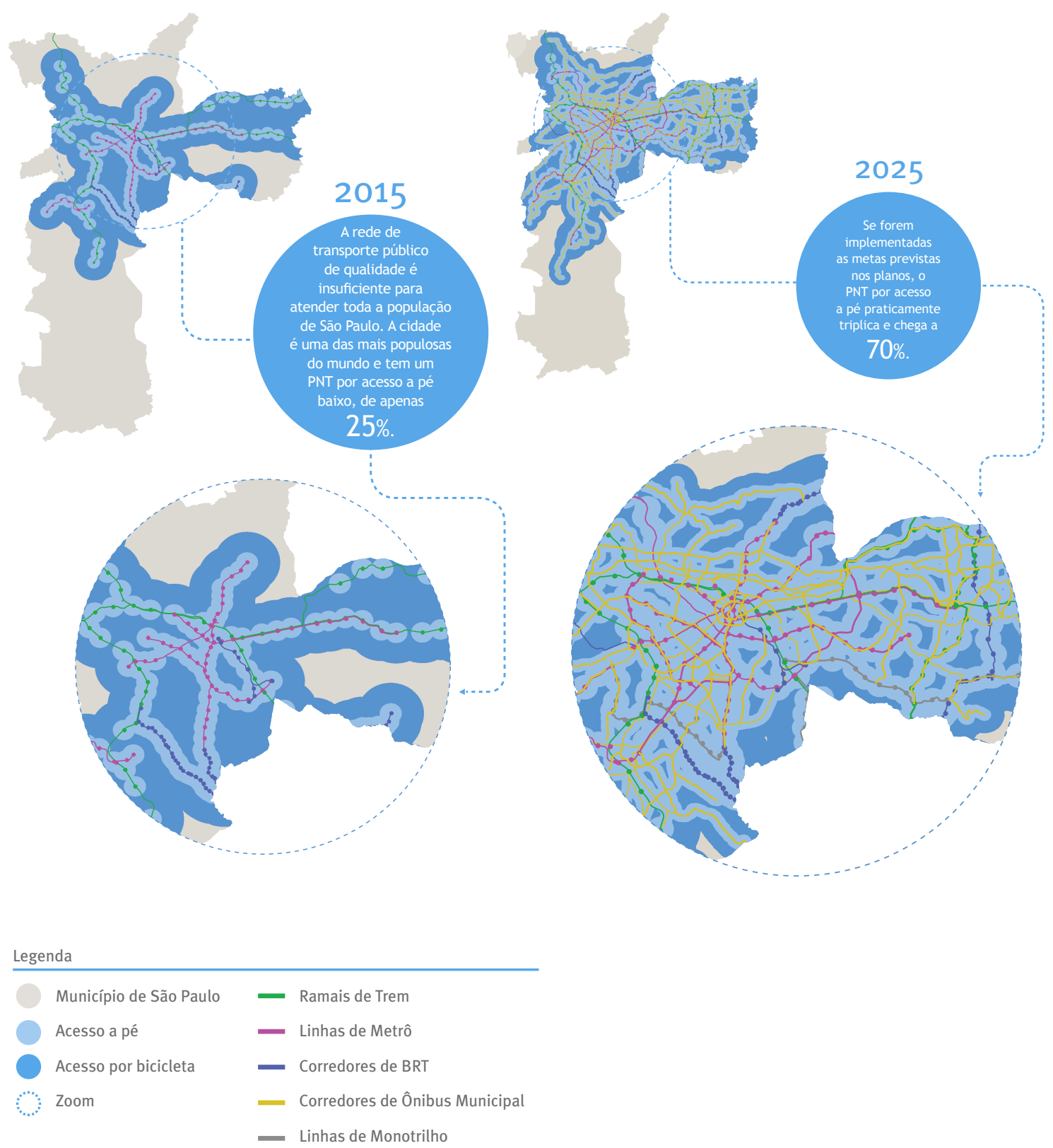

Figura 5 | PNT de São Paulo

Fonte: ITDP; WRI Brasil (2017). 


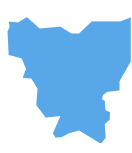

$44 \%$

Jacarta
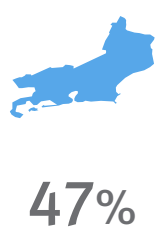

Rio de Janeiro

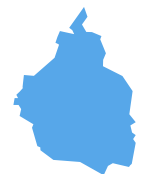

$48 \%$

Cidade do México

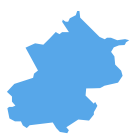

$60 \%$

Pequim

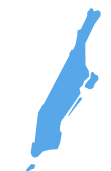

$77 \%$

Nova Iorque

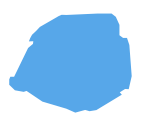

$100 \%$

Paris

Figura 6 | PNT por acesso a pé de outras cidades Fonte: ITDP; WRI Brasil (2017).

\begin{tabular}{|c|c|c|}
\hline Faixas de renda por salário minimo & $\mathbf{2 0 1 5}$ & $\mathbf{2 0 2 5}$ \\
\hline 0 a 0,5 & $18 \%$ & $61 \%$ \\
\hline 0,5 a 1 & $18 \%$ & $63 \%$ \\
\hline 1 a 3 & $24 \%$ & $70 \%$ \\
\hline mais de 3 & $40 \%$ & $87 \%$ \\
\hline
\end{tabular}

Tabela 1 | PNT separado por faixas de renda por salário mínimo da cidade de São Paulo Fonte: ITDP; WRI Brasil (2017).

Para a integraçăo da bicicleta nos sistemas de circulaçăo e transporte, é necessário contemplar a implantaçăo de infraestrutura cicloviária. A bicicleta apresenta o potencial de reduzir a desigualdade ao alcance do transporte público e contribui dessa forma para garantir acesso aos bens, serviços e empregos oferecidos na cidade: "assegurar o acesso ao transporte público é uma das formas de garantir o direito a uma cidade justa e sustentável" (ITDP; WRI BRASIL, 2017).

Para elevar o PNT da Cidade de Sáo Paulo, e reduzir, portanto, a desigualdade de acesso ao transporte público, o ITDP e o WRI Brasil (2017) revelam que os governos municipal e estadual devem focar seus esforços no DOT. As açôes devem objetivar: expansâo das redes de transporte público e de infraestrutura cicloviária, para garantir o acesso às pessoas que moram longe do centro da cidade; adensamento nas proximidades da rede de transporte, principalmente de regiōes menos ocupadas, com intuito de 
desenvolver novas centralidades e diminuir a necessidade de realizar longos deslocamentos; construçăo de habitaçăo de interesse social próxima ao transporte público, para que pessoas com baixa renda também tenham acesso às oportunidades do centro da cidade e promoçấo da integraçấo física, tarifária e operacional entre diferentes modos de transportes.

Apesar de a Regiâo Metropolitana de Sáo Paulo (mapa 2) apresentar a rede mais extensa de sistemas de transporte de média e alta capacidade do país, revelou um dos menores índices PNT, e demonstrou a baixa oferta de transporte já descrita. Segundo o ITDP Brasil (2017a):

Săo Paulo é uma cidade marcada por acentuado processo de espraiamento urbano e de verticalizaçăo das edificaçōes (adensamento construtivo), pouco orientado a infraestrutura de transporte público (especialmente sistemas de transporte de média e alta capacidade). Recentemente, o poder público da cidade de Sáo Paulo vem tentando reverter este padrấo, com a incorporaçăo de princípios de DOTS nas principais estratégias definidas pelo Plano Diretor Estratégico da cidade (2014).

É importante avaliar também o índice PNT vinculado à renda da populaçăo, para garantir a inclusăo social no contexto das políticas urbanas voltadas à promoçâo do DOTS. Na tabela 1, verifica-se que apenas $18 \%$ da populaçấo com renda até dois salários mínimos está próxima às estaçôes de transporte, e passa a 40\% quando a análise se limita à renda mais alta (em 2015). 


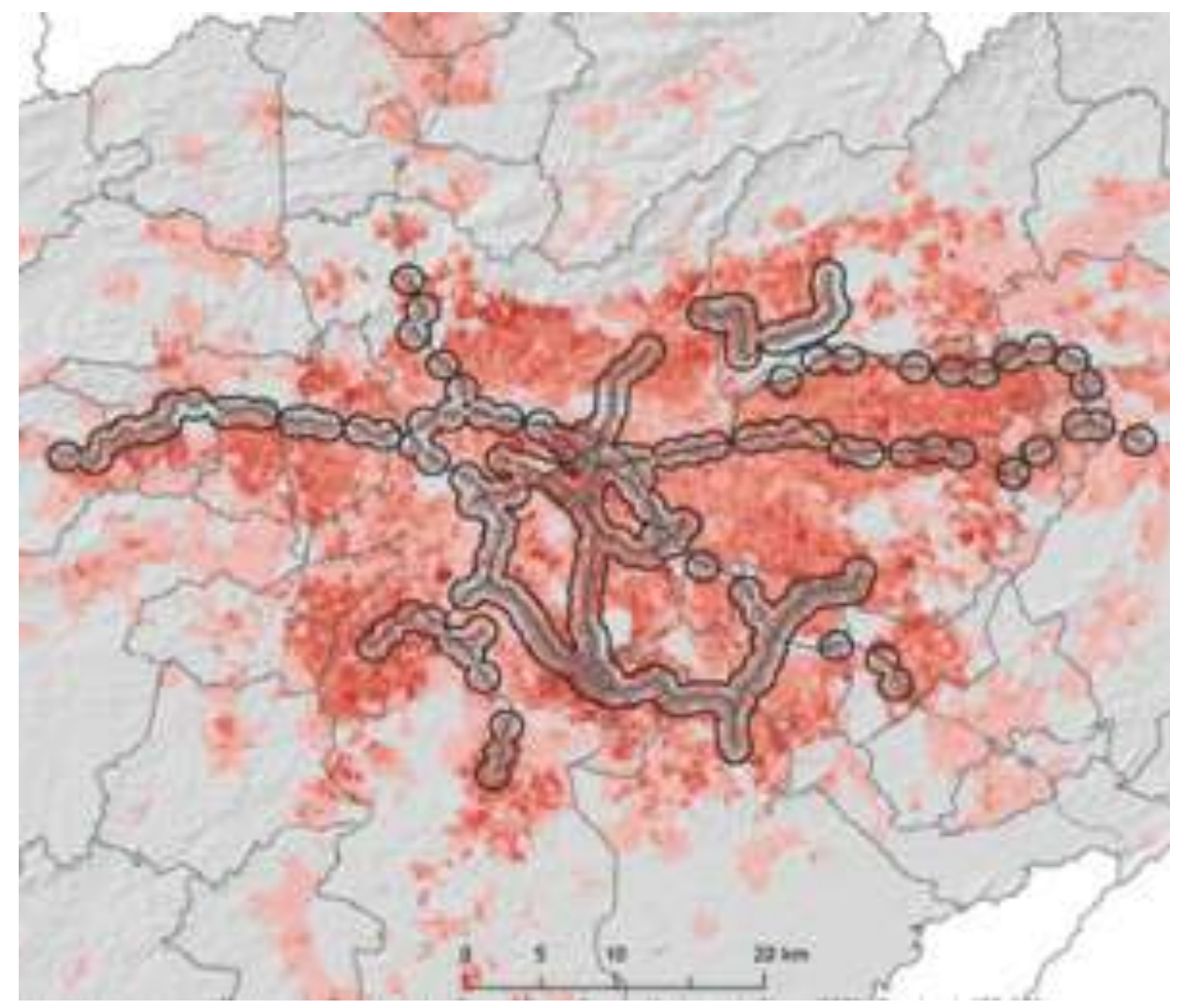

Mapa 2 | Áreas próximas ao sistema de transporte de alta e média capacidade da Região Metropolitana de São Paulo Fonte: ITDP Brasil (2017a).

Segundo Marks (2016), em artigo para o ITDP, atingir alto PNT é o primeiro e fundamental passo para realizar o Desenvolvimento Orientado pelo Transporte (DOT) que significa o desenvolvimento próximo a estaçôes de transporte público de modo compacto, com alta densidade, uso misto e caminhável.

A bicicleta tem o potencial de aumentar a abrangência deste índice, ao contribuir com a inclusâo social e melhora da qualidade de vida dessas pessoas. OSPBC caracteriza-se como uma das infraestruturas urbanas para o uso da bicicleta na cidade, ao propiciar o convite à experimentaçăo ao modo de deslocamento ativo. 



\section{2. \\ Sistema Público \\ de Bicicletas \\ Compartilhadas \\ - SPBC}

Nas últimas duas décadas, houve aumento acentuado do número de cidades com sistemas públicos de compartilhamento de bicicleta. Nos gráficos 1 e 2 , denota-se o surgimento de diversos SPBC no mundo, com alcance de dezoito milhǒes de bicicletas compartilhadas em maio de 2018.

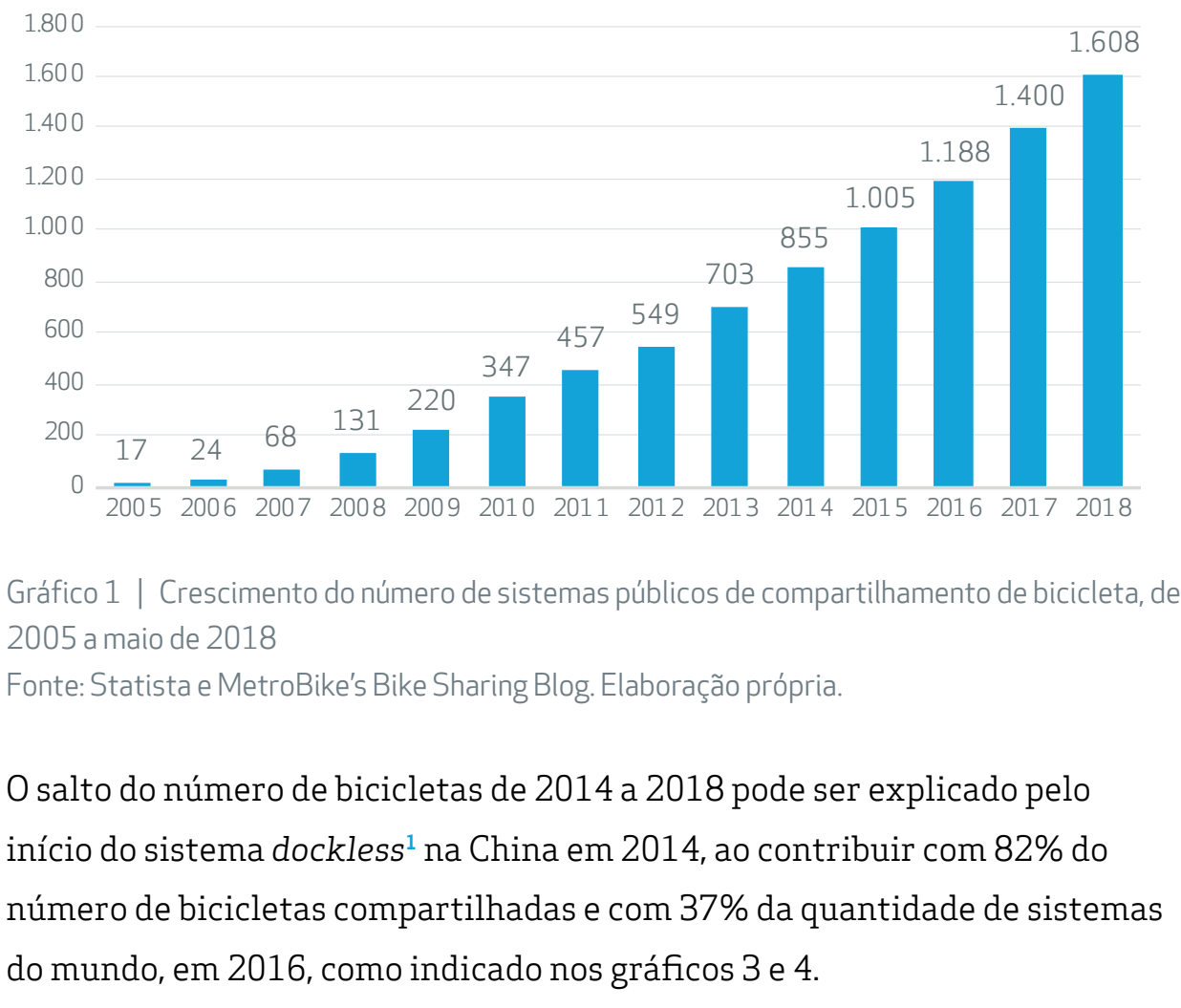

1 Sistema dockless significa sistema de bicicletas compartilhadas sem docas, ou seja, sem estações. 


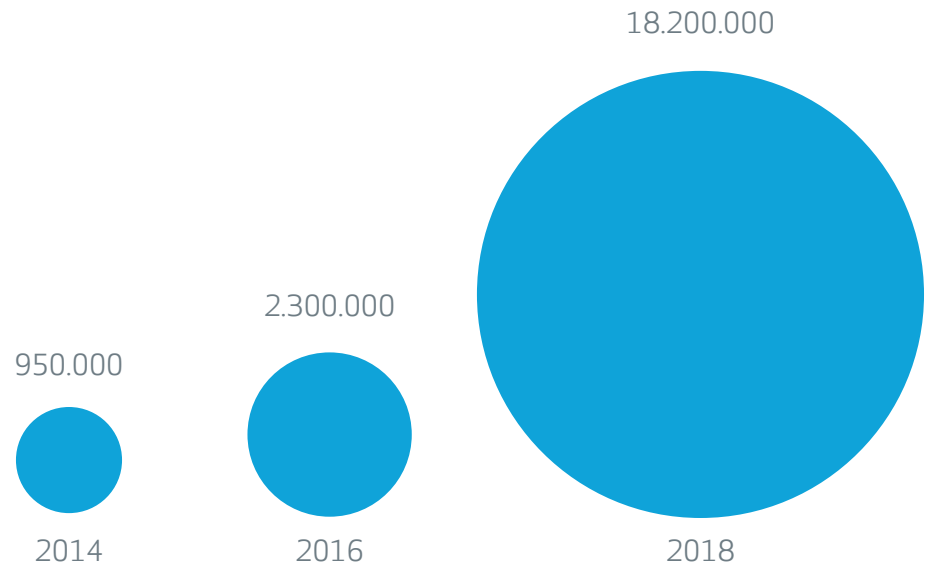

Gráfico 2 | Crescimento da frota de bicicletas compartilhadas, de 2014 a 2018 Fonte: Statista e MetroBike's Bike Sharing Blog. Elaboração própria.

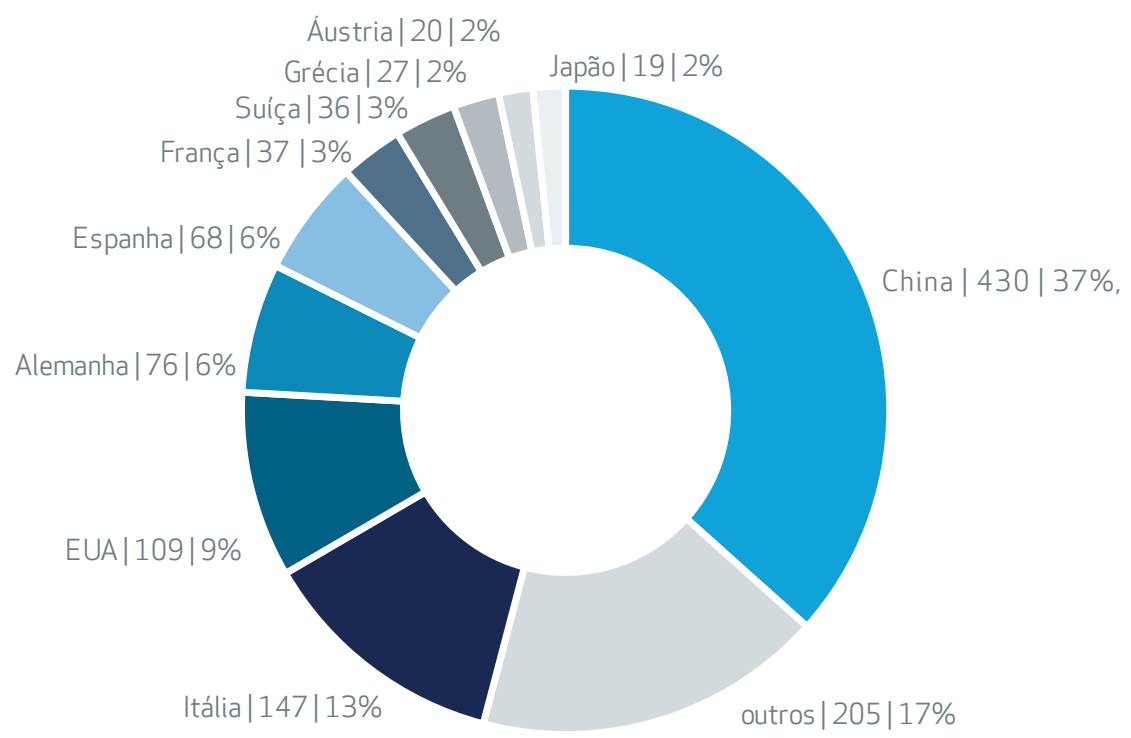

Gráfico 3 | Países com maior quantidade de SPBC, em 2016

Fonte: Russell Meddin em BikesharingMap. Elaboração própria. 


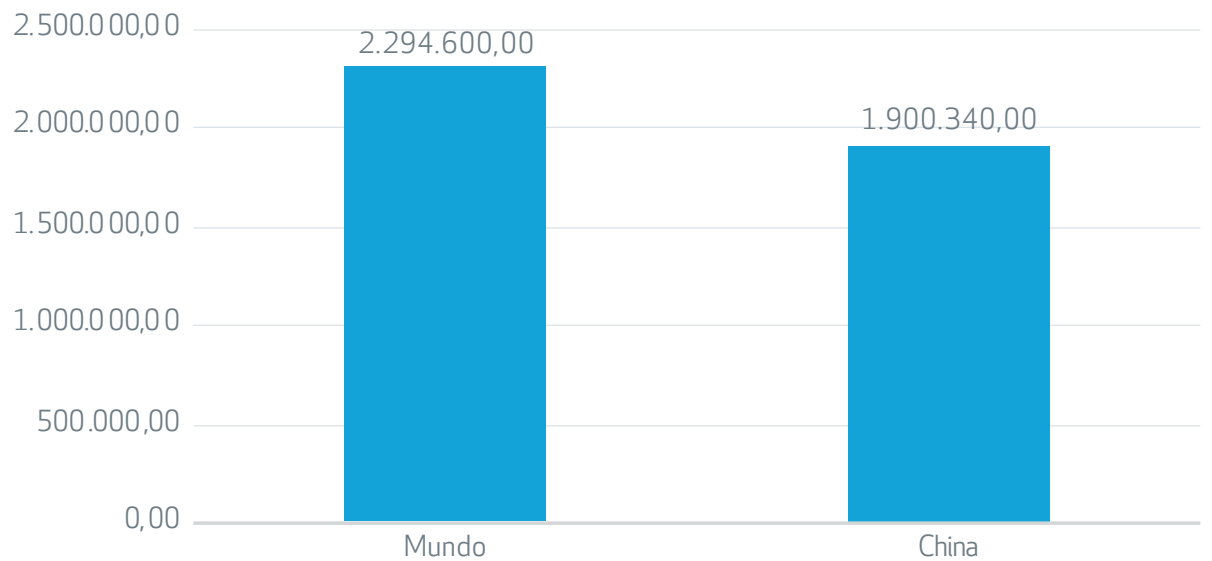

Gráfico 4 | Bicicletas compartilhadas no mundo e na China, em 2016 Fonte: Russell Meddin em BikesharingMap. Elaboração própria.

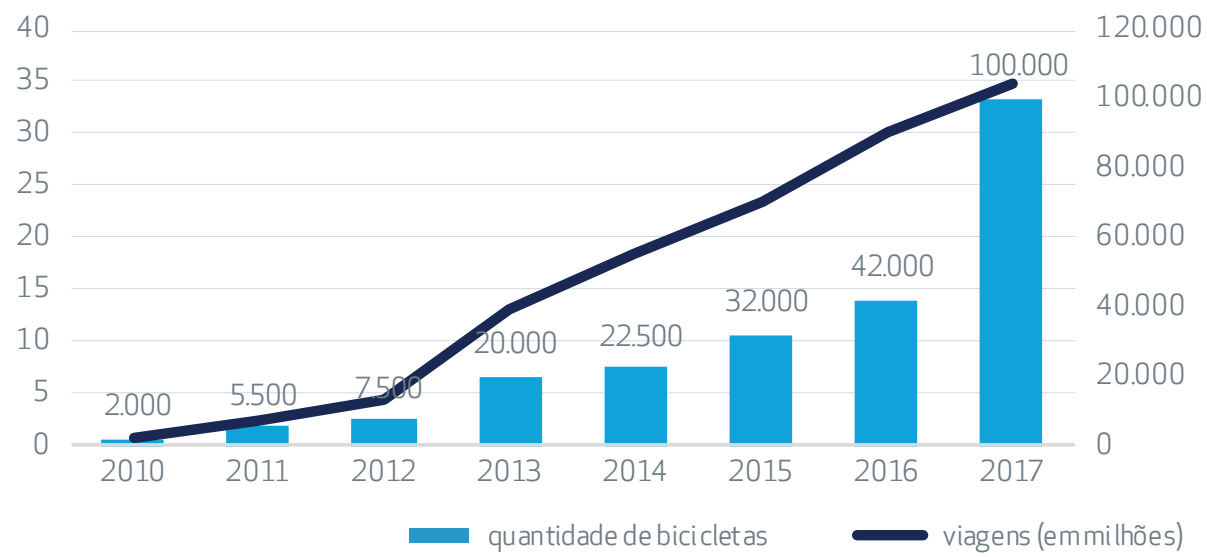

Gráfico 5 | Quantidade de bicicletas compartilhadas e viagens realizadas nos Estados Unidos de 2010 a 2017

Fonte: Nacto (2017) e Statista 2019. Elaboração própria.

O gráfico 5, por sua vez, revela a quantidade de bicicletas compartilhadas e o número de viagens realizadas nos sistemas dos Estados Unidos, país com priorizaçăo histórica do planejamento das cidades voltadas para o automóvel. 
Há diversas organizaçóes que estudam o tema, como a plataforma europeia Platform for European Bicycle Sharing \& Systems ${ }^{2}$ (PEBBS), a norte-americana North American Bikeshare Association ${ }^{3}$ (NABSA), The Bike-sharing World Map ${ }^{4}$, o Bike Share Map ${ }^{5}$, entre outros.

\subsection{História e evolução dos sistemas}

Nos últimos 50 anos, os SPBC passaram por três geraçōes diferentes, com características singulares, descritas a seguir.

\section{$1^{a}$ geração}

É interessante conhecer o contexto em que surgiu a ideia do primeiro modelo de compartilhamento de bicicletas.

Em 1965, o movimento holandês de anarquistas ativistas chamado Provos surgiu com o objetivo de reivindicar o direito de náo seguir os modelos de consumo. No primeiro momento com discursos antifumo, que pregavam sobre as péssimas consequências à saúde do cigarro, ao chegar ao movimento anticarro, e também focar nos efeitos para a poluiçâo do ar e para

2 Plataforma para o compartilhamento de bicicletas e sistemas europeus (tradução nossa).

3 Associação norte americana de bicicletas compartilhadas (tradução nossa).

4 O mapa mundial de bicicletas compartilhadas, com autoria de Russell Meddin. Disponível em: <www.bikesharingmap.com>. Acesso em: 19 jan. 2019.

50 mapa de bicicletas compartilhadas em tempo real. Disponivel em: <http://bikes.oobrien. com>. Acesso em: 19 jan. 2019. 
segurança das pessoas nas ruas. Nos anos 1960, fazer oposiçăo ao automóvel era inédito, por ir contra o que era (e ainda é) considerado o progresso.

\begin{abstract}
“(os motoristas) sâo consumidores hidrocarburodependentes, mimados pela indústria do petróleo: as companhias petrolíferas, que criam e moldam governos, estilos de vida, espaços urbanos e paisagens geográficas conforme suas necessidades. As companhias petrolíferas e os hidrocarburodependentes estâo empenhados em criar um mundo em que ir ao trabalho, à escola, fazer compras ou divertir-se sem sentar a bunda num automóvel e sem deixar uma pequena oferta em dinheiro à indústria se tornará impossível. Os motoristas utilizam um meio de transporte socialmente irresponsável e irracionalmente legal, que todo ano lança na atmosfera uma quantidade de substâncias poluentes equivalente a seu peso. Em 1965, uma estatística revelava que 74,1\% das vítimas de acidentes de automóvel eram pedestres, "sacrificados em nome do Santo Automóvel" (GUARNACCIA, 2010, p. 74).
\end{abstract}

Luud Schimmelpenninck, outro experimentador dos happenings ${ }^{6}$ antifumo de Provos, foi idealizador do Plano Branco (Witte Fietsenplan - White bicycle plan). Caracterizava-se pela disponibilizaçâo de bicicletas comuns, pintadas de branco, para o uso público geral. Qualquer pessoa poderia encontrar uma bicicleta, utilizá-la para ir até o local do destino e deixá-la para o próximo usuário (DeMaio, 2009). O branco, que passou a ser a cor oficial de Provos, foi escolhida porque suas açōes costumavam acontecer à noite, sendo assim mais visíveis (GUARNACCIA, 2010).

6 O happening nasceu em 1959, nos Estados Unidos, quando o artista Allan Kaprow levou suas obras para o lado de fora do museu, e percebeu que o que estava fazendo na realidade eram ambientes que deveriam ser vividos e não obras de arte, e onde a interação das atividades e os expectadores é o mais importante. 
De acordo com Zee (2016), no artigo publicado no The Guardian, esta açâo de Provos era a resposta às condiçôes da poluiçâo do ar e do excesso de consumismo da sociedade: "It polluted the air and children couldn't safely play in the streets any more"7.

Abaixo, a imagem e em seguida a traduçăo do plano descrito no Folheto de Provocaçāo (Provokatie) número 5 de Provos:

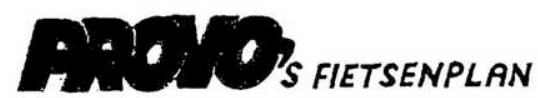

AMSTERDAMMERS:

DE ASFALTTEROEUR VIN OE GEMUTORISEERDE BOURGEOISIE

HEEFT LANG GENJEG EEDUUYO. DAGELYKS WORDEN MENSEN-

OFFERS GEBRACHT VOOR DE NIEUWSTE AUTORITEIT WAAR-

AAN HET KLOOTJESVOUK ZICH HEEFT OVERGELEVERD: OE

MUTO-AUTORITEIT. DE VERSTIKKENOE KOOLMONOXYOE IS ZYN

WIEROOK, ZYN BEELTENIS VERPEST IN OUIZENDVOUD

GRACHTEN EN STRATEN.

PROYO'S FIETSENPLAN BRENGT BEVRYOING VAN HET

AUTO-MONSTER. PROVO LANCEERT DE

WIITUE FHISTS, IN OPENBAAR BEZIT.

DE EERSTE WTWE :IISS WORDT/IS WOENSDAG 28 JULI

OM 3 UUR 'S MIDDAGS AAN PUBLIEK EN PERS AANGE-

BODEN BY HET AMSTERDAMS LIEVERDJE OP HET SPUI,

DE VERSLAAFDE CONSUMENT. $Q$

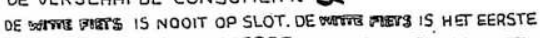

GRATIS, GEKOLLEKTIVISEERDE VERVOERMIDOEL. DE

MITrS IS EEN PROVOKATIE VAN HET KAPITALISTTES PRIVÉ-

BEZIT ; WANT

DE WOTIS F月ISTS IS ANARCHISTIES.

DE IATME अITTS KAM GEBRUIKT WORDEN DOOR WIE HEM

NODIG HEEFT EN MOET ONBEHEERO WEER ACHTERGE-

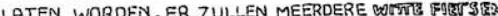

KOMEN TOT IEDER VAN HET WITTE VERVOER GEGRUIK

KFN. MAKEN EN HET AUTOGEVAAR GEWEKEN IS.

OE WATUE FIITS SIMBOLISEERT EENVOUD EN HYGIENE

TEGENOVER DE PROTSERIGHEIO EN VUILHEIO VAN DE

AUTORITAIRE AUTO.IMMERS EEN

\section{FITS IS ITS, MAAR BYWA NIETS!}

Figura 7 | Provocação n5: o plano da bicicleta branca

Fonte: KOOPS (2016): people.umass.edu

7 [Os automóveis] poluíam o ar e as crianças não podiam brincar de maneira segura mais nas ruas (tradução nossa). 
Plano das Bicicletas Brancas (Provocaçăo n5)

Cidadăos de Amsterdam!

Basta com o asfáltico terror da classe média motorizada! Todo dia, as massas oferecem novas vítimas em sacrifício ao último patrăo a quem se dobraram: a auto-ridade. O sufocante monóxido de carbono é seu incenso. A visăo de milhares de automóveis infecta ruas e canais.

O Plano Provo das bicicletas nos libertará desse monstro. Provo lança a bicicleta branca de propriedade comum. A primeira bicicleta branca será apresentada ao público quarta-feira, 28 de julho, às três da tarde no Lieverdje, o monumento do consumismo que nos torna escravos.

A bicicleta branca está sempre aberta. A bicicleta branca é o primeiro meio de transporte coletivo gratuito. A bicicleta branca é uma provocaçâo contra a propriedade capitalista, porque a bicicleta branca é anarquista. A bicicleta branca está à disposiçăo de quem quer que dela necessite. Uma vez utilizada, nós a deixamos para o usuário seguinte. As bicicletas brancas aumentarăo em número até que haja bicicletas suficientes para todos, e o transporte branco fará desaparecer a ameaça automobilística. A bicicleta branca simboliza simplicidade e higiene diante da cafonice e da sujeira do automóvel. Uma bicicleta branca năo é nada, mas já é alguma coisa (GUARNACCIA, 2010, p. 76). 
Luud Schimmelpenninck, em agosto de 1965, apresentou versăo mais técnica do plano direcionada à prefeitura:

(...) É, portanto, absolutamente necessário que o centro de Amsterdam seja fechado ao tráfego de veículos. A eliminaçăo do trânsito melhorará automaticamente o fluxo do transporte público em 40\%. Mantendo o mesmo número de bondes e de funcionários da companhia de transportes, será possível poupar dois milhóes de florins por ano. Propomos que a prefeitura adquira 20 mil bicicletas brancas ao ano (custo: um milhăo de florins), como integraçăo do transporte público. Tais bicicletas brancas pertencerâo a todos e a ninguém. Desse modo, o problema do trânsito no centro da cidade poderá ser resolvido ao cabo de poucos anos. Como primeiro passo para alcançar a cota de $20 \mathrm{mil}$ bicicletas brancas ao ano, Provo oferece aos voluntários a oportunidade de ter as próprias bicicletas pintadas de branco, apresentando-se à meia-noite em ponto diante da estátua do Moleque ba Spui.

Os táxis e os meios de transporte de utilidade pública terăo de funcionar com motores elétricos e alcançarăo a velocidade máxima de 40 quilômetros por hora.

Os motoristas deverâo deixar o próprio carro em casa e ir à cidade de trem, ou estacionar em espaços especialmente construídos nos limites da cidade tomando em seguida algum meio de transporte público. (...)

O AUTOMÓVEL é um meio de transporte que só se pode admitir em zonas escassamente habitadas. Os automóveis săo meios de transporte perigosos e totalmente inapropriados para a cidade. (...)

NÂO AO TRÂNISTO MOTORIZADO

SIM ÀS BICICLETAS BRANCAS (GUARNACCIA, 2010, p. 77-78). 
Aparece nesse discurso a ideia de adotar o uso do carro apenas para situaçōes em que é de fato necessário, ao pensar em formas eficientes, năo poluentes e seguras de deslocamentos no centro das cidades.

De acordo com ITDP (2014), foram distribuídas cinquenta bicicletas brancas para uso gratuito em toda a cidade; entretanto, estas foram apreendidas pela polícia local com o argumento de que por năo estarem trancadas, incitavam ao roubo. “Numa sociedade em que vigora a propriedade privada, o que é oferecido gratuitamente se torna ilegal e antissocial" (GUARNACCIA, 2010, p. 87).

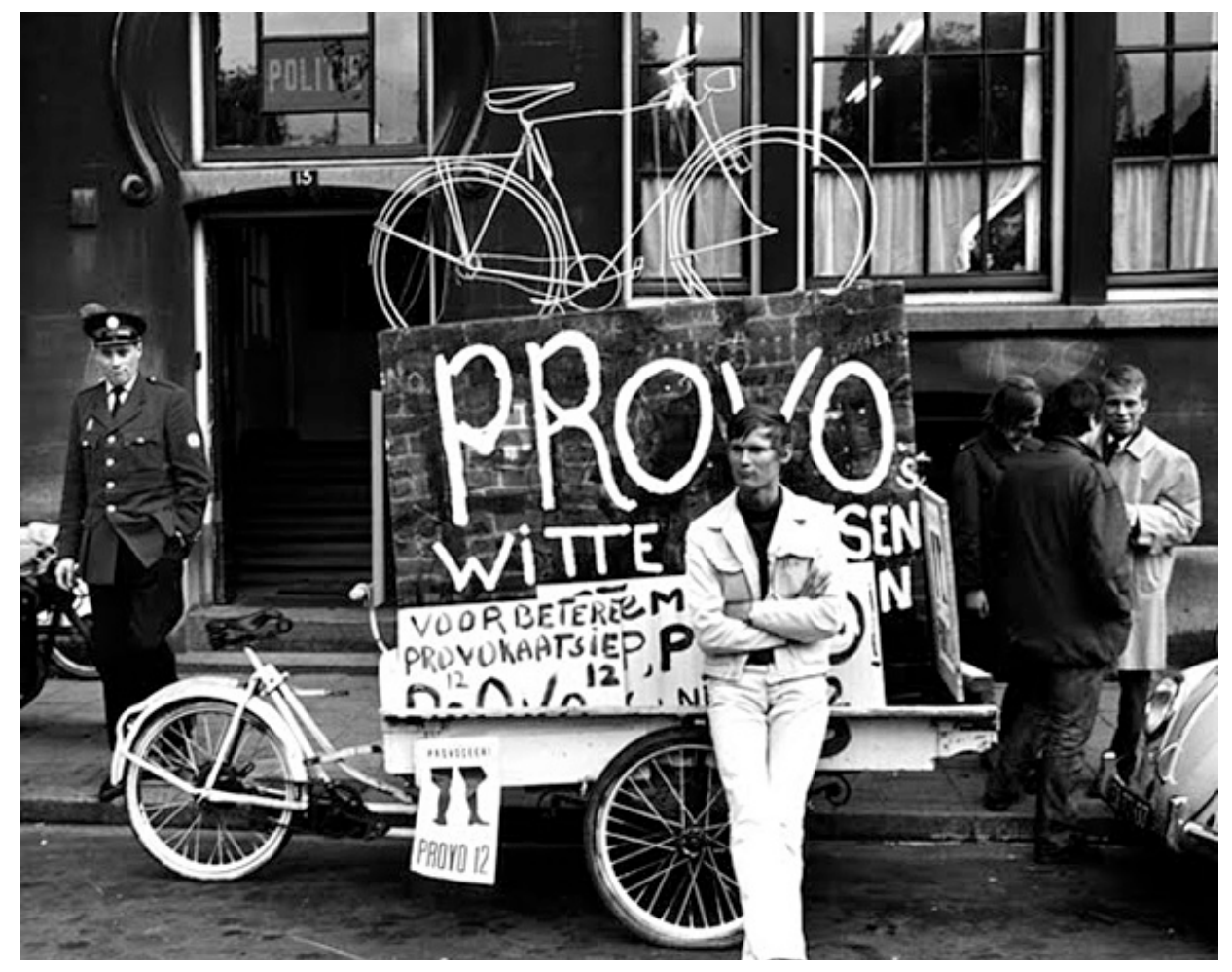

Foto 3 | Provos

Fonte: Cor Jaring. 


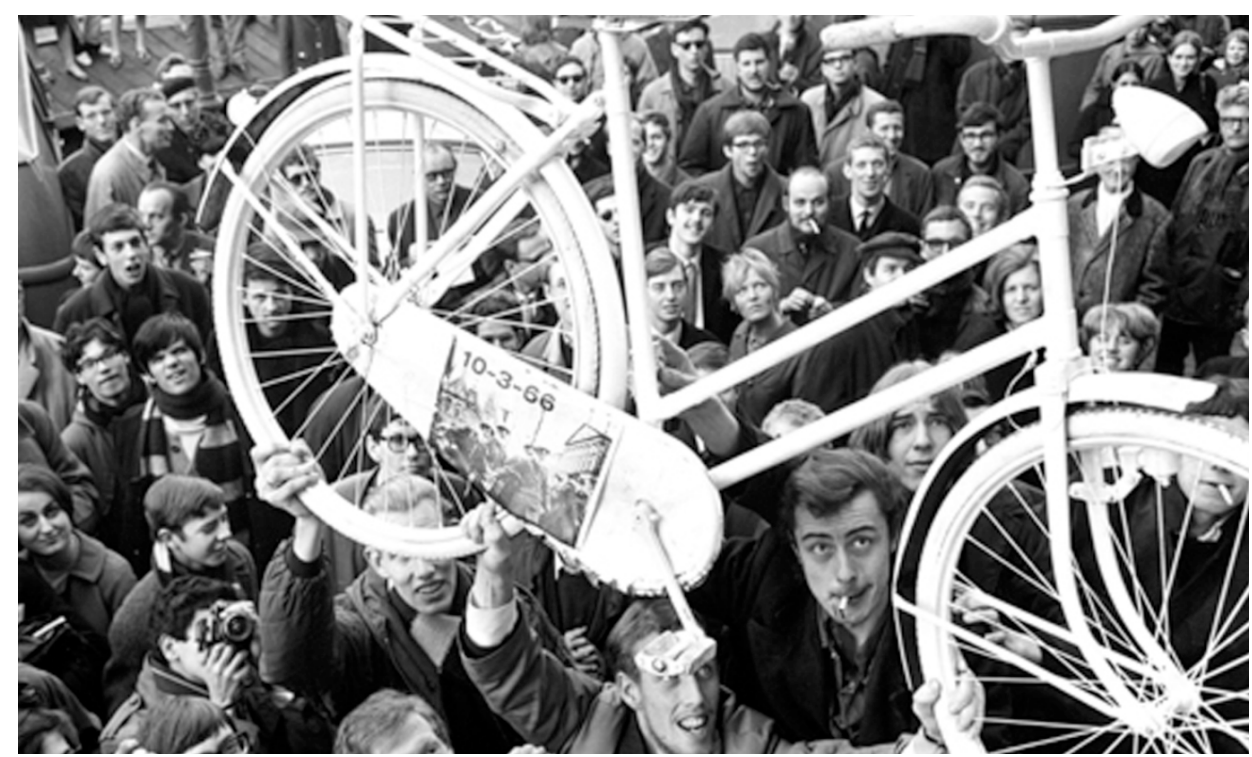

Foto 4 | Plano da bicicleta branca

Fonte: Cor Jaring.

Segundo DeMaio (2009), o projeto năo funcionou, pois as bicicletas foram jogadas nos canais ou apropriadas para uso particular e o programa colapsou em poucos dias. Zee (2016) descreve que as bicicletas foram removidas pela polícia, por desaprovaçăo das atividades de Provos.

O surgimento do conceito de compartilhamento de bicicleta pelo Provos, o grupo anarquista que confronta o consumismo e coloca a bicicleta branca em seu texto como provocaçâo da propriedade privada capitalista, remetenos à comparaçăo aos pensamentos de John Holloway, quando escreve sobre a necessidade de superaçăo do modo de produçăo capitalista. “(...) o funcionamento do mercado capitalista năo nos permite sobreviver, o que nos leva a procurar outras formas de viver, formas de solidariedade e cooperaçăo" (HOLLOWAY, 2013, p. 7). 
Superaçăo essa que năo seria feita pela destruiçăo do sistema capitalista, e sim, por fissuras no modelo: “as revoltas minúsculas, subterrâneas, podem ser muito mais radicais em seu potencial do que a mais barulhenta manifestaçăo" (HOLLOWAY, 2013, p. 79).

Quando Schimmelpenninck, idealizador do Plano das Bicicletas Brancas em 1965, tornou-se membro da Câmara Municipal dois anos depois, apresentou seu projeto, que consistia na distribuiçăo pela Municipalidade de Amsterdam, de maneira gratuita, de 10.000 bicicletas brancas pela cidade para usufruto público.

Tanto ITDP (2014) quanto Zee (2016) afirmam que a proposta foi rejeitada pela Assembleia Municipal. O argumento apresentado foi: "They said that the bicycle belongs to the past. They saw a glorious future for the car"8.

Apenas em 1975, o sistema de bicicletas brancas foi de fato introduzido com sucesso em Amsterdan; contudo, dentro do Parque Nacional de Hoge Veluwe, onde o risco de roubo era quase inexistente. Além disso, as bicicletas eram facilmente reconhecidas, pois nâo foram utilizadas modelos comuns, conforme descrito por Koops (2016) e funcionam até hoje.

8 Eles disseram que a bicicleta pertencia ao passado. Eles enxergavam o futuro glorioso do automóvel (tradução nossa). 


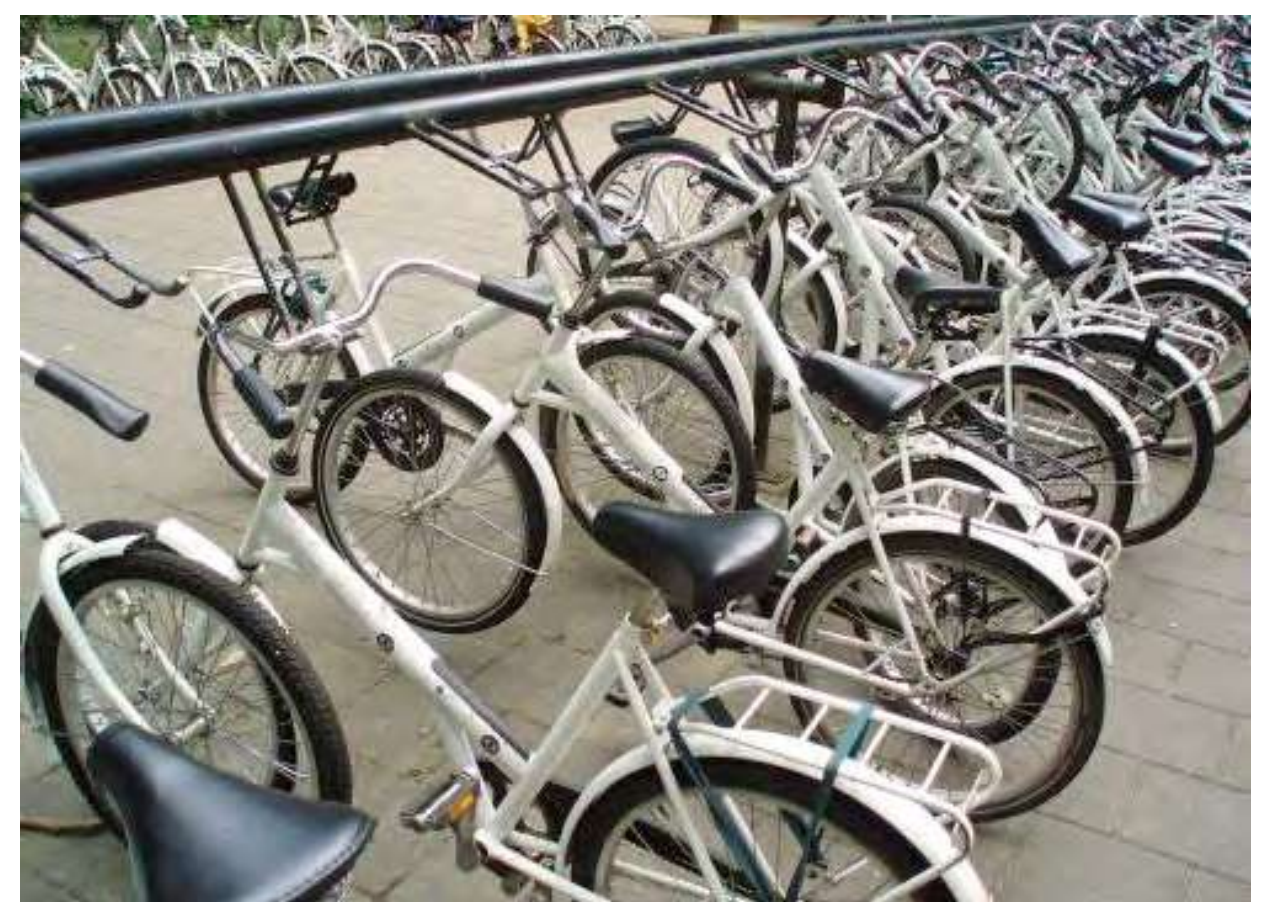

Foto 5 | Bicicletas brancas no Parque Nacional De Hoge Veluwe Fonte: Koops (2016), Historiek.

Após Provos, Schroeder (2014) revela que o primeiro sistema público de bicicletas compartilhadas começou na França, em La Rochelle, em 1976, com a iniciativa chamada Vélos Jaunes (Bicicletas Amarelas). Em 1978, foi implantado o sistema em Bremen, na Alemanha, que durou apenas três meses, pois a frota foi reduzida de 300 para 55 bicicletas devido à roubos e danos aos equipamentos (Fernández, 2011, p.30). 


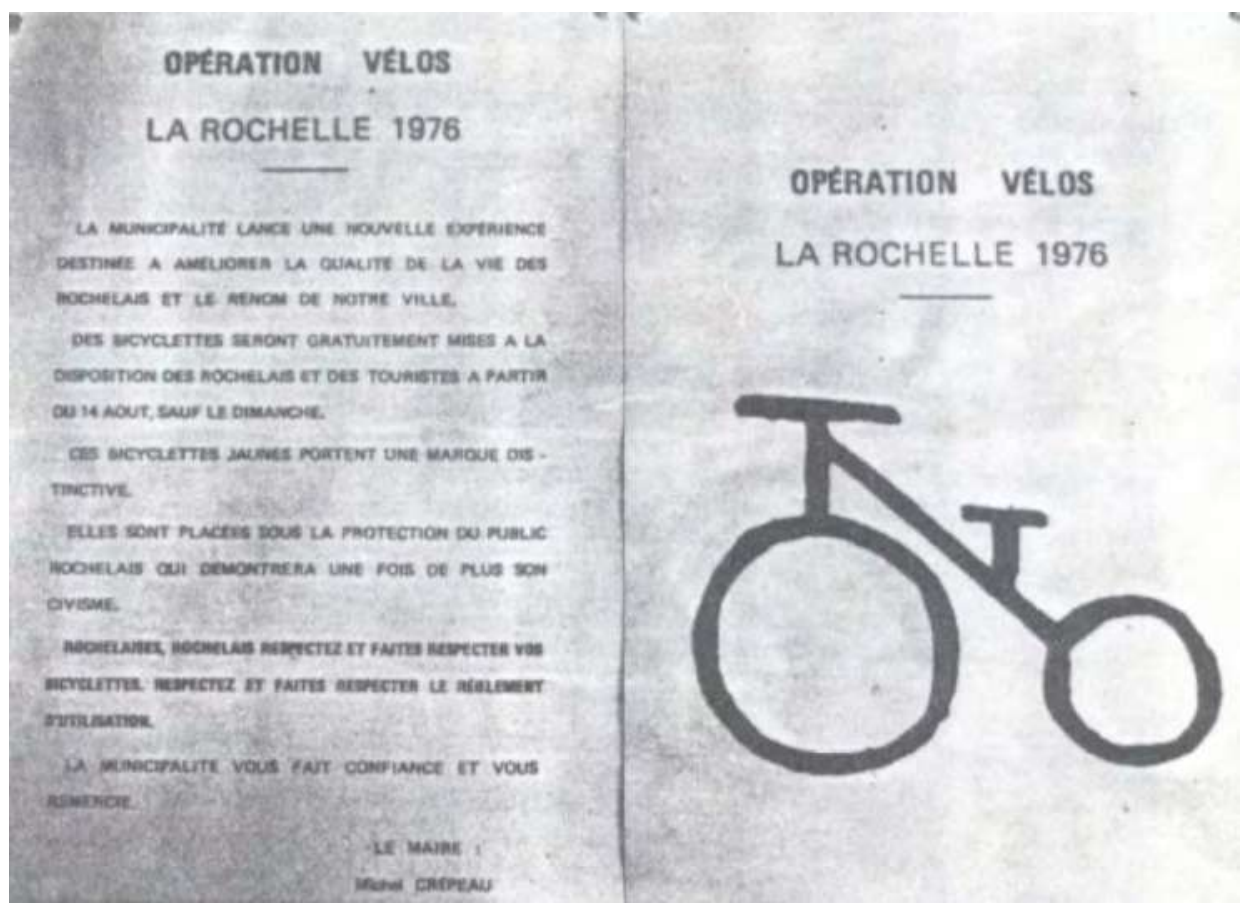

Figura 8 | La Rochelle 1976

Fonte: WEELZ.

O município está lançando uma nova experiência com o objetivo de melhorar a qualidade da baía de Rochelle e a reputaçăo de nossa cidade. Bicicletas gratuitas estarâo disponíveis para Rochelais e turistas a partir de 14 de agosto, exceto aos domingos. Estas bicicletas amarelas têm uma marca distintiva. Elas săo colocadas sob a proteçăo do público de La Rochelle, que demonstrará sua fé na maior civilidade. Rochelaises, Rochelais respeitarăo e terâo suas bicicletas respeitadas. Respeite e faça respeitar os regulamentos. O município confia em você e obrigado (traduçâo Google). 
Os sistemas da primeira geraçăo, portanto, apresentavam como principal característica a gratuidade da bicicleta, a ausência de locais fixos para retirada e devoluçăo assim como inexistência de sistema de travamento, e a pintura das bicicletas, geralmente em cor brilhante (SHAHEEN et al. 2011, p. 3). A impossibilidade de vincular a bicicleta ao usuário para puni-lo no caso de roubo ou dano contribuiu para o fracasso do sistema, e o inviabilizou economicamente.

\section{$2^{\mathrm{a}}$ geração}

DeMaio (2009) descreve que, em 1991, houve o programa de $2^{a}$ geraçâo em Farsø e Grenå e, em 1993, na Dinamarca (Nakskov), com quatro estaçôes e 26 bicicletas. 0 sistema funcionava com depósito de moedas para liberaçâo das bicicletas que se encontravam em bases fixas, distribuídas na cidade.

Em 1995, teve início o primeiro sistema de bicicletas compartilhadas em larga escala de $2^{\mathrm{a}}$ geraçấo em Copenhague, com 1.100 bicicletas, chamado Bycyklen ou City Bike, com publicidade e depósito feito com moeda; contudo, em funçăo do anonimato, as bicicletas estavam sendo roubadas (DEMAIO, 2009), e o sistema continuava vulnerável, pois năo havia controle do uso nem responsabilizaçâo dos usuários pelos danos causados às bicicletas (ITDP, 2014). 


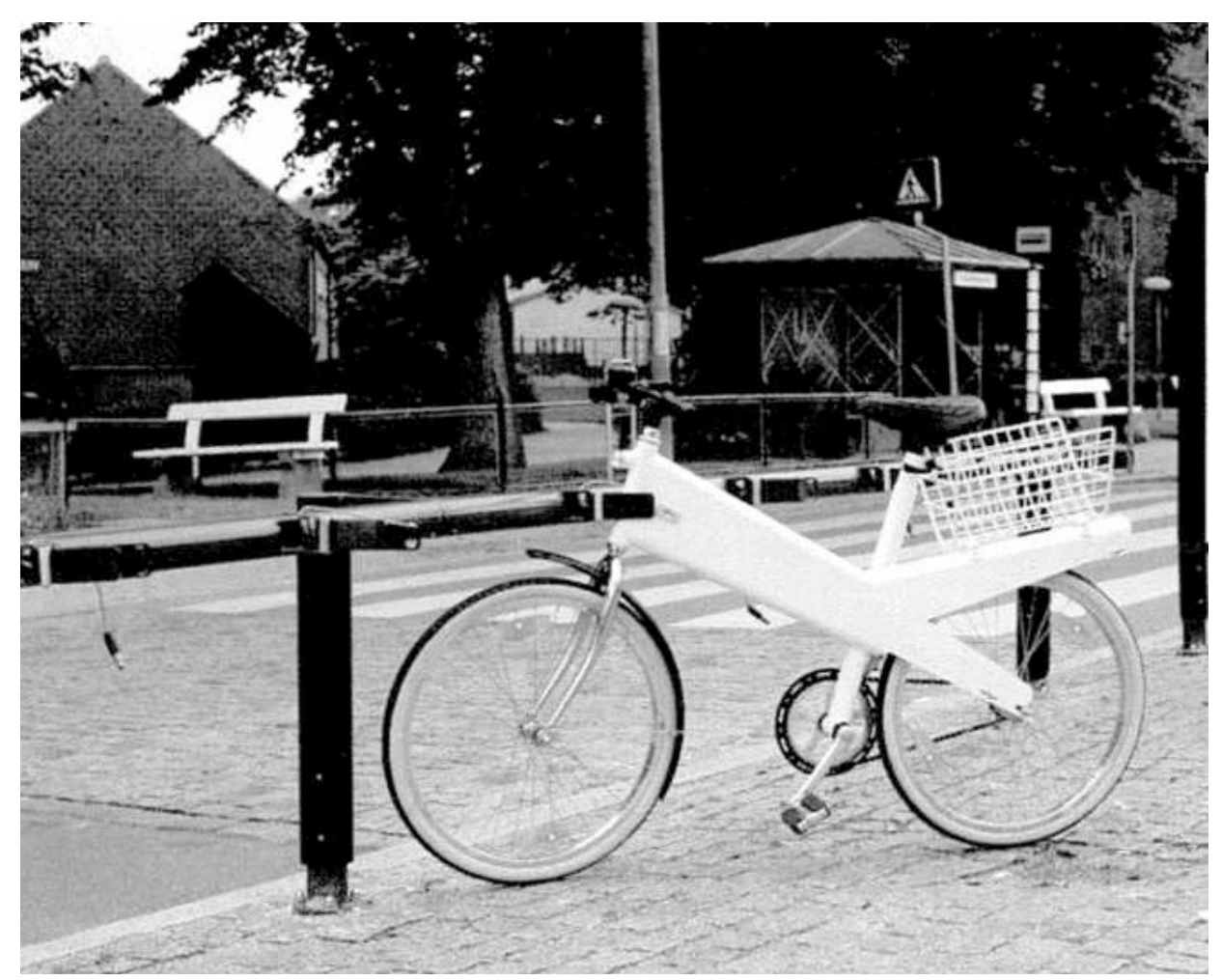

Foto 6 | Bicicletas compartilhadas (ByCyklen) em Copenhague (1995)

Fonte: Ministério dos Transportes da Dinamarca.

As bicicletas eram idênticas e desenvolvidas especificamente para o uso intenso e com locais para publicidade nas rodas, denota Schroeder (2014); entretanto, o valor da moeda para uso do sistema era muito aquém do valor da bicicleta e ocasionou casos excessivos de longa jornada e roubo. 


\section{$3^{\mathrm{a}}$ geração}

Para solucionar os problemas enfrentados pelos sistemas de $2^{\mathrm{a}}$ geraçâo, desenvolveram-se tecnologias que propiciassem identificaçăo e controle dos usuários e reduzia, assim, o impacto financeiro dos roubos e danos, ao contribuir com o salto no número de sistemas nos últimos anos.

Segundo Schroeder (2014), no sistema Bikeabout implementado na Universidade de Portsmouth na Inglaterra, em 1996, foi possível relacionar a identidade do usuário a uma bicicleta específica, condiçâo que caracteriza a $3^{a}$ geraçăo. DeMaio (2009) revela que os estudantes usavam cartăo magnético para alugar a bicicleta. Ao longo do tempo, outros avanços ocorreram como docas com travas eletrônicas, sistema de telecomunicaçăo, acesso por telefone celular, entre outros.

O ITDP (2014) descreve que em Rennes, França, houve o primeiro sistema de bicicletas compartilhadas com o uso do cartăo inteligente, em 1998, chamado Vélo à la carte, com 25 estaçōes e 200 bicicletas. De acordo com DeMaio (2009), em 2005, foi inaugurado o Velo'v de Lyon, com 1.500 bicicletas e, em 2007, o Vélib', de Paris, com 7.000 bicicletas, e tornaram-se, ambos, o modelo do sistema de $3^{a}$ geraçăo.

9 O sistema chegou ao número máximo de 23.600 bicicletas na cidade e nos subúrbios 


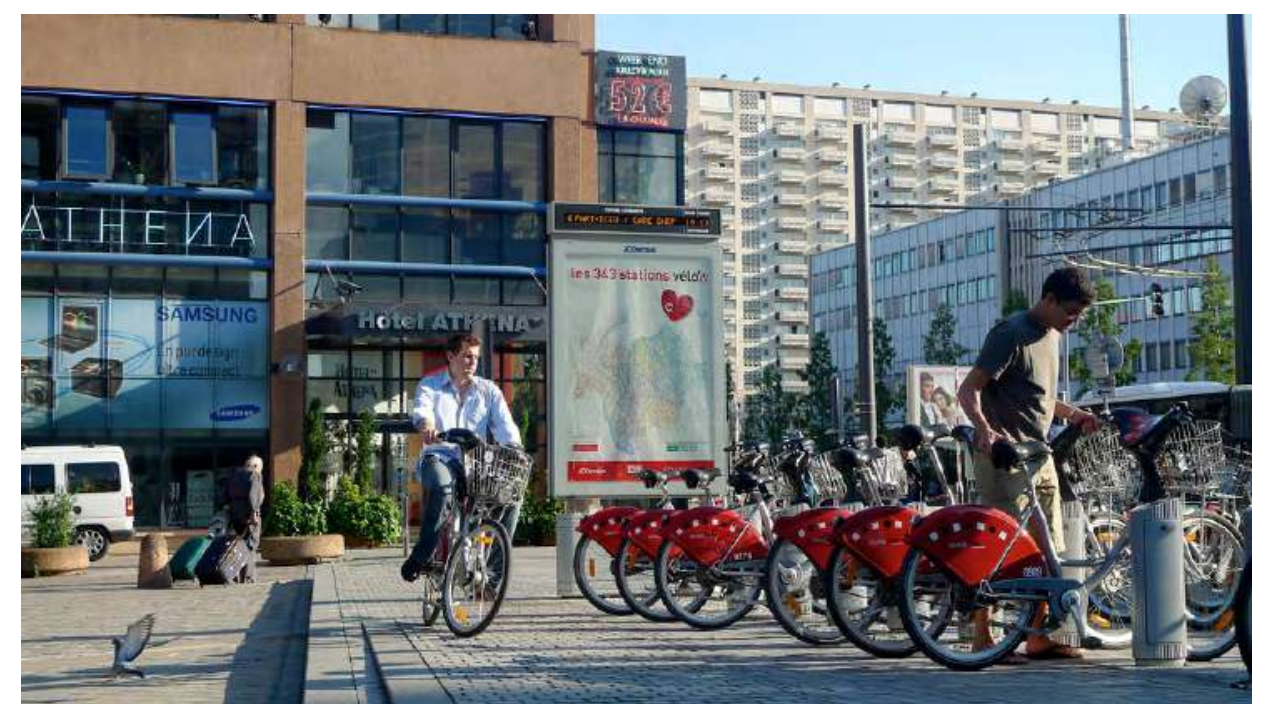

Foto 7 | Sistema Velo'v, em Lyon

Fonte: Jean-Louis Zimmermann

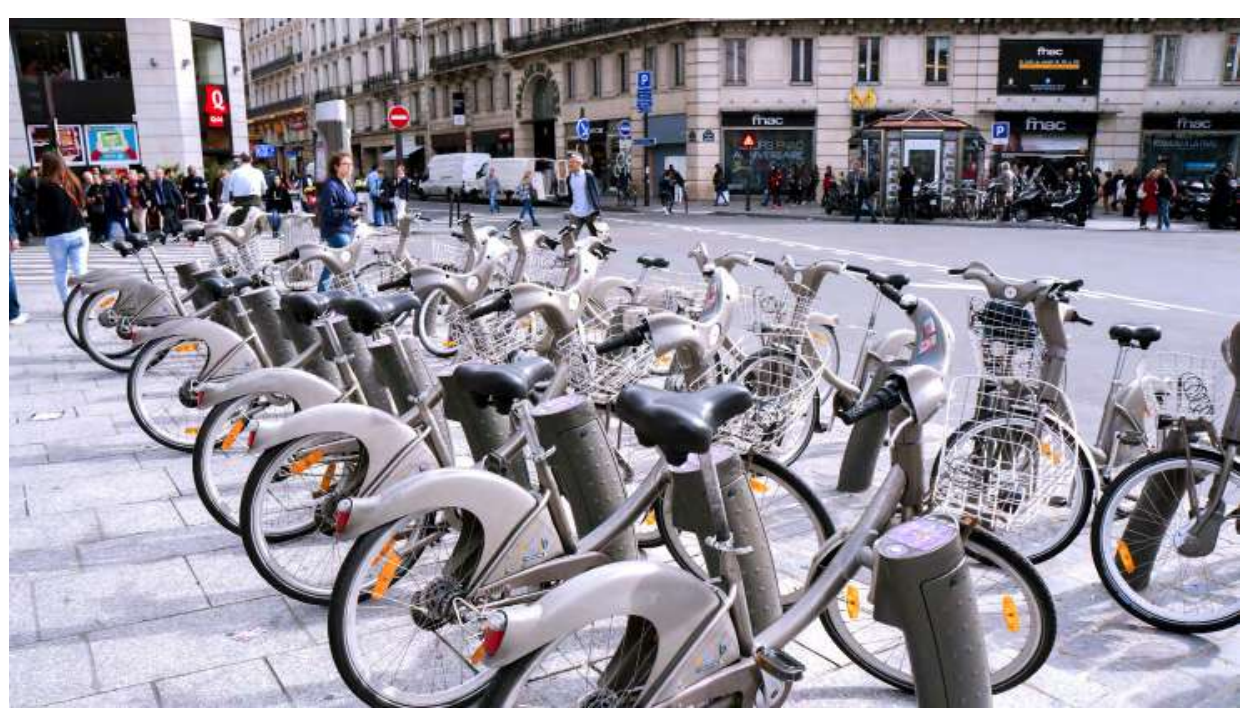

Foto 8 | Vélib, em Paris

Fonte: Frenchly.us. 
Esses sistemas possuíam assinaturas pagas que permitiam o deslocamento gratuito até uma hora, com cobrança de taxa para o uso adicional, com o intuito de incentivar a rotatividade e, portanto, o compartilhamento. Depois do sucesso do sistema, outros países lançaram seus próprios sistemas a partir de 2008, como Brasil, Chile, China, Nova Zelândia, Coréia do Sul e Estados Unidos.

O sistema chinês da cidade de Hangzhou foi inaugurado em 2008, com 4.900 bicicletas, em 2009, teve aumento para 50.000 e alcançou, em 2016, 97.000 bicicletas (ITDP, 2018e). O sistema dockless, a partir de 2014, provocou grande aumento no número de bicicletas das cidades chinesas, como Shanghai, que revela ter um milhăo de bicicletas nas ruas.

A evoluçấo da quantidade de sistemas com o desenvolvimento da tecnologia da $3^{a}$ geraçáo foi possível tanto pelo controle dos usuários quanto pelo limite do tempo das viagens, ao incentivar o compartilhamento. Além disso, o modelo financeiro com a venda de espaço de publicidade e de patrocínio proporcionou o aumento do alcance dos sistemas e garantiu a longevidade, condiçâo que a primeira e segunda geraçâo năo conseguiram atingir. No entanto, vandalismo e roubo continuam sendo fator de atençâo para viabilidade econômica dos sistemas. 


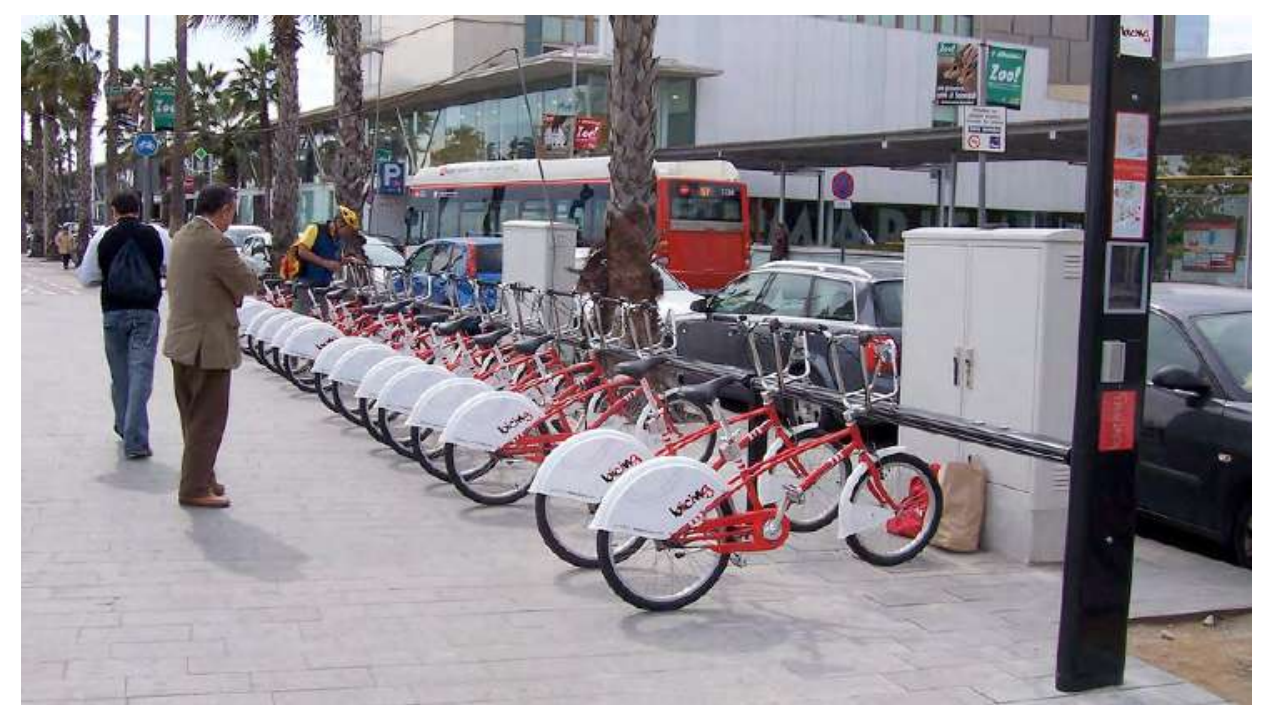

Foto 9 | Bicing, em Barcelona (2007)

Fonte: By I, Marcbel.

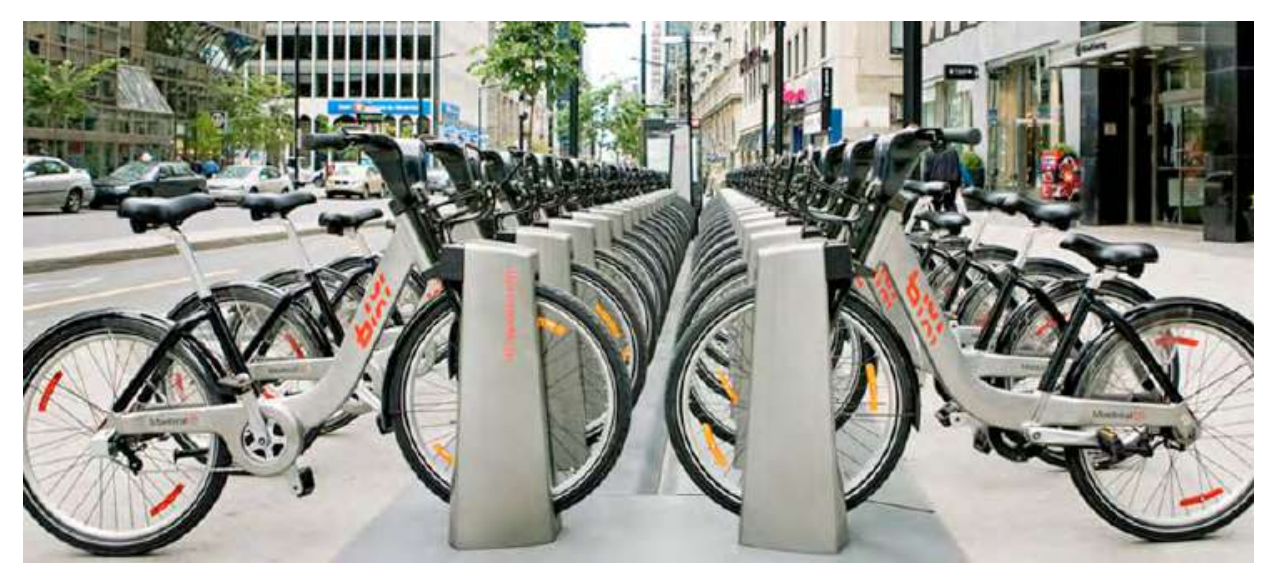

Foto 10 | Bixi, em Montreal

Fonte: Montreal Visitors Guide. 


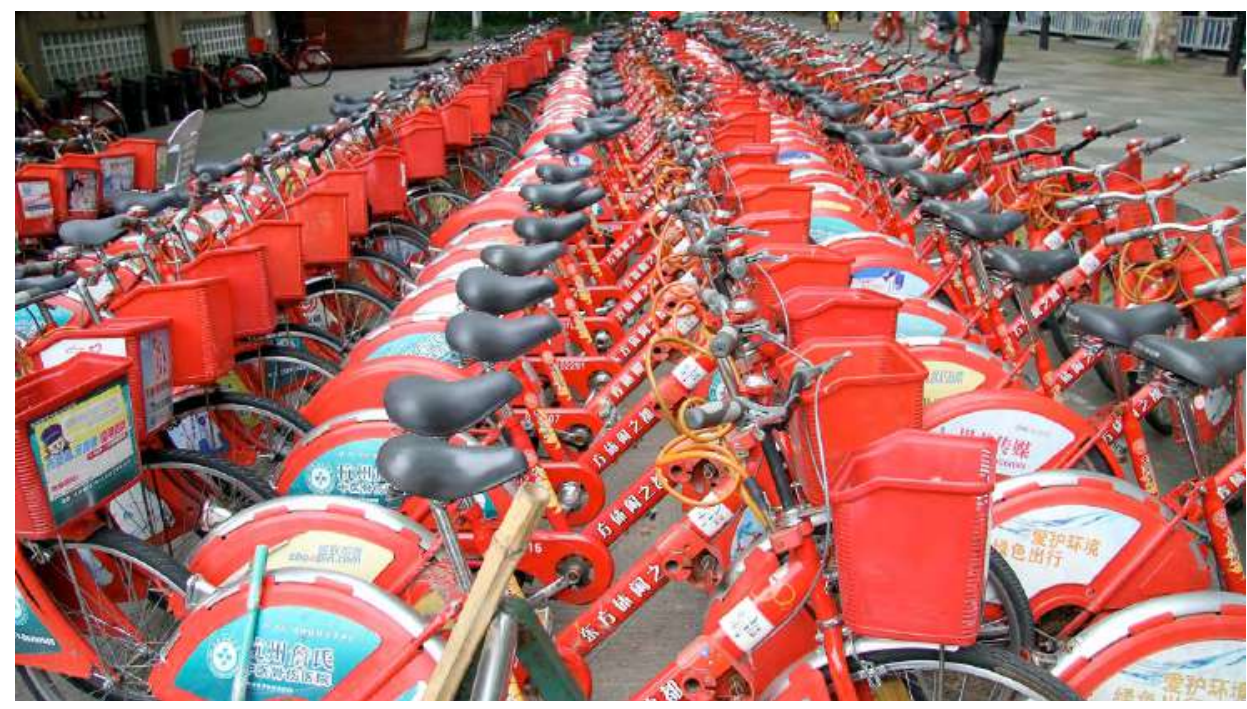

Foto 11 | Hangzhou, em China

Fonte: Clean Technica.

Antes do início do Velib', em Paris, havia apenas $30 \mathrm{~km}$ de vias seguras para o ciclista. Em 2014, a rede chegou a 700 km¹0. Silva (2014) afirma que o Velib' influenciou a rápida ampliaçấo da rede cicloviária da cidade e o aumento do número de ciclistas proporcionou melhora na segurança dos mesmos:

É este o conceito apresentado por Tilmam Bracher, do Instituto Alemáo de Urbanismo (DIFU): “...uma coisa é passar um ciclista a cada minuto. Outra, é passarem vários por minuto, assim nenhum carro se atreve a entrar na ciclofaixa". Este é o conceito de massa crítica na área do transporte cicloviário, onde um ciclista garante a segurança de outro (SILVA, 2014, p. 57).

10 Informação disponivel em: <http://www.metronews.fr/>. Acesso em: 14 jul. 2018 


\section{$4^{a}$ geração}

Há dúvida sobre a existência da $4^{\mathrm{a}}$ geraçâo de sistemas de bicicletas compartilhadas e sua diferenciaçâo quanto à geraçâo anterior. Schroeder (2014) indica que a $4^{\mathrm{a}}$ geraçâo é representada por estaçōes "móveis" sem a necessidade de escavaçăo para fixaçăo no piso, com a utilizaçăo do painel solar, modularidade que permite flexibilidade no ajuste, ao longo da operaçăo do sistema. Como exemplo, pode-se considerar o sistema Citibike, em Nova Iorque, inaugurado em 2013 como a $4^{\mathrm{a}}$ geraçấo, com 6.000 bicicletas e mais de 300 estaçôes, e chegou a 12.000 bicicletas em $2017^{11}$. Outras características seriam relacionadas às inovaçôes no processo de redistribuiçăo das bicicletas, avanços tecnológicos na operaçâo dos sistemas e integraçâo com outros modais de transporte público (Shaheen et al., 2012).

11 Informação disponivel em: <https://www.citibikenyc.com/about>. Acesso em: 19 jan. 2019. 


\subsection{Conceitos e características do SPBC}

O ITDP (2014, p. 12) define o conceito do SPBC: "permitir que qualquer pessoa retire uma bicicleta em um local e a devolva ao sistema em outro local, viabilizando assim o transporte ponto-a-ponto por traçăo humana", e revela o papel do sistema de sucesso, pela promoçâo do ciclismo como opçáo viável de transporte na cidade.

O SPBC proporciona aos cidadâos opçôes personalizadas, eficientes e saudáveis para viagens curtas, e também alivia os sistemas de transporte público existentes e podem atuar como alimentador para esses mesmos sistemas (SCHROEDER, 2014 e SHAHEEN et al., 2012).

De acordo com o Guia Global de Desenho de Ruas (NACTO, 2018), o sistema de bicicletas compartilhadas oferece nova opçăo de transporte para pessoas de diversas faixas de renda e apresenta oportunidade de promoçắo do ciclismo na cidade, quando feito bom planejamento do sistema.

Eles estendem o alcance dos sistemas de transporte coletivo existentes, tornam possíveis as viagens de trecho único (somente ida) e eliminam algumas barreiras ao ciclismo com a necessidade de aquisiçâo de uma bicicleta, acesso ao espaço para guardá-la, custos de manutençâo e preocupaçôes acerca de roubos (NACTO, 2018, p. 104).

Segundo Schroeder (2014), a bicicleta pode ser considerada a forma mais eficiente de transporte, até mais que a caminhada. De acordo com a Comissáo Europeia (2000), a bicicleta é mais competitiva que qualquer outro meio de transporte em área urbana para viagens de até cinco quilômetros, como indicado no gráfico 6 . 


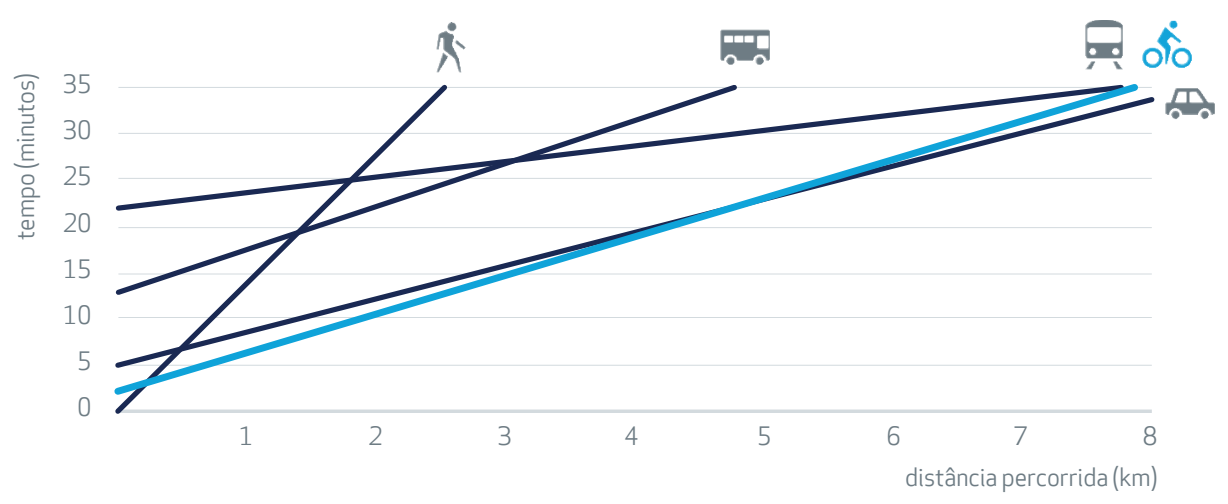

Gráfico 6 | Comparativo de velocidade de deslocamento em diferentes modais no ambiente urbano

Fonte: Comissão Europeia (2000).

O ITDP (2014) afirma que o SPBC tem o papel de reduzir o congestionamento e melhorar a qualidade do ar, por propiciar meio alternativo de transporte para viagens curtas que geralmente sâo realizadas por veículos motorizados; melhorar a acessibilidade geral e aumentar o alcance aos sistemas de transporte de massa, por preencher a lacuna entre a estaçăo de transporte público e o destino final, que pode substituir o caminhar; e aprimorar a imagem do ciclismo, por fortalecer a cultura da bicicleta na cidade.

De acordo com Schroeder (2014), muitos usuários dos sistemas de bicicletas compartilhadas têm pouca ou nenhuma experiência em ciclismo; no entanto, provou-se que isso năo pode ser considerado problema, como se pensava anteriormente: 
The presence of more cyclists on the roads usually results in safer cycling conditions. The increased number of cyclists leads to an increased awareness amongst motorists. More alert they are to cyclists' presence and the necessity of sharing the space. (SCHROEDER, 2014, p. 171). ${ }^{12}$

Segundo Silva (2014), o sistema de bicicletas compartilhadas Velib', o primeiro de $3^{a}$ geraçăo em larga escala, obteve sucesso, pois possibilitou que a bicicleta tivesse papel de transporte de uso público, năo mais individual, a partir também da integraçấo com outros sistemas de transporte. Em conversa com Eric Britton ${ }^{13}$, Silva (2014) revela que o principal conceito para o êxito do sistema de bicicletas compartilhadas é a elevada densidade das estaçōes, com distâncias entre si de 300 metros, ao permitir o deslocamento porta a porta, pois o ciclista irá caminhar no máximo 150 metros até seu destino. Segundo ele, outro fator importante é a localizaçăo das estaçôes próximas ao transporte coletivo, em área de grande densidade de emprego, ao garantir a integraçăo modal e o uso do sistema por aqueles que trabalham na área de cobertura, e nâo apenas residem.

Sadik-khan e Solomonow (2016) descrevem a contribuiçăo do sistema de bicicletas compartilhadas em Nova Iorque como complemento às viagens em transporte público, ao substituir o caminho a pé de estaçōes de metrô e ônibus até o destino final.

12 A presença de mais ciclistas nas ruas geralmente resulta em condições de ciclismo mais seguras. 0 aumento do número de ciclistas leva a maior conscientização entre os motoristas. Mais alertas eles se encontram para a presença dos ciclistas e a necessidade de compartilhar o espaço (tradução nossa).

13 Eric Britton participou da equipe de desenvolvimento do Velib' e é fundador do site worldstreets.com. 
About half the trips in New York City are less than three miles, and its relatively flat topography makes it easy for most people to bike a mile or two in ten minutes without breaking a sweat. While New York is a transit-dense city, not all development is concentrated along subway lines, leaving huge swaths, and hundreds of thousands of New Yorkers, just beyond walking distance of subways stations or bus transit. Bike Share could be used for short trips, extending the reach of New York's existing transit options. It could make the ten-minute walk from the subway a pleasant three-minute cruise on sturdy bikes with Alwaysrunning lights. (SADIK-KHAN; SOLOMONOW, 2016, p. 185). ${ }^{14}$

A maioria dos usuários do SPBC sâo aqueles que percebem o compartilhamento de bicicleta como modo mais conveniente do que os demais meios de transporte, comenta Schroeder (2014), ao adotá-lo em alguns trechos dos trajetos diários e nâo necessariamente as pessoas que incorporam as bicicletas nos percursos diários, pois essas geralmente migram para as bicicletas próprias.

14 Aproximadamente metade das viagens em Nova lorque possui menos de 4,8 Km de distância, e a topografia é relativamente plana o que torna fácil para a maioria das pessoas pedalar 1,5 ou três quilômetros em dez minutos sem suar. Enquanto Nova lorque é uma cidade densa, nem todos os empreendimentos estão concentrados ao longo de linhas de metrô, deixando grandes áreas desatendidas, e milhares de nova iorquinos a distâncias não caminháveis das estações de metrô ou de pontos de ônibus. As bicicletas compartilhadas poderiam ser usadas para viagens curtas, estendendo o alcance das opções de transporte existentes. Poderia transformar a caminhada de dez minutos desde o metrô em percursos agradáveis de três minutos em bicicleta com semáforos sempre abertos (tradução nossa). 
Schroeder (2014) lista os benefícios no uso do SPBC.

_vantagens de saúde, para o ciclista e meio ambiente;

_incentiva o investimento em outras infraestruturas e políticas

para a bicicleta, ao aumentar a segurança do ciclista;

_o SPBC promove a necessidade "abrupta" do uso da infraestrutura

cicloviária, em lugar da necessidade gradual;

_os motoristas desenvolvem maior atençăo e reconhecimento dos ciclistas, o que aprimora a segurança no uso da bicicleta no dia a dia, ao apresentar papel fundamental em tornar a bicicleta escolha confiável de meio de transporte nas cidades;

_o compartilhamento de bicicletas promove o DOT, pelo uso da bicicleta e a revitalizaçăo urbana;

_a estaçấo de bicicletas compartilhadas gera um "hub", espaço de transiçấo que ajuda a catalisar a renovaçăo, ao atrair usuários para o local, que por sua vez atrai lojas, restaurantes, e aumenta o valor dos lotes vizinhos, ao promover a qualidade do espaço urbano na área. Esse ponto específico atualmente é visto pelos comerciantes de maneira antagônica. Eles acreditam que a estaçâo traz consequências negativas para seus negócios, principalmente por ocupar o espaço do carro estacionado, considerado principal meio de transporte dos seus clientes; _ o SPBC é associado com a imagem de cidade verde, sustentável, ativa e com alta qualidade de vida. 
Segundo DeMaio (2009), muitos sistemas de bicicletas compartilhadas ocasionaram nas cidades o aumento do número de ciclistas, a diminuiçấo da emissăo dos gases de efeito estufa e o aprimoramento da saúde pública. 0 ITDP (2014, p. 17) também revela a capacidade que o SPBC possui de atrair novos ciclistas. $O$ exemplo apresentado é o do sistema Velo'v em Lyon, que propiciou o aumento de $44 \%$ do uso da bicicleta na cidade.

O aumento na porcentagem do uso da bicicleta nos deslocamentos diários se deve às novas viagens geradas pelas bicicletas compartilhadas, ao aprimoramento da intermodalidade, ao resolver o problema da primeira e última milha e à diminuiçâo das viagens por veículos individuais motorizados. Segundo DeMaio (2009), algumas viagens geradas pelo sistema de bicicletas compartilhadas substituem outros modos de transporte; entretanto, năo ocasiona a diminuiçâo no uso do transporte público por aumentar o alcance dos usuários nas duas pontas da viagem.

Segundo Frade e Ribeiro (2013), o SPBC provoca além de impactos positivos no meio ambiente, a melhoria na qualidade da vida urbana e melhor experiência no uso do espaço urbano, modificaçôes nos padróes de mobilidade, pela substituiçấo do uso de outros modais para as bicicletas compartilhadas.

No entanto, alguns estudos revelam que muitos usuários do SPBC nâo substituem, na maioria, o automóvel, que ainda possui comodidade no deslocamento porta-a-porta, e sim o transporte público, como indicado na tabela 2. Por exemplo, 65\% das viagens realizadas no Velib' foram substituídas pelos antigos usuários de ônibus ou metrô, enquanto apenas $8 \%$ era antes realizadas por automóveis ou motos. 


\begin{tabular}{|c|c|c|c|c|}
\hline $\begin{array}{c}\text { meio de } \\
\text { transporte }\end{array}$ & Bicing | Barcelona & BIXI| Montreal & Vélib | Paris & Velo'v | Lyon \\
\hline ônibus ou metrô & $51 \%$ & $33 \%$ & $65 \%$ & $50 \%$ \\
\hline $\begin{array}{c}\text { automóvel ou } \\
\text { motocicleta }\end{array}$ & $10 \%$ & $2 \%$ & $8 \%$ & $7 \%$ \\
\hline táxi & - & $8 \%$ & $5 \%$ & - \\
\hline caminhada & $26 \%$ & $25 \%$ & $20 \%$ & $37 \%$ \\
\hline bicicleta & $6 \%$ & $28 \%$ & - & $4 \%$ \\
\hline outros & - & $4 \%$ & - & $2 \%$ \\
\hline
\end{tabular}

Tabela 2 | Porcentual de viagens de cada modal substituído pelo SPCB em Barcelona,

Montreal, Paris e Lyon

Fonte: Midgley (2011, p. 16). Elaboração e tradução nossa.

\subsection{Planejamento de SPBC com estação}

O contexto local deve ser levado em consideraçáo no planejamento do sistema de bicicletas compartilhadas, segundo o ITDP (2014), e fatores como densidade, topografia, clima, infraestrutura e cultura influenciam na adaptaçăo do projeto em cada cidade. Algumas características em comum de sistemas bem-sucedidos săo listadas a seguir (ITDP, 2014, p. 14):

_a densa rede de estaçóes distribuídas por toda a área de cobertura, com espaçamento médio de 300 metros entre as estaçôes; _bicicletas confortáveis, próprias para o transporte casa-trabalho, com peças e tamanhos especialmente concebidos para desencorajar o roubo e a revenda;

_sistema de travamento totalmente automático que permite aos usuários retirarem e devolverem suas bicicletas nas estaçōes; _sistema de rastreamento sem fio - por exemplo, por meio de dispositivos de identificaçâo de radiofrequência (RFID) - que 
localiza onde a bicicleta foi retirada e devolvida, além de identificar o usuário; _acompanhamento em tempo real da ocupaçăo das estaçóes por serviços móveis, como por exemplo, o serviço de rádio de pacote geral (GPRS);

_informaçôes em tempo real para os usuários por diversos canais, como internet, celulares e/ou terminais locais;

_estruturas de preço que incentivam viagens curtas e ajudam a maximizar o número de viagens de bicicleta por dia.

A implantaçăo de programas de bicicletas compartilhadas tem muitas vezes relaçâo com metas públicas de "aumento do uso urbano da bicicleta, reduçâo do congestionamento, melhoria da qualidade do ar e aumentar a oferta de opçōes de Transporte Năo Motorizado (TNM)" (ITDP, 2014, p. 16). Sua grande vantagem, quando comparado a outros sistemas de transporte, consiste no baixo custo e menor prazo de implementaçâo.

Segundo o guia do ITDP (2018), a localizaçâo ideal das estaçôes de bicicletas compartilhadas deve seguir as seguintes diretrizes:

_locais ensolarados, longe da cobertura das árvores se possível, para garantir a eficiência da captaçăo da energia solar; _proximidade a intersecçōes, para maior visibilidade das bicicletas; _proximidade a estaçôes de transporte público, para propiciar a integraçâo modal; _área de alta visibilidade e iluminaçâo pública, pela inibir o vandalismo; 
_fácil acesso ao usuário e aos veículos de manutençăo e rebalanceamento;

_proximidade à infraestrutura cicloviária, para a maior segurança do ciclista;

_năo bloquear caixa de inspeçăo do piso;

_quando em leito carroçável, preferência por vias de baixa velocidade e baixo volume de carros;

_quando em praças e calçadas, garantir no mínimo dois metros de passagem para os pedestres.

Os objetivos principais que o sistema de bicicletas compartilhadas deve buscar, ainda segundo o guia do $\operatorname{ITDP}(2018)$ :

densidade | atingir a densidade ideal uniforme na área de cobertura do sistema. A redundância é importante para garantir a boa experiência do usuário, pois caso a estaçâo esteja cheia ou vazia, sempre haverá outras estaçôes próximas para atendê-lo, além de garantir sempre uma bicicleta a distância caminhável de onde ele estiver;

_intermodalidade / o sistema de bicicletas compartilhadas é complementar ao sistema de transporte público; portanto, é essencial que as estaçōes sejam posicionadas próximas aos acessos das estaçóes de trem e metrô e aos pontos dos corredores de ônibus, e propiciar a conexāo fácil aos usuários e contribuir para a soluçăo do problema de transporte da última milha (último quilômetro e meio);

_infraestrutura cicloviária | sempre que possível, as estaçôes devem estar localizadas próximas às ciclovias e às ciclofaixas, 
e contribuir para consolidar essa infraestrutura. Pode ser utilizada inclusive como barreira entre a ciclovia e as vias dos carros, ao oferecer segurança aos ciclistas;

disponibilidade em áreas de uso misto | a localizaçâo ideal das estaçôes seria em zonas de uso misto, ao gerar viagens durante o dia e a noite, náo apenas nos horáros de pico.

No gráfico 7, denota-se a relaçăo da densidade com o uso do sistema, identificado como viagens por dia por bicicleta (VDB).

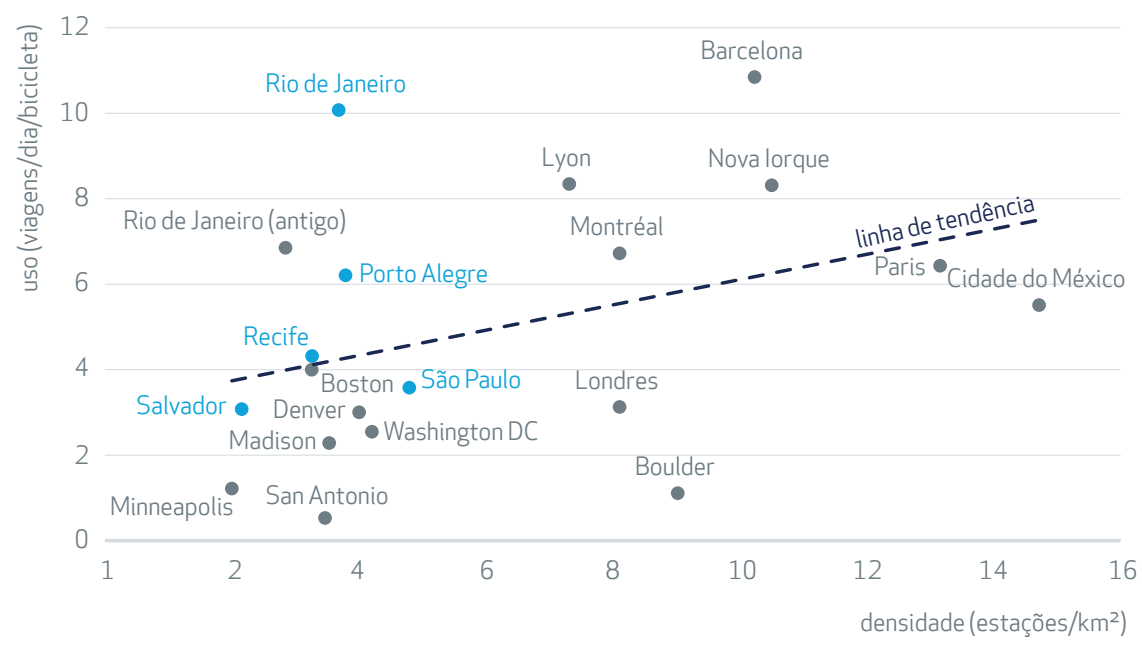

Gráfico 7 | Uso dos sistemas de compartilhamento de bicicletas: número de viagens/dia/ bicicleta (VDB) e a densidade de estações

ITDP (2014, p. 47). Pontos em azul: dados tembici referentes aos três últimos meses de 2018. Elaboração própria.

Sadik-Khan e Solomonow (2016) reforçam a importância da densidade para o sistema de bicicletas compartilhadas no trecho a seguir. Descrevem que as estaçôes devem ser distribuídas de maneira densa, ao configurar rede urbana: 
Density is destiny for bike share. Stations must be densely distributed in an urban network or the entire system will fall apart. Bike-share riders must have a variety of stations options where they can pick up and drop off bikes. Station density provides redundancy, reliability, and peace of mind to riders that they won't be left stranded with a bike but no dock or station to return it, or with no alternative stations if a station is out of bikes (SADIK-KHAN; SOLOMONOW, 2016, p. 203) ${ }^{15}$.

Segundo o Guia Global de Desenho de Ruas (NACTO, 2018), a área de cobertura inicial do sistema deve ser definida de maneira criteriosa, ao promover expansōes estratégicas faseadas, e deve cobrir áreas contíguas ao incluir centros de empregos, polos culturais e de lazer, e zonas de alta densidade, para que ofereça opçăo de transporte significativa. Denota também a importância da densidade e do espaçamento reduzido entre as estaçōes do sistema, pois relaciona o uso do sistema pela conveniência do usuário, que náo caminha confortavelmente mais de 300 metros para encontrar uma estaçâo de bicicletas compartilhadas. Como o Guia defende a manutençâo da mesma densidade por toda a regiâo de implantaçâo do sistema, o tamanho das estaçôes deve ser diferente, e nâo o espaçamento, de acordo com as características de cada bairro.

15 Densidade é o destino para o compartilhamento de bicicletas. As estações devem ser densamente distribuídas na rede urbana ou todo o sistema irá fracassar. Os usuários de bicicletas compartilhadas devem ter variedade de opções de estações, onde possam retirar e devolver as bicicletas. A densidade de estações fornece a redundância, confiabilidade e tranquilidade aos usuários que não ficarão presos com uma bicicleta sem estação para devolvê-la, ou sem estações alternativas se uma estação estiver sem bicicletas (tradução nossa). 
Quando uma estaçâo estiver lotada ou vazia, o usuário deve ser capaz de se dirigir com facilidade até a estaçăo mais próxima para devolver ou retirar uma bicicleta. As cidades devem garantir que a distância entre as estaçôes nâo ultrapasse os 300 m em toda a área do programa. Isso se traduz em uma densidade global de 11 estaçóes por quilômetro quadrado (NACTO, 2018, p. 104).

Os passos descritos a seguir fazem parte do processo de planejamento da localizaçaáo das estaçóes de bicicletas compartilhadas, após definiçăo da área de cobertura e número de estaçôes do sistema (esta última condiçâo depende do estudo de viabilidade financeira).

_Distribuição homogênea das estações na área de cobertura feita remotamente, a partir do espaçamento de 300 a 500 metros entre estações.

No ambiente profissional, gerenciei o planejamento dos sistemas de bicicletas compartilhadas de diversas cidades brasileiras e da América Latina e essa metodologia era adotada. Previamente às visitas a campo, a cidade era estudada de maneira remota e virtual, com a ferramenta do Street View, na qual já se pré-selecionava possíveis locais para o posicionamento das estaçôes de bicicletas compartilhadas para auxiliar e agilizar a etapa in loco. A área de cobertura, por sua vez, é determinada ao serem considerados todos os aspectos elencados, em estudos realizados para cada cidade. 
_Processo participativo com a população do bairro, para garantir suporte e equidade nas definições.

O Departamento de Transporte de Nova Iorque, por exemplo, conduziu diversas reuniôes com os representantes das comunidades. Alguns sistemas adotam a ferramenta virtual online para promover a participaçâo da populaçăo na indicaçăo dos locais das estaçôes em mapa colaborativo compartilhado.

Infelizmente, essa etapa do processo participativo năo costuma ser adotada nas cidades brasileiras, devido à falta de interesse e de engajamento por parte do poder público, que năo se envolve, nem faz a mediaçâo entre a empresa privada operadora e planejadora do sistema e a sociedade civil. Buscou-se, sempre que possível, o diálogo e planejamento em conjunto com os responsáveis pelas entidades de ciclistas das cidades, bem como o poder público envolvido, mas náo foram realizadas audiências públicas com os moradores ou trabalhadores dos bairros que receberam as estaçôes de bicicletas compartilhadas.

_Definição final da localização das estações por intermédio de visitas em campo.

Essa etapa é muito importante, pois diversos aspectos devem ser analisados para comprovar a viabilidade e melhor posicionamento das estaçōes. É recomendável que a visita seja conduzida de bicicleta, e propicie aos planejadores o conhecimento da regiăo pela perspectiva do ciclista e, portanto, do usuário do sistema. Com câmera fotográfica para documentaçăo e fita métrica para realizar as mediçôes do local para posterior realizaçâo do projeto executivo, no lugar é feita a análise se a área disponível é suficiente para o tamanho da estaçăo ideal. 
Cada cidade opta por um processo de análise e envolvimento na definiçăo da localizaçăo das estaçôes. Algumas requerem a visita em conjunto de todos os pontos a serem definidos; no entanto, pela falta do costume do pedalar na cidade, a visita é feita de carro e atrapalha a percepçăo de proximidade entre as estaçóes. Outras cidades, apenas solicitam o projeto executivo, e a visita é feita internamente (pelas pessoas da empresa operadora), de bicicleta ou a pé, e os técnicos do poder público podem visitar ou nâo os locais sugeridos, sendo necessária a visita em conjunto apenas nas estaçôes que năo tiveram consenso.

Para a localizaçâo da estaçăo, as seguintes opçôes devem ser consideradas (ITDP, 2018e):

_os espaços ocupados por vagas de automóveis nos leitos carroçáveis sâo locais ideais para as estaçôes de bicicletas compartilhadas. Barcelona converteu aproximadamente 1.200 vagas para o uso do sistema público Bicing. Esse ponto é bem controverso também nas cidades brasileiras, pois o automóvel ainda é considerado prioridade na ocupaçâo do espaço público, e tanto áreas comerciais quanto residenciais (ou mistas) reclamam da perda de vagas de estacionamento; _espaços geralmente nâo utilizados pelos pedestres, como a área da calçada entre canteiros de árvores ou demais elementos do mobiliário urbano, desde que náo impeça a circulaçāo dos mesmos;

_espaços ignorados e náo utilizados, como embaixo de pontes e passarelas, desde que com as devidas intervençóes para garantir a segurança. 
É importante analisar também a acessibilidade das estaçồes, pois os usuários devem chegar até ela a pé, com segurança; a incidência do sol no painel solar para carregamento eficiente das baterias de funcionamento do sistema; e a existência de interferências no piso, como buracos e caixas de inspeçăo, para năo bloquear o acesso.

\subsection{Outros modelos de compartilhamento}

\subsubsection{Sistema dockless}

O sistema de bicicletas compartilhadas dockless, com início na China em 2014 (ITDP, 2018b), nâo possui docas fixas (estaçôes) distribuídas na cidade para seu compartilhamento. As bicicletas possuem travas próprias, assim como pequenos paineis solares para garantir a energia para seu funcionamento, e Sistema de Posicionamento Global (GPS) para sua geolocalizaçăo no contexto urbano, ao permitir ao usuário deixar a bicicleta no destino, sem necessitar buscar algum ponto físico especifíco para devoluçăo, como no SPBC com estaçăo.

Essa é a grande vantagem do sistema dockless, ao aproximar-se do funcionamento do transporte individual, por permitir o deslocamento porta-a-porta. Entretanto, se năo há muitas bicicletas em toda a área de cobertura, a confiabilidade do sistema pode ser comprometida, pois o usuário năo possui garantia de que poderá utilizá-la quando necessário e prejudica a adoçăo do meio de transporte no cotidiano. Por esse motivo, como veremos a seguir, o 
número de bicicletas dos sistemas é muito elevado e causa até transtornos em funçáo do excesso de oferta.

O modelo depende primordialmente da tecnologia do smartphone e de internet de alta velocidade, e os operadores costumam cobrar taxas baixas pelo uso por viagem ${ }^{16}$. Para utilizar o sistema, basta baixar o aplicativo da empresa, verificar a localizaçăo da bicicleta mais próxima que possa ser destravada, escanear o código QR com o celular ou inserir o PIN no teclado ou cadeado da bicicleta.
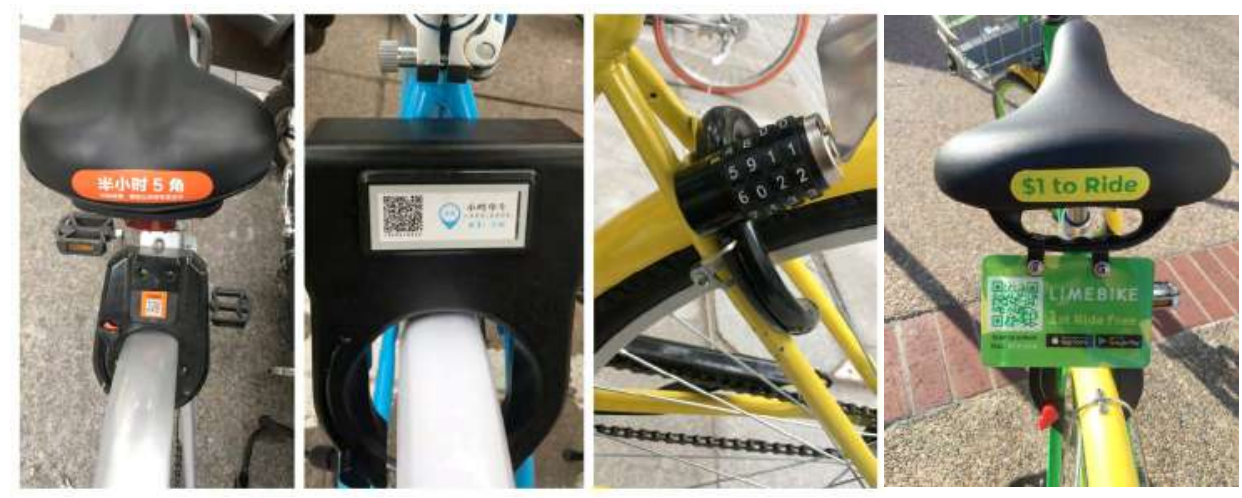

Foto 12 | Diferente modelos de travas de bicicleta dockless

Fonte: ITDP (2018a). Fotos 1,3 de Emma Lee, 2 de Richard Darsono, 4 de David Alpert.

Suportado em sua grande maioria por fundos de capital de risco, as empresas de bicicletas dockless funcionam sem o subsídio do governo e

16 O modelo com estação além da opção de pagamento por viagem também costuma trabalhar com a venda de planos (assinaturas) por determinados períodos (exemplo: um dia, três dias, mensal e anual). Caso o usuário ultrapasse o período da gratuidade estabelecido que varia de trinta a sessenta minutos, a depender do sistema, há cobrança de multa pelo tempo excedido. 
permitem evitar o longo processo burocrático que costuma existir para o modelo com estaçăo de um só operador (ITDP, 2018a).

A implementaçâo do sistema dockless pode ser mais simples e rápida, quando năo passa pela burocracia de autorizaçăo de uso do espaço urbano. As empresas de bicicletas e patinetes elétricos, no caso do Brasil, colocam-se como serviço individual privado, com baixa barreira de entrada nas cidades, ao equiparar-se aos aplicativos de carona (como Uber e Cabify). No entanto, a utilizaçăo privada com fim econômico de um bem público năo condiz com a Lei Orgânica que regula a cessấo do espaço público e que indica se o instrumento legal deve ser feito a partir de termo de permissáo ou concessâo, com concorrência.

Dessa forma, algumas cidades já começaram a regulamentar o serviço, inclusive com a obrigatoriedade de utilizar espaços físicos como estaçōes virtuais, para organizaçáo do espaço público, com intuito de evitar conflito com os pedestres, de acordo com o Estatuto do Pedestre.

Em outubro de 2017, havia mais de setenta empresas de bicicleta dockless na China, ao operar aproximadamente dezesseis milhôes de bicicletas, sendo 5.1 milhōes concentradas em três cidades: Beijing (2.4 milhôes), Shanghai (1.5 milhăo) e Chengdu (1.2 milhăo), todas as quais também possuem SPBC com estaçâo. Geralmente, essa quantidade de bicicletas foi disponibilizada nas ruas das cidades em questōes de poucos meses, e ocasionou problemas de superlotaçâo no espaço público.

As duas maiores empresas de bicicletas dockless, Ofo e Mobike, operam aproximadamente catorze milhôes de bicicletas em mais de 165 cidades 
chinesas, gerando sessenta milhôes de viagens por dia na média (ITDP, 2018a).

O ITDP (2018c) revela o grande potencial do sistema dockless na diminuiçăo do uso do carro nas cidades. Em Shenzhen (China), estima-se que 10\% das viagens realizadas com automóveis foram substituídas pelas bicicletas dockless.

Segundo ITDP China (2017), em Beijing e Shanghai, o número de viagens de menos de cinco quilômetros realizadas por automóveis decresceu pela primeira vez na história, após o início da operaçâo dos sistemas dockless da Mobike e Ofo, como pode ser identificado no gráfico 8.

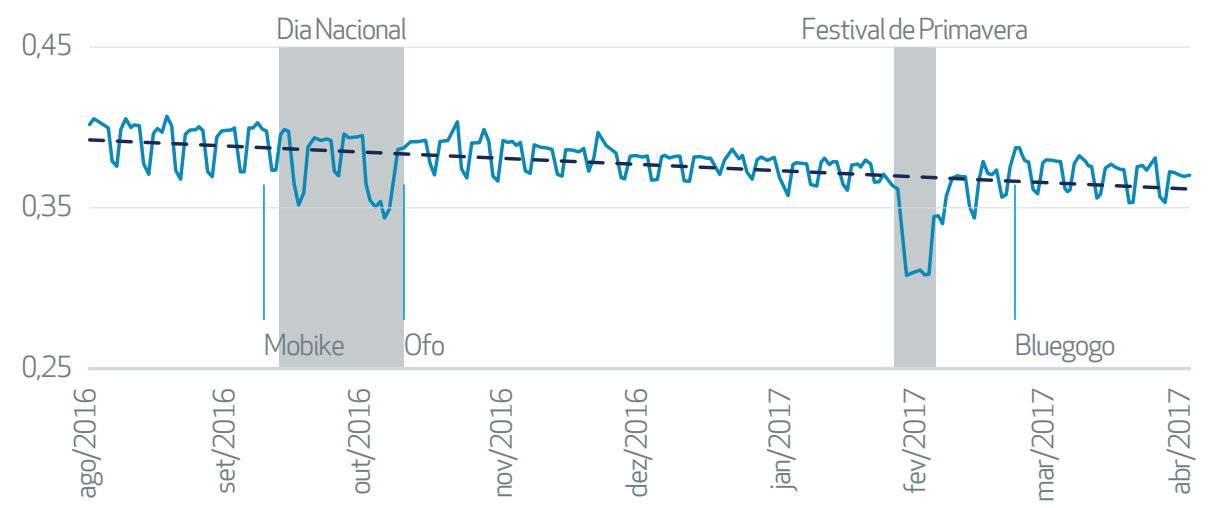

Gráfico 8 | Início da operação de Sistemas Dockless e viagens realizadas por automóveis em distâncias menores de cinco quilômetros em Beijing e em Shanghai

Fonte: ITDP (2018d, p. 2). Relatório de Análise de Tráfego nas Grandes Cidades (tradução nossa). 
Para a operaçăo do sistema, a manutençâo é complexa, pois as bicicletas podem estar em qualquer lugar da cidade, sem a previsibilidade dos locais fixos. Além disso, as bicicletas săo mais baratas, ao optar-se pelo descarte e substituiçâo rápidos em vez de equipamentos mais duráveis. Segundo artigo de Fortunati (2018), o ITDP da China informou que isso ocorre nas cidades chinesas, pois o poder público confisca as bicicletas que estăo em locais inadequados (como nas calçadas, quando atrapalham o pedestre) e as empresas fabricam novas bicicletas, em lugar de gastar tempo e dinheiro na tentativa de recuperá-las.

Com o excesso da oferta de bicicletas de diversas empresas diferentes, as cidades chinesas começaram a vivenciar problemas, como calçadas bloqueadas e vandalismo, e deram origem a cemitérios de bicicletas e preocupaçóes sobre o controle de qualidade, manutençăo e gerenciamento dos sistemas. De acordo com European Cyclists' Federation (ECF), esses problemas cresceram exponencialmente em funçâo da falta inicial de regulamentaçôes e do fluxo maciço de fundos de capital de risco, a permitir número elevado de bicicletas que năo recebiam manutençăo, nem processo de logística de redistribuiçăo por parte das empresas, essas com baixo quadro de funcionários, quando comparado ao número total de bicicletas (ITDP, 2018a). 

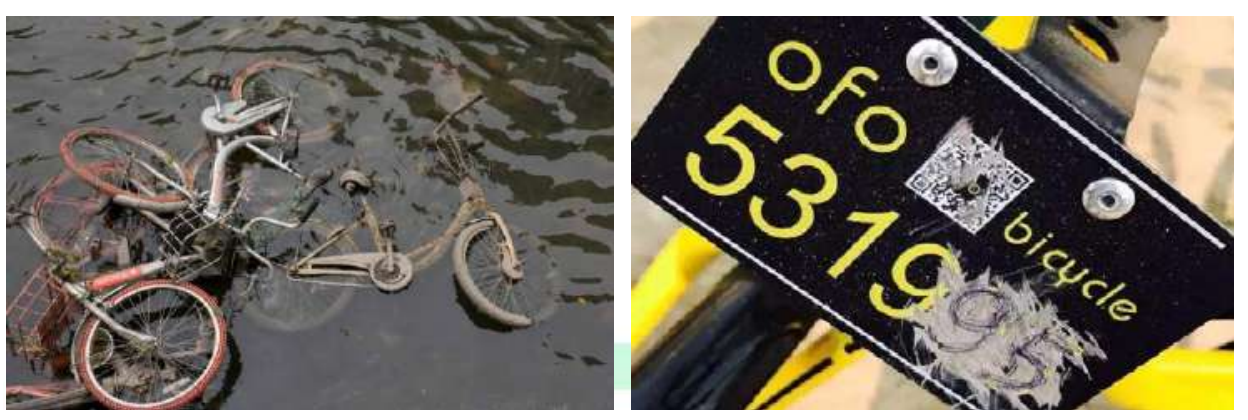

Foto 13 | Exemplos de vandalismo de bicicletas do sistema dockless na China Fonte: ITDP China (2017)

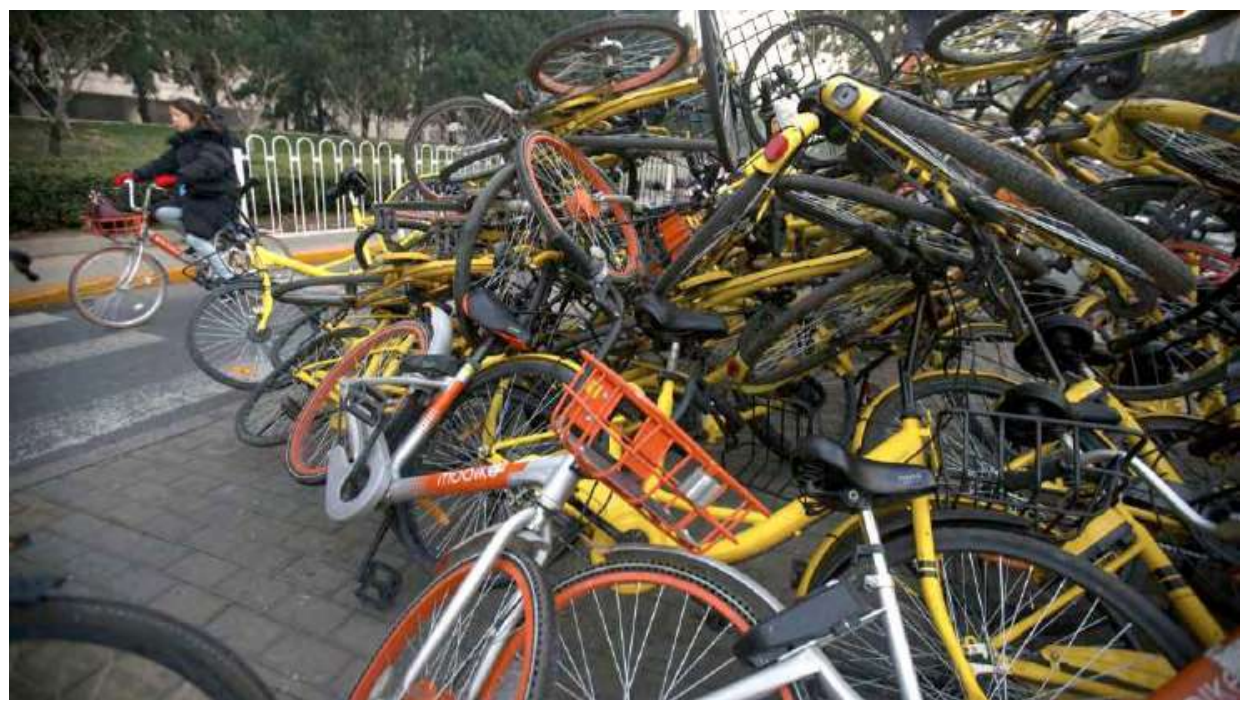

Foto 14 | Excesso de bicicletas de diferentes empresas bloqueando a calçada na China Fonte: Mark Schiefelbein (ITDP, 2018a) 


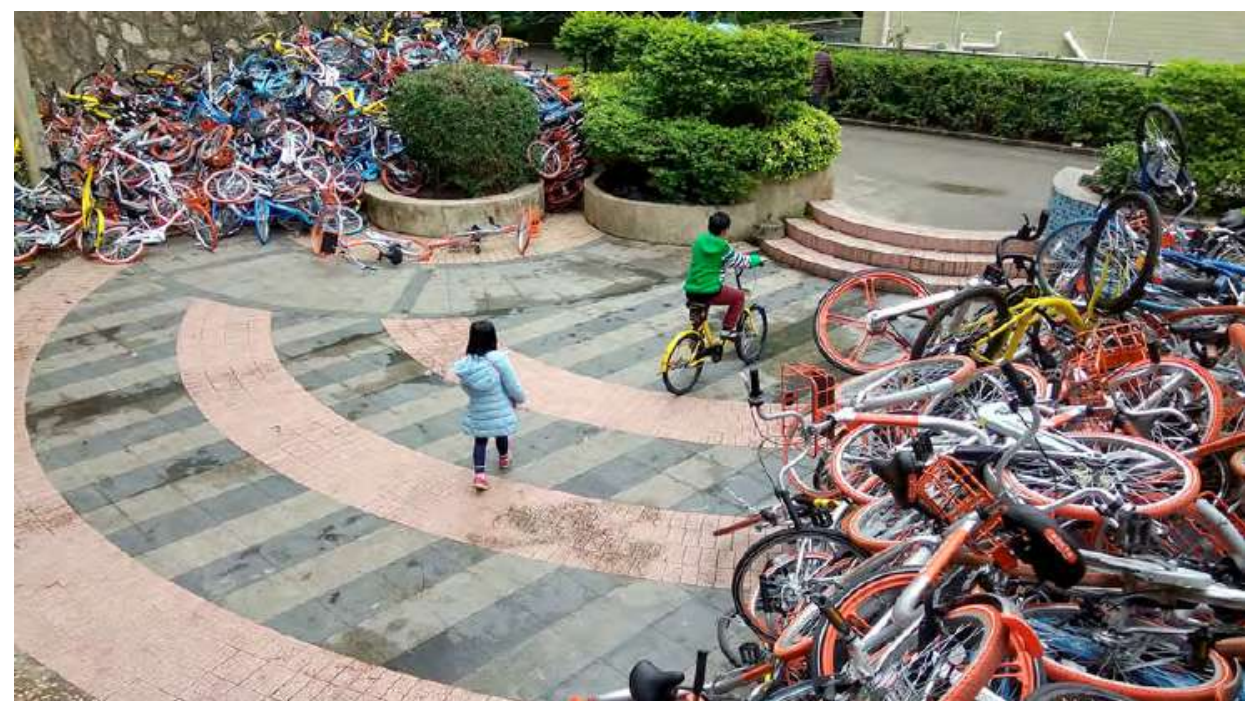

Foto 15 | Bicicletas dockless de diferentes empresas na entrada do parque Xiashan em Shenzhen (China), em janeiro de 2017: problema da superlotação no espaço público Fonte: AFP / Getty. TAYLOR (2018).

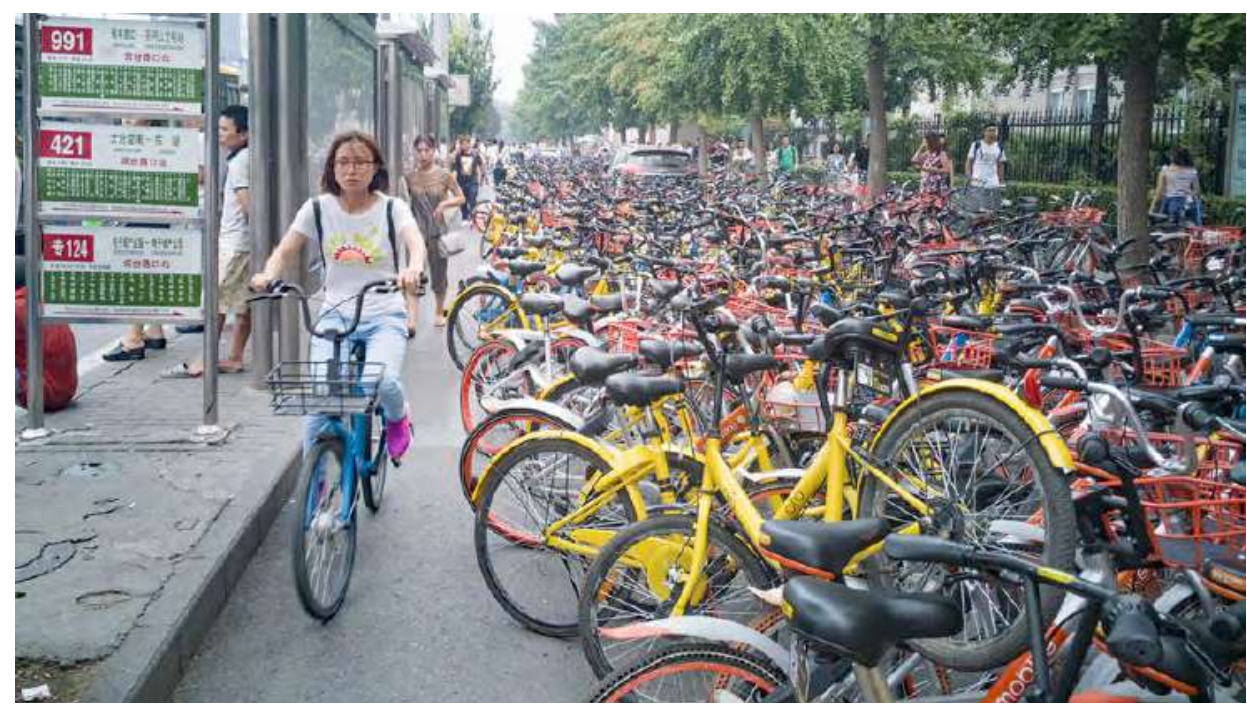

Foto 16 | Bicicletas dockless atrapalham caminho em Beijing (China), em janeiro de 2017 Fonte: Zhangjin_net/Shutterstock. TAYLOR (2018). 


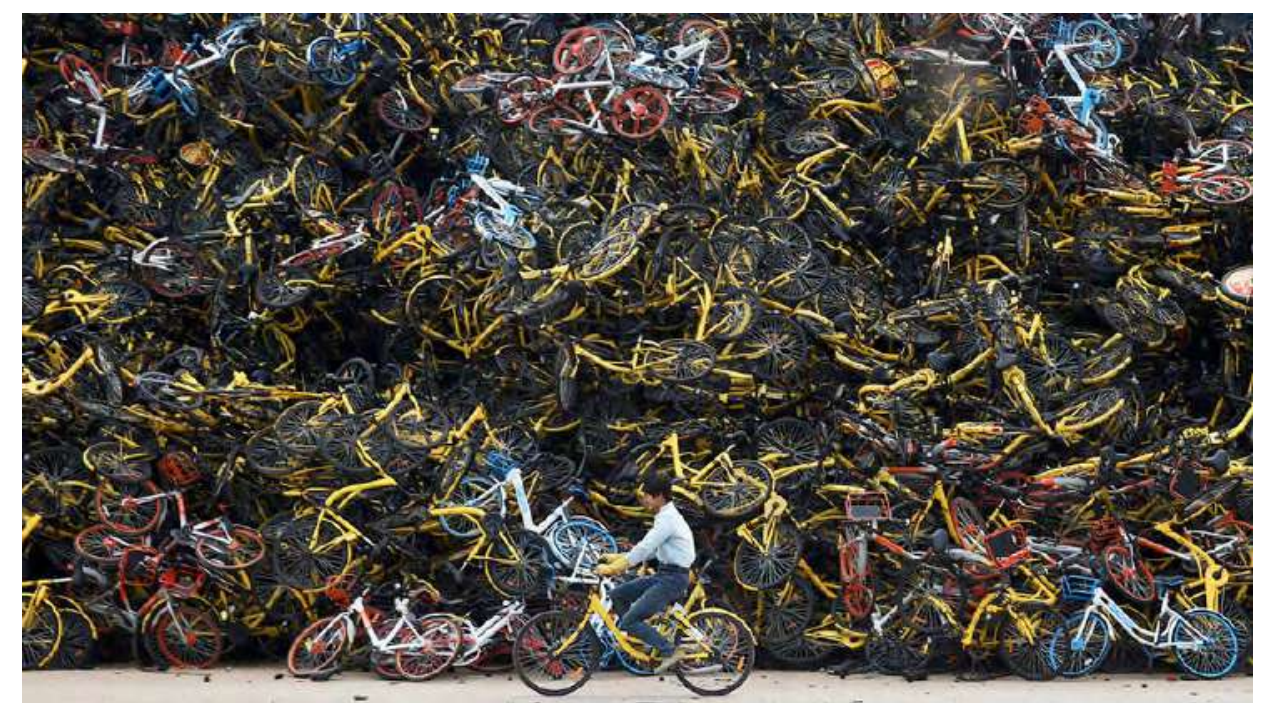

Foto 17 | Trabalhador pedala a bicicleta compartilhada ao lado da pilha de bicicletas inutilizadas em um terreno baldio em Xiamen (China), em dezembro de 2017 Fonte: Reuters. TAYLOR (2018).

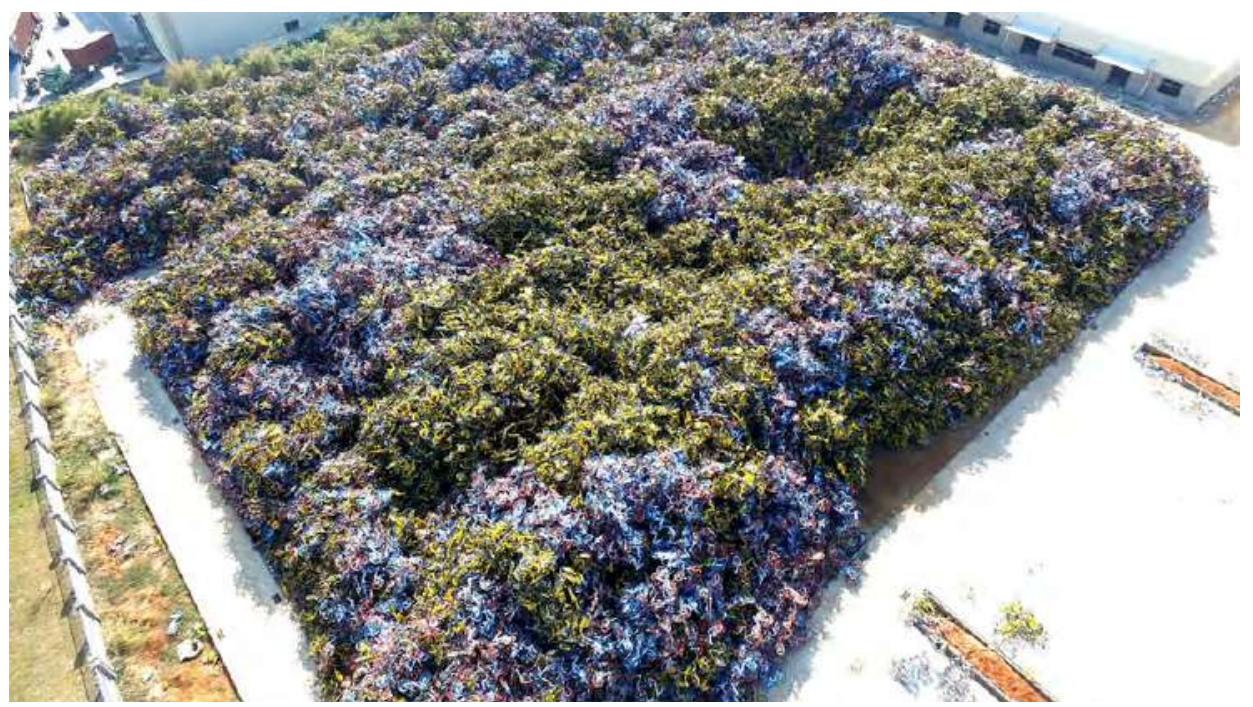

Foto 18 | Cemitério de bicicletas na China: problema de descarte e baixa durabilidade e manutenção, em janeiro de 2018, em Xiamen (China) Fonte: TPG / Getty. TAYLOR(2018). 


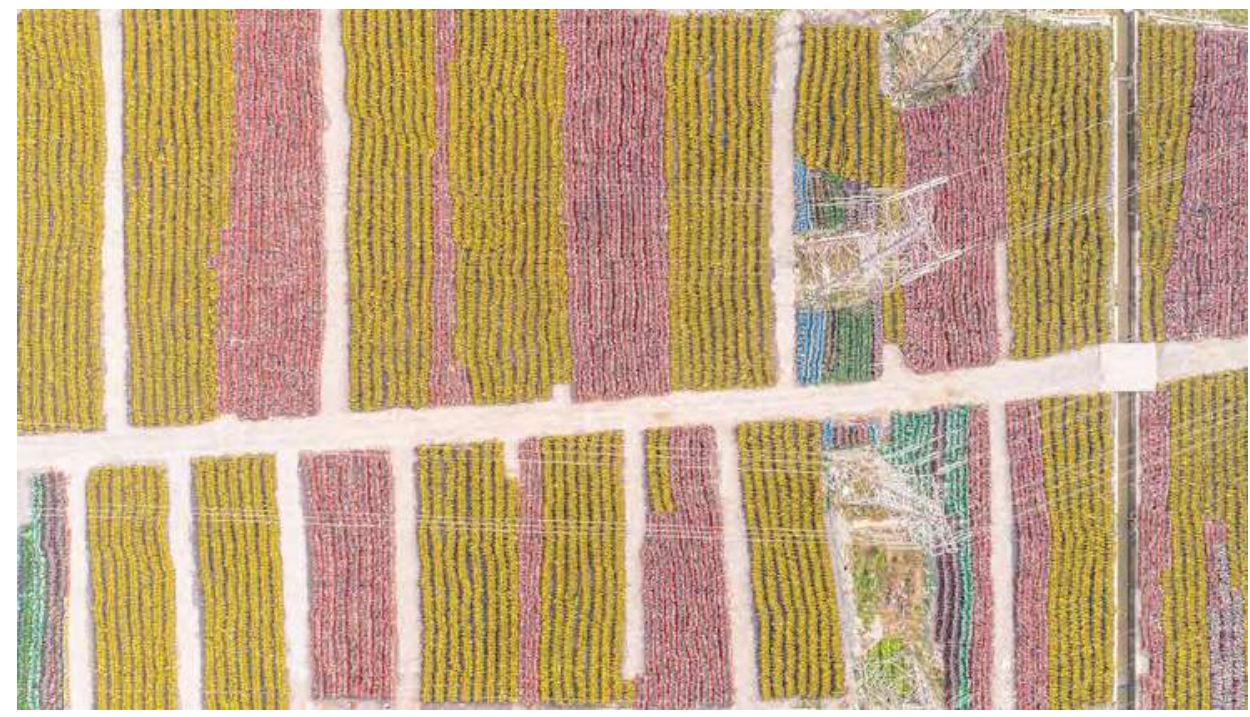

Foto 19 | Milhares de bicicletas dockless inutilizadas em campo próximo de Shanghai Fonte: Yibo Wang/Shutterstock. TAYLOR (2018).

A grande quantidade de investimento possibilitou o crescimento dos sistemas, tanto na China, quanto na Europa, Austrália e América do Norte. Segundo ITDP (2018a), em 2017, a empresa Ofo levantou US \$ 700 milhōes, enquanto a Mobike levantou US \$ 600 milhôes em financiamento de capital de risco: em conjunto, ambas empresas já levantaram US $\$ 2.2$ bilhōes de capital. No entanto, năo é claro se as empresas de sistemas dockless serăo viáveis financeiramente a longo prazo. Apesar de gerar receita com depósitos de usuários, taxas de uso, publicidade no aplicativo e talvez, até com os dados de usuários, considera-se incerto se o modelo de negócio é sustentável sem a contínua aplicaçâo de capital.

Após dois anos de investimento, ambas empresas continuam năo rentáveis. Em dezembro de 2018, surgiram rumores sobre a possível falência da Ofo (BLOOMERG NEWS, 2018). A Mobike foi comprada em abril de 2018 pela 
empresa Meituan, uma das maiores plataformas de serviços de e-commerce do mundo, e no início de 2018 retirou as operaçôes de cidades dos Estados Unidos e do Reino Unido (LEE, 2018).

A Bluegogo, a terceira maior empresa de bicicletas dockless fechou em novembro de 2017, sem conseguir realizar o reembolso aos clientes que haviam feito depósitos para uso do sistema, e dessa forma, foram impossibilitados de reciclar ou doar as mais de 70.000 bicicletas dockless abandonadas ${ }^{17}$ (FORTUNATI, 2018).

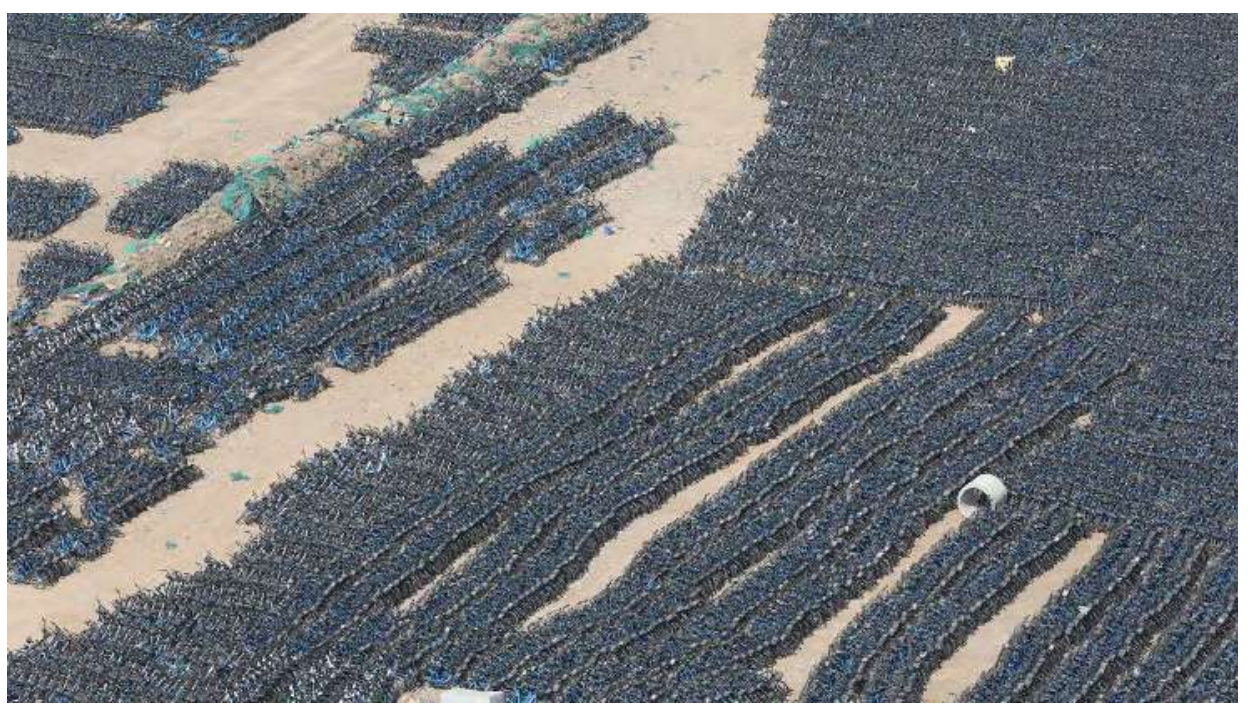

Foto 20 | Bicicletas abandonadas da Bluegogo após falência Fonte: EPA/WU HONG.

17 Como as bicicletas possuem peças não convencionais para evitar o roubo, a manutenção necessária no caso da doação para uso próprio por comunidades carentes é dificultada. 
Em 2017, cidades chinesas, já com milhares de bicicletas dockless em operaçấo, começaram a explorar opçôes de regulamentaçăo, como controle da dimensăo da frota (para evitar a superlotaçăo das bicicletas), regras de organizaçăo no espaço público e garantia ao usuário tanto da segurança, quanto da privacidade de dados. Algumas cidades chinesas inclusive já proibiram a entrada de novas bicicletas nas cidades (BBC NEWS, 2017). Essa necessidade surgiu após a experiência dos problemas apresentados pela operaçăo de sistemas sem regulamentaçăo, pois o serviço ineficiente degrada a imagem e o potencial do compartilhamento de bicicletas dockless.

Apesar da maioria de as cidades năo financiarem os sistemas, sua operaçâo depende do uso do espaço público de calçadas, praças e leitos carroçáveis. O estabelecimento de regras para a licença de funcionamento pode ajudar a alcançar a integraçăo modal e acessibilidade, assim como a definiçăo de objetivos operacionais propicia a organizaçăo efetiva do espaço público, almeja a equidade, aprimora o planejamento da mobilidade urbana, garante elevados níveis de serviços e protege os usuários (ITDP, 2018c).

Segundo o ITDP (2018a), os governos precisam assumir papel mais ativo na regulamentaçăo dos sistemas, embora a operaçâo seja realizada por empresas privadas, pois dependem de infraestrutura pública na qual já existe conflito pelo espaço limitado.

Com a expansăo do sistema dockless fora da China, a partir de 2017, as cidades começam a se preparar para o impacto, com intuito de năo cometerem os mesmos erros dos exemplos chineses. Nos Estados Unidos, Seattle e Săo Francisco estabeleceram exigências de autorizaçăo para os operadores privados, relacionadas à segurança, estacionamento e compartilhamento 
dos dados dos usuários. Em outros casos, como em Washington DC e Dallas, foi permitida a entrada de diversas empresas de dockless com regulamentaçăo limitada, a fim de criar regras baseadas no comportamento observado durante o projeto piloto ITDP (2018a).

Recentemente, no Brasil, a Prefeitura de Vila Velha (Espírito Santo) apreendeu 130 bicicletas da operadora Yellow e multou em R\$120.000,00, ao alegar que foram deixadas nas ruas da cidade, no dia oito de fevereiro de 2019, sem autorizaçăo (DIAS, 2019).

Em 2017, o número de bicicletas compartilhadas nos Estados Unidos mais que dobrou, de 42.500 para 100.000 , dos quais $76 \%$ do incremento foi por bicicletas dockless enquanto $24 \%$ de bicicletas compartilhadas com estaçôes (NACTO, 2017).

Segundo o gráfico 9, apesar da quantidade de bicicletas compartilhadas dockless e bicicletas compartilhadas com estaçôes apresentarem quase a mesma quantidade, a relaçăo de viagens realizadas pelos dois tipos de sistema é muito diferente. As bicicletas com estaçôes representam 56\% da frota total americana e foi responsável por $96 \%$ das 35 milhôes de viagens totais de 2017. 


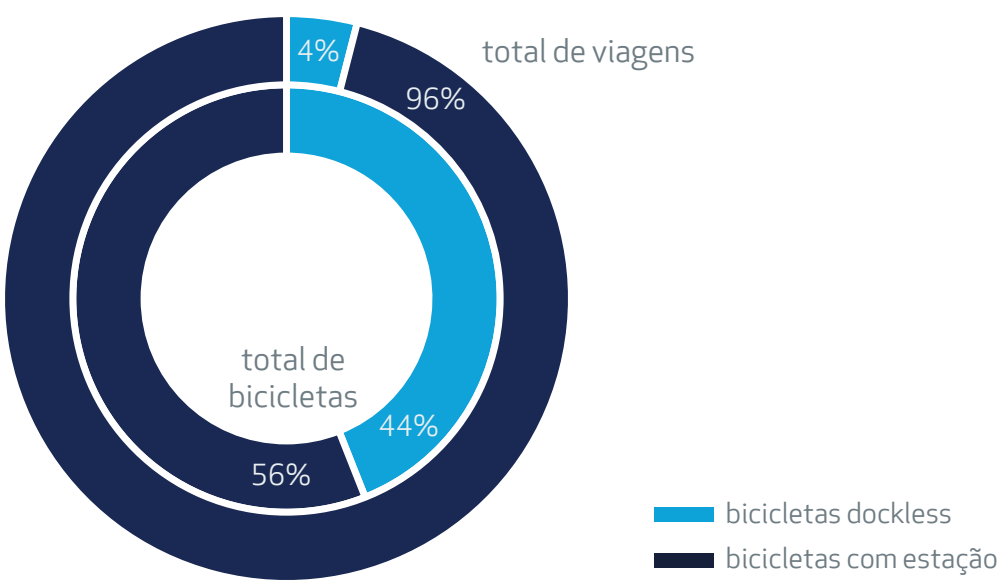

Gráfico 9 | Comparação do número de bicicletas compartilhadas dockless e com estação, com as respectivas quantidades de viagens realizadas nos Estados Unidos em 2017

Fonte: NACTO, 2017. Elaboração própria.

Essa discrepância pode ser explicada pela média mais alta de viagens por dia por bicicleta de sistemas com estaçôes, quando comparada à média de sistemas dockless. Segundo a NACTO (2017), os sistemas americanos com estaçōes possuem a média de 1,7 VDB, enquanto que o sistema dockless apresenta apenas 0,3 VDB.

NACTO (2017) revela que é possível identificar comportamentos diferentes dos sistemas com e sem estaçôes. Geralmente, sistemas com estaçōes apresentam maior uso durante a semana e possuem dois picos bem demarcados de uso no início da manhâ e no final do dia (gráfico 10), e caracterizam o sistema como parte da rede pública de transporte, incorporada no cotidiano da populaçăo urbana como modo de deslocamento para trabalho ou estudo. 


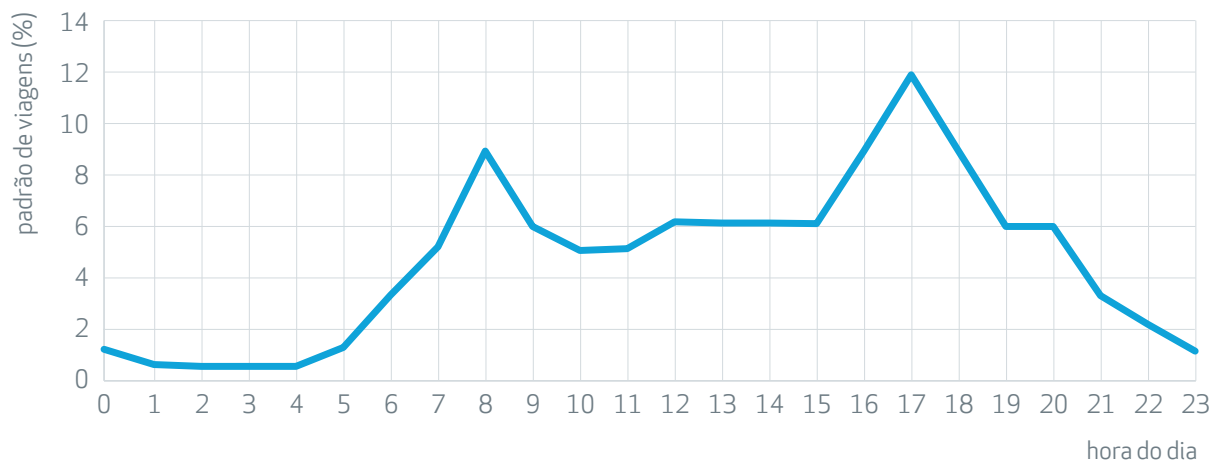

Gráfico 10 | Padrão de viagens por horário do dia em sistema de bicicletas compartilhadas com estação

Fonte: NACTO, 2017.

Já, o sistema dockless de Seattle possui apenas o pico de uso no final da tarde, e as viagens săo distribuídas ao longo do dia, com uso mais acentuado no final de semana, e sugerem viagens com motivo recreacional. O padrăo reconhecido no gráfico 10 será visível nos dados de uso do Bike Sampa, no capítulo 3. 


\subsubsection{Bicicleta elétrica}

Os sistemas de compartilhamento de bicicletas elétricas, chamadas e-bikes, cujos pedais săo auxiliados por um motor elétrico, săo úteis por contribuir com o conforto do usuário, ao reduzir o esforço do pedalar; algumas barreiras geralmente citadas para o ciclismo, como topografia acidentada, viagens de longa distância, fadiga e sudorese, ampliam o alcance e a gama de destinos (GUIA GLOBAL DE DESENHO DE RUAS, 2018).

Alguns sistemas como o Ecobici (Cidade do México), adicionaram 28 estaçôes capazes de carregar as novas bicicletas elétricas compartilhadas ao projeto já existente no começo de 2018, com a limitaçăo de que bicicletas elétricas devem ser retiradas e devolvidas apenas em estaçōes específicas.

Em janeiro de 2019, iniciou-se a substituiçăo da tecnologia das estaçôes de compartilhamento de Barcelona do sistema Bicing ${ }^{18}$, que irá oferecer estaçôes mistas, nos quais será possível encontrar e devolver tanto bicicletas mecânicas quanto elétricas. O serviço terá 425 estaçôes mistas para 6.000 bicicletas mecânicas e 1.000 bicicletas elétricas ${ }^{19}$.

18 A nova tecnologia é da empresa canadense chamada PBSC Urban Solutions, a mesma utilizada em alguns sistemas brasileiros, como em São Paulo e no Rio de Janeiro.

19 Informações encontradas do site do sistema Bicing. Disponível em: $<$ www.bicing.barcelona>. Acesso em: 20 jan. 2019. 


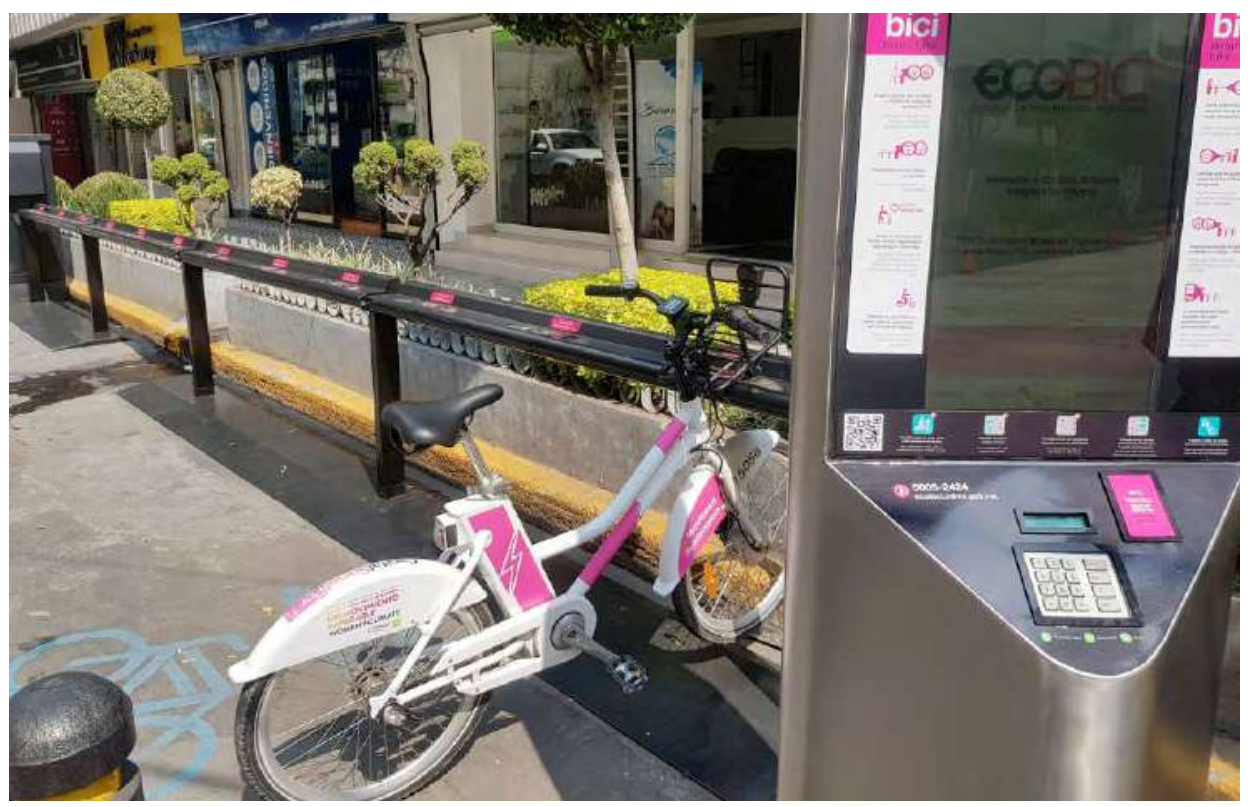

Foto 21 | Estação de bicicleta elétrica na Cidade do México (Ecobici), 2018

Fonte: Elias Pelcastre.

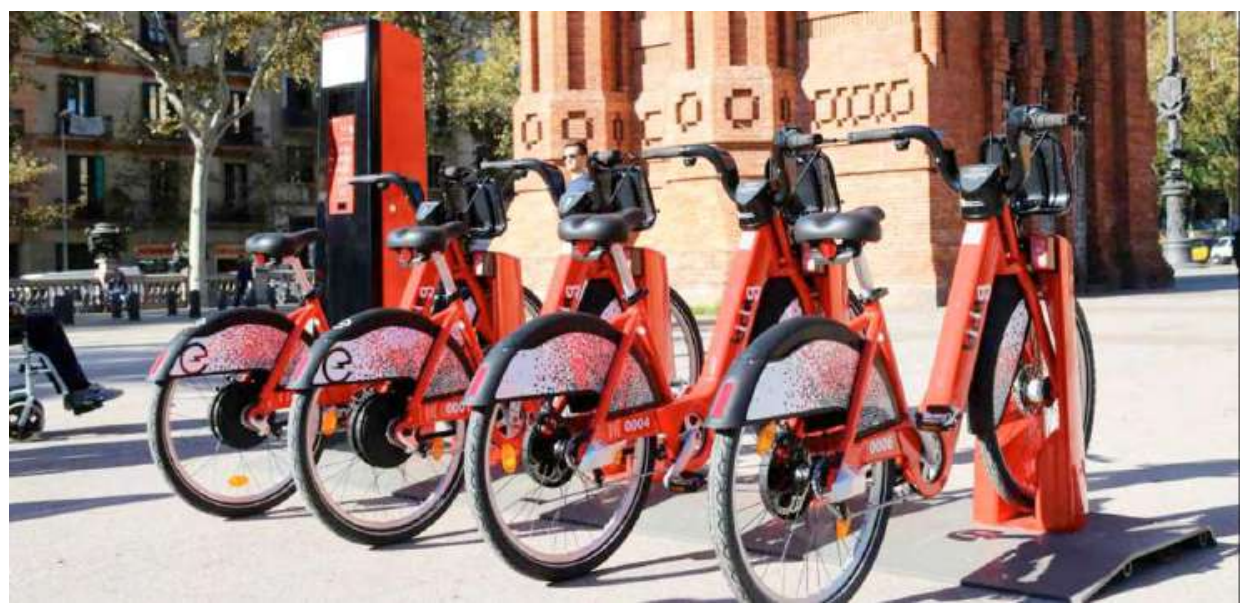

Foto 22 | Nova estação de bicicleta mista em Barcelona (Bicing), 2019

Fonte: Bicing. 
Além dos sistemas baseados em estaçôes, que possibilitam, para o compartilhamento de bicicletas elétricas, pontos físicos de recarga da bateria, há também os sistemas dockless elétricos, lançados em cidades dos Estados Unidos ,a partir de 2017. Em Sâo Francisco, usuários da Uber podem alugar bicicletas elétricas de pedal assistido dockless, chamadas de Jump Bikes, com o aplicativo da Uber. Essa integraçăo tecnológica de serviços de compartilhamento de bicicletas e de caronas apresenta interessante implicaçâo para a mobilidade compartilhada e mobilidade como serviço ${ }^{20}$. As bicicletas dockless Jump possuem sistema híbrido com cadeados em “U” próprios, que devem ser travados em paraciclos públicos na cidade em sua devoluçăo. Essa característica do sistema contribui para a organizaçăo do espaço público, e evita o estacionamento das bicicletas em locais inadequados.

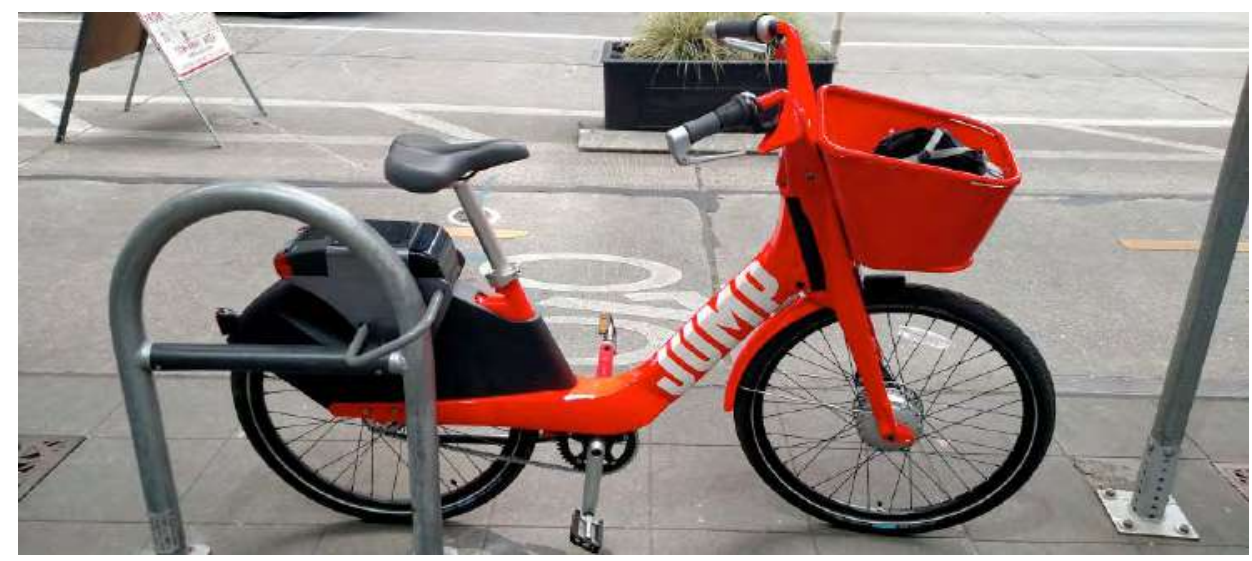

Foto 23 | Bicicletas dockless elétricas Jump, travadas com seu cadeado em paraciclo Fonte: Doug Trumm.

20 Mobilidade como serviço é a tradução do termo em inglês Mobility as a Service (MAAS), que possui o objetivo de reduzir as barreiras aos modos de mobilidade de compartilhamento, ao facilitar aos usuários a integração modal por meio do aplicativo, e oferecer assim, alternativas eficientes ao uso do veículo particular. 
A análise dos dados de viagens de carro Uber e de bicicleta elétrica Jump pelo aplicativo da Uber feita por Santosh Rao (2018), pesquisador da Uber, revela que, durante o horário de pico do congestionamento, o uso das bicicletas é maior que o dos carros, a representar diminuiçăo em 15\% do número de viagens, e conclui que os dois modos sâo complementares ao longo do dia, pois a situaçâo é invertida no período noturno, com maior quantidade de viagens de carro Uber (gráfico 11).

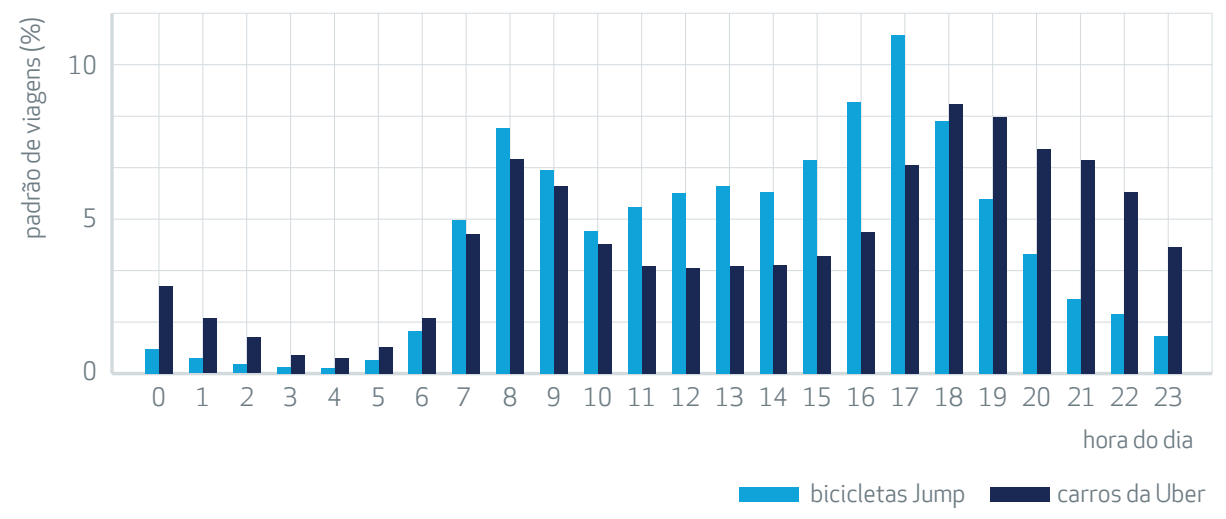

Gráfico 11 | Relação do uso diário de bicicletas elétricas Jump e carros Uber, em São Francisco Fonte: Santosh Rao, Uber. Elaboração própria.

Há a discussăo atual a respeito do sistema dockless que nâo necessita de pontos físicos dispostos na cidade para o compartilhamento; entretanto, ao introduzir a questăo do veículo elétrico, as localizaçôes físicas voltam a entrar na pauta com importância, pois seriam os locais para o carregamento das baterias, por auxiliar o trabalho da operaçáo para a troca e carregamento na oficina. Sistemas como o da Jump, que năo possuem pontos físicos para carregamento da bateria, dependem da operaçấo da empresa para realizar a retirada das bicicletas descarregadas, carregamento e devoluçăo ao sistema, o que encarece o custo de manutençăo do serviço. 
Será necessário analisar os dados por mais tempo para entender como ocorre a migraçăo do serviço de caronas com a Uber para as bicicletas elétricas compartilhadas, e se isso é facilitado por estar no mesmo aplicativo ou se o padrăo acontece em outras cidades, com serviços tanto de compartilhamento de bicicletas quanto de caronas de aplicativo.

\subsubsection{Patinete elétrico dockless}

O primeiro sistema de compartilhamento dockless de patinetes elétricos foi inaugurado no final de 2017, nos Estados Unidos, pela empresa Bird, e provocou desde alegria nostálgica nos usuários, as preocupaçôes com a segurança e ódio total ao sistema. A rápida adesâo ao uso do patinete elétrico na cidade propiciou a guinada de muitas empresas de bicicletas compartilhadas ao oferecer o sistema, além do surgimento de empresas concorrentes. $O$ elevado número de viagens configura o modelo de negócio do patinete elétrico dockless mais viável que as bicicletas dockless, pago em algumas semanas, em lugar de meses (ITDP, 2018d). 


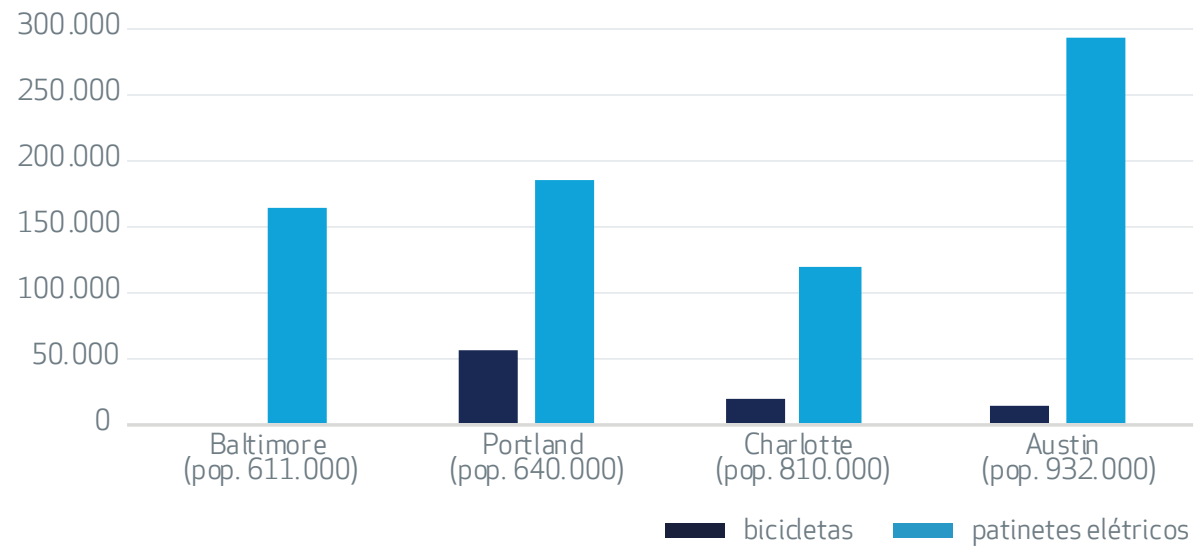

Gráfico 12 | Comparação das viagens mensais do sistema de bicicletas e patinetes elétricos ${ }^{21}$ dockless em quatro cidades americanas

Fonte: ITDP (2018d). Elaboração própria.

Dessa forma, houve atraçăo de muitos fundos de capital de risco, e em menos de um ano de operaçấo, Bird tornou-se a empresa mais rápida a atingir a avaliaçâo de US\$̦ 1 bilhăo, mais que Uber, Facebook e Twitter. No entanto, existem preocupaçôes sobre a sustentabilidade a longo prazo do modelo financeiro, como no caso da bicicleta dockless, pois custos operacionais associados ao serviço de alta qualidade devem ser considerados, referentes à manutençăo, carregamento das baterias e rebalanceamento.

Com o objetivo de reduzir o custo de operaçăo de recarga dos patinetes elétricos, a maioria das empresas oferecem o serviço de "carregador" de bateria. É possível realizar o cadastro no aplicativo, receber treinamento e realizar o carregamento da bateria por um valor determinado pela empresa. Além disso, costuma-se cobrar multa para aqueles que devolvem o patinete

21 Patinete elétrico dockless chama-se scooter em inglês 
fora da área de cobertura determinada pelo sistema, para amenizar os custos de rebalanceamento.

No final de 2018, as empresas começaram a expandir o sistema para outras regiôes. Lime opera em seis cidades europeias, na Nova Zelandia e na Cidade do México, onde também há operaçăo da empresa mexicana Grin, que recentemente iniciou em Săo Paulo. A Bird, também opera em seis cidades europeias, como Londres, Madrid e Paris, assim como em Israel (ITDP, 2018d).

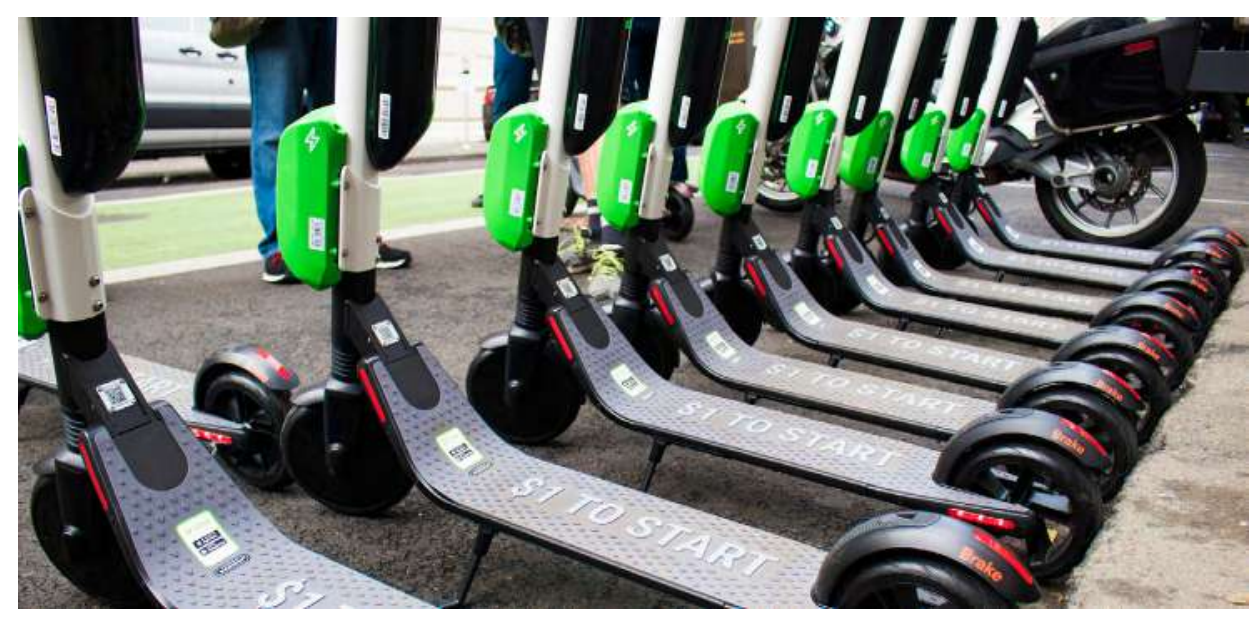

Foto 24 | Patinetes elétricos da Lime em Portland (Estados Unidos) Fonte: ITDP (2018d), PBOT Flickr. 


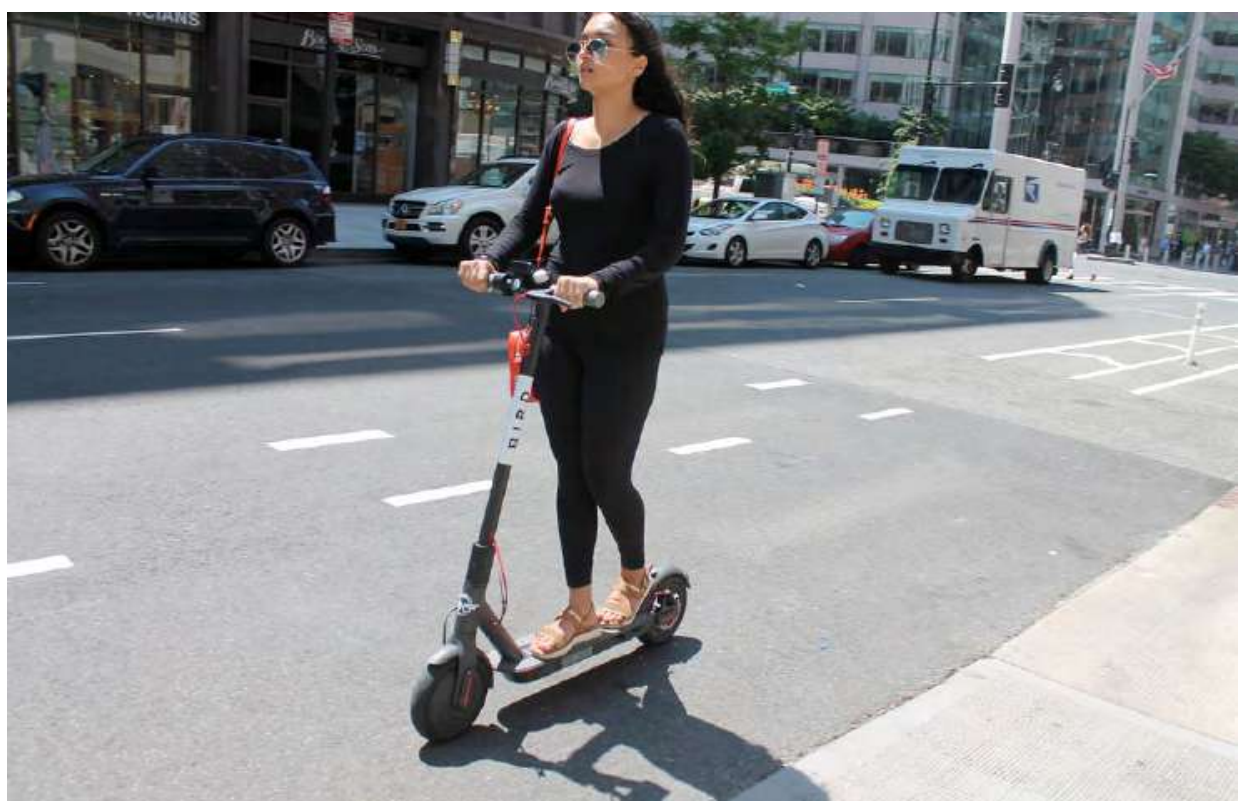

Foto 25 | Usuária do patinete elétrico Bird em Washington DC

Fonte: ITDP (2018d).

Assim como no caso das bicicletas dockless, os patinetes também sâo deixados nas calçadas e atrapalham o espaço do pedestre. 0 problema é um pouco menor, por ocuparem menos espaço que as bicicletas.

Regulamentaçōes do poder público começaram a organizar o estacionamento, para evitar esse tipo de conflito.

Devido à elevada taxa de roubo dos patinetes elétricos dockless Scoot, em Sâo Francisco (nos Estados Unidos), no início de operaçăo, foi desenvolvido o mecanismo de trava em local fixo (como paraciclos), que além de reduzir o índice de vandalismo, evita o estacionamento em locais inadequados (DICKEY, 2018). 


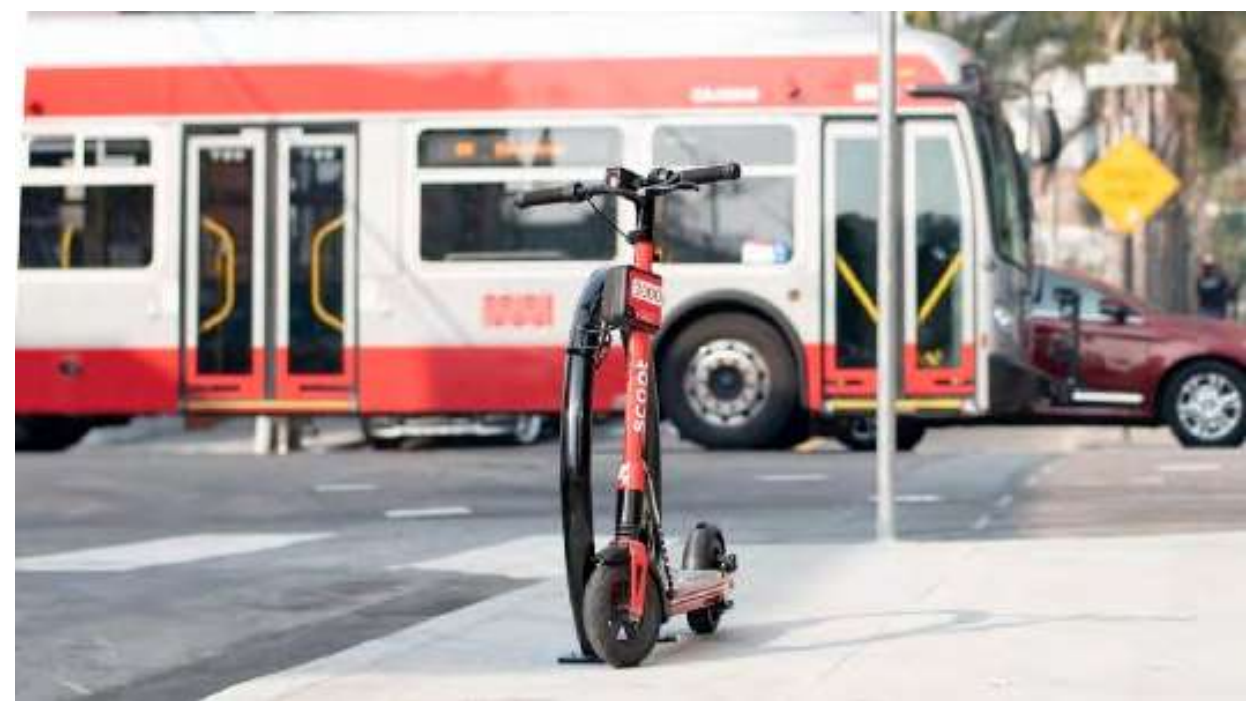

Foto 26 | Patinete elétrico Scoot travado em suporte fixo, em São Francisco

Fonte: Scoot.

O tema da segurança dos usuários do patinete elétrico dockless, assim como dos pedestres gerou polêmica há pouco tempo, nos Estados Unidos, após a ocorrência de colisōes fatais. Alguns caracterizaram o acontecimento como crise de segurança pública, e uma açâo judicial foi apresentada em nome dos pedestres feridos às empresas por negligência. Algumas cidades passaram a limitar a velocidade máxima para 10 milhas por hora (aproximadamente 16 quilômetros por hora). Entretanto, o ITDP (2018d) questiona se essa náo representa uma reaçăo exagerada, pois utilizar o modal traz certo nível de risco, mas estes săo mínimos quando comparados aos perigos associados a dirigir um carro ou dividir a rua com veículos em alta velocidade.

Em Washington, o Departamento Distrital de Transportes (District Department of Transportation, DDOT, 2018) realizou estudo para comparar o uso do SPBC com estaçâo (Capital Bikeshare), o sistema dockless de 
bicicletas e de patinetes elétricos (scootershare). Nâo se observa variaçăo do uso do sistema Capital Bikeshare com a introduçăo dos novos modais, apenas o impacto do clima frio, entre os meses de novembro de 2017 e março de 2018, a ocasionar diminuiçăo do uso dos dois sistemas de bicicleta e concluir que mais pessoas começaram a realizar seus deslocamentos em modos ativos e compartilhados. É visível, no entanto, a alta adesâo no uso dos patinetes elétricos a partir de abril, logo depois do início de funcionamento e o aumento do número de acidentes, demonstrado no gráfico 13.

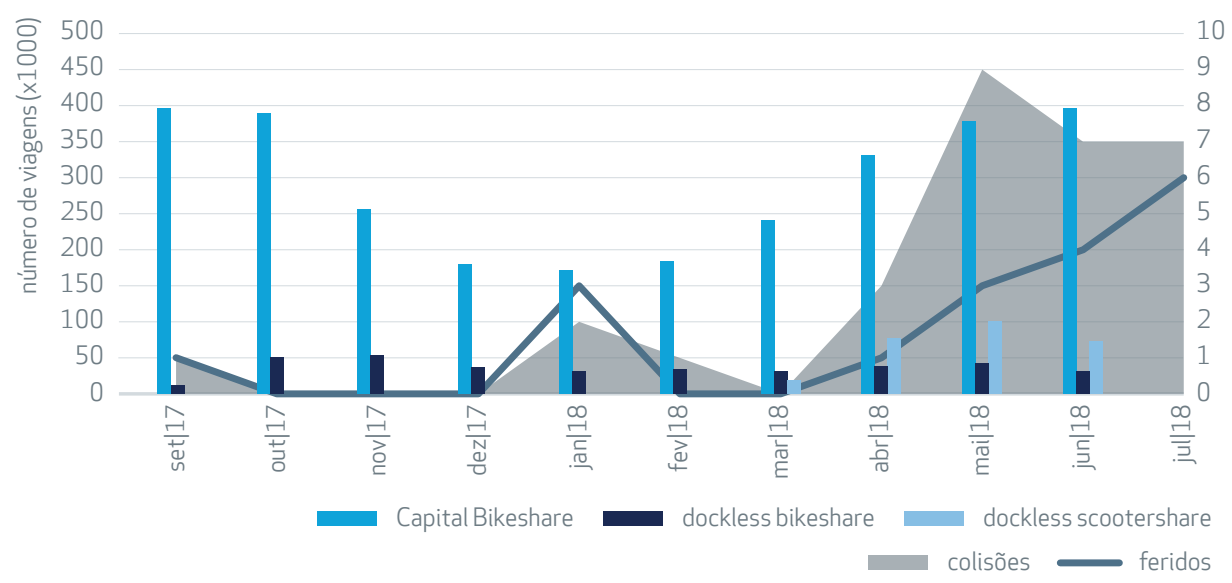

Gráfico 13 | Número de viagens dos diferentes modais e o número de acidentes e colisões, no período piloto de bicicletas e patinetes elétricos dockless em Washington Fonte: DDOT (2018, p. 18 e p. 27). Elaboração própria.

O investimento em infraestrutura cicloviária é essencial para garantir a segurança e inclusâo de diferentes modais de transporte. A popularidade dos patinetes elétricos dockless demonstra a necessidade de diversificaçăo nas opçôes de transporte, para além dos automóveis, principalmente no último quilômetro do deslocamento. As pessoas querem se locomover pelas cidades de outras formas e os governos deveriam se esforçar para tornar essas opçōes convenientes, seguras e conectadas. 
Segundo o ITDP (2018b), os patinetes elétricos dockless apresentam o potencial de reduçăo de viagens de curta distância realizadas por veículos de ocupaçăo única e de caronas (como Uber, 99 Taxi, Cabify), ao reduzir o congestionamento urbano e as emissóes de poluentes, quando oferecem mobilidade flexível, principalmente como forma de evitar o trânsito, e de baixo custo ${ }^{22}$. Além disso, poderiam contribuir com o acesso ao sistema de transporte público de massa, ao aumentar o PNT das cidades e ao trabalhar com integraçăo de tarifa na intermodalidade, para torná-lo viável financeiramente aos usuários.

O sistema é muito recente, e apenas o tempo poderá demonstrar, com os dados de uso, se os patinetes elétricos dockless conseguem promover a conexăo do primeiro e último quilômetro ao transporte público, e se a migraçăo para o patinete elétrico acontece a partir da substituiçăo das viagens de carro, do transporte público (metrô, trem e ônibus), ou afastam os pedestres e ciclistas da caminhada e pedalada.

Para viabilizar a implantaçăo dos sistemas, muitas cidades estăo regulamentanto o funcionamento dos patinetes elétricos dockless após períodos pilotos para o teste dessas regras e a integraçăo com a rede de transporte público. Outras cidades começaram a solicitar contribuiçâo das empresas privadas de compartilhamento para a construçâo de infraestrutura cicloviária.

22 Baixo custo quando comparado a viagens feitas com carro ou por aplicativo de carona, pois é mais caro que o transporte público e o sistema de compartilhamento de bicicletas (tabela 3). 
(...) this new model of collaboration between cities and private companies to fund projects that make choosing a scooter or bike as a last-mile solution safer could prove successful, as long as cities are clear about what their goals are and why they are asking companies to share costs (ITDP, 2018b). ${ }^{23}$

No entanto, as empresas privadas revelam que a regulamentaçăo pode prejudicar a viabilidade do sistema. A empresa Grin, em outubro de 2018, suspendeu o serviço na Cidade do México após as regulamentaçōes impostas pelo poder público que solicitavam o cumprimento de todos os requisitos constantes na Lei de Mobilidade. Entre eles, demanda-se a apresentaçâo dos dados do representante legal da empresa, proposta técnica de operaçăo e a realizaçăo de apólice de seguro com cobertura ampla para proteçăo do usuário (SOLÍS, 2018).

No Brasil, os patinetes chegaram no segundo semestre de 2018, com três empresas em Sáo Paulo (Yellow, Grin ${ }^{24}$ e Scoo) e uma empresa no Rio de Janeiro. A Tembici, com patrocínio da Petrobras Distribuidora, está disponível exclusivamente na zona sul do Rio de Janeiro, com funcionamento a partir de pontos físicos para retirada e devoluçâo, indicados no aplicativo, localizados na orla, na lagoa e em alguns Postos Petrobras.

23 (...) esse novo modelo de colaboração entre cidades e empresas privadas para financiar projetos que tornam a escolha de um patinete elétrico ou bicicleta uma solução de última milha mais segura pode ser bem-sucedida, desde que as cidades sejam claras sobre seus objetivos e sobre o por que estão solicitando às empresas a compartilhar custos (tradução nossa).

24 As empresas Grin e Yellow anunciaram fusão em 30 de janeiro de 2019. 


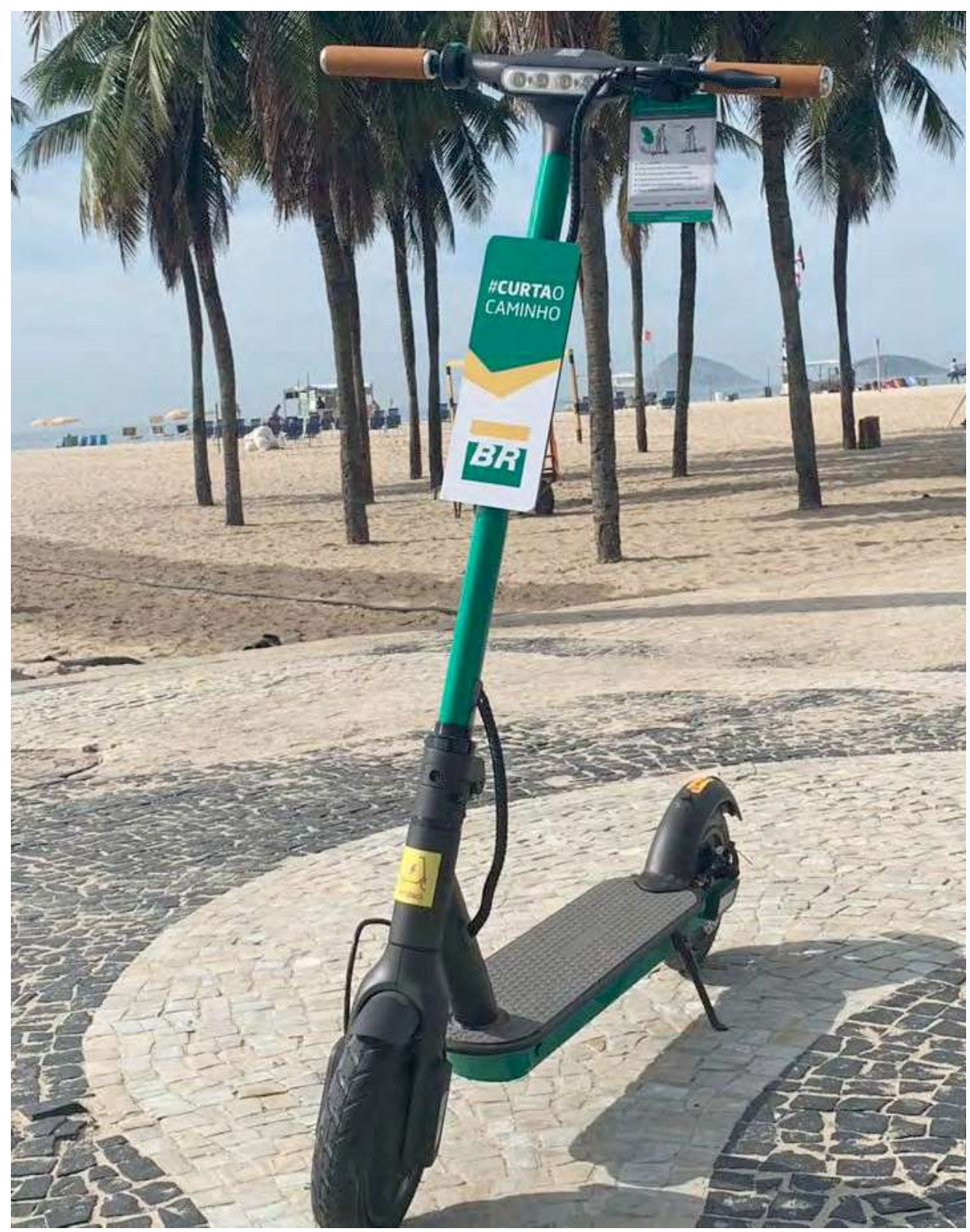

Foto 27 | Patinete Petrobras, no Rio de Janeiro, operado pela Tembici Fonte: Ciclovivo 
Apesar do maior alcance dos modelos elétricos, tanto dos tipos de usuários quanto da distância das viagens, săo sistemas mais caros que o transporte público ${ }^{25}$ e que as bicicletas compartilhadas; porém, geralmente, mais baratos que o uso de táxi e caronas de aplicativo (como Uber e 99 Taxi).

\begin{tabular}{|c|c|c|c|c|}
\hline $\begin{array}{l}\text { Modal de } \\
\text { compartilhamento }\end{array}$ & $\begin{array}{l}\text { Bicicleta mecânica de } \\
\text { sistemas com estação }\end{array}$ & $\begin{array}{l}\text { Bicicleta } \\
\text { dockless }\end{array}$ & $\begin{array}{l}\text { Patinete } \\
\text { elétrico }\end{array}$ & $\begin{array}{l}\text { Bicicleta } \\
\text { elétrica }\end{array}$ \\
\hline Custo do plano & $\mathrm{R} \$ 2,00$ por 60 minutos & $\begin{array}{l}\mathrm{R} \$ 1,00 \text { a cada } \\
15 \text { minutos }\end{array}$ & $\begin{array}{c}\mathrm{R} \$ 3,00 \text { para } \\
\text { desbloqueio e } \\
\mathrm{R} \$ 0,50 \text { a cada } \\
\text { minuto }\end{array}$ & $\begin{array}{c}\mathrm{R} \$ 7,50[1] \\
\text { nos primeiros } \\
30 \text { minutos e } \\
\mathrm{R} \$ 0,26 / \mathrm{min} \\
\text { adicional }\end{array}$ \\
\hline $\begin{array}{l}\text { Custo de uma viagem } \\
\text { de } 15 \text { minutos }\end{array}$ & De $R \$ 0,60$ a R $\$ 2,00$ [2] & $\mathrm{R} \$ 1,00$ & $\mathrm{R} \$ 10,50$ & $\mathrm{R} \$ 7,50$ \\
\hline
\end{tabular}

Tabela 3 | Valor médio do custo de uma viagem de 15 minutos nos diferentes modais de compartilhamento, em São Paulo

[1] Valor de referência da Jump em São Francisco. Cotação do dólar de 18 jan. 2019. [2] Variação devido ao valor do plano de assinatura e da quantidade de viagens realizadas nesse perído. Os planos serão detalhados no capítulo 3.

Fonte: informações nos sites das empresas Tembici, Yellow, Grine Jump, emjaneiro de 2019.

\begin{tabular}{|c|c|c|c|}
\hline Aplicativo de carona & Uber & 99 Taxi (pop) & 99 Taxi (taxi comum) \\
\hline $\begin{array}{c}\text { Custo aproximado da viagem } \\
\text { de um percurso de } 5 \mathrm{~km}[1]\end{array}$ & $\mathrm{R} \$ 16,00$ & $\mathrm{R} \$ 18,70$ & $\mathrm{R} \$ 38,50$ \\
\hline
\end{tabular}

Tabela 4 | Valor médio do custo de uma viagem de 5 km nos diferentes aplicativos de carona, em São Paulo

[1] Os modais elétricos alcançam, em 15 minutos de viagem, no máximo $5 \mathrm{~km}$, pois a velocidade máxima é de $20 \mathrm{~km} / \mathrm{h}$ em ciclovias e ciclofaixas. 0 cálculo do custo da viagem dos aplicativos de carona foi feita no dia 20 jan. 2019, domingo, às 18h, ou seja, horário sem congestionamento. Fonte: informações nos aplicativos das empresas Uber e 99 Táxi, em janeiro de 2019.

25 Custo de uma viagem de ônibus na cidade de São Paulo é de R\$4,30, em janeiro de 2019. 
Apesar da alta adesâo inicial a todos esses sistemas de compartilhamento, principalmente aos elétricos, tanto por curiosidade e experimentaçăo, quanto por uso de lazer, deve-se entender o quanto o custo influencia na adoçâo diária dos deslocamentos.

Para compreensâo do real benefício para as cidades no uso desses sistemas, tanto com a diminuiçăo da poluiçấo e aumento do PNT (acesso à cidade), diminuiçấo de congestionamentos e compartilhamento mais equitativo do espaço urbano, é necessário identificar qual foi o modal substituído e que parcelas da populaçăo conseguiram de fato utilizá-los.

Segundo Yasbek e Cardozo (2019), estudo da Associaçăo Brasileira de Planejadores Financeiros (Planejar) revelou o custo anual, para o paulistano, dos diferentes modais de deslocamento, em distância média diária de 7,5 $\mathrm{km}$. O automóvel configura-se como o meio de transporte mais caro, seguido dos aplicativos de carona. Mesmo com o reajuste das passagens de transporte público, a sua integraçâo com a bicicleta foi considerada a alternativa mais econômica. 


\begin{tabular}{|c|c|}
\hline Modal & valor (R\$) \\
\hline carro & $\mathrm{R} \$ 20.552$ \\
\hline ônibus, metrô ou trem & $\mathrm{R} \$ 2.270$ \\
\hline aplicativo & $\mathrm{R} \$ 10.056$ \\
\hline transporte público + patinete & $\mathrm{R} \$ 5.438$ \\
\hline transporte público + bicicleta & $\mathrm{R} \$ 2.798$ \\
\hline bicicleta [1] & $\mathrm{R} \$ 1.056$ \\
\hline
\end{tabular}

Tabela 5 | Custo anual dos meios de transporte para o trajeto de 7,5km de ida e volta para o trabalho

[1] 0 custo da bicicleta, se considerado o plano anual do sistema Bike Itaú, seria R\$160,00. Fonte: Planejar. Elaboração Própria. 


\subsection{Considerações}

As intençóes originais do Provos a respeito do compartilhamento de bicicletas públicas, que a princípio causaram estranhamento e foram consideradas como loucura inviável tanto pela populaçăo quanto pelos políticos e urbanistas da época, ao longo do tempo se mostrar viáveis e importantes para a mobilidade urbana.

Todas as geraçóes de sistemas que se sucederam, com o aperfeiçoamento da tecnologia, dos equipamentos e da gestăo, foram possíveis a partir das experiências nas cidades, com reconhecimento dos acertos e correçăo dos diversos contratempos enfrentados. O rápido avanço de novas tecnologias inviabiliza a antecipaçâo dos problemas recentes que aparecem no ambiente urbano. Percebemos as gestôes municipais sem referência de qual atitude tomar, devido às inconveniências dos estacionamentos em locais inadequados e aos acidentes de trânsito, principalmente quanto à regulamentaçấo, aos investimentos na infraestrutura cicloviária, e à limitaçâo dos serviços oferecidos pelas empresas privadas.

A alta adesâo da populaçáo ao uso de modais de compartilhamento ativos reflete a demanda reprimida existente nas cidades para diferentes formas de deslocamento, além do automóvel. Os investimentos focados nos veículos individuais em muitas cidades năo se sustentam mais, e devem ser redirecionados, ao transporte público, aos modais ativos que complementam sua acessibilidade e à infraestrutura que viabiliza sua segurança e existência, ao compartilhar o espaço urbano. 
A intermodalidade é essencial nas grandes cidades, para expandir o acesso às estaçóes de transporte de massa e, portanto, para a inclusăo social e o direto à cidade. Para isso, săo necessários investimentos em infraestrutura cicloviária, com o intuito de viabilizar as conexôes próximas às estaçôes; incentivos ao alcance de modais de compartilhamento em outras regióes das cidades; a integraçâo e financiamento de tarifas, para contribuir com a inclusăo social; e a integraçăo por meio do aplicativo, com o objetivo de facilitar o uso de diferentes modais e trazer eficiência e conforto.

No entanto, essas açôes serấo realizadas somente quando o poder público considerar os modais ativos como parte da mobilidade urbana, e tomar atitudes na redistribuiçâo do espaço público urbano de modo mais equitativo. 



\subsection{A bicicleta no contexto brasileiro}

Até o fim do século XX, a bicicleta era considerada prioritariamente veículo para esporte e lazer e, năo havia políticas públicas de incentivo a seu emprego como meio de transporte. Ela năo exercia, portanto, papel de relevância nos deslocamentos nas cidades brasileiras.

Os Passeios Ciclísticos da Primavera que ocorreram a partir da década de 70 atestam o reconhecimento da bicicleta como veículo de lazer. Um artigo da Folha de S. Paulo de 1995 relata um desses eventos, que teve percurso de 15 quilômetros, com início e fim no Obelisco do Ibirapuera, e foi realizado pela fábrica de bicicletas Caloi e pela Secretaria Municipal de Esportes. No site da Caloi, na descriçấo da sua história desde o século XIX, comenta-se que sucedeu na década de 70 o primeiro Passeio da Primavera, que reuniu cerca de 80 mil pessoas.

Instituir a bicicleta como um modo de transporte na cidade de Sáo Paulo nunca foi prioridade como política pública ao longo das gestōes municipais, uma vez que bicicleta, até recentemente, năo havia se firmado como presença constante e crescente nos deslocamentos cotidianos da cidade (MALATESTA, 2014, p.84).

Nos anos 1970, com o aumento dos preços dos combustíveis durante a crise do petróleo, países europeus, entre os quais a Holanda, elegeram a bicicleta como alternativa de transporte frente à elevaçăo dos preços dos combustíveis. Nessa época, a Empresa Brasileira de Planejamento de Transportes (GEIPOT) publicou o Manual de Planejamento Cicloviário, e nos 
anos 80 muitas cidades elaboraram planos diretores de transportes urbanos que consideravam a melhoria das condiçóes de circulaçăo de ciclistas (MINISTÉRIO DAS CIDADES, 2007a).

Os estudos para a implantaçâo de infraestrutura cicloviária na cidade de Sâo Paulo iniciaram-se nos anos 1980, porém algumas das ciclovias previstas foram implementadas apenas nos anos 1990 ou 2000, como nas avenidas Sumaré, Pedroso de Morais, Juscelino Kubitschek e Inajar de Souza, tendo sido consideradas para esse projeto apenas as avenidas com maior espaço no canteiro central (MALATESTA, 2014).

Segundo o Caderno de Mobilidade Urbana Sustentável, os grandes centros urbanos brasileiros adotaram modelo de mobilidade que favoreceu o uso do veículo particular, o que colaborou para o espraiamento das cidades e a fragmentaçâo do espaço devido ao deslocamento dos carros. Tal opçâo contribuía com a atividade econômica e atendia aos interesses de montadoras, sindicatos operários e expectativas da classe média. “Dessa forma, cidades se estruturam e se desenvolvem para acolher, receber, abrigar o veículo particular e assegurar-lhe a melhor condiçâo possível de deslocamento nas áreas urbanas" (MINISTÉRIO DAS CIDADES, 2004, p. 22).

Ainda segundo Malatesta (2014), apenas em 1997, 31 anos depois da criaçâo do Código Nacional de Trânsito (1966), a nova legislaçâo de trânsito instituída pelo Código de Trânsito Brasileiro - CTB reconhece a bicicleta como veículo năo motorizado movido a propulsâo humana, legaliza tanto os deveres e direitos do ciclista como os dos motoristas em relaçăo aos ciclistas, e assim reconhece a bicicleta como veículo para o transporte utilitário. 


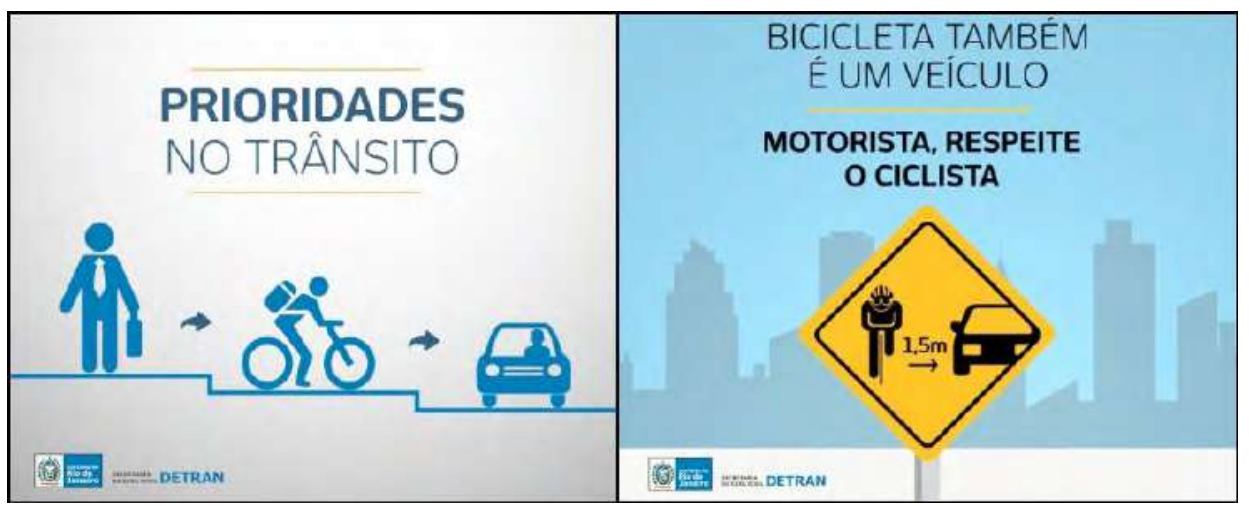

Figura 9 | Reconhecimento da bicicleta como veículo Fonte: Detran

Para motoristas e ciclistas, alguns dos artigos do CTB relacionados aos deveres no contato com ciclistas estâo descritos a seguir:

_. Art. 29 - 0 maior cuida do menor e pedestre é prioridade.

(...) $\S 2^{\circ}$ Respeitadas as normas de circulaçâo e conduta estabelecidas neste artigo, em ordem decrescente, os veículos de maior porte serăo sempre responsáveis pela segurança dos menores, os motorizados pelos năo motorizados e, juntos, pela incolumidade dos pedestres.

\section{Art. 181 - Estacionar onde năo pode é infraçăo.}

(...) VIII - no passeio ou sobre faixa destinada a pedestre, sobre ciclovia ou ciclofaixa, bem como nas ilhas, refúgios, ao lado ou sobre canteiros centrais, divisores de pista de rolamento, marcas de canalizaçăo, gramados ou jardim público.

\section{Art. 193 - Invadir calçadas e ciclovias é gravíssimo.}

Transitar com o veículo em calçadas, passeios, passarelas, ciclovias, ciclofaixas, ilhas, refúgios, ajardinamentos, canteiros 
centrais e divisores de pista de rolamento, acostamentos, marcas de canalizaçăo, gramados e jardins públicos.

\section{Art. 201 - Ultrapassar com menos de 1,50 m.}

Deixar de guardar a distância lateral de um metro e cinquenta centímetros ao passar ou ultrapassar bicicletas.

\section{Art. 214 - Todos devem respeitar o pedestre.}

Deixar de dar preferência de passagem a pedestre e a veículo nâo motorizado:

I - que se encontre na faixa a ele destinada;

II - que năo haja concluído a travessia mesmo que ocorra sinal verde para o veículo;

(...)

IV - quando houver iniciado a travessia mesmo que năo haja sinalizaçâo a ele destinada;

$\mathrm{V}$ - que esteja atravessando a via transversal para onde se dirige o veículo:

\section{_Art. 220 - Ultrapassar sem reduzir a velocidade é proibido.}

Deixar de reduzir a velocidade do veículo de forma compatível com a segurança de trânsito ao ultrapassar ciclista.

Apesar de as regras constarem no CTB, muitos motoristas acreditam que o lugar da bicicleta nâo é no leito carroçável, em compartilhamento do espaço com seu veículo motorizado, por considerar o carro prioritário na pirâmide da mobilidade urbana e pela importância da fluidez do trânsito, e por isso ameaçam a vida de ciclistas diariamente. 
No relatório do Perfil do Ciclista Brasileiro, elaborado pelo projeto Parceria pela Mobilidade por Bicicletas ${ }^{1}$ em 2015, foram entrevistados mais de 5 mil ciclistas de dez cidades brasileiras. Segundo o gráfico 14, 34,6\% dos problemas enfrentados no uso da bicicleta săo referentes à falta de respeito dos condutores dos veículos motorizados. Nova pesquisa realizada em 2018 apontou a falta de segurança no trânsito como o principal problema enfrentado no uso da bicicleta como meio de transporte, conforme o gráfico 15.

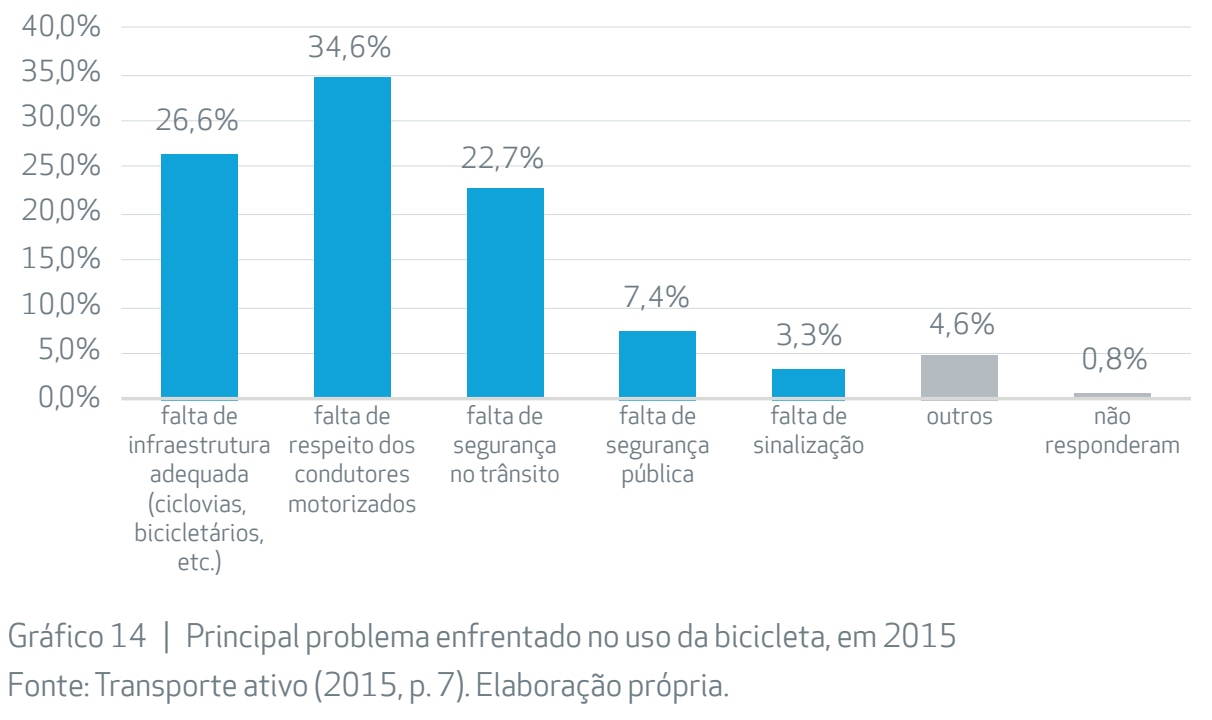

1 Iniciativa do Transporte Ativo, com patrocínio do Banco Itaú, suporte técnico do Laboratório de Mobilidade sustentável do PROURBE-UFRJ e Observatório das Metrópoles e parceria com as organizações locais da sociedade civil. 


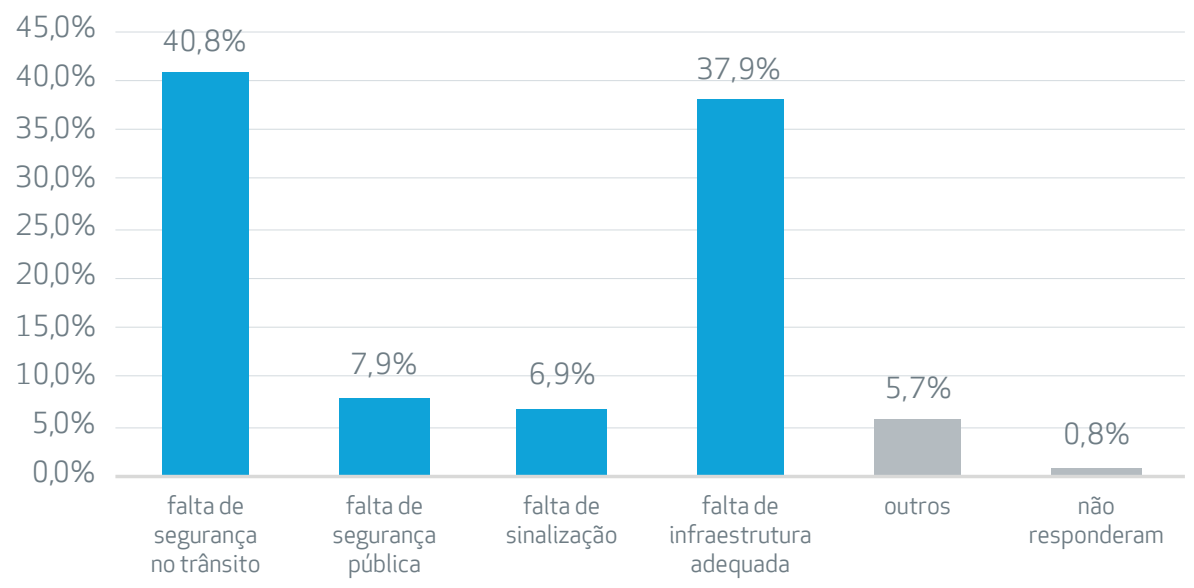

Gráfico 15 | Principal problema enfrentado no uso da bicicleta, em 2018

Fonte: Transporte ativo (2018b, p.4). Elaboração própria.

\subsection{Dados da bicicleta}

Como consequência do desenvolvimento urbano baseado primordialmente no transporte rodoviário, as cidades passaram a sofrer do problema de poluiçâo do ar, o que trouxe malefícios năo apenas aos motoristas, mas a toda a populaçăo. Segundo Esteves et al (2002), 90\% da poluiçâo atmosférica da cidade de Săo Paulo decorre da emissăo de poluentes provenientes de fontes móveis (veículos leves de passageiros, leves de uso comercial e veículos pesados), que provocam doenças respiratórias e cardiovasculares.

A falta de investimento e de políticas públicas voltadas para a bicicleta até o século XXI contribuiu para a baixa porcentagem de viagens feitas com esse modal. A pesquisa Origem e Destino do Município de Săo Paulo de 2007 revela que apenas 0,6\% das viagens diárias eram feitas por bicicleta, conforme o gráfico 16 : 


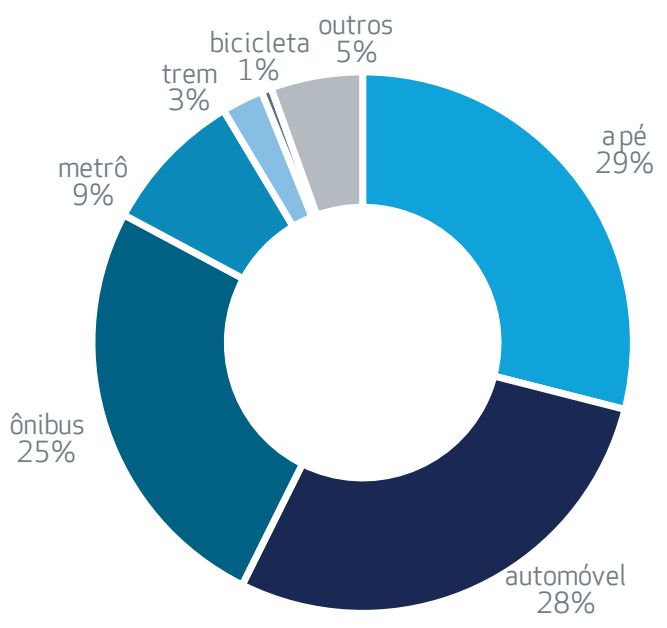

Gráfico 16 | Divisão Modal das viagens realizadas no Município de São Paulo em 2007 Fonte: Pesquisa de Origem e Destino do Metrô - 2007 / Realizada pela CET - GPL/DPJ 2009. (MALATESTA, 2014, p. 48). Elaboração própria.

Os dados apresentados demonstram a baixa participaçăo da bicicleta nos deslocamentos diários na primeira década deste século, além da insignificante integraçăo com outros modais. Houve impressionante salto no uso da bicicleta de quase três vezes entre os anos de 1997 e 2007, após a consolidaçâo desse meio de transporte pelo CTB, porém, proporcionalmente ao número total de viagens do município, a porcentagem continua muito baixa, e passou de 0,3\% para 0,6\% o índice de viagens totais feitas com bicicleta, de acordo com os dados da tabela 6 . 


\begin{tabular}{|c|c|c|}
\hline somente bicicleta & $\mathbf{5 6 . 3 9 8}$ & $\mathbf{1 5 6 . 4 8 2}$ \\
\hline somente bicicleta & 56.398 & 156.482 \\
\hline bicicleta + metrô & - & 2.559 \\
\hline bicicleta + trem & 75 & 772 \\
\hline total bicicleta & 56.473 & 159.813 \\
\hline total de todos os modos & 21.166 .766 & 25.525 .477 \\
\hline
\end{tabular}

Tabela 6 | Registro do acréscimo das viagens realizadas por bicicletas no Município de São Paulo em 1997 e 2007 - modal único e integrado a outros modais

Fonte: Pesquisa de Origem e Destino do Metrô - 2007 / Tabulação elaborada pela CET - GPL/ DPJ 2009. (MALATESTA, 2014, p. 49). Elaboração própria.

Apesar de a bicicleta constar no CTB na condiçăo de veículo de transporte utilitário, nâo apenas de esporte e lazer, é necessário incentivar seu uso e oferecer infraestrutura cicloviária, de forma a proporcionar segurança e conforto aos usuários, tanto para o deslocamento, com a construçâo de ciclovias e ciclofaixas, quanto para fomentar a integraçâo modal nas estaçôes e terminais de transporte público, com a adoçăo de bicicletários.

O uso da bicicleta por gênero em 2009, na cidade de Sâo Paulo, aponta a maioria de público masculino, segundo o gráfico 17. 


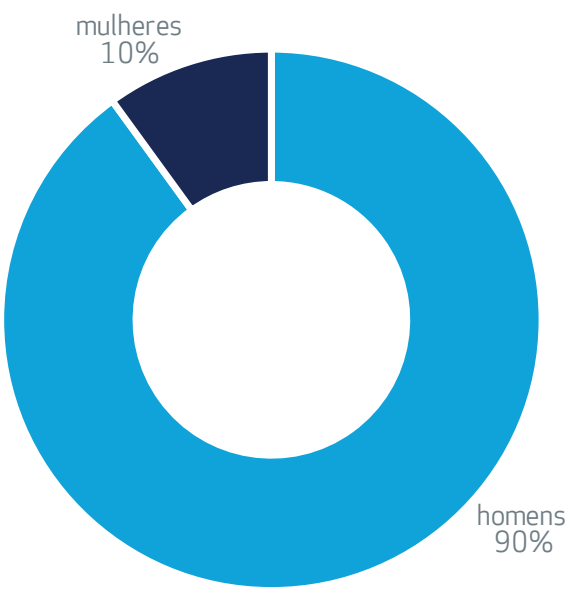

Gráfico 17 | Usuário diário da bicicleta por gênero em 2009

Fonte: Pesquisa de Origem e Destino do Metrô - 2007 / CET / GPL / DPJ - 2009. (MALATESTA, 2014, p. 64). Elaboração própria.

Na Pesquisa do Perfil de quem usa bicicleta na cidade de Săo Paulo, de 2015, houve 1.804 respostas de ciclistas que utilizam esse meio de transporte pelo menos uma vez por semana em regiôes centrais e periféricas da cidade, dos quais apenas 257 sâo mulheres. Ao analisar gênero e tipo de bicicleta, privada ou pública (dos sistemas de compartilhamento BikeSampa e CicloSampa, operantes em 2015 no centro expandido da cidade, totalizando $3 \%$ dos ciclistas na presente pesquisa, segundo o gráfico 18), identifica-se maior proporçấo de mulheres (em relaçăo à homens) nas bicicletas públicas (29\% do total de adeptos de bicicletas públicas) do que das bicicletas privadas, constituindo $14 \%$ do total de usuários desse segmento (gráfico 19). O maior número de mulheres foi observado na regiâo central da cidade, de acordo com o gráfico 20. Percebeu-se também que as bicicletas públicas sâo mais usadas por ciclistas recentes e por aqueles que pedalam entre um e três dias por semana. 


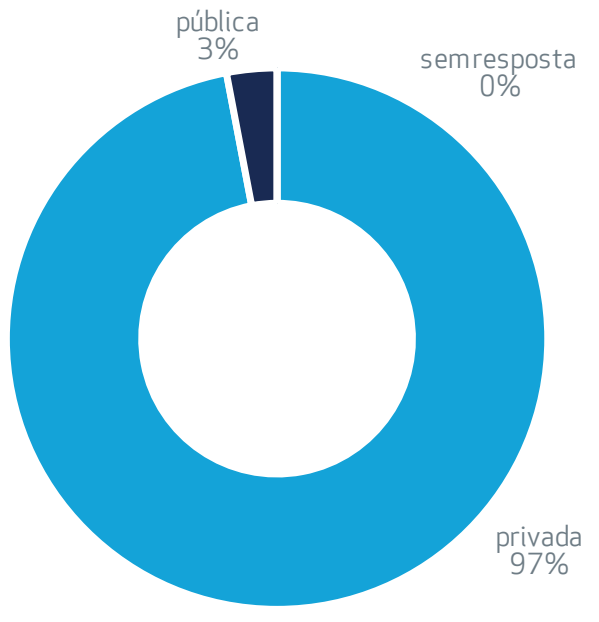

Gráfico 18 | Tipo de bicicleta utilizada: privada ou pública Fonte: Ciclocidade (2015b, p.13)

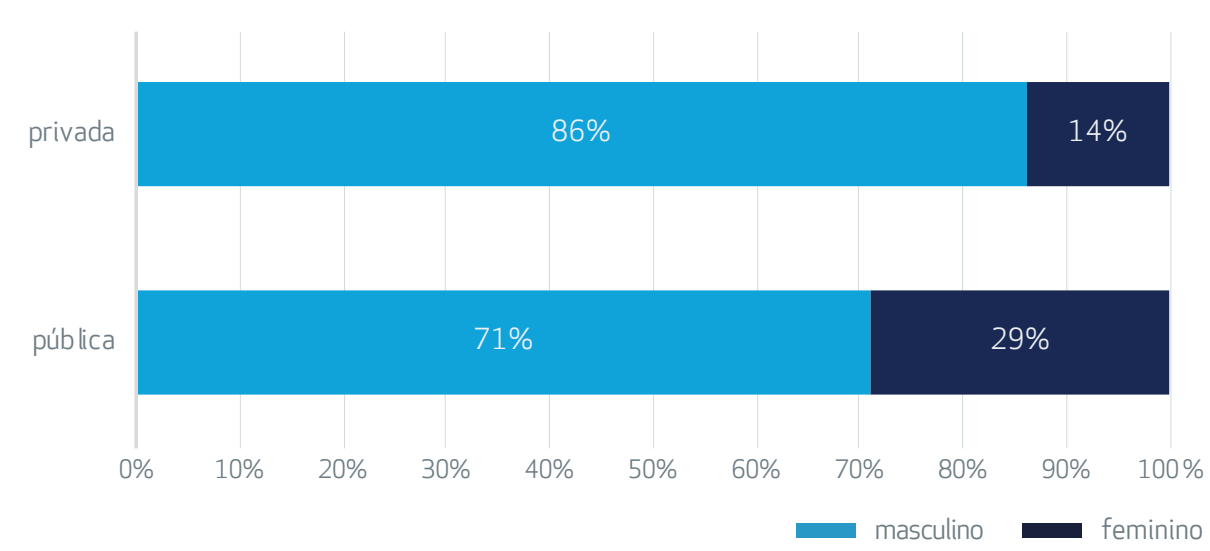

Gráfico 19 | Tipo de bicicleta e a distribuição por gênero Fonte: Ciclocidade (2015b, p.14) 


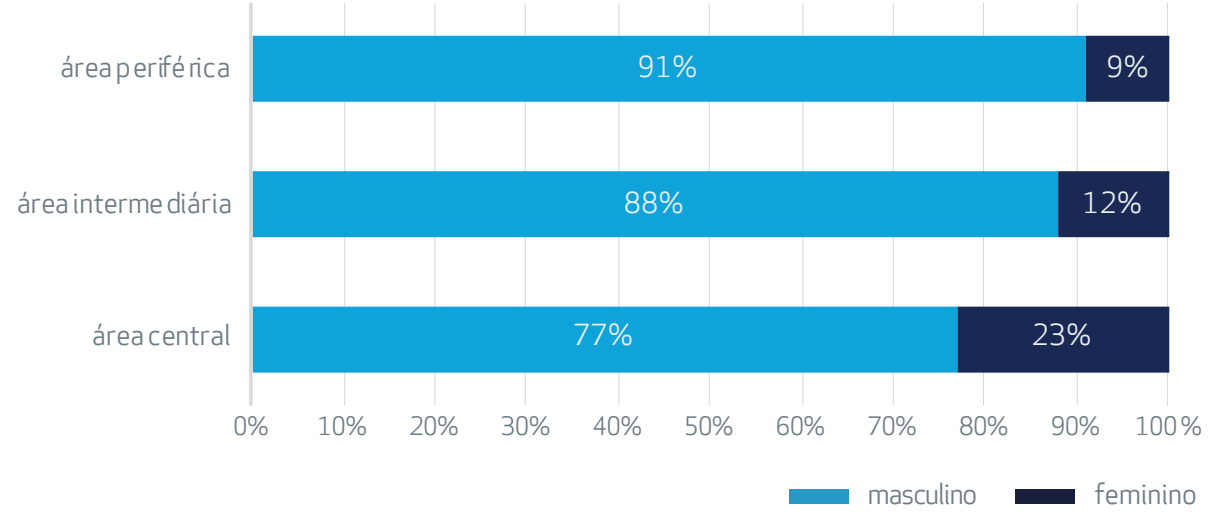

Gráfico 20 | Área da cidade e distribuição por gênero

Fonte: Ciclocidade (2015b, p.16)

Essa disparidade se dá principalmente devido à insegurança no trânsito e à falta de infraestrutura cicloviária. Na regiăo central, onde há mais ciclovias e ciclofaixas recentes, $23 \%$ do uso da bicicleta săo realizados por mulheres, pelo estímulo que a infraestrutura produz, tanto para mulheres quanto para homens, por auxiliar a repensar a maneira de locomoçâo cotidiana, enquanto que na área periférica há apenas $9 \%$. No entanto, a análise feita no relatório revela que é muito simplista limitar a explicaçăo sobre o baixo índice de mulheres ciclistas à falta de infraestrutura.

As barreiras para esse modo de transporte săo maiores quando se trata de mulheres pobres e com menor escolaridade. (...) elas encontram uma série de impedimentos, principalmente sociais, resultados do machismo estrutural e que negam às mulheres certas atividades e lugares (CICLOCIDADE, 2015b, p.16).

O relatório produzido pela Ciclocidade em 2015 referente à contagem de ciclistas no cruzamento da Avenida Brigadeiro Faria Lima com a Avenida 
Rebouças, no centro expandido de Săo Paulo, contabilizou 13,5\% de ciclistas mulheres. Nova contagem realizada pela mesma organizaçăo, em 2018, observou índice de 20\%. Mais adiante, será discutida, também, a diferença encontrada no uso da bicicleta do sistema compartilhado Bike Sampa em 2018, que apresentou aumento da proporçăo de público feminino para $25 \%$.

Segundo Malatesta (2014, p.47), “o processo de apropriaçăo da cidade por bicicleta é realizado por cidadâos pertencentes a dois segmentos distintos da sociedade". O primeiro é aquele que é afetado pela má qualidade do transporte público, que opta pela bicicleta para economia de tempo e custo, e o segundo é constituído por pessoas pertencentes às camadas de elite, com poder para exercer influência na política pública. Exemplos desses ciclistas sâo os cicloativistas que trabalham na mídia escrita, digital e no rádio, como a arquiteta e jornalista Renata Falzoni, responsável atualmente pelo portal na internet Bike é Legal².

Esses tipos de ciclistas podem ser explicados com base na pesquisa do perfil do usuário de bicicleta na cidade de Săo Paulo (2015), em que se identificaram diferenças entre o ciclista da área central e o das áreas periféricas quanto a gênero, renda e escolaridade, principalmente, apresentadas nos gráficos a seguir.

A análise da escolaridade mostra que 57\% dos ciclistas na área central têm ensino superior e pós-graduaçăo, contra apenas 18\% na área periférica (gráfico 21). Na área central da cidade, 22\% dos ciclistas ganham até dois

2 Disponivel em: <https://bikeelegal.com/>. Acesso em: 25 jan. 2019. 
salários-mínimos, enquanto na área intermediária e periférica esse índice ultrapassa 40\% (gráfico 22).

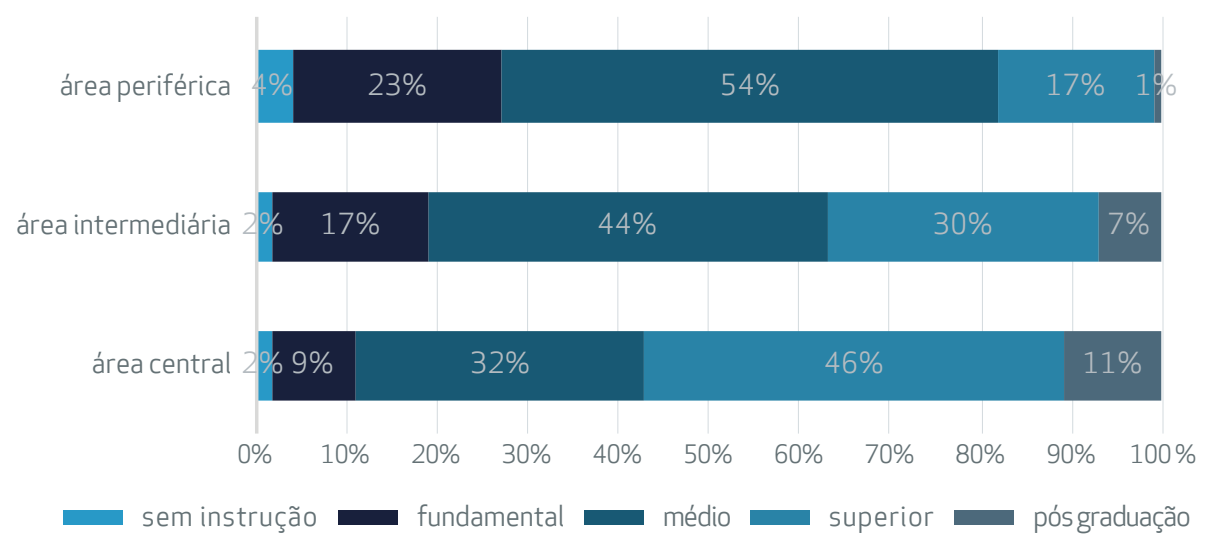

Gráfico 21 | Área da cidade e distribuição por escolaridade (considerado o último segmento completo)

Fonte: Ciclocidade (2015b, p.19).

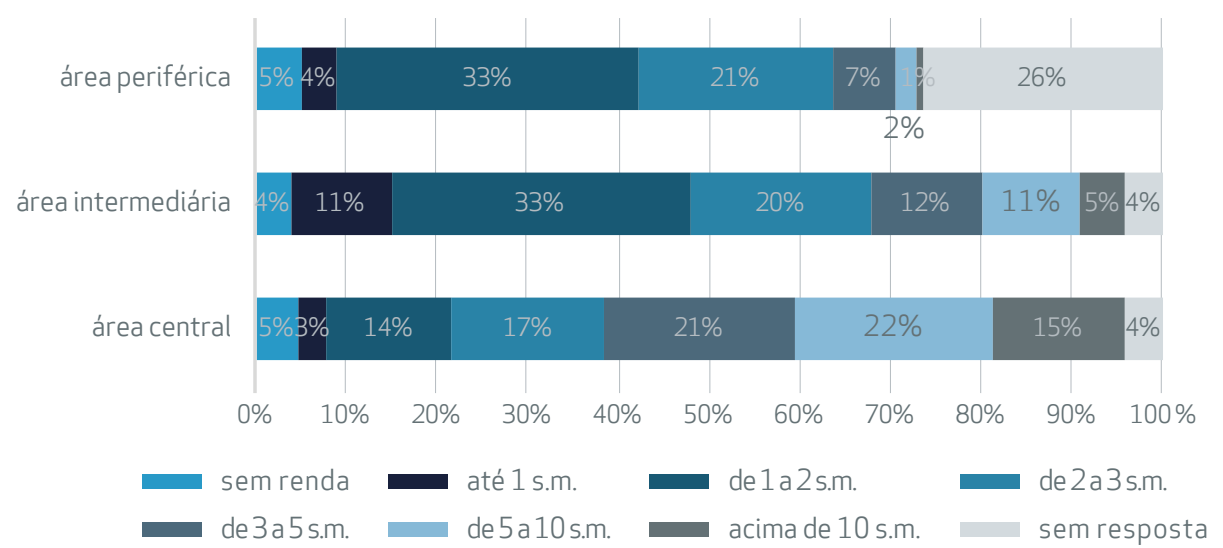

Gráfico 22 | Área da cidade e distribuição por renda (salário mínimo de R\$788,00)

Fonte: Ciclocidade (2015b, p.20). 


\subsubsection{Diretrizes públicas voltadas à bicicleta}

No século XXI, diante dos problemas urbanos de cidades cujo traçado é desenhado prioritariamente para os automóveis, surgiram diretrizes federais de mobilidade urbana que consideram modais alternativos.

O caderno MCidades (2004) sobre mobilidade urbana apresenta a diretriz de desenvolvimento de meios năo motorizados de transporte, com a intençăo de diminuir o custo da mobilidade das pessoas com a adoçăo da bicicleta nos deslocamentos urbanos, superando a visăo predominante da bicicleta como veículo para o lazer. É descrita a importância de sua integraçăo com os modos coletivos de transporte, vinculada à necessidade de adotar novo modelo de desenho urbano, com a inclusăo da infraestrutura cicloviária nos projetos de expansăo urbana.

Entre os dez princípios que devem pautar os planos de mobilidade, destacase a importância dada aos modos năo motorizados de transporte e sua ligaçăo com o transporte coletivo, visando à qualidade de vida e à segurança das pessoas, como prioridade à fluidez do tráfego de veículos, além da necessidade do reconhecimento do deslocamento dos pedestres e da valorizaçăo da bicicleta como meio de transporte importante conectado à rede de transporte coletivo (MINISTÉRIO DAS CIDADES, 2004).

Conforme a Política Nacional da Mobilidade Urbana Sustentável, elaborada pelo Ministério das Cidades em 2004: 
A mobilidade urbana sustentável pode ser definida como o resultado de um conjunto de políticas de transporte e circulaçăo que visa proporcionar o acesso amplo e democrático ao espaço urbano, através da priorizaçâo dos modos náo motorizados e coletivos de transporte, de forma efetiva, que năo gere segregaçôes espaciais, socialmente inclusiva e ecologicamente sustentável. Ou seja: baseado nas pessoas e năo nos veículos (MINISTÉRIO DAS CIDADES, 2004, p.13, grifo nosso).

No Plano de Mobilidade por Bicicleta nas Cidades (2007), o conceito de mobilidade urbana para cidades sustentáveis será reforçado pela adoçâo da bicicleta nos deslocamentos urbanos "como forma de inclusâo social, de reduçáo e eliminaçâo de agentes poluentes e melhoria da saúde da populaçăo", além de contribuir para "novas reflexôes sobre o uso e a ocupaçăo do solo urbano" (MINISTÉRIO DAS CIDADES, 2007a, p.13).

A seguir, săo apresentados alguns dos princípios da nova visăo de mobilidade urbana, em que se denotam o foco na diminuiçấo do uso do veículo particular e a necessidade da mudança de paradigma e redistribuiçăo do espaço entre os modais (MINISTÉRIO DAS CIDADES, 2007a, p.16).

_iminuir a necessidade de viagens motorizadas, devido à aproximaçâo da oferta de emprego e serviços à moradia; repensar o desenho urbano, para priorizar a segurança e a qualidade de vida das pessoas em vez de a fluidez do tráfego de veículos de passagem;

repensar a circulaçăo de veículos, com foco nos meios năo motorizados e no transporte coletivo e náo no transporte individual. "A cidade năo pode ser pensada como, se um dia, todas as pessoas fossem ter um automóvel." 


\footnotetext{
_desenvolver meios năo motorizados de transporte, com a

valorizaçăo da bicicleta como meio de transporte relevante e sua integraçăo com modos de transporte coletivo; _reconhecer a importância do deslocamento de pedestres; _reduzir os impactos ambientais da mobilidade urbana.
}

Acredito que a mudança de paradigma presente nas diretrizes do Plano de Mobilidade seja identificada como necessária, devido à crise da mobilidade urbana que as cidades brasileiras vivenciam no contexto atual: "trata-se de reverter o atual modelo de mobilidade, integrando-a aos instrumentos de gestâo urbanística, subordinando-se aos princípios da sustentabilidade ambiental e voltando-se decisivamente para a inclusăo social" (MINISTÉRIO DAS CIDADES, 2007b, p.21).

Em 2012, foi promulgada a Lei $n^{0}$ 12.587/12 que instituiu a Política Nacional de Mobilidade Urbana (PNMU), com intuito de orientar as açôes dos governos municipais, estaduais e federal em prol da mobilidade urbana sustentável. Para acompanhamento da implantaçăo da política, a Secretaria Nacional de Mobilidade Urbana (Semob) elaborou diagnóstico de efetividade da PNMU. A seguir, seguem alguns dos artigos da Lei ${ }^{0} 12.587 / 12$, com seus princípios, diretrizes e objetivos (grifos nossos).

Art. 5’ A Política Nacional de Mobilidade Urbana está fundamentada nos seguintes princípios:

I - acessibilidade universal;

II - desenvolvimento sustentável das cidades, nas dimensôes socioeconômicas e ambientais;

III - equidade no acesso dos cidadăos ao transporte público coletivo; 
IV - eficiência, eficácia e efetividade na prestaçăo dos serviços de transporte urbano;

V - gestăo democrática e controle social do planejamento e avaliaçăo da Política Nacional de Mobilidade Urbana;

VI - segurança nos deslocamentos das pessoas;

VII - justa distribuiçâo dos benefícios e ônus decorrentes do uso dos diferentes modos e serviços;

VIII - equidade no uso do espaço público de circulaçăo, vias e logradouros; e

IX - eficiência, eficácia e efetividade na circulaçâo urbana.

Art. $6^{\circ}$ A Política Nacional de Mobilidade Urbana é orientada pelas seguintes diretrizes:

I - integraçăo com a política de desenvolvimento urbano e respectivas políticas setoriais de habitaçăo, saneamento básico, planejamento e gestăo do uso do solo no âmbito dos entes federativos;

II - prioridade dos modos de transportes náo motorizados sobre os motorizados e dos serviços de transporte público coletivo sobre o transporte individual motorizado;

III - integraçáo entre os modos e serviços de transporte urbano; IV - mitigaçáo dos custos ambientais, sociais e econômicos dos deslocamentos de pessoas e cargas na cidade;

$\mathrm{V}$ - incentivo ao desenvolvimento científico-tecnológico e ao uso de energias renováveis e menos poluentes;

VI - priorizaçăo de projetos de transporte público coletivo estruturadores do território e indutores do desenvolvimento urbano integrado; e VII - integraçâo entre as cidades gêmeas localizadas na faixa de fronteira com outros países sobre a linha divisória internacional.

Art. $7^{\circ}$ A Política Nacional de Mobilidade Urbana possui os seguintes objetivos: 
I - reduzir as desigualdades e promover a inclusâo social;

II - promover o acesso aos serviços básicos e equipamentos sociais;

III - proporcionar melhoria nas condiçōes urbanas da populaçăo no que se refere à acessibilidade e à mobilidade;

IV - promover o desenvolvimento sustentável com a mitigaçăo dos custos ambientais e socioeconômicos dos deslocamentos de pessoas e cargas nas cidades; e

V - consolidar a gestăo democrática como instrumento e garantia da construçâo contínua do aprimoramento da mobilidade urbana.

Na PNMU, definiu-se o prazo de abril de 2015 para a elaboraçấo dos planos de mobilidade de todos os municípios com mais de 20 mil habitantes, de forma a habilitá-los a receber os repasses do governo federal destinados a obras de infraestrutura. Segundo Silva (2014, p. 42), "nesta nova lei em vigor temos um avanço legislativo, mas năo há diretrizes e modelos para um avanço metodológico de planejamento e de implantaçâo de modelos para ciclistas".

Apesar de o incentivo aos meios năo motorizados de transporte constar como diretriz na PNMU desde 2004, Vasconcellos (2013, p.1) argumenta: “o patrimônio público das vias năo vem sendo distribuído igualmente entre as pessoas; portanto, considerar os investimentos no sistema viário democráticos e equitativos năo passa de um mito." Poucas açôes de fato foram concretizadas, e, quando realizadas, tiveram pouca aceitaçâo inicial por parte da populaçâo.

Como exemplo, cito a Cidade de Sáo Paulo, que passou por momento único na história do desenvolvimento urbano, devido às açôes do poder público municipal, que ocorreram de 2012 a 2016. O Plano de Mobilidade Urbana inverteu a priorizaçâo tradicional e estabeleceu a seguinte ordem: pedestres, ciclistas, transporte público, transporte de carga e finalmente 
automóveis e motocicletas (PREFEITURA DE SÃO PAULO, 2015b), na tentativa de contribuir para a mudança da posiçăo de primazia do automóvel vigente no planejamento da cidade.

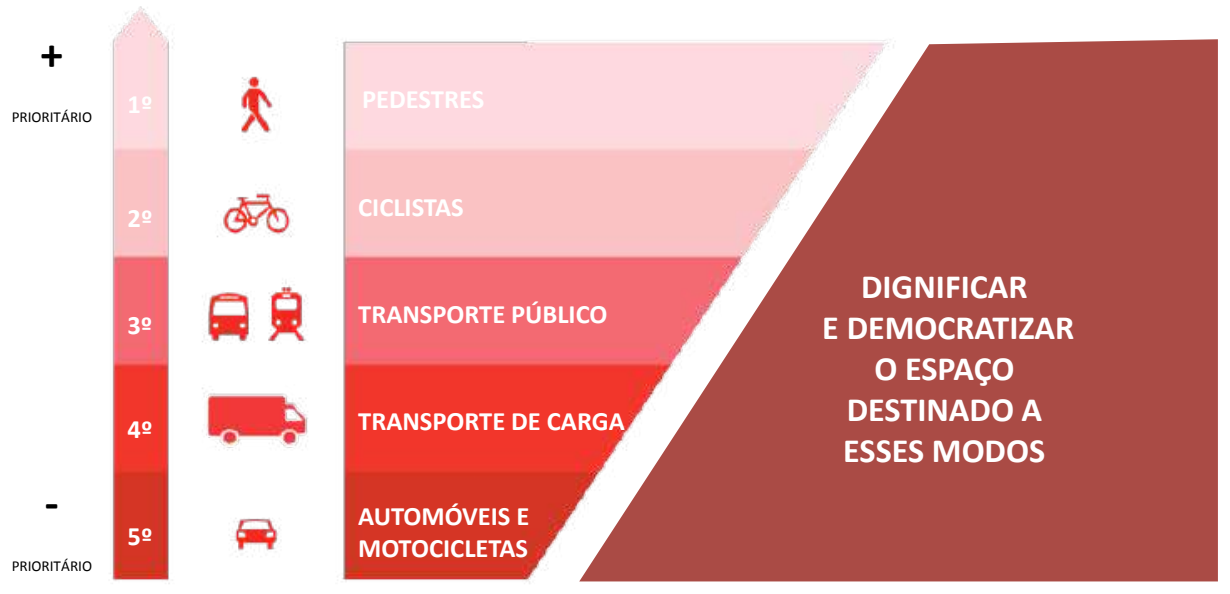

Figura 10 | Plano Municipal de Mobilidade de São Paulo

Fonte: Prefeitura de São Paulo (2015b). Apresentação do Secretário de Transportes Jilmar Tatto, debates temáticos para a construção do PLANMOB, abril de 2015.

Em reportagem publicada no Diário do Transporte em dezembro de 2016, revela-se que Fernando Haddad, prefeito da cidade de Săo Paulo no período de 2012 a 2016, trouxe nova forma de ver a cidade e ampliou o debate sobre o uso do espaço público, com a priorizaçăo de pedestres, faixas de ônibus e ciclovias, de modo a revelar uma nova dinâmica urbana (BAZANI, 2016). Outras açôes, como a reduçăo da velocidade das vias, a abertura de ruas para pedestres e seu fechamento para carros, geraram discussōes e inquietudes na populaçâo e contribuíram para o debate.

Além de seguir as diretrizes da política nacional, o foco no transporte nâo motorizado e coletivo na cidade de Săo Paulo, de 2012 a 2016, equipara-se 
aos movimentos que ocorreram em outras importantes cidades, como Nova Iorque, Bogotá e Copenhague, com mudanças constantes do espaço público e investimentos nos sistemas alternativos de locomoçăo, o que viabilizou a dimensâo humana no planejamento urbano, como acredita Jan Gehl:

(...) a cidade sustentável é geralmente fortalecida se grande parte de seu sistema de transporte puder se dar por meio da "mobilidade verde", ou seja, deslocar-se a pé, de bicicleta ou por transporte público. Outro aspecto sustentável importante é o aumento de atratividade exercida pelos sistemas de transporte público, quando os usuários se sentirem seguros e confortáveis caminhando ou indo de bicicleta para e a partir do ônibus, trens e veículos sobre trilhos (GEHL, 2013, p.7, grifo nosso).

\subsubsection{Leis e decretos sobre infraestrutura cicloviária em São Paulo}

A Lei ${ }^{\circ} 10.907^{3}$, de 18 de dezembro de 1990, regulamentada pelo Decreto n 34.854/1995, dispóe sobre a destinaçâo de espaços para ciclovias no município de Sáo Paulo. A principal determinaçăo dessa lei é a obrigatoriedade de demarcaçăo de espaços para ciclovias na construçăo de novas avenidas. “Entende-se por ciclovias, espaços demarcados no leito carroçável de avenidas, exclusivas para veículos que năo contenham traçăo motora" (Lei n010.907/1990). O Decreto $n^{0} 34.854 / 1995$, assinado pelo prefeito do município de Săo Paulo em 1995, Paulo Maluf, define:

3 Projeto de Lei $n^{\circ}$ 382/89 - Vereador Walter Feldman 
Art. 1: Os futuros estudos, projetos e obras viárias no Município de Săo Paulo, visando a construçâo de avenidas, contemplarâo, obrigatoriamente, espaço destinado à implantaçăo de ciclovias.

(...)

Art. $4^{\circ}$ : Os novos projetos para implantaçăo de avenidas que impliquem construçáo de pontes, viadutos e aberturas de túneis deverăo prever que essas obras de arte sejam dotadas de ciclovias, integradas com o projeto de construçấo da avenida.

(...)

Podemos considerar um avanço a publicaçấo dessa lei, por ter acontecido antes mesmo do CTB, de 1997. No entanto, ela tem sido ignorada em muitos momentos e em outras situaçōes resultou em ciclovias desconectadas e inseguras, como é o caso do prolongamento na Avenida Brigadeiro Faria Lima, na gestăo de Paulo Maluf, em que a ciclovia de curta extensâo terminava no canteiro central sem nenhum acesso para o ciclista (o trecho em questâo foi retirado na gestăo do Gilberto Kassab, em 2012, com o prolongamento da ciclovia em direçâo ao Parque Villa-Lobos), como revelado no artigo de William Cruz (2015). 


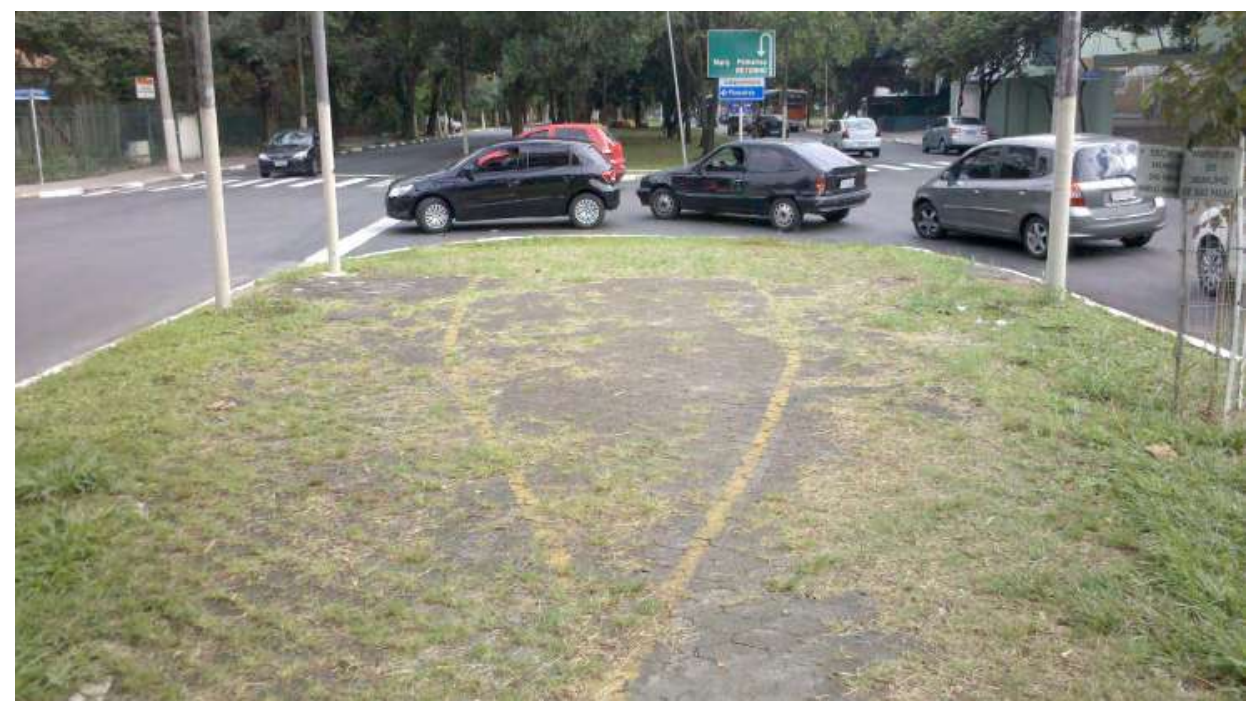

Foto 28 | Ciclovia da Avenida Brigadeiro Faria Lima até 2012. Trecho sem saída da ciclovia no canteiro central, construída com o prolongamento da avenida na gestão do prefeito Paulo Maluf Fonte: William Cruz (2015).

Em 6 de fevereiro de 2007, o prefeito Gilberto Kassab sancionou a Lei $n^{0} 14.266^{4}$ que dispôe sobre a criaçăo do Sistema Cicloviário no município de Săo Paulo

Art. $1^{\circ}$ Fica criado o Sistema Cicloviário do Município de Săo Paulo, como incentivo ao uso de bicicletas para o transporte na cidade de Sấo Paulo, contribuindo para o desenvolvimento da mobilidade sustentável. Parágrafo único. 0 transporte por bicicletas deve ser incentivado em áreas apropriadas e abordado como modo de transporte para as atividades do cotidiano, devendo ser considerado modal efetivo na mobilidade da populaçăo.

4 Projeto de Lei nº 599/05, Vereador Chico Macena. 
No artigo 11, estipula-se que "as novas vias públicas, incluindo pontes, viadutos e túneis, devem prever espaços destinados ao acesso e circulaçáo de bicicletas, em conformidade com os estudos de viabilidade", já previsto desde a Lei $n^{\circ} 10.907 / 90$. No entanto, identificam-se casos de năo cumprimento dessa lei, como é exemplo a Ponte Octávio Frias de Oliveira, na zona sul de Săo Paulo, conhecida como Ponte Estaiada, inaugurada em 2008, que năo contempla calçadas para pedestres, nem espaço para ciclistas.

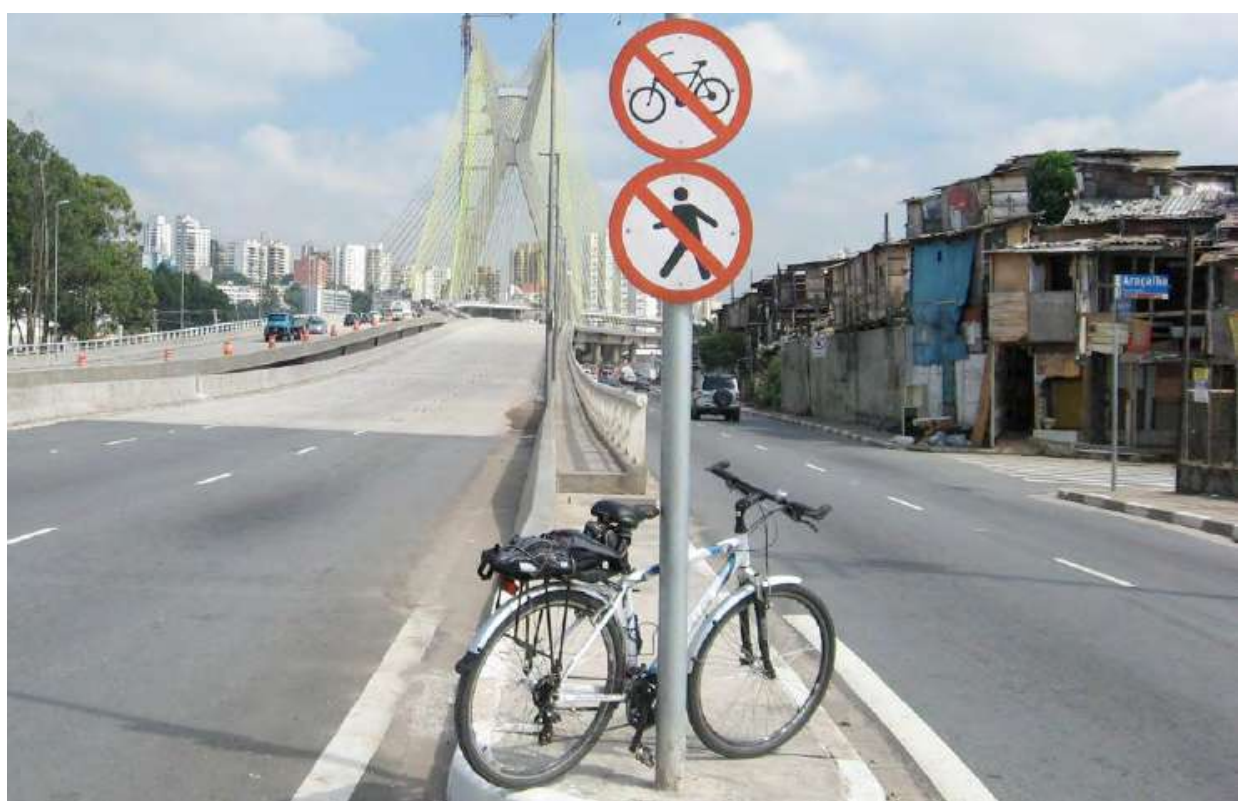

Foto 29 | Ponte Octávio Frias de Oliveira em São Paulo, com proibição de acesso a pedestres e ciclistas

Fonte: Bicicreteiro.org. 
A Lei n $16.738^{5}$, de 7 de novembro de 2017, na gestâo do prefeito Joăo Doria, altera a Lei n 14.266, de 2007, que dispóe sobre o Sistema Cicloviário do Município de Săo Paulo. A principal modificaçăo está descrita a seguir.

Art. $4^{\circ}$ (...). Parágrafo único. A implantaçăo dos trechos cicloviários deverá ser precedida pela realizaçăo de audiências públicas e pela apresentaçăo de estudos de demanda, de viabilidade e de impacto viário, os quais deverăo ser integralmente divulgados em sítio eletrônico próprio.

A justificativa do Projeto de Lei n²23/17 que alterou a lei de 2007, informa que o sistema cicloviário paulistano cresceu de maneira rápida e desordenada na gestâo do prefeito Fernando Haddad, com a construçâo de 400 quilômetros de infraestrutura cicloviária “(...) sem levar em conta a logística de ocupaçấo urbana e as atividades econômicas da cidade. Os vereadores apontam para o fato de que, em vários casos, vias comerciais inteiras foram afetadas por ciclovias ou ciclofaixas sem necessidade, por falta de demanda" (CÂMARA MUNICIPAL DE SĀO PAULO, 2018).

Segundo artigo do site Mobilize Brasil (2018), a nova lei restringirá a construçâo de novas ciclovias e ciclofaixas.

5 Projeto de Lei n 223/17, Vereadores João Jorge - PSDB, Adriana Ramalho - PSDB, Aline Cardoso - PSDB, Aurélio Nomura - PSDB, Claudinho de Souza - PSDB, Eduardo Tuma - PSDB, Fábio Riva - PSDB, Gilson Barreto - PSDB, Mario Covas Neto - PSDB e Quito Formiga - PSDB 
Na prática, porém, segundo os cicloativistas que acompanharam os debates na Câmara Municipal, o objetivo da norma é dificultar a expansăo da rede cicloviária da cidade e apenas implantar ciclovias em trechos que năo retirem espaço dos automóveis, năo atrapalhem o estacionamento em escolas e outros centros de atraçáo.

Há grande receio quanto à obrigatoriedade de apresentaçăo dos estudos de demanda para aprovaçăo da implantaçăo de novos trechos cicloviários, pois as ciclovias têm justamente o efeito indutor de viagens. Segundo estudo do Centro Brasileiro de Análise e Planejamento (CEBRAP), houve aumento de 227\% no fluxo de ciclistas na Rua da Consolaçáo depois da implantaçăo da estrutura cicloviária (CALLIL; CONSTANZO, 2017).

Pela repercussăo negativa da nova lei, a prefeitura divulgou texto, em 9 de novembro de 2017, para esclarecimento.

\footnotetext{
A Lei $n^{\circ} 16.738$, sancionada nesta quarta-feira (8/11/2017), segue a política adotada nesta gestăo, que é defender um amplo debate democrático para o planejamento cicloviário. A açâo vem sendo realizada desde o início do ano, por meio de diálogo com a sociedade, a comunidade de ciclistas, além de comerciantes e representantes das Prefeituras Regionais.
}

A diretriz da gestăo é dar a máxima utilidade às ciclovias existentes, promovendo a interligaçâo da malha cicloviária com terminais de ônibus, do Metrô e da CPTM. As propostas e conclusôes apresentadas direcionarăo o programa de implantaçăo do Sistema Cicloviário do Município. Portanto, o objetivo nâo é dificultar a implementaçăo, mas verificar a viabilidade técnica de cada local (SECRETARIA ESPECIAL DE COMUNICAÇĀO, 2017). 
Apesar da intençăo de fomentar o processo participativo e a realizaçăo de estudos para a implementaçăo das ciclovias, parece prudente a preocupaçăo dos cicloativistas. Afinal, desde 2016 até a presente data năo houve incremento na quilometragem de ciclovias e ciclofaixas. Segundo a CET6, Sâo Paulo possui 468 km de ciclovias e ciclofaixas e 30,3 km de ciclorrotas, totalizando 498,3 km de vias com tratamento cicloviário permanente, a mesma quantidade existente na gestâo do prefeito Fernando Haddad, que terminou o mandato em 2016 (LOBO, 2016).

\subsubsection{Histórico do SPBC no Brasil}

Os sistemas públicos de bicicletas compartilhadas chegaram ao Brasil em 2008, e foram iniciados no formato de compartilhamento de bicicletas, no Rio de Janeiro. Ao longo do tempo, além da modernizaçăo desse primeiro método, outras cidades passaram a adotar fórmulas semelhantes de compartilhamento de bicicletas com estaçâo: Săo Paulo (Bike Sampa, 2012), Porto Alegre (BikePoA, 2012), Salvador (Bike Salvador, 2013), três cidades de Pernambuco - Recife, Olinda e Jaboatăo dos Guararapes - com o sistema estadual (Bike PE, 2013), Belo Horizonte (Bike BH, 2014) e Brasília (Bike Brasília, 2014).

O primeiro sistema inaugurado no Rio de Janeiro chamava-se Pedala Rio, no entanto foi reestruturado a partir de 2011 para o conhecido Bike Rio,

6 Disponivel em: <http://www.cetsp.com.br/consultas/bicicleta/mapa-de-infraestruturacicloviaria.aspx.>. Acesso em: 19 fev. 2019. 
devido a constantes problemas com furtos, usabilidade do sistema e falta de bicicletas (CRUZ, 2011).

Os sistemas foram exitosos durante os primeiros anos, com aumento gradual do número de estaçôes e consequentemente de viagens. No artigo do Mobilize (RIBEIRO, 2016), revela-se a liderança do Bike Rio no ranking do serviço de compartilhamento de bicicletas, com a média de viagens por bicicleta de 6,88 por dia. Segundo o ITDP (2014), o ideal é que cada bicicleta tenha de quatro a oito viagens por dia para garantir a rotatividade, essencial para o sucesso da fórmula.

Com o passar dos anos, porém, pode-se perceber pelas notícias divulgadas certa decadência do sistema, tanto por causa de falta de manutençăo, quanto pelo aumento do vandalismo e da perda de bicicletas, que năo foram repostas. A falta de confiabilidade do sistema prejudicou seu uso, o que contribuiu ainda mais para o crescimento no número de roubos.

Guimarâes (2017) descreve as reclamaçôes dos ciclistas usuários do Bike Rio, que incluem falhas no aplicativo, como o năo reconhecimento de devoluçōes e informaçâo errada do número de bicicletas disponíveis nas estaçôes, sistema inoperante e a falta de bicicletas ou presença de bicicletas com defeitos, o que gera grande insatisfaçâo aos usuários.

Em maio de 2017, a Samba Transportes Sustentáveis ${ }^{7}$ foi comprada pela empresa Tembici, e passou a operar as unidades Bike Rio, Bike Sampa,

7 A empresa Samba Transportes Sustentáveis era controlada pela Serttel, empresa que também opera sistemas públicos de bicicletas compartilhadas em cidades brasileiras. 
BikePoA, Bike PE e Bike Salvador, com o objetivo de reformular o sistema e consolidá-lo como modal ativo cotidiano nas cidades em que atuam. Durante os primeiros meses, houve um esforço para consertar as bicicletas e os encaixes com sistema antifurto, na tentativa de evitar o vandalismo, e para repor bicicletas. No entanto, essas açóes năo foram suficientes, e apesar de um leve aumento no número de viagens no período de junho a outubro de 2017 (gráfico 23), o sistema permanecia com diversos problemas, e os usuários continuavam insatisfeitos.

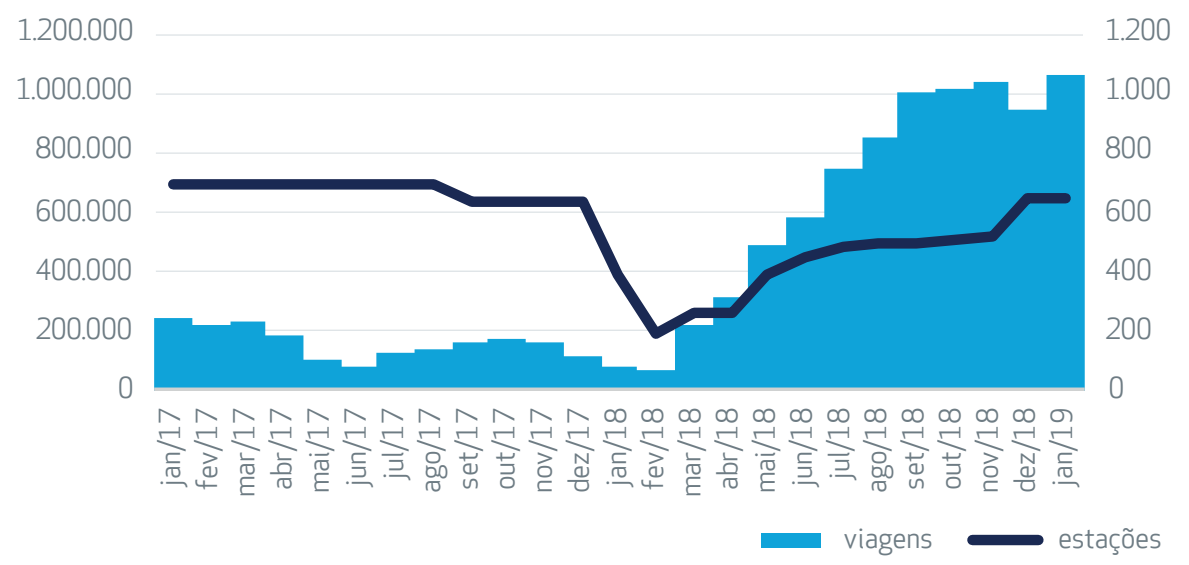

Gráfico 23 | Relação do número de estações e de viagens dos últimos dois anos dos sistemas Bike Rio, Bike Sampa, Bike Salvador, Bike PE e Bike PoA

Fonte: Tembici. Elaboração própria.

Por isso, tomou-se a decisăo de enfrentar os três maiores desafios detectados, em distintas áreas de atuaçăo.

_Tecnologia: sistemas e bicicletas;

_operaçăo: manutençăo e logística;

_projetos: localizaçăo e dimensăo das estaçôes. 


\section{Tecnologia}

A troca da tecnologia por equipamentos de empresa especializada em fornecimento para o segmento de bicicletas compartilhadas com estaçáo foi essencial por contribuir para a confiança e o conforto dos usuários, além de auxiliar na diminuiçáo do vandalismo presente no sistema anterior. A empresa canadense PBSC Urban Solutions foi escolhida, por atestar o funcionamento de sua tecnologia em sistemas de grandes cidades, como Londres, Chicago, Nova Iorque e Guadalajara.

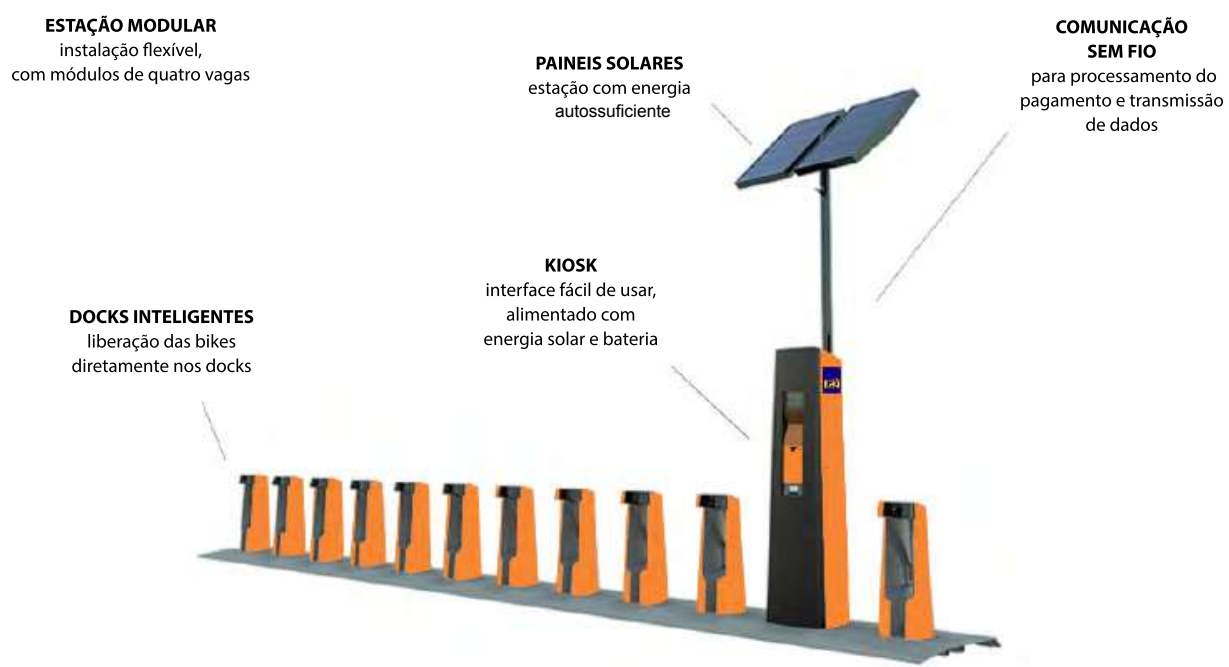

Figura 11 | Estação de bicicletas compartilhadas da PBSC

Fonte: Tembici.

A melhora da operabilidade do sistema e das estaçôes e a facilidade da interface com o usuário, com uso de aplicativo de celular e cartâo do sistema, ou, em alguns casos, integraçáo com o cartâo de transporte da cidade, contribuíram para o aumento do uso e da confiança dos ciclistas. 0 encaixe mais 
robusto dificultou o roubo das bicicletas das estaçôes e a incompatibilidade das peças năo convencionais que compóem as bicicletas também ajudou na diminuiçăo do vandalismo.

A modularidade é aspecto importante, por permitir diferentes tamanhos de estaçăo para locais com demandas distintas. A colocaçăo dos diversos módulos sem a necessidade de obra civil e fixaçăo no piso dá flexibilidade e agilidade ao processo de implantaçăo e troca do sistema. Além disso, permite a instalaçăo em pisos menos regulares, como paralelepípedo e até na grama.

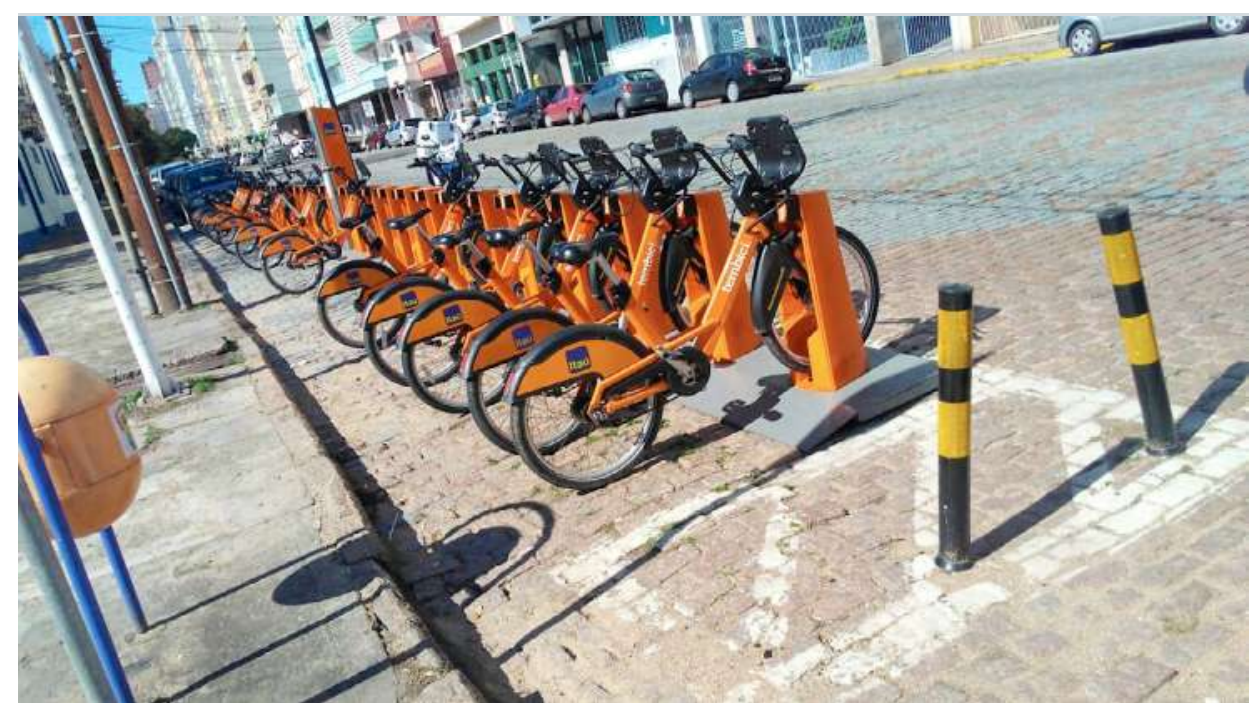

Foto 30 | Bike PoA, estação 7 - Usina do Gasômetro, no paralelepípedo Fonte: Tembici (2018) 


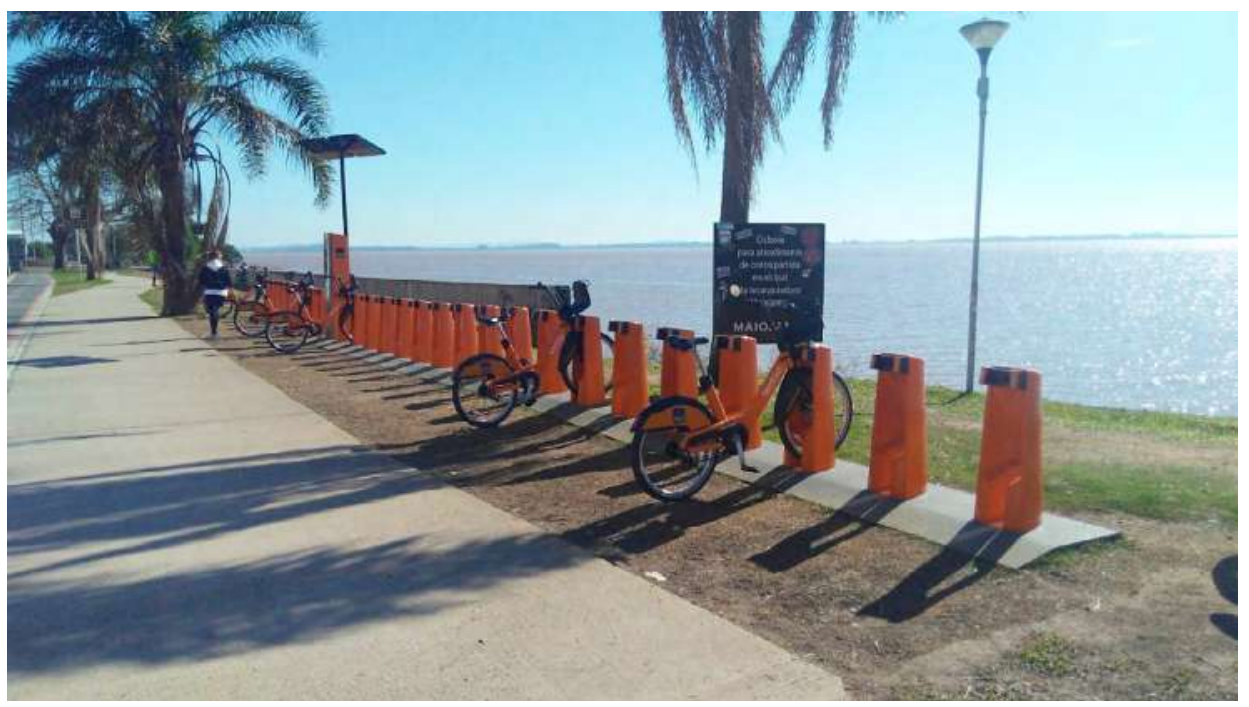

Foto 31 | Bike PoA, estação 41 - Iberê, na grama

Fonte: Tembici (2018)

O principal desafio encontrado no processo de troca de tecnologia consistiu em recuperar a confiança de antigos usuários, que haviam sido prejudicados nos últimos anos pela decadência dos sistemas anteriores. Além disso, o período de transiçăo foi difícil, devido à retirada de todas as estaçōes e a implantaçăo em etapas dos novos equipamentos, o que diminuiu, em certo período, o número de estaçôes e bicicletas em funcionamento. No gráfico 23, identifica-se, no período entre dezembro de 2017 e fevereiro de 2018, a queda drástica do número total de estaçôes e consequente queda do número de viagens, para aumento após a troca do sistema. 


\section{Operação}

A restruturaçâo da operaçâo foi essencial para assegurar a boa qualidade das bicicletas e estaçôes, além de contribuir para a confiabilidade do sistema, ao garantir bicicletas e vagas de acordo com a demanda pendular existente nas cidades. $O$ foco na manutençăo preventiva e năo na corretiva certifica a durabilidade das bicicletas, além da segurança de seu uso. Cada bicicleta passa por revisâo no local a cada sete dias e por revisâo completa no galpăo a cada dois meses. Além disso, as estaçôes săo visitadas pela equipe de conservaçấo no intervalo máximo de três dias, para limpeza e identificaçăo de possíveis problemas enfrentados pelos usuários.

O grande desafio enfrentado desde a troca de tecnologia consiste na redistribuiçăo das bicicletas entre as estaçôes. Essa condiçăo depende da característica de cada cidade e regiâo, e deve ser analisada de maneira singular. Estaçôes em hubs intermodais, como por exemplo a Central do Brasil no Rio de Janeiro e o Largo da Batata em Sâo Paulo, registram demanda tâo grande que as estaçôes de bicicletas compartilhadas existentes năo comportam a quantidade exigida de unidades, o que induziu à necessidade operacional de trabalhar com um bolsăo para estoque de bicicletas e vagas nos horários de pico de transporte da cidade.

Os bolsôes consistem em áreas adjacentes às estaçôes de bicicletas compartilhadas com a presença de funcionários que organizam o estoque inicial para a retirada no período da manhă, quando as pessoas chegam de metrô e utilizam a bicicleta no último quilômetro da viagem e no final do dia, ao retornar ao metrô, momento em que devolvem o veículo. A frota empregada para o reabastecimento das bicicletas năo é suficiente para resolver o problema, justamente porque a demanda é maior no período em que o trânsito está mais carregado, o que torna necessária a formaçăo do bolsâo. 


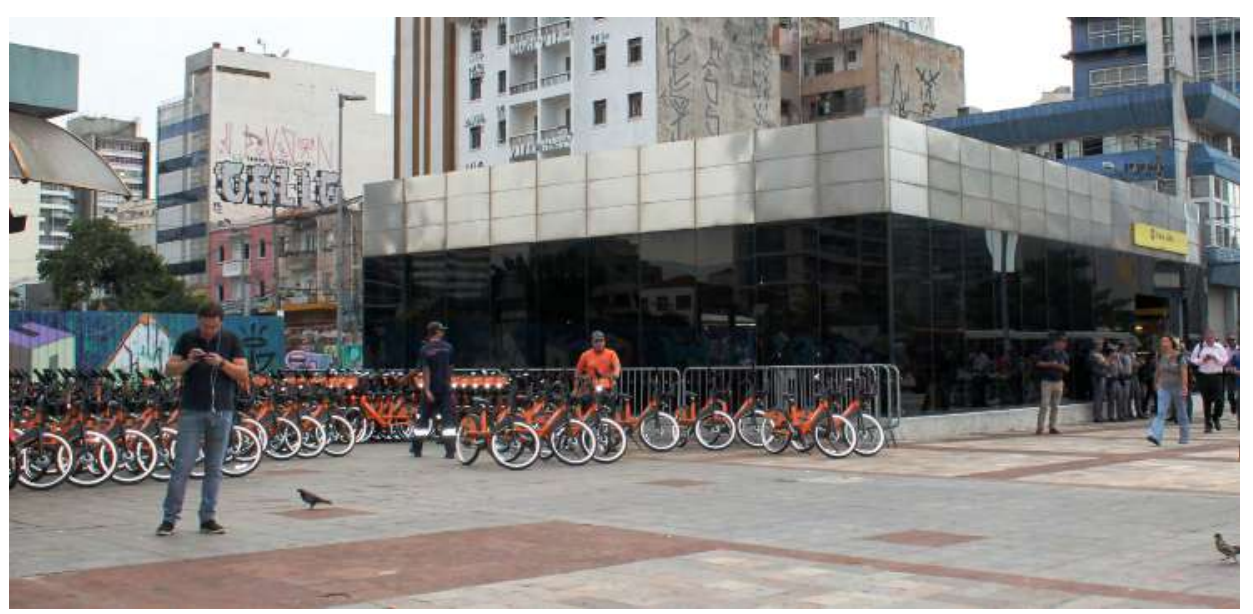

Foto 32 | Bolsão da Estação 1 (Largo da Batata)

Fonte: Luísa Cruz de Melo, em fevereiro de 2019.

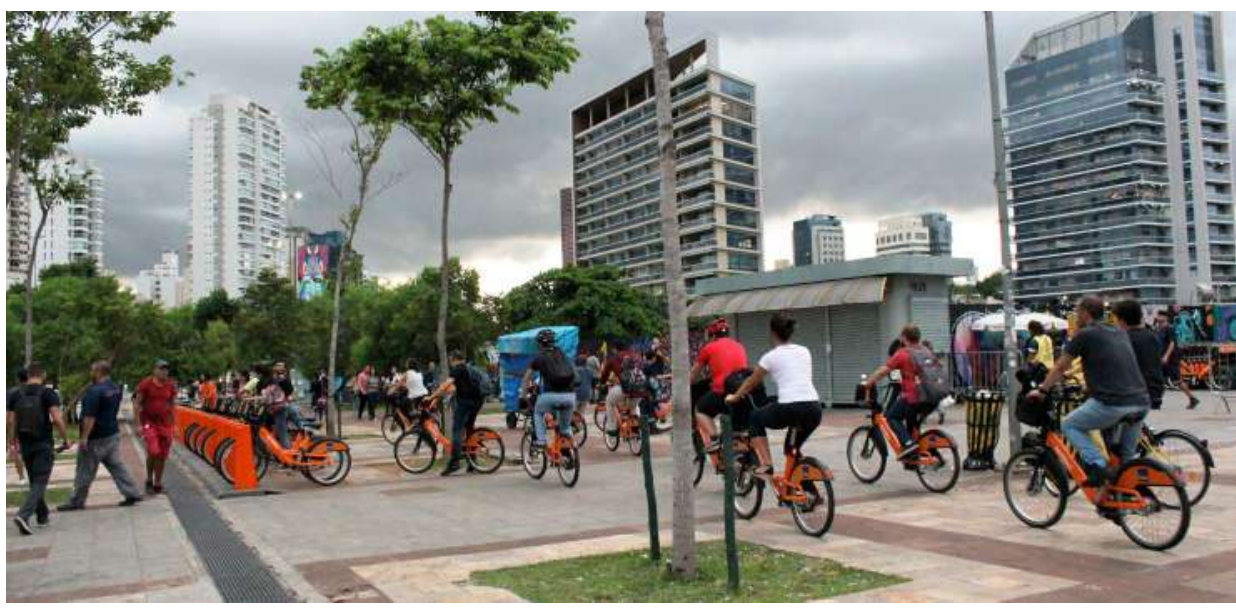

Foto 33 | Estação 1 (Largo da Batata) à esquerda, bolsão à direita (próximo à banca de jornal) e fluxo de ciclistas no final do dia na devolução das bicicletas para integração com o Metrô Fonte: Luísa Cruz de Melo, em fevereiro de 2019. 


\section{Projetos}

A característica mais valorizada de um sistema de bicicletas compartilhadas, de acordo com pesquisa feita com usuários do Citibike (em Nova Iorque), é a conveniência. Esse fator foi mais importante para os usuários do que a prática de exercício físico, a recreaçâo e a economia financeira. A conveniência exige comodidade, facilidade e vantagem, e está relacionada principalmente com a confiabilidade no sistema. E a densidade é a grande responsável por garantir essa confiança. $O$ sistema denso tem maior chance de conectar a residência, o transporte público, o trabalho, o comércio e os serviços e de formar uma malha uniforme em área contínua da cidade.

A distância aproximada de 400 metros entre estaçôes equivale ao percurso de cinco minutos a pé, o que possibilita o fácil acesso entre estaçôes. Se uma estaçăo se encontra vazia em determinado momento, rapidamente o usuário encontra a bicicleta na estaçăo vizinha. O mesmo acontece na hora da devoluçâo, e se uma estaçâo estiver cheia, ele deverá buscar outra estaçâo próxima com vaga disponível. O adensamento proporciona confiabilidade no sistema, pois o próprio usuário tem mais de uma opçâo de estaçăo como local de origem e de destino.

Os sistemas densos permitem a ampliaçăo das alternativas de origem e destino dos usuários do sistema de bicicletas compartilhadas. Os sistemas pouco densos restringem as possibilidades de trajeto e, portanto, năo oferecem real opçâo de transporte.

Ao considerar essas características como condiçōes para o sucesso dos sistemas de compartilhamento de bicicletas, houve também a restruturaçáo 
do planejamento da localizaçâo das estaçôes. As cidades foram analisadas para elaboraçăo de planejamento urbano que considere a integraçăo modal, a infraestrutura cicloviária e os polos geradores de viagens.

Os aspectos principais de mudança foram a criaçăo da rede densa de estaçôes, cuja característica é o espaçamento máximo de 400 e 500 metros entre as estaçôes, e a garantia da sua visibilidade, para que o próprio equipamento sirva como convite ao uso e à inclusăo da bicicleta como alternativa nos deslocamentos diários.

O percurso que uma pessoa está disposta a fazer até encontrar a bicicleta deve ser menor do que a distância que ela caminha para chegar a pontos de ônibus e estaçôes de metrô e trem. Se for maior, facilmente a bicicleta é trocada por outra opçáo de transporte.

O grande desafio, além de convencer o poder público da importância da densidade, que tem como consequência a diminuiçâo da área de cobertura do sistema, é o processo burocrático e complexo presente em algumas cidades, que criam barreira à implementaçâo dos sistemas. Por isso, até novembro de 2018, conforme o gráfico 23, o número total de estaçōes (ao considerar os cinco sistemas brasileiros que passaram pela troca de tecnologia ${ }^{8}$ ) ainda năo tinha sido restaurado - apenas $75 \%$ delas estavam em funcionamento.

8 Bike Sampa (260 estações), Bike Rio (260 estações), Bike PE (80 estações), Bike Salvador (50 estações), Bike PoA (41 estações). Total 691 estações. 


\subsubsection{Participação do poder público}

O ITDP (2014, p.28) revela que "a implementaçáo bem-sucedida de um sistema de bicicletas compartilhadas exige um forte apoio político para garantir a disponibilidade de fundos, direitos de uso do solo e coordenaçăo entre os vários órgáos municipais". Pela minha experiência na implantaçăo dos sistemas públicos de bicicletas compartilhadas nas cidades brasileiras, na maioria dos casos há pouco apoio político e técnico e ficou evidente o interesse restrito por parte do governo no uso da bicicleta como opçáo de transporte. Isso dificulta o planejamento das estaçôes de bicicletas compartilhadas integradas aos sistemas de transporte público da cidade. Há situaçôes em que o contrato do sistema náo é feito com a Secretaria de Mobilidade, o que dificulta o diálogo próximo com os responsáveis para auxiliar a integraçáo modal e o uso da bicicleta como transporte.

_BikePE - Recife, Olinda e Jaboatão dos Guararapes - Operadora Tembici, patrocinador Itaú

Único sistema cujo contrato se encontra no âmbito estadual, na Secretaria de Turismo e Lazer (SETUREL), está presente, portanto, em três cidades vizinhas no Estado de Pernambuco. Foi o primeiro projeto a iniciar a troca de tecnologia, em setembro de 2017, e encontra-se integralmente implantado desde abril de 2018 . 0 processo de autorizaçăo foi simples, com participaçăo da Secretaria de Mobilidade e Controle Urbano (SEMOC), da Secretaria Executiva de Licenciamento e Urbanismo (SELURB) e da Autarquia de Trânsito e Transporte Urbano do Recife (CTTU), todas municipais. 
_BikePoA - Porto Alegre - Operadora Tembici, patrocinador Itaú

O contrato do sistema encontra-se na Empresa Pública de Transporte e Circulaçăo de Porto Alegre (EPTC), da Prefeitura Municipal de Porto Alegre, e o processo de autorizaçấo das estaçôes foi simples e efetivo, centralizado nessa empresa. 0 projeto está com as 41 estaçóes instaladas com a nova tecnologia desde abril de 2018.

Ainda há muita resistência por parte de políticos e da sociedade civil, que se opóem à perda do espaço viário para a bicicleta. Dessa forma, segundo o técnico da EPTC, Antonio Vigna, em depoimento durante a Oficina sobre Sistemas de Bicicletas Públicas, em outubro de 2018, no Rio de Janeiro, o sistema de bicicletas compartilhadas BikePoA desempenha papel fundamental por consolidar a importância dessa opçâo e comprovar os números crescentes de uso da bicicleta na cidade, o que evitou a retirada de ciclovias.

_Bike Salvador - Operadora Tembici, patrocinador Itaú Na etapa da troca da tecnologia realizada em 2018, houve reuniôes da Empresa Salvador Turismo (SALTUR), responsável pelo contrato, com departamentos de trânsito, urbanismo e entidades da sociedade civil, em processo efetivo e rápido para a autorizaçăo do uso do espaço público.

Apesar da maior facilidade na obtençăo da licença para as estaçôes, năo houve a negociaçăo com a Superintendência de Trânsito do Salvador (TRANSALVADOR). Assim, nenhuma estaçâo se encontra em vaga de estacionamento, pois a SALTUR optou por năo realizar o debate sobre a importância da bicicleta para a mobilidade e năo permitiu nenhuma estaçăo fora de calçadas e praças 
_Bike Rio - Rio de Janeiro - Operadora Tembici, patrocinador Itaú O primeiro sistema começou em 2008 e desde entấo funciona como concessăo de publicidade com mobiliário urbano. Segundo relatório do Transporte Ativo (2018a), o contrato trata apenas da quantidade de estaçôes e bicicletas, tendo como gestora a Secretaria Municipal de Fazenda, da Prefeitura Municipal do Rio de Janeiro, que fiscaliza a questăo do mobiliário e náo a da mobilidade. A Secretaria Municipal de Urbanismo (SMU) participa do processo de autorizaçăo das estaçôes de bicicletas compartilhadas do Bike Rio, com a preocupaçấo de reduzir o impacto para o pedestre, o que gera divergência com a Companhia de Engenharia de Tráfego do Rio de Janeiro (CET-Rio), pois como năo há consenso sobre o tratamento do sistema de bicicleta pública, cada área da cidade apresenta uma receptividade diferente. Uma das áreas da CET-Rio, por exemplo, năo aprovou nenhuma estaçăo no leito carroçável (em locais de estacionamento de veículos) por considerar as estaçôes de bicicleta mobiliário urbano e determinou que, por isso, ela seja instalada sempre nas calçadas.

Outra questăo de difícil consenso săo as estaçôes próximas às áreas de patrimônio cultural devido ao impacto visual que elas causam. Pelo histórico da relaçâo das estaçôes com a publicidade, o papel da mobilidade às vezes năo é levado em consideraçáo. Atender a todos os requisitos, muitas vezes subjetivos, de diferentes órgăos da cidade que năo se conversam é atividade quase impossível.

Cada estaçăo dispóe de um processo administrativo distinto que deve ser aprovado por todas as secretarias envolvidas: Secretaria Municipal da Fazenda, Secretaria Municipal de Urbanismo; Fundaçăo Parques e Jardins; CET-Rio; Instituto Rio Patrimônio da Humanidade (IRPH) e, finalmente, a 
Secretaria Municipal de Conservaçăo e Serviços Públicos, responsável pela emissâo da licença após ter o parecer favorável de todos os órgăos.

Passar pelo processo burocrático e longo, que pode durar de 45 a 180 dias, e receber a licença do uso do espaço público năo é garantia para o funcionamento da estaçâo de bicicletas compartilhadas. A reclamaçâo de alguns moradores pela inutilizaçăo de vagas de estacionamento, sem apresentaçăo de argumentos técnicos, é suficiente para a solicitaçăo, por parte da Secretaria Municipal da Fazenda, de remoçâo imediata da estaçăo e a consequente inutilizaçăo da licença emitida, o que leva à perda de tempo, recurso e locais importantes para o funcionamento do sistema. A priorizaçăo do uso do espaço público para o automóvel demonstra o descaso de setores do poder público com o tema da mobilidade ativa.

_Bike Sampa - São Paulo - Operadora Tembici, patrocinador Itaú / Operadora Yellow

A nova regulaçăo permite o credenciamento de diversas empresas que operam sistemas distintos de bicicleta compartilhada com e sem estaçăo (dockless). Segundo a CET, atualmente há mais de uma empresa com a solicitaçăo de aproximadamente 400 pontos para estaçôes de bicicletas na cidade de Sâo Paulo. A situaçâo de Sâo Paulo será explicada com mais detalhe em seguida. Por falta de interesse político, o processo de autorizaçâo das estaçôes é muito lento e retarda a instalaçăo de novas estaçôes no sistema. 
Bike VV - Vila Velha - Operadora Tembici, patrocinadores Samp e Banestes A licitaçâo para a implantaçăo do sistema público de bicicletas compartilhadas na cidade de Vila Velha, no Espírito Santo, ocorreu no fim de 2017, e a empresa vencedora foi a Tembici. O sistema foi pensado para vinte estaçóes e 200 bicicletas, e o poder público tinha dúvida se seria aceito pela populaçăo, por ser uma novidade na cidade. Apesar de ser um sistema pequeno, registra dez viagens por dia de bicicleta (VDB), índice muito elevado (a média em outros países vai de quatro a oito). O grande desafio da cidade é vencer a burocracia do contrato para dobrar o número de estaçôes.

_Bicicletar e Bicicleta Integrada - Fortaleza - Operadora Serttel, patrocinador Unimed Fortaleza

A representante do poder público de Fortaleza na Oficina sobre Sistemas de Bicicletas Públicas, em outubro de 2018, no Rio de Janeiro, Bianca Macedo, explicou que existe vontade política de trabalhar com o modal bicicleta, considerada um meio de transporte prioritário. O estudo da localizaçáo das estaçôes de bicicletas compartilhadas é feito pela mesma equipe que planeja as ciclovias e demais infraestruturas cicloviárias da cidade, para garantir eficiência e lógica no planejamento urbano. Essa equipe atua no Plano de Açôes Imediatas de Transporte e Trânsito (PAITT), ligado à Secretaria de Conservaçâo e Serviços Públicos de Fortaleza.

O Bicicletar é o sistema de compartilhamento de bicicletas públicas disposto em oitenta estaçôes, com patrocínio da Unimed Fortaleza. Ele contabiliza em média seis viagens/dia/bicicleta. O Bicicleta Integrada, inaugurado em 2016, é composto de estaçôes localizadas em terminais de ônibus periféricos da cidade e atua com empréstimo por catorze horas, o que possibilita o trajeto 
do terminal até a casa do usuário e a devoluçăo no dia seguinte. Cada estaçăo é patrocinada por empresas distintas, como supermercados e shopping centers, entre outros. Além desses dois sistemas, há o Mini Bicicletar, de aluguel de bicicletas para crianças, e o Bicicletar Corporativo, exclusivo para funcionários da prefeitura. Bianca Macedo, em reportagem de Soares (2018), revela:

Nâo precisa ter muito dinheiro para fazer política ciclável. Aproveitamos os contratos existentes. $O$ que é necessário é decisāo política e apoio de gestăo. E é por isso que Fortaleza é a cidade que mais avança na mobilidade sustentável no Brasil atualmente. Nossa meta é atuar em três frentes: açôes de alto impacto, de curto prazo e baixo custo.

\subsection{Bike Sampa}

O Bike Sampa é o sistema público de bicicletas compartilhadas na cidade de Săo Paulo. “As bicicletas do Bike Sampa estăo disponíveis em estaçôes distribuídas em pontos estratégicos da cidade, caracterizando-se como uma soluçăo de meio de transporte de pequeno percurso para facilitar o deslocamento das pessoas nos centros urbanos."

Esse sistema possibilita a integraçấo com outros modais e permite que as pessoas cheguem mais próximo de seu destino de maneira rápida e eficiente, por viabilizar a substituiçâo das caminhadas longas ou a perda de tempo excessivo em congestionamentos nos automóveis e ônibus.

9 Disponivel em: <https://bikesampa.tembici.com.br/>. Acesso em 15 dez. 2018. 
Inaugurado em maio de 2012 com aproximadamente dez estaçóes e cinquenta bicicletas, foi ampliado ao longo dos anos e em junho de 2015, data da realizaçăo do estudo do ITDP (2016), contava com 259 estaçōes. 0 projeto Bike Sampa foi realizado pelo Termo de Cooperaçăo para "implantaçăo e manutençăo de sistema de bicicletas compartilhadas" (ITDP, 2016) firmado entre a Secretaria Municipal de Transportes do Município de Sáo Paulo, a empresa operadora e o patrocinador (Itaú), com duraçăo de três anos e previsăo de instalaçăo de 300 estaçôes com doze vagas cada e três mil bicicletas. No entanto, o termo năo foi cumprido, e algumas contrapartidas foram feitas, como a doaçâo de dois mil paraciclos na cidade de Săo Paulo, 300 bicicletas para adultos e crianças e cartilhas educativas sobre mobilidade (DIÓGENES; MENGUE, 2017).

A Lei $n^{0}$ 16.050/14, do Plano Diretor Estratégico de 2014, considera o sistema de compartilhamento de bicicletas como componente do sistema cicloviário ${ }^{10}$ e o incorpora ao planejamento de mobilidade urbana da cidade. O Plano de Mobilidade de Sáo Paulo, de 2015, na gestāo do prefeito Fernando Haddad, define diretrizes para o funcionamento do sistema de compartilhamento e metas relativas à abrangência do território:

\footnotetext{
_implementar um sistema de bicicletas compartilhadas que atenda todas as regiôes da cidade, considerando o uso atual da bicicleta e também o potencial de uso do sistema, em especial para viagens dentro de uma determinada regiâo e de integraçấo com o transporte coletivo;
}

10 Lei nº 16.050/14. Art. 249. São componentes do Sistema Cicloviário:

I- ciclovias; II - ciclofaixas; III - ciclorrotas; IV - bicicletários e demais equipamentos urbanos de suporte; V - sinalização cicloviária; VI - sistema de compartilhamento de bicicletas. 
_integrar o sistema de bicicletas compartilhadas ao sistema de transporte público coletivo de passageiros, implantando sempre que possível estaçôes de bicicletas nas áreas internas dos terminais de ônibus, estaçóes de metrô e trens;

_integrar o sistema de bicicletas compartilhadas ao Bilhete Único; _integrar as estaçôes de bicicletas compartilhadas à Rede Cicloviária Estrutural, privilegiando os locais próximos a esta infraestrutura; implementar um sistema com padrăo único para o travamento das bicicletas às estaçôes, permitindo que uma bicicleta retirada em uma estaçăo possa ser devolvida em qualquer outra;

_coletar, acompanhar e utilizar as estatísticas de uso do sistema de bicicletas compartilhadas para o planejamento cicloviário; manter uma operaçăo equilibrada, oferecendo bicicletas e vagas disponíveis em todas as estaçôes durante seu período de funcionamento; _implantar as estaçôes segundo padrôes e estudos que considerem a densidade adequada ao serviço (PREFEITURA DO MUNICÍPIO DE SÃO PAULO, 2015, p. 110-111).

Em maio de 2015, período do encerramento da vigência do Termo de Cooperaçăo de 2012, a Secretaria Municipal de Mobilidade e Transportes (SMT) publicou a abertura do Chamamento Público nº 001/2015 (processo administrativo 2015-0.121.905-3), realizado com o apoio de ciclistas, com importantes alteraçôes nas regras visando ao aprimoramento dos sistemas, para a:

celebraçăo de Termo de Cooperaçăo, visando a implantaçăo, operaçăo e manutençăo de Sistema Público de Bicicletas Compartilhadas na Cidade de Săo Paulo, através de estaçôes de autoatendimento, ofertando alternativa de transporte sustentável à populaçăo, em consonância com o planejamento cicloviário do Município, de acordo com as especificaçôes e demais disposiçôes constantes do Edital e seus Anexos (SÂO PAULO, maio, 2015). 
Segundo artigo do blog AG Jornalismo ${ }^{11}$, o instrumento legal que regula a contrataçăo sem licitaçăo, através do edital de chamamento público, era o Termo de Cooperaçăo previsto no Decreto Municipal n 52.062/2010, que regula a exploraçăo de publicidade em espaço público:

Esse decreto estabelece, genericamente, a maneira como empresas privadas poderâo explorar a publicidade em espaços e bens públicos ao realizar "obras, serviços, açôes e intervençôes" que promovam "melhorias urbanas, ambientais e paisagísticas", além de conservaçăo de áreas municipais (DURAN, 2016).

De acordo com a advogada consultada pelo AG Jornalismo, esse instrumento é inadequado e insuficiente para a complexidade do serviço de compartilhamento de bicicletas da cidade, por tratar apenas de publicidade, sem considerar requisitos de níveis de serviço da operaçăo do sistema de transporte público.

Em junho de 2015, a prefeitura do município de Săo Paulo comunicou, por meio da SMT, a suspensáo do Chamamento Público Nº 001/2015², revogado em dezembro do mesmo ano (SÂO PAULO, Revogaçâo do Chamamento Público n01/2015).

11 AG Jornalismo é um blog que nasceu como parte do projeto Arquitetura da Gentrificação $(A G)$, criado pela jornalista Sabrina Duran. Caracteriza-se como canal para publicação de investigações e tensionamento a respeito da transparência na administração pública.

12 O chamamento foi suspenso pelo Tribunal de Contas do Município (TCM) sob a alegação de falta de tempo para análise dos argumentos de uma representação enviada por uma das empresas com a solicitação de impugnação. 
A Prefeitura de Sáo Paulo publicou, em janeiro de 2016, um comunicado de manifestaçăo de interesse das empresas Itaú e Samba na celebraçăo do Termo de Cooperaçăo para a instalaçăo e manutençăo de 260 estaçóes de bicicletas de uso compartilhado, totalizando 2.600 bicicletas, pelo período de até três anos ${ }^{13}$.

Em fevereiro de 2016, publicou-se a Lei n016.388, que institui o Programa Integra-Bike Sáo Paulo destinado "à implantaçâo e integraçâo de um sistema de bicicletas públicas aos principais terminais rodoviários, estaçōes de trem e de metrô, no âmbito do Município de São Paulo".

\subsubsection{Regulamentação de SPBC em São Paulo}

Em 22 de setembro de 2017 foi assinado o decreto $n^{\circ} \mathbf{5 7 . 8 8 9 / 1 7}$ que dispóe sobre o compartilhamento de bicicletas em vias e logradouros públicos do município de Sáo Paulo e define novas diretrizes, como a importância de integraçấo com as demais redes de transporte, à rede cicloviária principal, e com o Bilhete Único. Diversas empresas podem se credenciar e operar sistemas de bicicletas compartilhadas com ou sem estaçôes.

Em 28 de julho de 2017, foi realizada uma audiência pública sobre a concessâo do sistema de bicicletas compartilhadas de Sâo Paulo, com a participaçăo da Ciclocidade, que acompanhou o processo e apresentou documento com suas contribuiçôes para o aprimoramento dos sistemas.

13 SÃO PAULO (Cidade). Comunicado para Manifestação de Interesse. Diário Oficial [da] Cidade de São Paulo, São Paulo, SP, 16 jan. 2016. 
O vereador Police Neto foi um dos principais idealizadores desse projeto, que contempla maior transparência de informaçóes, com o requerimento do envio de dados sobre os trajetos dos usuários, e exige opçóes para o uso do sistema para pessoas sem cadastro bancário, ou seja, a venda de planos sem a necessidade de cartâo de crédito, e a integraçâo ao sistema público de transporte (SETO, 2017).

Considero um avanço em relaçăo ao Termo de Cooperaçăo vigente anteriormente, pois, como comentado, esse se baseava no decreto que regula a exploraçáo de publicidade em espaço público. A Ciclocidade (2018b), no entanto, entende que regulamentar o SPBC com uma Operadora de Tecnologia de Transporte Credenciada (OTTC), o mesmo modelo utilizado para serviços particulares de carona compartilhada, revela que o poder público compreende esse serviço como privado e náo como uma política pública de mobilidade. A instituiçâo preocupa-se também com a falta de indicadores de níveis de serviço e referências à área de cobertura, adensamento, formas de pagamento e transparência no compartilhamento de dados, e com o fato de a negociaçăo das exigências das empresas poder ser realizada diretamente com o Comitê Municipal do Uso do Viário (CMUV), sem participaçăo da sociedade civil.

Em 12 de dezembro de 2017, o credenciamento das OTTC foi regulamentado com a Resoluçâo n017. Definiu-se a documentaçăo a ser entregue pelas empresas interessadas, a apresentaçăo do Plano de Implantaçăo do Serviço de Compartilhamento de Bicicletas, assim como a determinaçăo do preço público pela área ocupada para sua instalaçăo. 
Em julho de 2018, a CET divulgou os critérios de sinalizaçăo para as estaçōes de bicicletas compartilhadas com e sem estaçăo, dez meses após a publicaçấo do decreto que oficializava as novas determinaçóes para o compartilhamento de bicicletas. Há a indicaçăo das regras para posicionamento das estaçôes no leito carroçável, com sinalizaçăo horizontal e vertical, e nas calçadas, com requisitos para evitar a obstruçăo da passagem de pedestres.

A Instruçăo Normativa SMSUB n02, de 13 de setembro de 2018, reproduzida no Diário Oficial pela Secretaria Municipal das Subprefeituras, previamente publicada em 15 de agosto de 2018, descreve que para a instalaçâo de sistema de compartilhamento de bicicletas, com ou sem estaçăo física é necessária a expediçấo do Termo de Permissâo de Uso (TPU) para a utilizaçăo de vias e logradouros públicos pelas subprefeituras, após autorizaçăo prévia da CET.

Apesar de a instruçăo normativa ser desenvolvida pela Secretaria das Subprefeituras, as subprefeituras năo tomaram conhecimento do assunto e nâo tinham processo nem fluxo organizado e padronizado para a emissăo do TPU. Isso dificultou e atrasou ainda mais a regularizaçăo e o término de instalaçăo das estaçôes de todas as empresas credenciadas.

A Secretaria Municipal de Mobilidade e Transportes publicou a portaria SMT-DSV n0108/2018 em 18 de outubro de 2018, em que explicitava novas regras a respeito da responsabilidade das despesas de projeto e implantaçâo da sinalizaçăo das estaçôes, bem como as normas para entrega de projetos de estaçôes e de distâncias mínimas entre estaçôes da mesma empresa ou de 
empresas distintas, relacionadas ao tamanho da quadra, além de dar informaçôes a respeito da fiscalizaçăo e da aprovaçăo da obra de acordo com o projeto.

A subprefeitura de Pinheiros, em 31 de outubro de 2018, publicou a portaria n 016/PR-PI/GABINETE/2018 de regulamentaçăo do processo administrativo interno para a instalaçâo das estaçôes destinadas à locaçâo de bicicletas, com a indicaçăo de que considera a Lei Orgânica do Município. O artigo 114 dessa lei denota que "os bens municipais poderăo ser utilizados por terceiros, mediante concessâo, permissâo, autorizaçấo e locaçấo social, conforme o caso e o interesse público ou social, devidamente justificado, o exigir."

\subsubsection{Projeto do novo Bike Sampa em 2018}

Segundo relatório do ITDP (2016), em junho de 2015 o sistema realizava a média de 1.792 viagens por dia, funcionava das 6 às 22 horas (com devoluçăo possível 24 horas por dia) e năo havia cobranças periódicas, apenas o custo adicional após sessenta minutos de empréstimo. Os principais problemas do Bike Sampa apresentados pelo ITDP (2016) consistiam na baixa qualidade das bicicletas, falha no funcionamento do sistema, ineficiência da manutençăo, grande distância entre estaçōes (média de 900 metros) e dimensionamento sem consideraçâo da demanda, entre outros. 


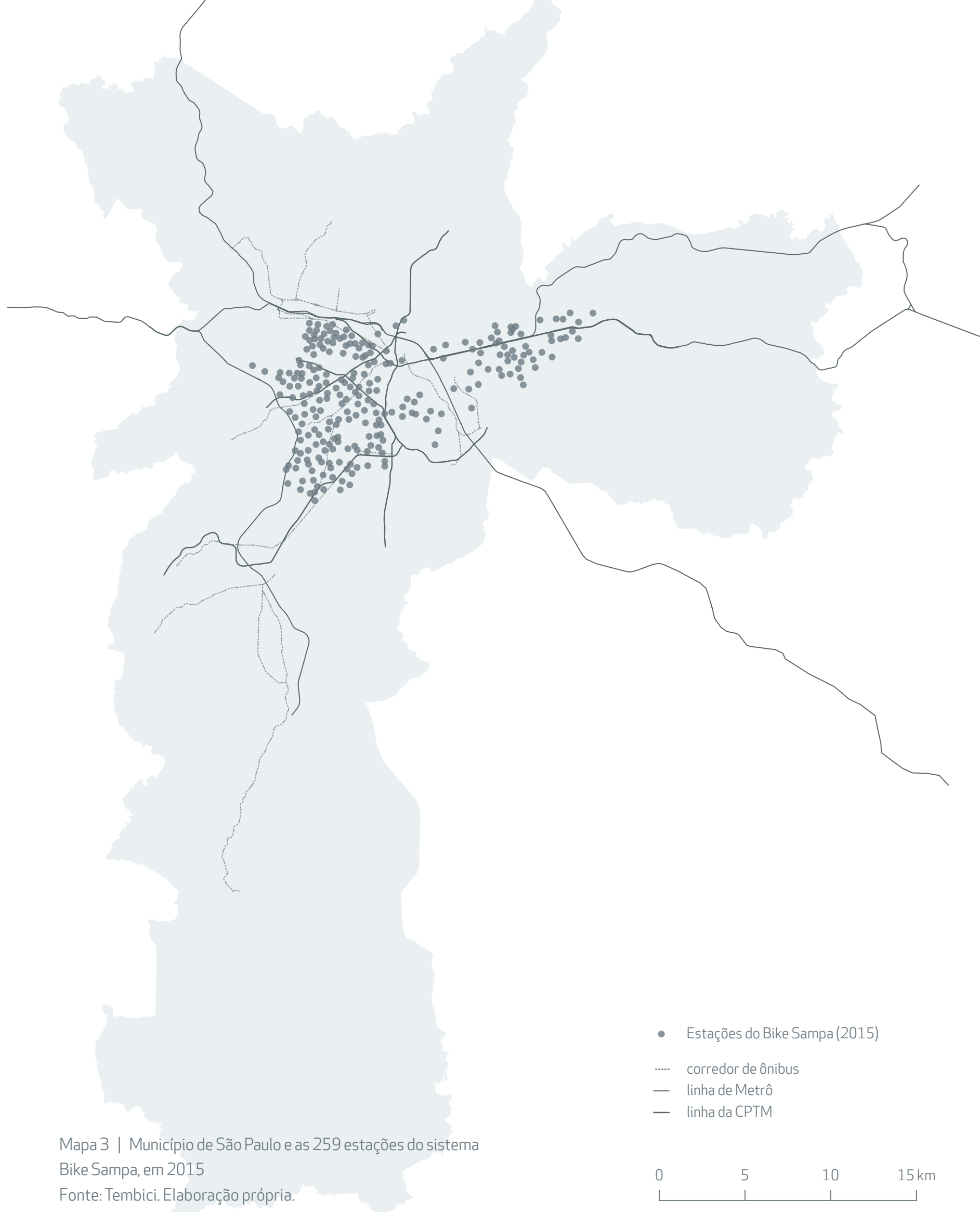


Victor Callil e Daniela Constanza (2018), pesquisadores do CEBRAP, comparam a quantidade de estaçóes e a área de cobertura do sistema e revelam diferentes densidades em cada cidade, com características distintas quanto ao uso das bicicletas, ao tempo e à distância de deslocamento.

\begin{tabular}{|c|c|c|c|c|c|}
\hline Sistema & $\begin{array}{c}\mathbf{N}^{0} \text { de } \\
\text { estações }\end{array}$ & $\begin{array}{c}\text { Área do } \\
\text { sistema } \\
\left(\mathbf{k m}^{\mathbf{2}}\right)\end{array}$ & $\begin{array}{c}\text { Estações por } \\
\mathbf{k m}^{\mathbf{2}}\end{array}$ & $\begin{array}{c}\text { Distância } \\
\text { média entre } \\
\text { as estações } \\
\text { (metros) }\end{array}$ & $\begin{array}{c}\text { Distância } \\
\text { média pedalada } \\
\text { em dias úteis } \\
\text { (metros) }\end{array}$ \\
\hline Bike Sampa & 252 & 125 & 2 & 446 & 2218 \\
\hline Citi Bike & 319 & 50 & 6 & 256 & 1710 \\
\hline Ecobici & 425 & 37 & 11 & 190 & 1648 \\
\hline
\end{tabular}

Tabela 7 | Características dos SPBC, em 2015, em São Paulo, Nova York e Cidade do México Fonte: CALLIL; CONSTANZA (2018).

Segundo o estudo, apesar de o Bike Sampa abranger maior área da cidade, sua articulaçăo é menos consolidada com a malha de transportes estrutural, quando comparada à dos demais sistemas mencionados, o que sugere subutilizaçăo em algumas regiôes. 

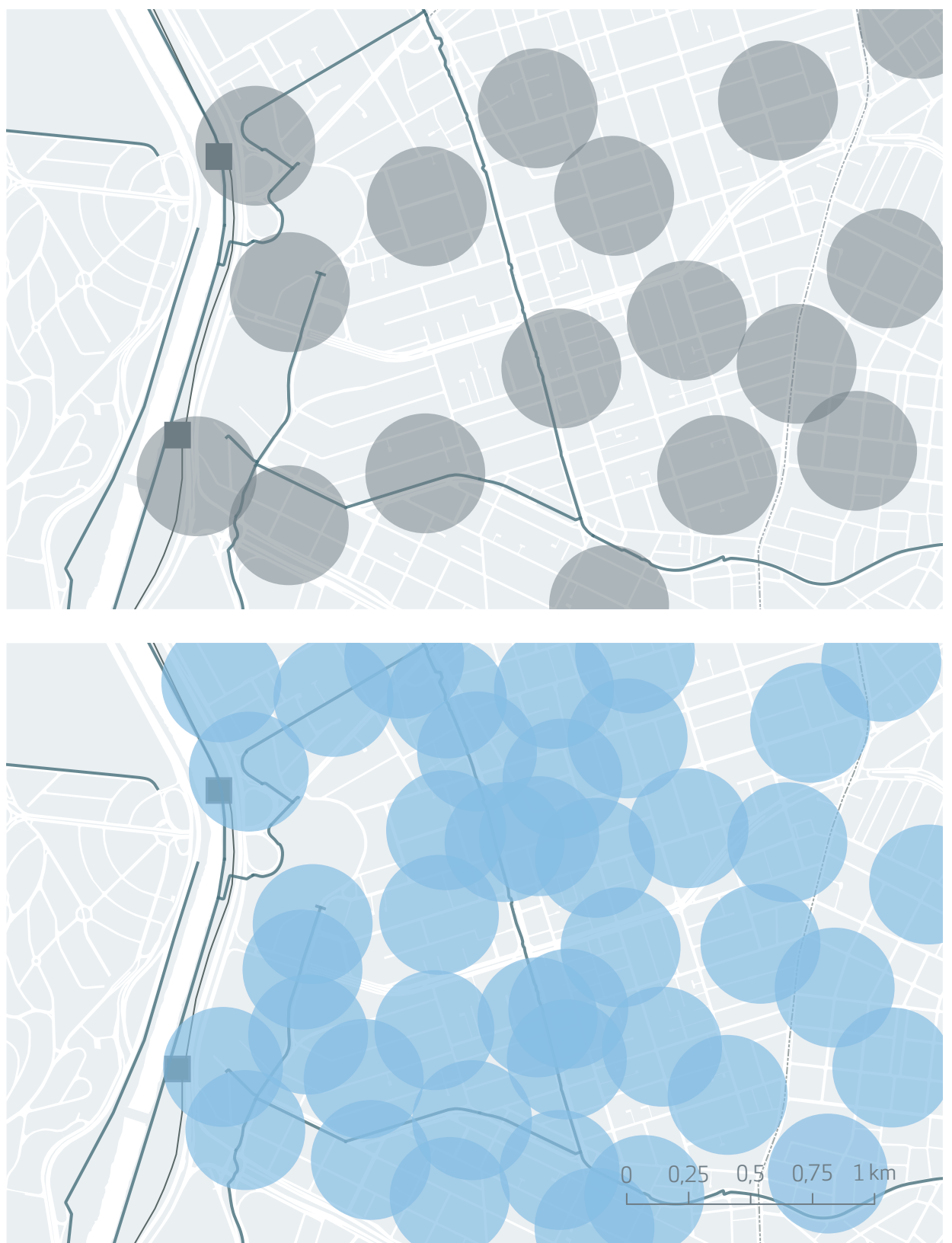

Mapa 4 | Rede de estações na região da Avenida Brigadeiro Faria Lima, em dezembro de 2017 e em dezembro de 2018. Localização das estações indicada com circunferência de raio de 200 metros

Fonte: Tembici. Elaboração própria. 
Como resultado da análise urbana da cidade, com foco na integraçâo modal, da infraestrutura cicloviária e da análise de uso do sistema anterior, formulou-se a nova proposta para o sistema Bike Sampa que será descrita adiante.

Identificou-se que $50 \%$ das estaçóes ocupavam o polígono demonstrado no mapa 5 eram responsáveis por $75 \%$ das viagens totais do sistema. Constatada a baixa densidade da rede de estaçóes, nova área de cobertura foi planejada, com aumento da densidade de duas para seis estaçóes por $\mathrm{km}^{2}$. 
A inauguraçăo do novo Bike Sampa pela empresa operadora Tembici, com o mesmo patrocinador e tecnologia canadense, aconteceu em 30 de janeiro de 2018. Foram 25 estaçôes e 300 bicicletas na fase inicial, na regiăo do Largo da Batata, com autorizaçăo provisória emitida pela Subprefeitura de Pinheiros, da cidade de Sáo Paulo. O sistema antigo, com aproximadamente 250 estaçóes, foi desligado, e no fim de janeiro iniciaram-se as obras de retirada das estaçôes para dar espaço ao novo equipamento.

Algumas diferenças em relaçăo ao sistema anterior podem ser destacadas, como a cobrança de valor dos planos de usuários (com planos de uma viagem, diário, de três dias, mensal e anual), o aumento da relaçăo de vagas por bicicleta e a reformulaçâo do planejamento da localizaçăo das estaçôes. De 1.2 vagas por bicicleta, o sistema passou a contar com 1.8 vagas por bicicleta, o que evita problemas de estaçóes lotadas, mas ocupa espaço maior, e aumenta o desafio de buscar locais na cidade para novos pontos.

A proposta prevê a instalaçăo de 260 estaçōes e 2.600 bicicletas no centro expandido, com a adoçâo de uma nova área de cobertura. A densidade de distribuiçâo das estaçôes, como foi abordado no capítulo 2, é fundamental para o sucesso do sistema de compartilhamento de bicicletas. Haverá também a disponibilizaçăo de mais 500 bicicletas, distribuídas em cinco terminais periféricos, com o compartilhamento de longa duraçâo (doze horas), o que viabiliza a última jornada de bicicleta do terminal à residência e o retorno no dia seguinte, antes da ida para o trabalho. Chamado de "Estaçâo Bike", esse local permite também o estacionamento de bicicletas próprias e contribui, dessa forma, mais ainda para a integraçăo modal. A área de influência das Estaçōes Bike possui circunferência de quatro 
quilômetros, que possibilita a pernoite das bicicletas alugadas na residência dos usuários.

A Ciclocidade (2018b), em nota sobre a inauguraçấo do novo sistema de bicicletas compartilhadas, em janeiro de 2018, revela como pontos positivos do Bike Sampa a adoçáo da tecnologia canadense, que aumentou a confiabilidade; 0 adensamento das estaçóes, apesar da diminuiçăo da área de cobertura, que contribuiu para a efetividade de funcionamento, e possibilitou o atendimento de outras regiôes da cidade com a intermodalidade; e o novo sistema de aluguel de doze horas em terminais na zona periférica da cidade.

Como problemas ainda encontrados, o texto cita o período limitado de funcionamento das 5 às 23 horas $^{14}$ e a expectativa de compromisso com o cronograma apresentado da implantaçăo do sistema completo ${ }^{15}$.

A proposta da nova operadora, Tembici, da qual sou responsável pela área de projetos, consistiu na substituiçấo da tecnologia, com a troca de todas as estaçôes e bicicletas por equipamentos da empresa canadense PBSC, reformulaçấo da operaçăo e novo planejamento da localizaçăo das estaçôes, assim como ocorreu em outras cidades do Brasil.

14 O horário de funcionamento do Bike Sampa foi ampliado em 2018 para 24 horas. 0 aluguel de doze horas do Terminal Cidade Tiradentes funciona de $4 \mathrm{a} 0$ hora.

15 O cronograma não foi cumprido devido à demora da emissão das licenças para o uso do espaço público por parte do poder público. 


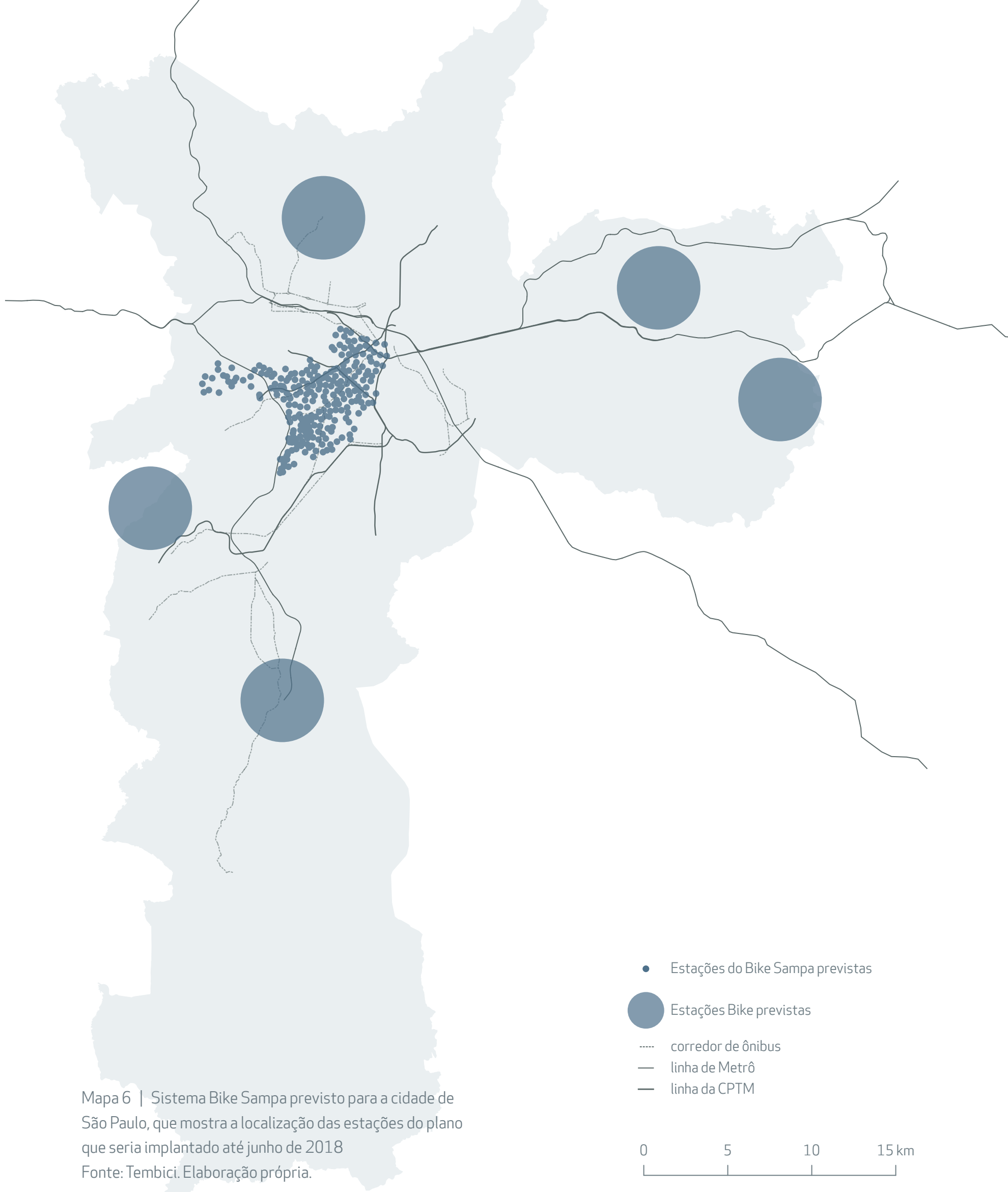




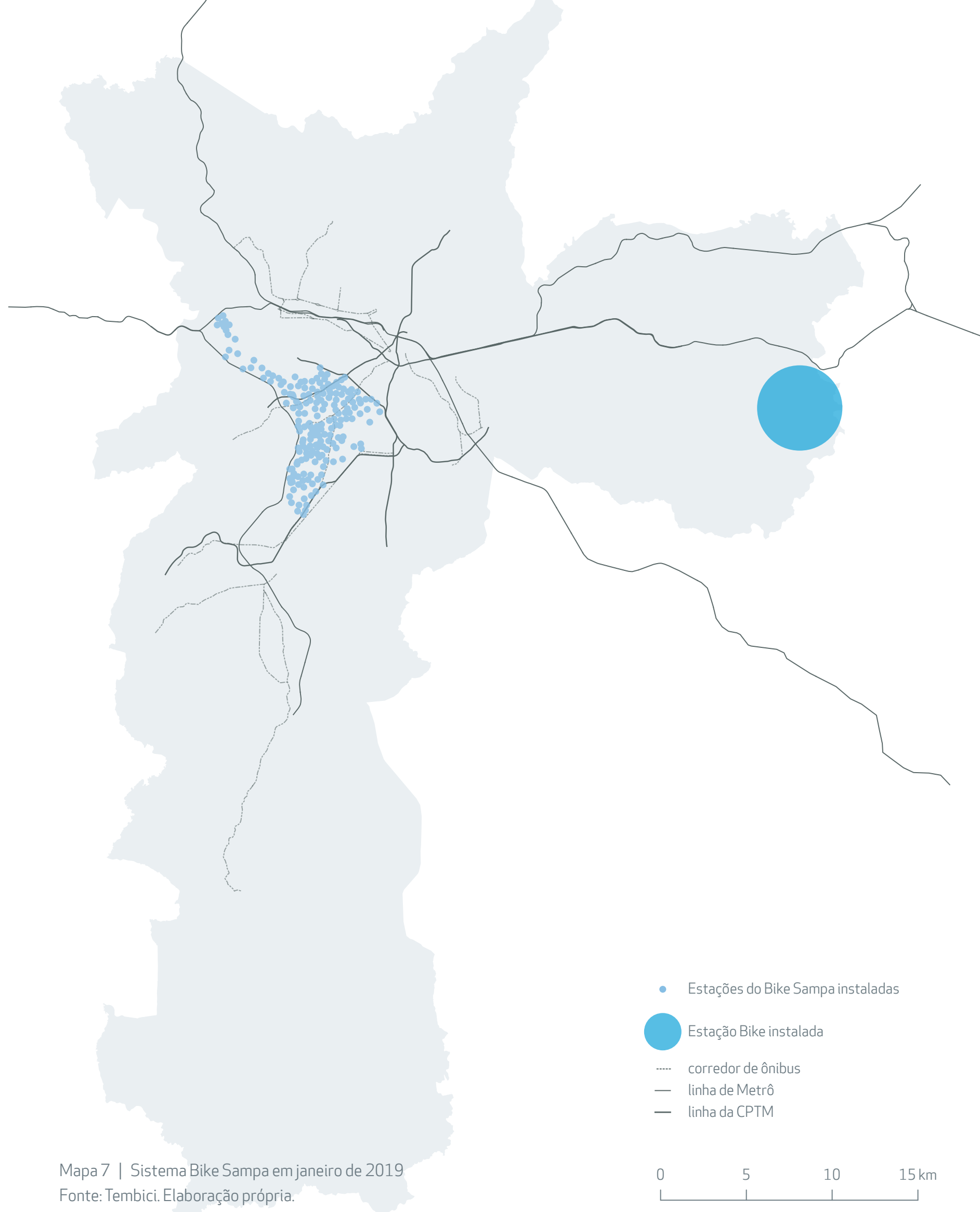


A nova tecnologia permitiu melhorias na interface do usuário e reduziu significativamente a dificuldade na retirada das bicicletas que havia no modelo anterior. O sistema pode ser utilizado com o aplicativo Bike Itaú pelo smartphone, com o Bilhete Único ou com o cartăo de usuário Bike Sampa. É necessário comprar um dos planos disponíveis ${ }^{16}$, que permitem o uso ilimitado pelo período escolhido (com exceçăo da opçăo por viagem), de viagens de até sessenta minutos, com cobrança adicional de $\mathrm{R} \$ 5,00$ a cada hora excedente, para incentivar o compartilhamento das bicicletas.

A compra do plano pode ser realizada via aplicativo ou site com cartăo de crédito ou nos pontos de venda ${ }^{17}$, como no galpăo da operaçăo no Bairro do Cambuci, em espécie, com o cartăo de débito ou boleto bancário, sendo obrigatória a apresentaçâo de documento original com foto e comprovante de residência para o cadastro. $O$ usuário recebe, entăo, seu cartăo para ter acesso ao sistema. Nos demais bicicletários (Estaçăo Bike) da cidade de Sâo Paulo, também é possível realizar a compra dos planos mensal e anual.

Com o plano ativo, para retirar a bicicleta deve-se digitar o código de cinco dígitos gerado pelo aplicativo no painel ao lado esquerdo da doca (vaga) da bicicleta escolhida e a luz verde se acenderá confirmando a liberaçăo. O Bilhete Único, cadastrado no site ou no aplicativo ou o cartâo de usuário Bike Sampa deve ser inserido no lado esquerdo da doca (vaga) da bicicleta escolhida para destravá-la.

16 Uma viagem ( $R \$ 2,00)$; plano diário $(R \$ 8,00)$; plano mensal $(R \$ 20,00)$; plano anual $(\mathrm{R} \$ 160,00)$.

17 Apenas planos mensal e anual. 
Lemos (2018) reconhece os avanços tecnológicos do novo Bike Sampa e o adensamento do sistema proposto, com o intuito de torná-lo atraente na medida em que evita a caminhada de distâncias excessivas para encontrar as estaçôes. No entanto, critica a concentraçăo do serviço na regiấo com maior concentraçăo de renda da cidade, com melhores condiçôes urbanas e oferta de infraestrutura.

\subsubsection{Estação Bike - Empréstimo de longa duração}

Como parte do sistema Bike Sampa, foi implantada a Estaçăo Bike - ponto de estacionamento das bicicletas próprias e de empréstimos de longa duraçăo das unidades do Bike Sampa - localizada em terminal periférico da cidade, numa parceria entre a Tembici, o Itaú e a Prefeitura de Săo Paulo. A primeira a ser inaugurada, em junho de 2018, situa-se no bicicletário do Terminal Cidade Tiradentes da SPTrans, e além de disponibilizar bicicletas para a primeira "perna" da viagem, possui espaço para estacionamento de bicicletas próprias.

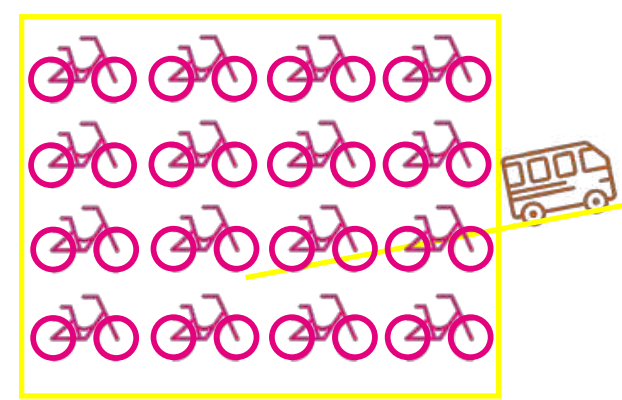

网同囟侖网

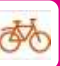

estação bike

área de bike sharing denso

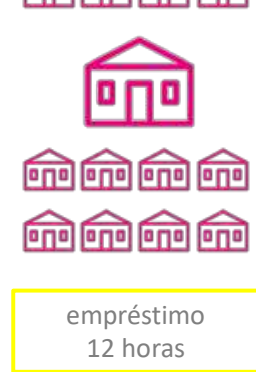

Figura 12 | Esquema de funcionamento do Bike Sampa com a Estação Bike Fonte: Tembici, 2017. 
O espaço funciona das 4 à 0 hora, com funcionários que recebem e vigiam as bicicletas próprias e fazem o empréstimo e a manutençăo das bicicletas do sistema. Os planos sâo os mesmos praticados no centro expandido e possibilitam o uso tanto no começo quanto no final do percurso, com a integraçăo modal. A diferença está no período de gratuidade: enquanto no centro expandido o limite é de sessenta minutos, na Estaçăo Bike pode-se dispor da bicicleta por até doze horas sem custo adicional. Assim, o usuário pode levar a bicicleta para casa e devolvê-la no dia seguinte. O intervalo para o empréstimo sem cobrança adicional é de três horas, diferente dos quinze minutos no resto do sistema.

A compra pode ser realizada no local, por meio de boleto bancário ou cartâo de débito, com a obrigatoriedade de apresentaçâo de documento original com foto e comprovante de residência. A retirada e a devoluçăo, sempre a cargo de funcionários que ficam no local, podem ser efetuadas com o cartăo de usuário, sem a necessidade do aparelho celular.

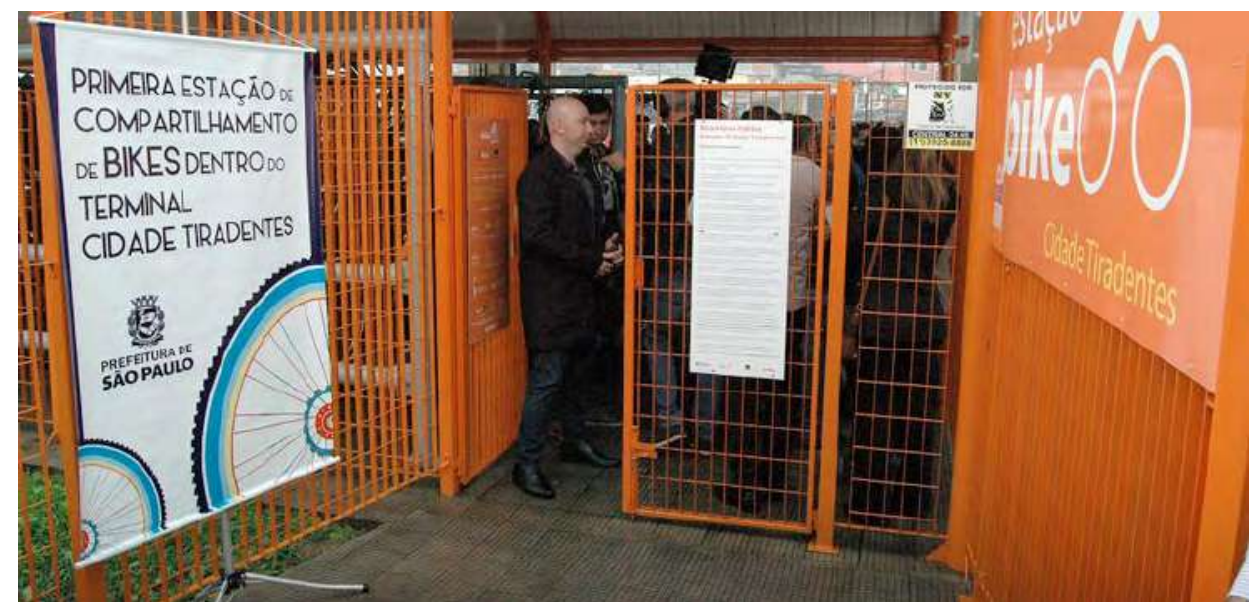

Foto 34 | Entrada do bicicletário Estação Bike Cidade Tiradentes Fonte: Luiz Guadagnoli/SECOM. 


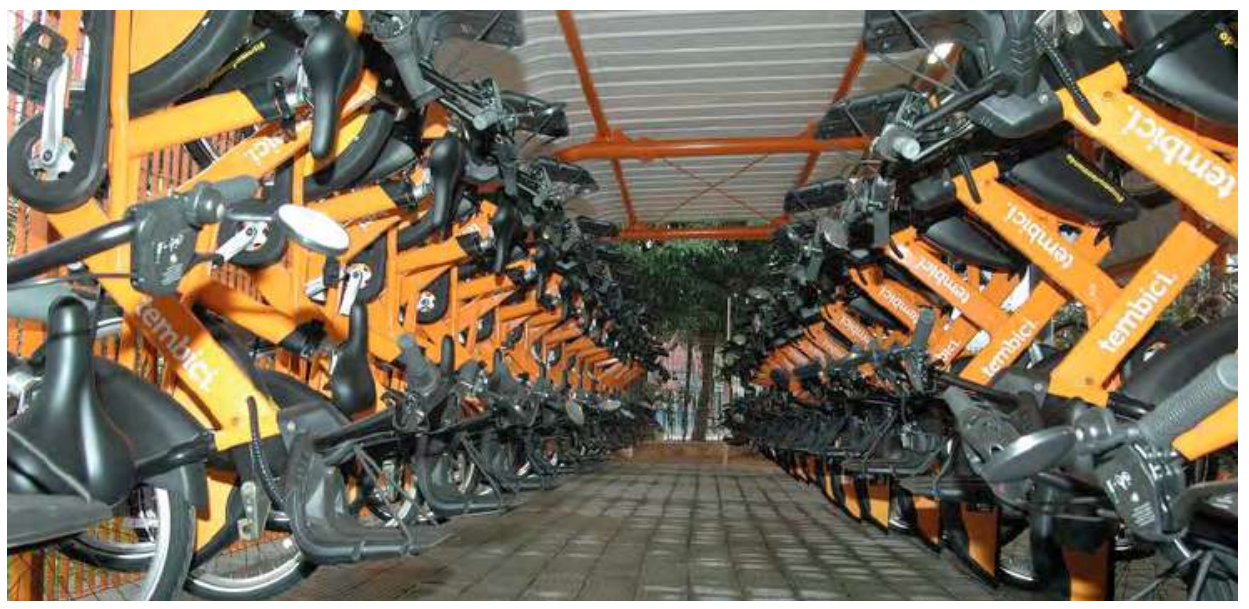

Foto 35 | Estação Bike Cidade Tiradentes

Fonte: Luiz Guadagnoli/SECOM.

Ainda em fase de implantaçăo, os empréstimos de longa duraçăo estâo previstos em outros quatro pontos periféricos da cidade. Espera-se, em 2019, inaugurá-los nas zonas norte, sul e leste do município. Com início de funcionamento em junho de 2018, a Estaçăo Bike Cidade Tiradentes enfrentou problemas de vandalismo e algumas surpresas no processo de adaptaçáo por parte da comunidade local.

O acontecimento mais inesperado foi a demanda massiva no período do dia para lazer por jovens da regiăo. O mau uso das bicicletas prejudicou a integridade física do equipamento e, na devoluçăo, sempre havia peças quebradas, desgastadas ou roubadas. Pelo tempo disponível de doze horas sem custo adicional, a bicicleta năo era compartilhada ao longo do dia, e năo havia unidades para empréstimo no fim da tarde, para o retorno do trabalho. O fato de năo existir sistema de cadeado para guardá-la em casa e a possibilidade de devoluçâo no dia seguinte também desincentivaram a modalidade, 
pois muitas pessoas moram em edifícios sem elevador e năo conseguem levá-la para dentro de sua residência.

Algumas açôes foram realizadas para contornar esses problemas, como a vistoria na retirada e na devoluçăo e a necessidade de aguardar três horas para retirar uma nova unidade.

Além disso, com o objetivo de aproximar-se da comunidade local e disseminar a cultura da bicicleta no território, foram promovidas atividades sociais de integraçăo do Bike Sampa pela organizaçăo Instituto Aromeiazero ${ }^{18}$, que se juntou ao projeto para desenvolver a estratégia de engajamento comunitário, de forma a destacar o papel da bicicleta além da mobilidade, com potencial de reduzir as desigualdades e otimizar o direito do habitante ao usufruto da cidade.

Para facilitar o diálogo e formar comunicadores no bairro, desenvolveu-se a cartilha para embaixadores, com a finalidade de incentivar as práticas do compartilhamento e o bom uso das bicicletas (figura 13). Outras açōes foram realizadas, como aulas abertas de mecânica e aula para iniciantes do pedal, financiamento de projetos comunitários e outros eventos. A videorreportagem do Bike é Legal “Bikes Compartilhadas chegam à periferia"19, de 7 de novembro de 2018, apresenta mais informaçôes sobre o trabalho feito na Estaçăo Bike Cidade Tiradentes.

18 O Instituto Aromeiazero é uma organização sens fins lucrativos que visa promover qualidade de vida e inovação social por meio da bicicleta e sua ocupação nas ruas. Mais informações disponíveis em: <www.aromeiazero.org.br>. Acesso em: 26 jan. 2019.

19 Videorreportagem do Bike é Legal. Disponivel em: <https://www.youtube.com/watch?$\mathrm{v}=\mathrm{X} 3 \mathrm{TCHrS|} \mid \mathrm{rg} \& \mathrm{t}=72 \mathrm{~s}>$. Acesso em: 31 jan. 2019. 
No segundo semestre de 2018, o Fundo de Apoio da Bicicleta Ediçăo Cidade Tiradentes ${ }^{20}$ (FAB CT), com iniciativa do Aromeiazero, patrocínio do Itaú e apoio da Tembici, abriu edital para participantes residentes no bairro para buscar iniciativas e propostas, de até R\$2.000,00 e duraçăo máxima de dois meses, que fortalecessem o uso da bicicleta em Cidade Tiradentes.

Os projetos selecionados organizaram pedaladas, voltadas principalmente para mulheres, e criaram a Oficina Mecânica Comunitária no Centro de Formaçâo Cultural (coletivo "A Rua é Delas"); organizaram eventos para ensinar as mulheres a pedalar e debates sobre mulher e mobilidade (projeto "Mulher Vem pra Rua", da Casa Anastácia); e customizaram as bicicletas do Bike Sampa (projeto Arte na Bike), pelo coletivo de graffiti de Cidade Tiradentes, chamado Operaçăo Tinta no Muro. Essas bicicletas ficaram durante um mês em exposiçăo no Terminal de Ônibus e depois foram disponibilizadas para empréstimo.

Em 9 de dezembro de 2018, aconteceu o Festival Estaçâo Bike, evento de celebraçăo da bicicleta em Cidade Tiradentes, com apresentaçôes musicais, rodas de leitura, oficina mecânica comunitária, aula de pedal para crianças e adultos, pedaladas no bairro e oficina de graffiti.

20 FAB edição Cidade Tiradentes. Disponível em: https://www.aromeiazero.org.br/fabct. Acesso em: 15 jan. 2019. 


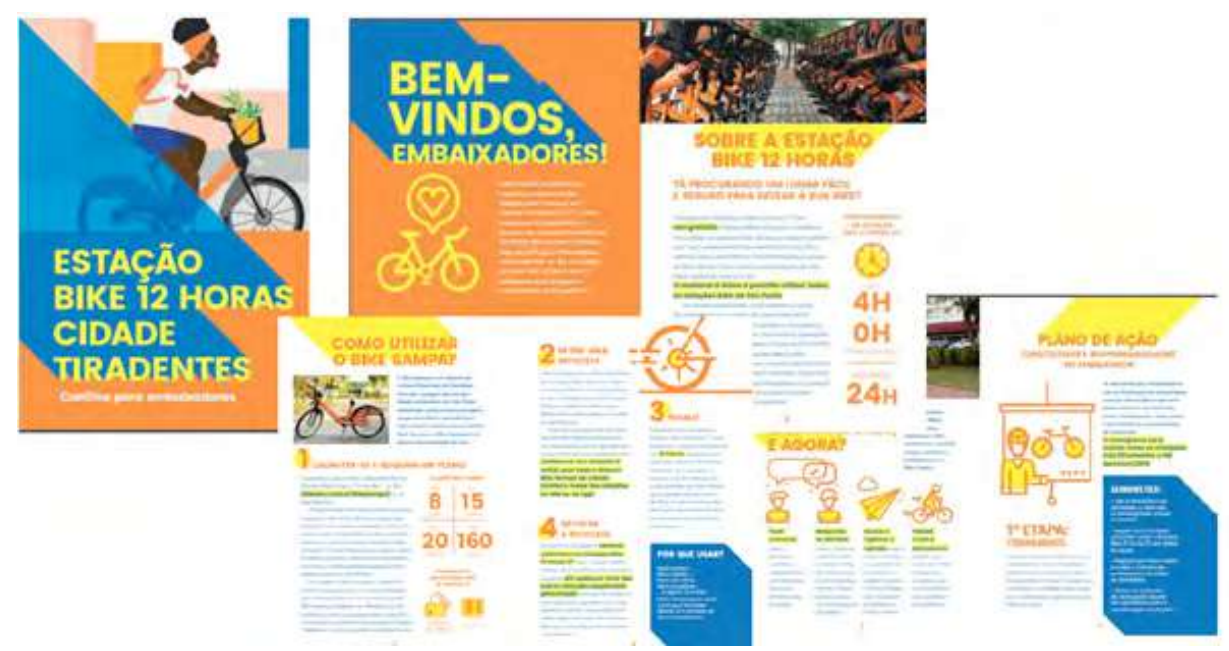

Figura 13 | Cartilha para embaixadores da Estação Bike 12 horas Cidade Tiradentes Fonte: Aromeiazero, Itaú e Tembici.

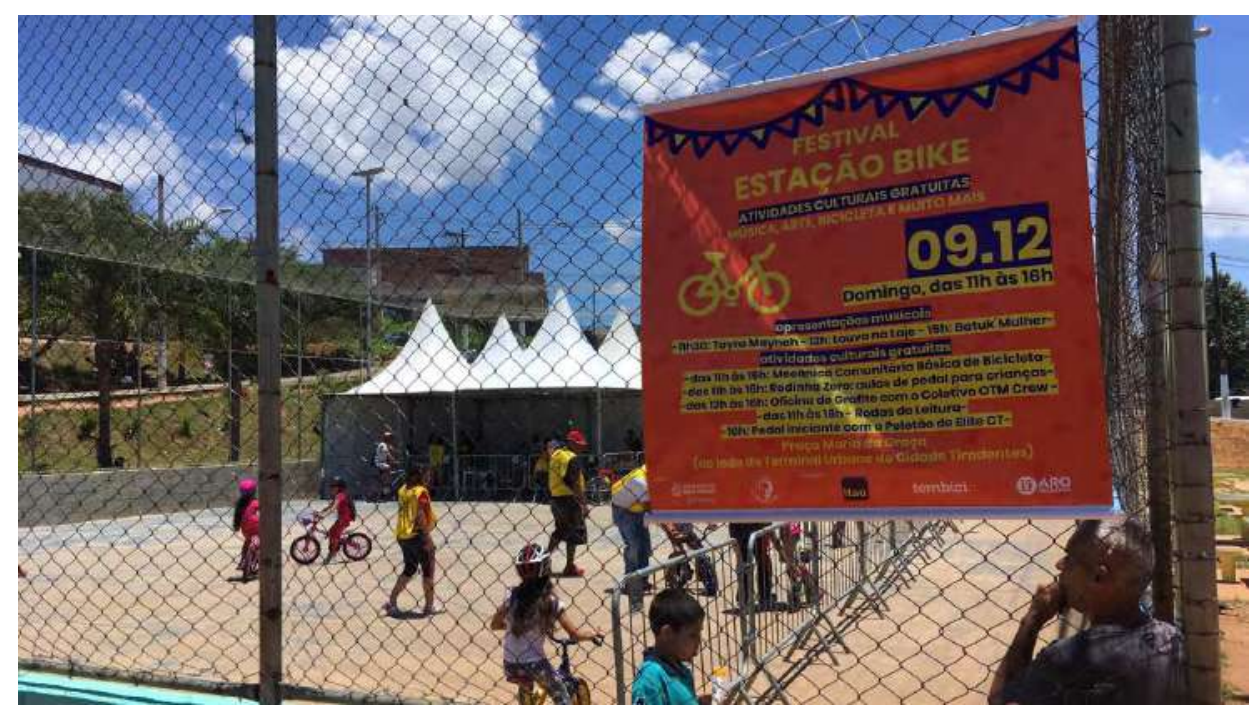

Foto 36 | Festival Estação Bike Cidade Tiradentes, em 9 de dezembro de 2018

Fonte: Aromeiazero. 


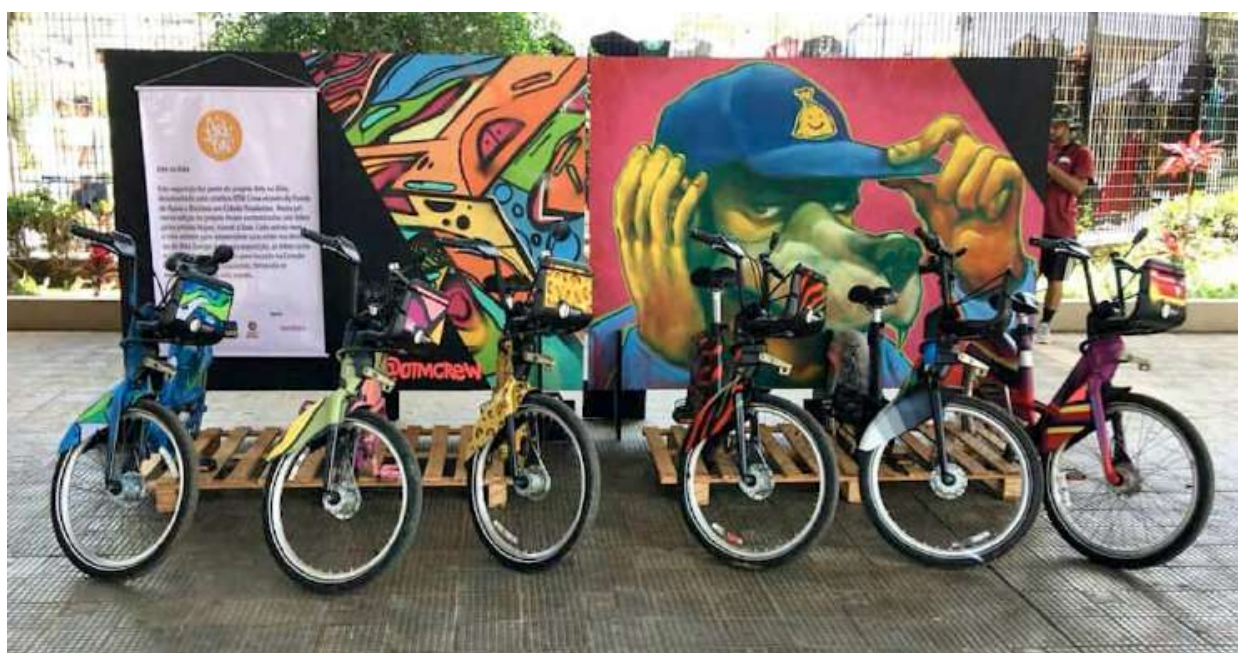

Foto 37 | Bicicletas customizadas, pelo coletivo OTM, do projeto Arte na Bike selecionado no FAB-CT Fonte: Picdeer Aromeiazero.

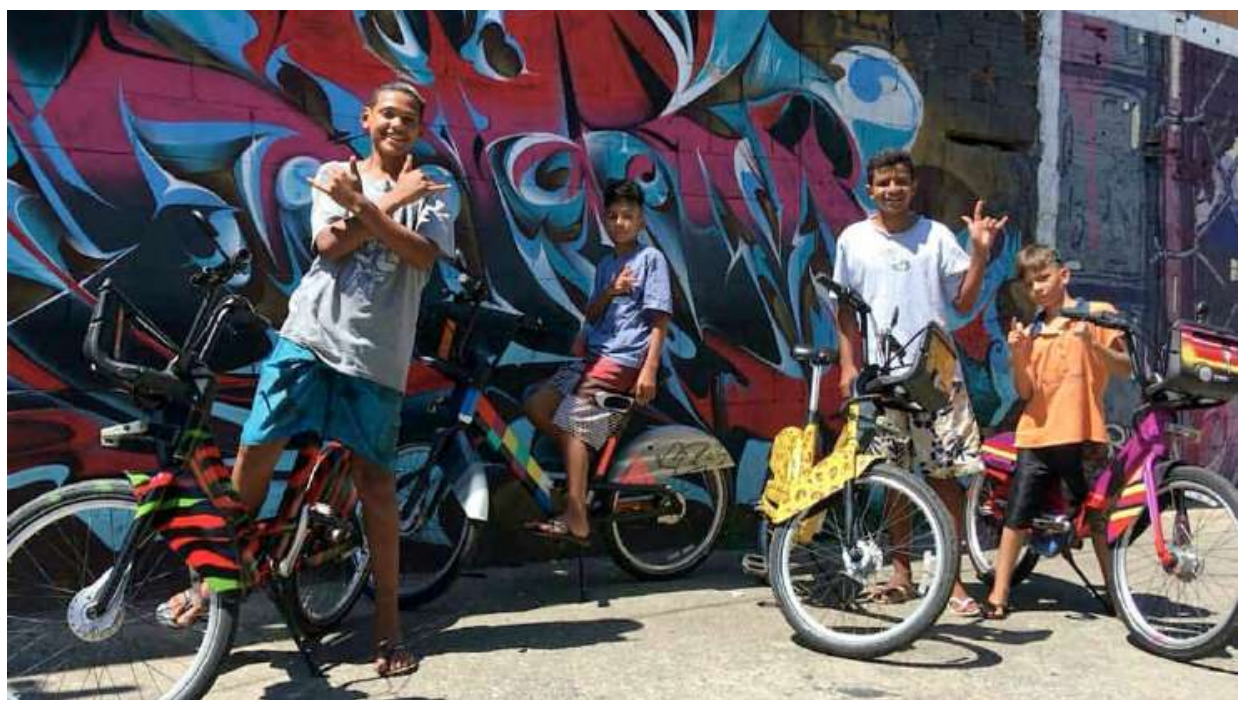

Foto 38 | Bicicletas customizadas compartilhadas da Estação Bike Cidade Tiradentes Fonte: Picdeer Aromeiazero. 
A reportagem do SPTV (Globo) ${ }^{21}$, de 25 de janeiro de 2019, fala sobre os problemas da mobilidade na cidade de Sáo Paulo. Entre os minutos 4:13 e 4:52 apresenta-se o caso de uma cliente do Bike Sampa de Cidade Tiradentes que utiliza a bicicleta diariamente no deslocamento da casa para o terminal de ônibus.

O Instituto Aromeiazero, com patrocínio do Itaú, realizou o documentário Estaçăo Bike 12 Horas de Cidade Tiradentes ${ }^{22}$, transcrito a seguir, que fala sobre o uso das bicicletas desse sistema.

21 Reportagem disponivel em:<https://globoplay.globo.com/v/7329939/programa/>. Acesso em: 26 jan. 2019.

22 Documentário disponível em: <https://www.youtube.com/watch?v=E8Q0vKNkAQI>. Acesso em: 15 jan. 2019. 


\section{Estação Bike 12 Horas de Cidade Tiradentes}

Em junho de 2018, Cidade Tiradentes recebeu a primeira estaçáo de compartilhamento dentro de um terminal de ônibus em Sáo Paulo. A 35 quilômetros do centro, extremo leste da cidade, a Estaçăo Bike 12 Horas permite que os usuários fiquem doze horas com a bicicleta pelo preço de uma hora.

"Eu fiquei sabendo do Bike Sampa através de dois meninos que estavam passando e vi também na reportagem."

Kauê Lima da Cruz, estudante, 16 anos

"Eu moro aqui há bastante tempo, eu passei por lá e sempre via."

THAis DE O. SA, EMPREENDEDORA, 36 ANOS

"Eu fiquei sabendo do projeto porque mudou as cores do lugar e tava a divulgaçâo lá que ia ser esse projeto, e aí eu achei interessante." José RoBerto, PADEIRO, 47 ANOS

“Depois do Bike Sampa mudou muita coisa na nossa vida, porque, entre aspas, nossa vida é só no bicicletário agora, é nossa segunda casa. Ninguém nunca imaginou que na comunidade, favela, iria ter um negócio desse. E quando veio, veio para ajudar os moradores, trabalhadores."

KaUê Lima da CRUz

"Muita gente năo tem bike".Kauê Lima da Cruz: “E nâo tem condiçôes de comprar uma."

IgOR LiMA DA CRUZ, ESTUdANTE, 18 ANOS

"Năo tem nenhum projeto para diversăo, entăo, eu fiquei surpreso. A bicicleta representa para mim qualidade de vida, tira o seu estresse." JosÉ ROBERTO 
“Na verdade eu vinha sempre de carro para o meu trabalho. Entăo agora, no caso, eu pego a bike, para mim fica bem mais prático. Quando eu venho de carro, eu fico parada no trânsito e quando eu venho de bike eu consigo chegar bem mais rápido.

THAis DE O. SA

“Já tem uns trinta anos que eu ando de bike e no meu caso, como hipertenso e na obesidade, é necessário fazer um exercício, entăo eu preferi a bike, porque é uma bike muito boa, é leve, confortável, tem os equipamentos de segurança (lanterna traseira, lanterna da frente)." JosÉ ROBERTO

"Ainda há um grande número de manutençâo, porque a molecada anda em vias que tem morro, tem escada, fica subindo e descendo de guia. A molecada tem uma energia que só Deus sabe, acaba tendo esses tipos de danos.

Marcos Ferreira, embaixador Estaçăo Bike 12 Horas CT

“Pessoal, vamos manter a bicicleta que é para o nosso uso mesmo, e sempre quando falta, é muita hora de espera, a manutençâo às vezes demora de vir, e nós mesmos que sofremos."

KAUÊ Lima dA CRUZ

"Aí a gente chega lá para poder pegar a bike e năo tem, porque estấo quebradas, porque estăo sem freios."

THAis DE O. SA

"Entăo eu acho que a populaçấo devia conscientizar e cuidar melhor como se fosse seu."

JosÉ ROBERTO

"Andem de bike, aproveitem porque é muito bom."

KaUÊ Lima da CRUZ 


\subsubsection{Análise quantitativa do Bike Sampa}

Os dados do BikeSampa, desde a inauguraçăo em 2012 até janeiro de 2019, completado um ano do novo sistema, sâo mostrados a seguir. A operaçáo do sistema foi feita pela Serttel até maio de 2017, quando ocorreu sua substituiçăo pela Tembici, que opera o sistema até a presente data ${ }^{23}$. As informaçôes sobre o Bike Sampa foram extraídas da base de dados do sistema da Tembici.

A partir de 2015, houve reduçấo do número de bicicletas do sistema, o que levou rapidamente à diminuiçấo do volume de viagens totais e viagens por dia entre 2016 e 2017 . 0 ano de 2017 teve queda muito acentuada no número de viagens. Além do encolhimento da quantidade de bicicletas, o processo de compra e venda da empresa operadora dos sistemas, que culminou com a consolidaçăo da aquisiçăo em maio de 2017, influenciou a qualidade da operaçăo nesse período.

Apesar dos resultados extremamente baixos em relaçáo às viagens desse período (abril de 2017 a abril de 2018), o que ocasionou momento muito difícil para a confiabilidade do sistema, optou-se por passar por essa fase complicada de adaptaçấo, pois o serviço já vinha com problemas de baixa qualidade de operaçăo, atestado pela queda de uso desde 2016. 0 patrocinador, ao reconhecer as dificuldades, apoiou a troca de empresa operadora, apesar das complicaçôes que o sistema apresentaria no período, em aposta

23 A Tembici comprou a empresa Samba, que era controlada pela Serttel, e tinha os contratos firmados de operação dos sistemas públicos de bicicletas compartilhadas com o poder público de cada cidade ou estado. 
na melhora futura consequente à troca de tecnologia, ao novo planejamento urbano e aos processos de logística e manutençăo.

O risco que o sistema correu nesse tempo era grande pelo baixo uso, pela rejeiçăo e devido ao elevado volume de reclamaçōes dos usuários. Havia muito receio quanto à recuperaçâo da confiabilidade. Os problemas apresentados pelo sistema antigo eram diversos, como a falta de bicicletas, pouca manutençăo das que estavam disponíveis, contratempos para retirar o veículo pelo aplicativo, entre outros.

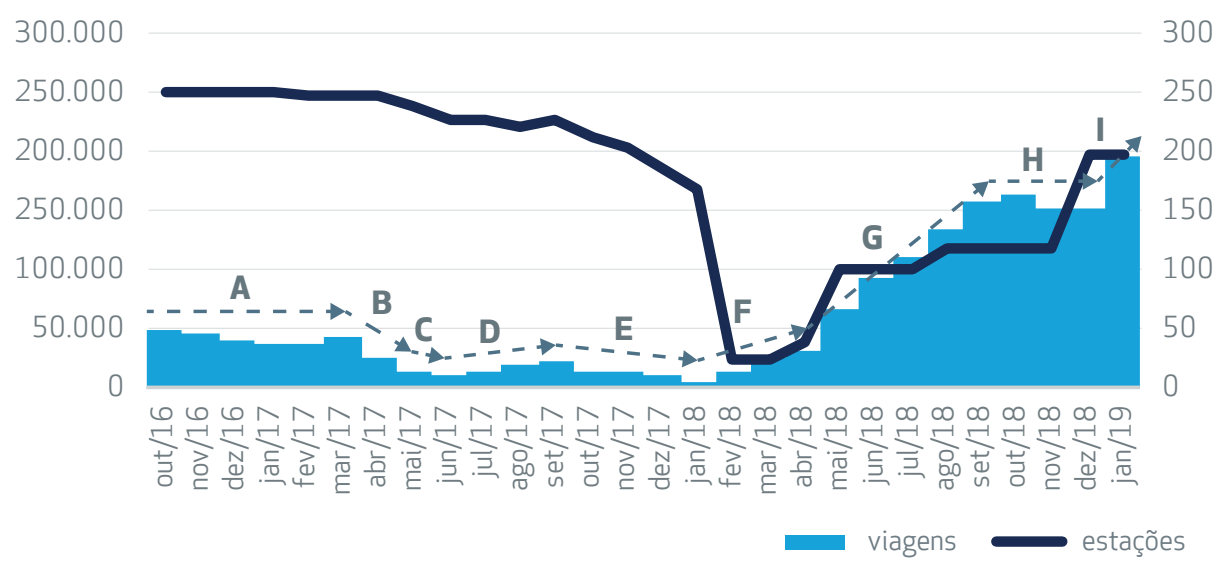

Gráfico 24 | Relação entre o número de estações do Bike Sampa e as viagens mensais, de outubro de 2016 a janeiro de 2019

Fonte: Tembici. Elaboração própria.

No gráfico 24, explicita-se o número de viagens mensais do Bike Sampa, dividido por períodos de diferentes tendências relacionados à operaçăo do sistema. O processo de mudança da empresa operadora influenciou o baixo uso no período de quase um ano (entre abril de 2017 e abril de 2018). 
$-A$

A média mensal nos seis meses entre outubro de 2016 e março de 2017 era de 40 mil viagens, com pequenas variaçóes sazonais. Em março de 2017, houve 42 mil viagens, enquanto março do ano anterior (2016) teve $66 \mathrm{mil}$ viagens, o que revela certa decadência no uso do sistema, com queda de $36 \%$.

$-B$

A finalizaçăo da negociaçăo da empresa possivelmente contribuiu para a queda de uso de aproximadamente 70\% entre março e maio de 2017, de 42 mil para 13 mil viagens no mês.

\section{$-\mathrm{C}$}

Os trâmites burocráticos de compra da empresa, incorporaçăo de funcionários e processos provocaram um dos piores meses do Bike Sampa, com 10 mil viagens em junho de 2017.

$-D$

A adiçâo de mais bicicletas ao sistema entre julho e setembro ocasionou a tendência de aumento do número de viagens, que chegou a quase $23 \mathrm{mil} \mathrm{em}$ setembro de 2017.

E

A partir de outubro, porém, houve outra queda no uso, devido ao elevado número de casos de vandalismo e roubo das bicicletas nas estaçôes. Como a troca de tecnologia já estava prevista para o início do ano seguinte, a empresa optou por náo investir em comprar novas bicicletas. Janeiro de 2018 teve o pior desempenho, por se tratar do período de pré-inauguraçăo da nova tecnologia, com a retirada das estaçóes do formato antigo. 
F

A inauguraçăo do novo sistema, com 25 estaçôes, ocorreu em 30 de janeiro de 2018. De fevereiro a abril de 2018, registrou-se aumento de 13 mil para 32 mil (2,5 vezes) no número de viagens. Esse resultado é maior do que o de abril do ano anterior, com apenas quarenta estaçôes, em comparaçấo com as 250 existentes em 2017.

$-G$

Em maio de 2018, o Bike Sampa passou a contar com 101 estaçôes, o que acarretou um salto no número de viagens, de 32 mil para 68 mil e aumento por volta de $20 \%$ ao mês de maio a setembro do mesmo ano.

$-\mathrm{H}$

De setembro a dezembro de 2018 o sistema atingiu certa estabilizaçăo com117 estaçôes e apresentou variaçôes sazonais devido ao elevado número de feriados, em novembro e dezembro.

$-1$

Em dezembro, houve novas instalaçōes, e o número atingiu quase 200 estaçôes. $\mathrm{O}$ aumento de estaçôes e bicicletas começa a apresentar seus efeitos a partir de janeiro de 2019. 
Em janeiro de 2019, o Bike Sampa anotou a média de 7.000 viagens por dia útil e 4.000 por fim de semana, o que representa aumento de $500 \%$ em relaçâo ao total de janeiro de 2017.

O Bike Sampa registra o pico da tarde (retorno do trabalho) maior do que o pico da manhá (ida ao trabalho) nos dias de semana, com caráter pendular de viagens ao trabalho, representado pela evidência dos horários de maior uso da manhá e do final do dia, com queda brusca no meio do período (entre 10 e 16 horas) e nos fins de semana (gráfico 25). O padrâo de uso ao longo do dia assemelha-se ao mostrado no gráfico 10 (item 2.4) para sistemas de bicicletas compartilhadas com estaçôes, conforme estudo da NACTO (2017).

Quando se analisa o uso diário por gênero, nota-se maior proporçăo masculina em todos os horários e em todos os dias da semana (gráficos 26 e 27). Durante a semana, janeiro de 2019 apresentou 75\% de viagens realizadas por homens, enquanto nos fins de semana o índice diminuiu para 71\%. Apesar de a proporçâo das mulheres usuárias de bicicletas compartilhadas ser maior do que o índice de $10 \%$ de mulheres ciclistas da Pesquisa de Origem e Destino do Metrô de 2007 (MALATESTA, 2014, p. 64), essa porcentagem ainda continua muito baixa, o que indica menor adesăo das mulheres ao uso da bicicleta no ambiente urbano. 


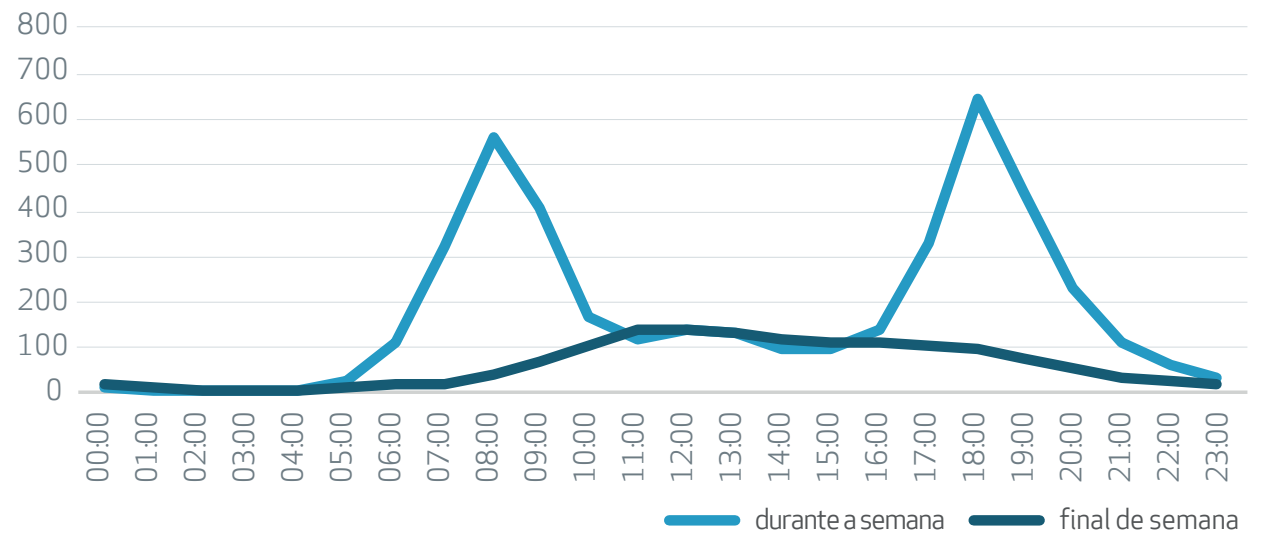

Gráfico 25 | Viagens por hora por dia no mês de janeiro de 2019 no Bike Sampa Fonte: Tembici. Elaboração própria.

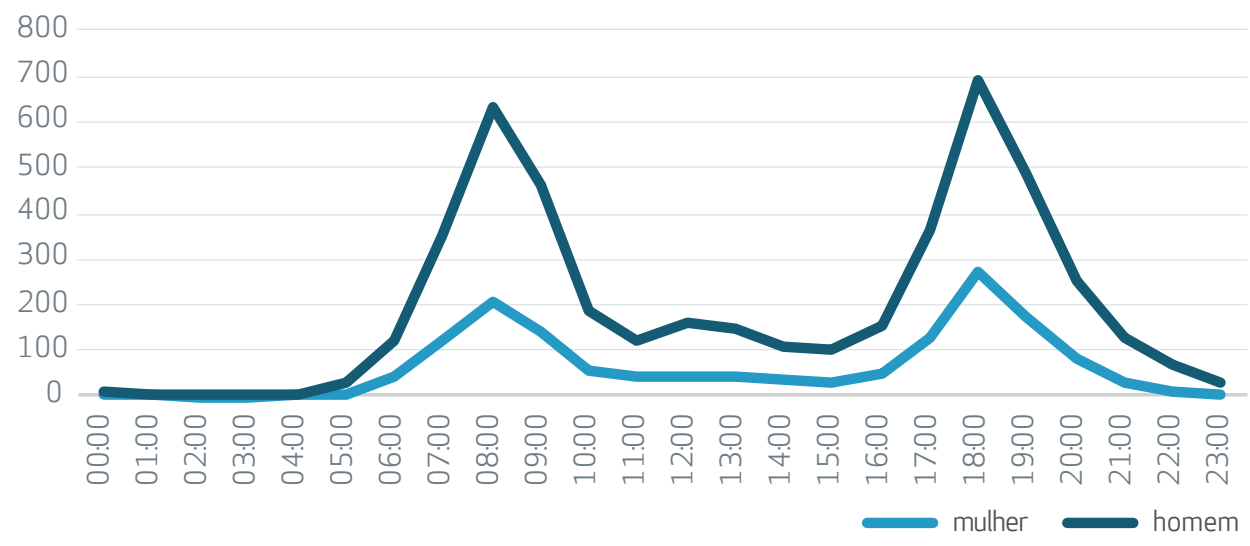

Gráfico 26 | Viagens por hora por dias de semana no mês de janeiro de 2019 no Bike Sampa, por gênero

Fonte: Tembici. Elaboração própria. 


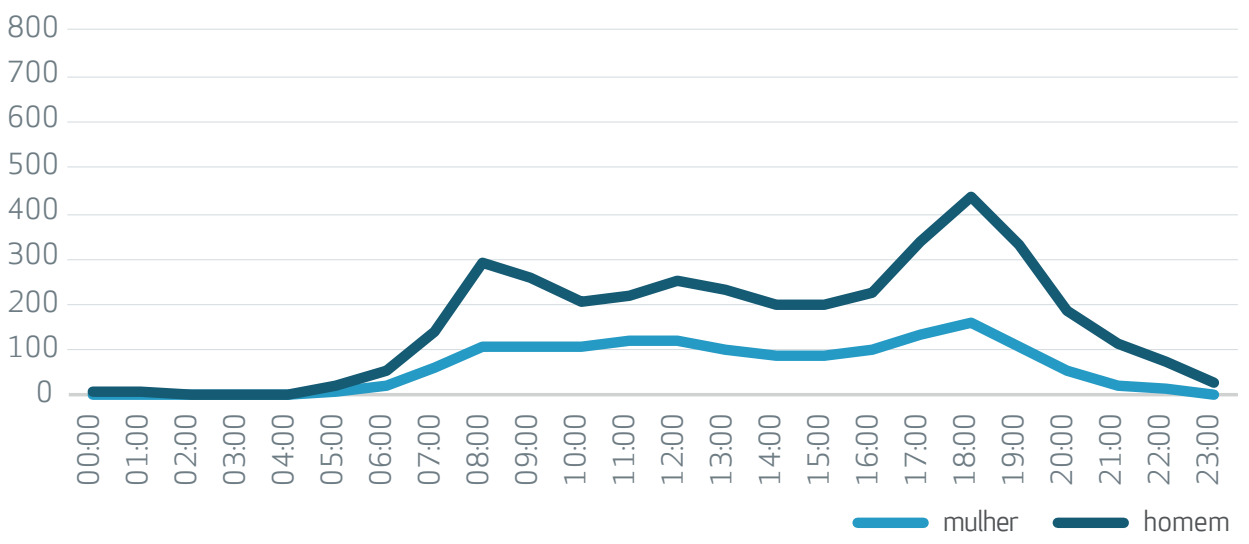

Gráfico 27 | Viagens por hora por dias de fim de semana no mês de janeiro de 2019 no Bike Sampa, por gênero

Fonte: Tembici. Elaboração própria.

Os gráficos 28 e 29 identificam a moda ${ }^{24}$ da duraçăo das viagens de todos os sistemas e especificamente do Bike Sampa. No primeiro, a moda é de oito minutos, com alta concentraçăo no número de pessoas que realizam curtos trajetos de deslocamento e diminuiçâo acentuada da quantidade de pessoas com viagens de duraçấo entre dez e 25 minutos. A segunda queda intensiva é visível próximo aos sessenta minutos, fim do período sem cobrança adicional dos sistemas. Pode-se supor, com essa evidência, que há maior probabilidade de que essas viagens mais longas sejam de lazer (e năo de deslocamento), pelo término estar vinculado ao período de uso de gratuidade do sistema.

No caso do Bike Sampa, a moda é de dez minutos e há poucas viagens com duraçâo de mais de vinte minutos, o que evidencia o uso massivo de

24 Moda é o dado mais frequente de um conjunto. 
deslocamentos curtos para o trabalho. A opçáo de lazer costuma estar associada às viagens longas ou com retirada e devoluçáo na mesma estaçáo.

A média de duraçăo das viagens também pode ser calculada em ambos os casos, sendo 23 minutos no caso do Bike Sampa e 26 minutos na soma de todos os sistemas. A média é mais alta que a moda devido às viagens longas, que, apesar de aparecerem em menor quantidade por faixa horária, elevam a somatória final. Para identificar a quantidade de viagens mais realizadas por duraçấo, a moda representa de maneira mais clara a informaçăo. 


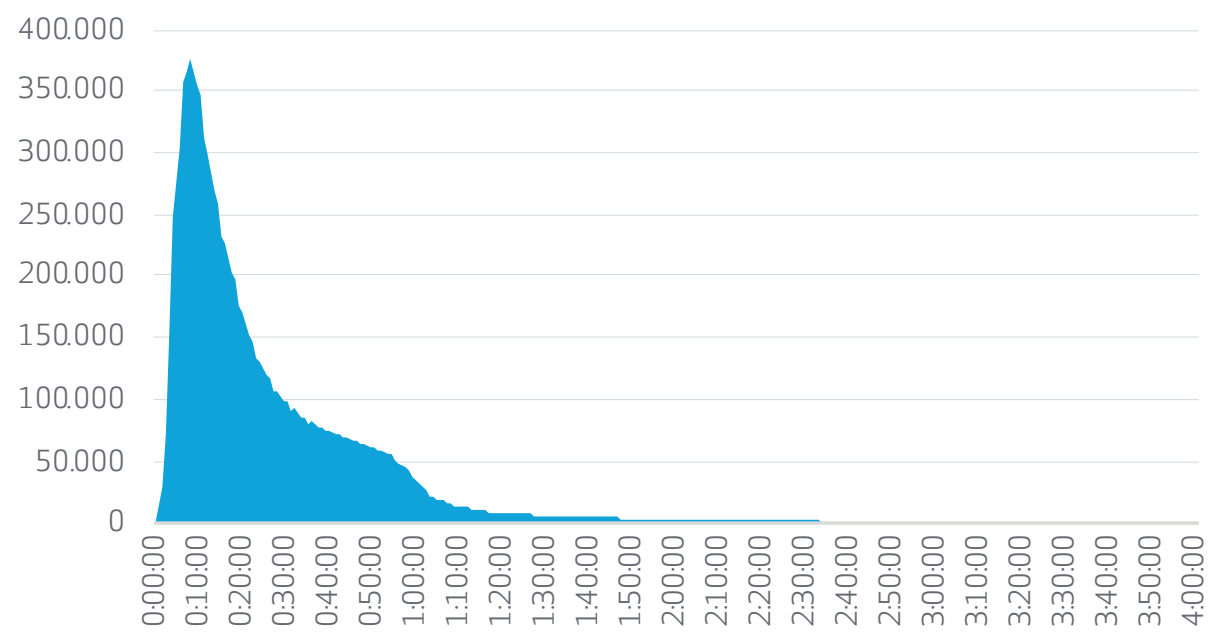

Gráfico 28 | Moda da duração das viagens dos sistemas brasileiros (Bike Sampa, Bike Rio, Bike PoA, Bike Salvador, Bike PE e Bike VV)

Fonte: Tembici. Elaboração própria.

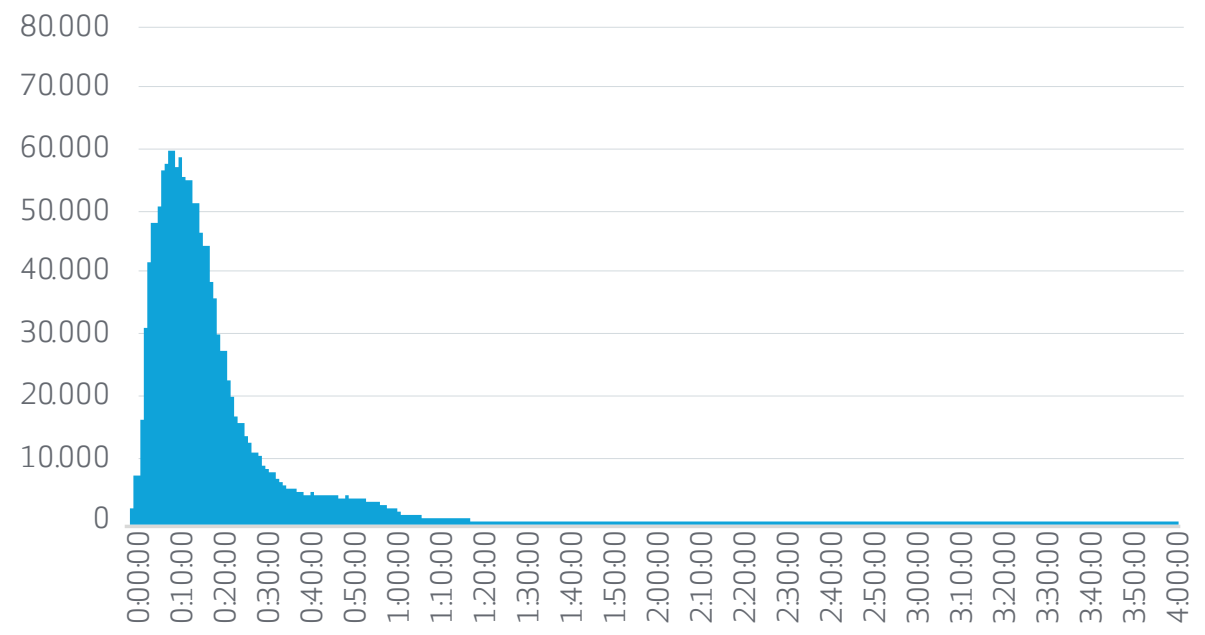

Gráfico 29 | Moda das viagens do Bike Sampa

Fonte: Tembici. Elaboração própria. 


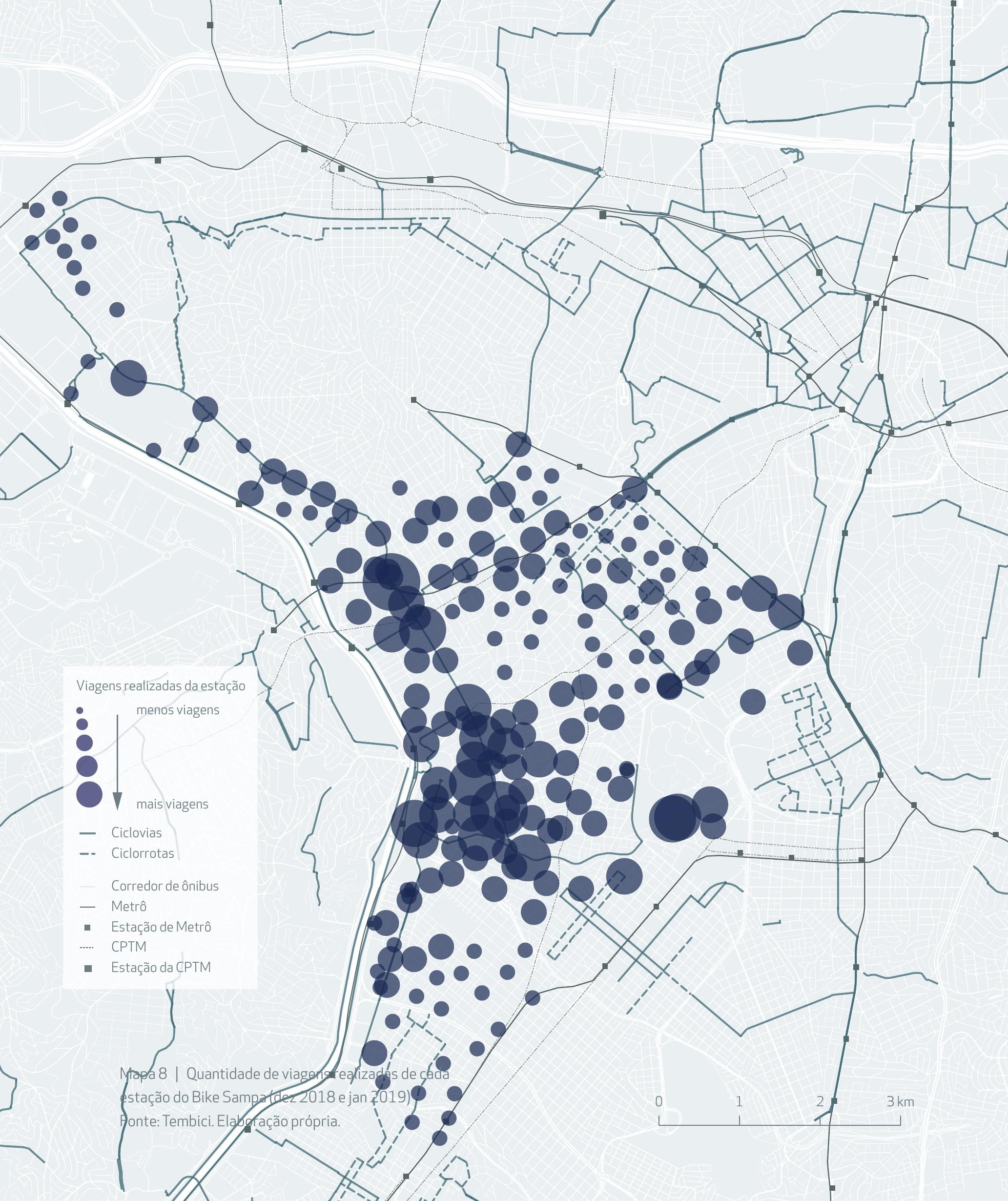




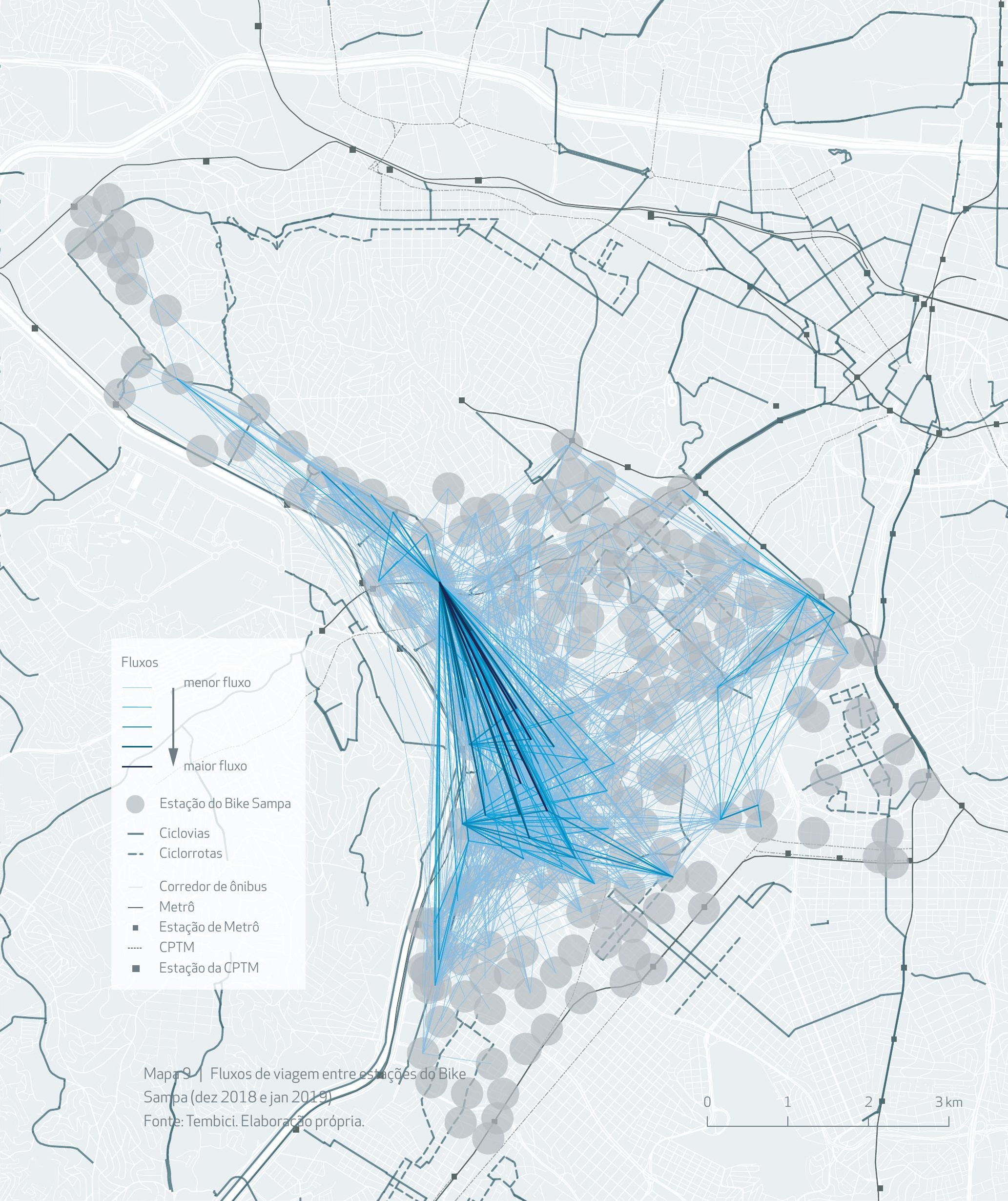


É interessante analisar os padrōes de viagem entre estaçôes e observar as mais utilizadas e os trajetos mais realizados. Esses dados podem auxiliar na elaboraçấo de políticas públicas em prol da bicicleta que avaliem as características do tecido urbano que mais influenciam o comportamento do usuário das bicicletas compartilhadas.

Nota-se o polo gerador de viagem concentrado na integraçăo modal do metrô Faria Lima, no Largo da Batata, e os trajetos mais utilizados para conectá-lo à regiâo da Vila Olímpia e Berrini, locais com grande volume de postos de trabalho. Esses trajetos sáo providos de infraestrutura cicloviária, o que consolida a bicicleta como meio de transporte no cotidiano.

Apesar do sistema concentrado no centro expandido, 76\% dos usuários residem fora da área de cobertura das estaçôes e utilizam o sistema na integraçâo com o transporte público como auxílio da última "perna" das viagens diárias. Essa condiçăo é comum nas outras cidades, como revelado na tabela 8.

\begin{tabular}{|c|c|}
\hline projeto & \% de usuários fora da área \\
\hline BikeRio & 68,2 \\
\hline BikePOA & 70,2 \\
\hline BikeSSA & 60,8 \\
\hline BikePE & 72,2 \\
\hline BikeSampa & 76,7 \\
\hline BikeVV & 58,1 \\
\hline
\end{tabular}

Tabela 8 | Porcentagem de usuários que moram fora da área de cobertura do SPBC Fonte: Tembici. 


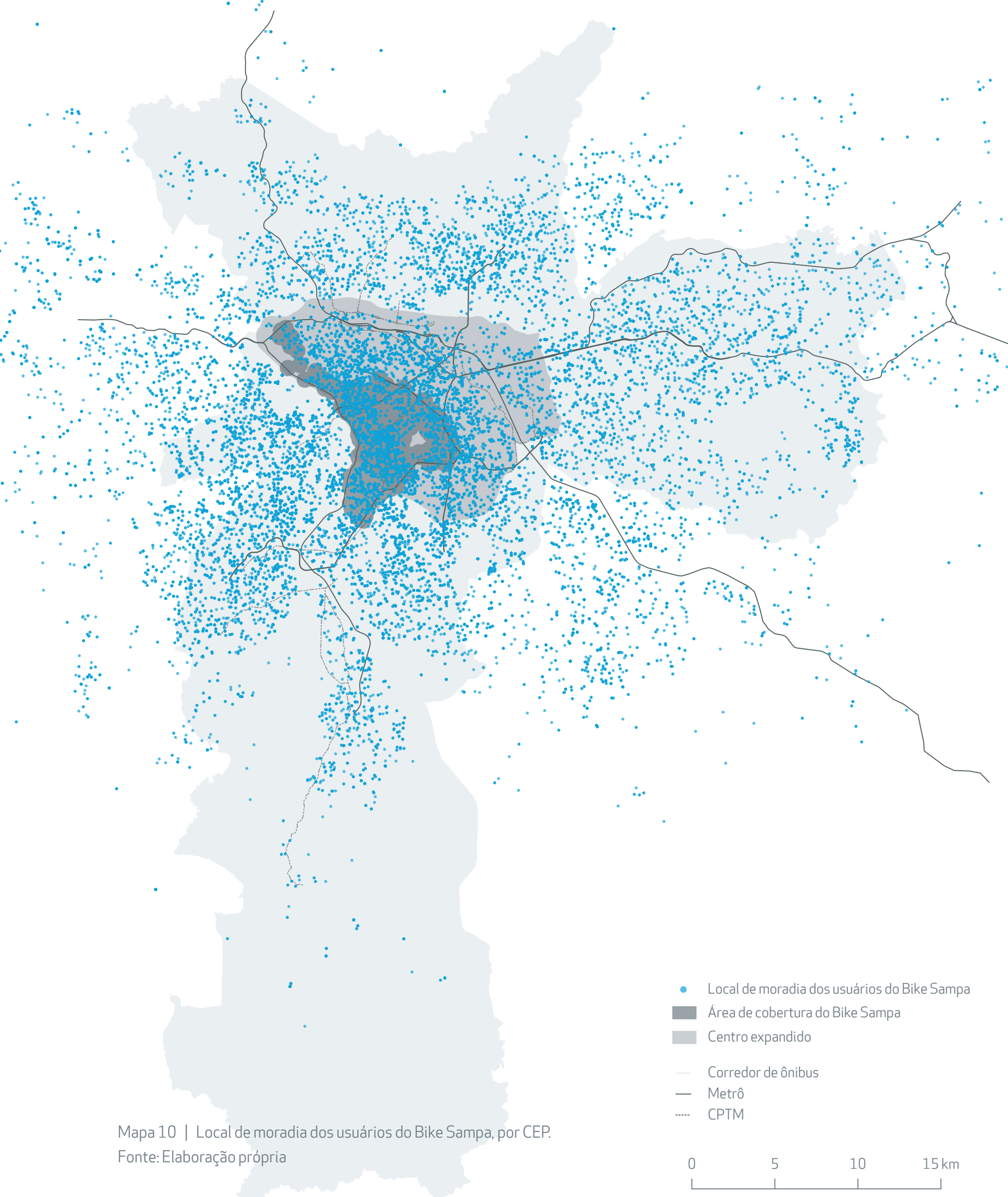


Desde o início do sistema Bike Sampa, contabilizaram-se nos gráficos 30, 31 e 32 mensalmente a quantidade de estaçôes, bicicletas e viagens e as variaçôes ao longo do tempo. Utilizaram-se a base de dados da Tembici e a da empresa operadora anterior (Serttel). Foram desconsideradas todas as viagens com menos de cinco minutos realizadas com retirada e devoluçăo na mesma estaçăo, pois apresentam alta probabilidade de caracterizarem-se como viagens inacabadas, devido à possíveis problemas mecânicos da bicicleta.

Os gráficos de Viagem por Dia e Viagem por Dia por Bicicleta (VDB) mostram que até 2018 o número máximo alcançado foi de 2.500 viagens e o índice variou entre uma e duas e meia viagens por dia por bicicleta, muito distante do indicado pelo ITDP (2014) para o sistema exitoso, que seria de quatro a oito.

Após o novo Bike Sampa, no decorrer da instalaçăo das estaçōes, a média de viagens chegou a cinco mil por dia em setembro de 2018 e 6.300 em janeiro de 2019, com o recorde de mais de 9 mil viagens em 29 de janeiro de 2019. Nesse mês, o sistema apresentou três viagens por dia por bicicleta (VDB), o maior índice da história do Bike Sampa. O resultado foi calculado com base na quantidade de bicicletas identificadas no sistema por mês. No entanto, ele ainda permanece abaixo da média considerada ideal pelo ITDP (2014). Acredito que isso aconteça pelo padrâo tăo marcante de uso da bicicleta para o trabalho, pelos picos de viagens bem demarcados no início e no final do dia, pelo vale de uso no período da tarde, com número muito baixo de viagens, e pela característica pendular unidirecional das viagens, entre a Estaçăo de Metrô Faria Lima e a regiăo da Vila Olímpia, com saída do metrô na parte da manhâ e retorno no final do dia. 
Essa característica faz com que os usuários tenham a tendência de lançar măo da bicicleta apenas duas vezes ao longo do dia. O uso em maior escala depende da operaçăo de redistribuiçăo que leva as bicicletas que já chegaram ao seu destino ao ponto de início, para que outras pessoas realizem o mesmo trajeto, e dessa forma aumente a quantidade de viagens por dia por cada bicicleta.

Com maior número de instalaçóes no fim do ano, a previsăo é de que esse índice cresça e haja maior diversificaçăo no uso das bicicletas ao longo do dia, pelo maior leque de possibilidades de origem e destino. A variaçăo do índice VDB deve-se principalmente à oscilaçâo do número de bicicletas ativas no sistema. Quando há acréscimo abrupto no número de bicicletas e novas estaçōes, o aumento de viagens náo costuma ser instantâneo. No início, o VDB diminui, para acentuado crescimento nos meses seguintes, o que demonstra a entrada de novos usuários que aos poucos começam a utilizar as bicicletas do sistema no cotidiano. 


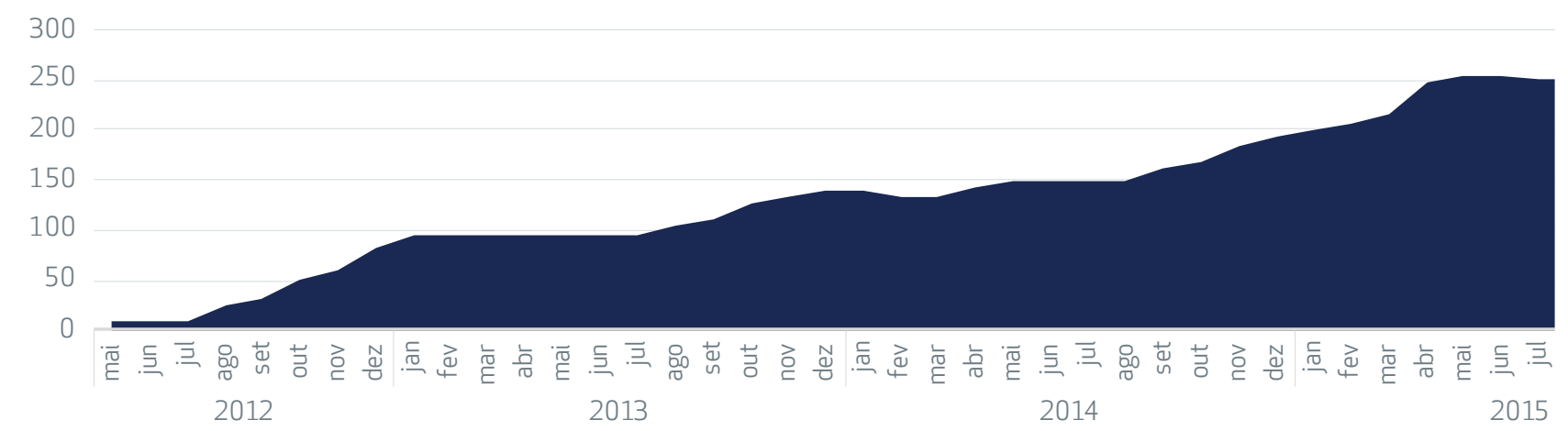

Gráfico 30 | Quantidades de estações por mês de 2012 a janeiro de 2019

Fonte: Tembici, elaboração própria.

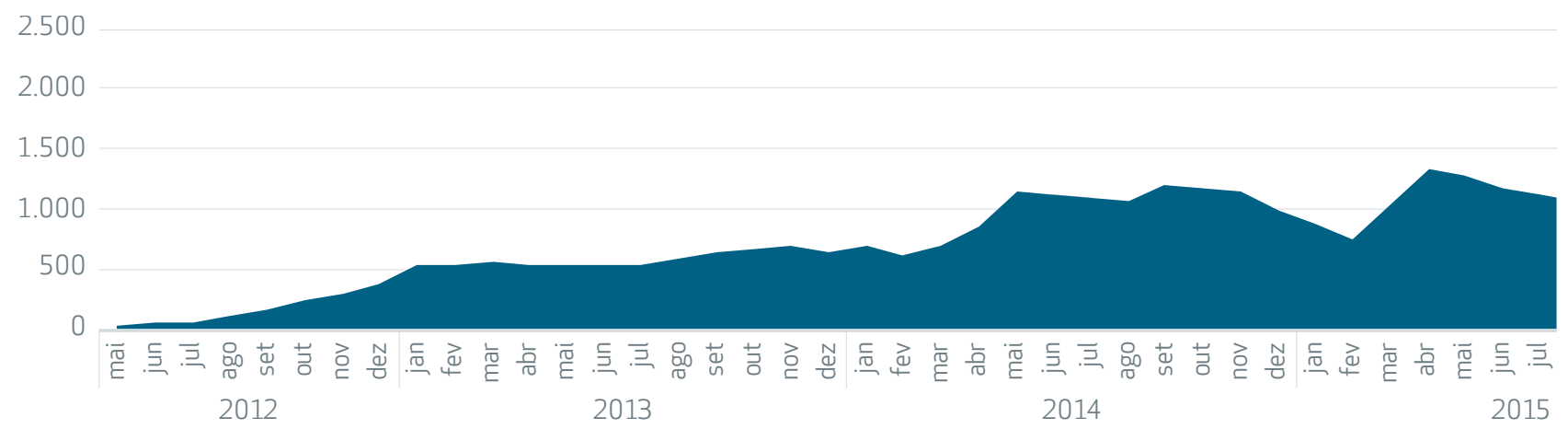

Gráfico 31 | Quantidade de bicicletas por mês de 2012 a janeiro de 2019

Fonte: Tembici, elaboração própria.

250.000

200.000

150.000

100.000

50.000

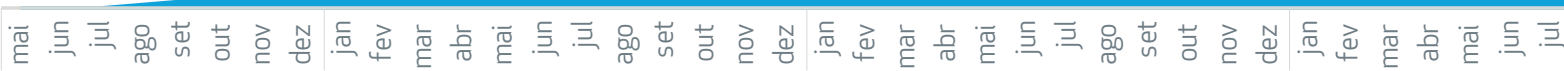
2012 2013 2014

Gráfico 32 | Quantidade de viagens por mês de 2012 a janeiro de 2019

Fonte: Tembici, elaboração própria 


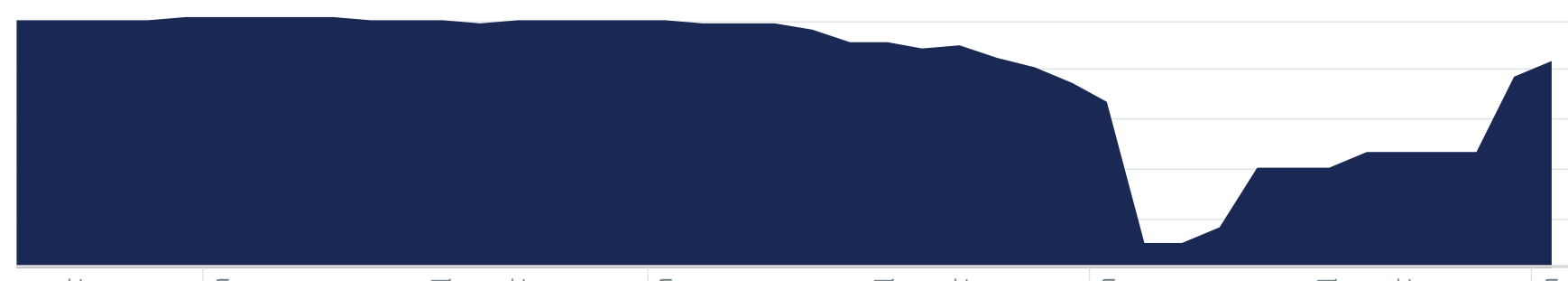

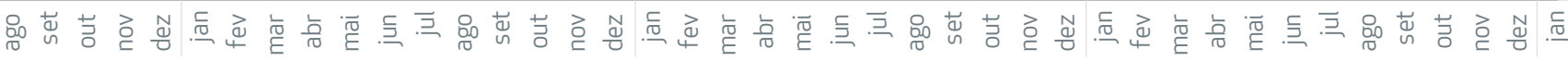
2016 2017

2018

2019

estações

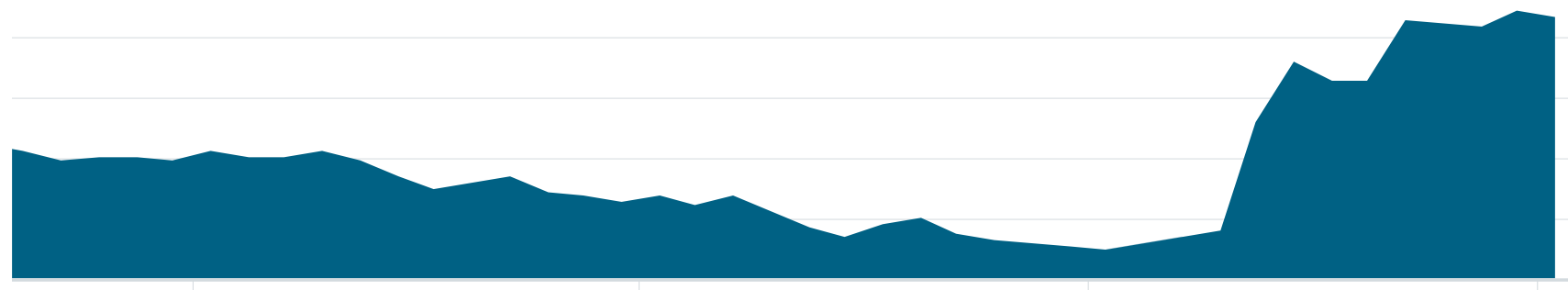

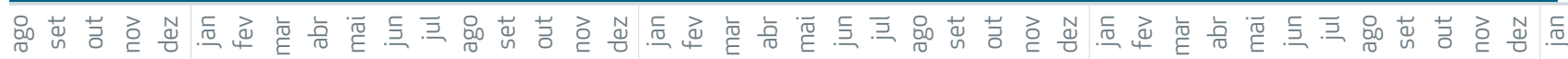
2016 2017

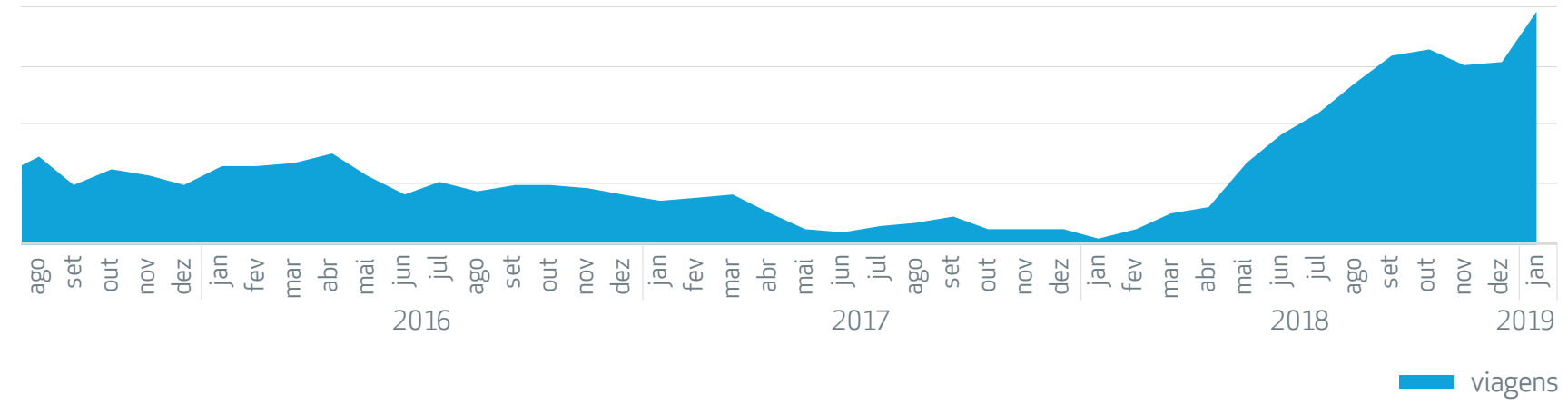




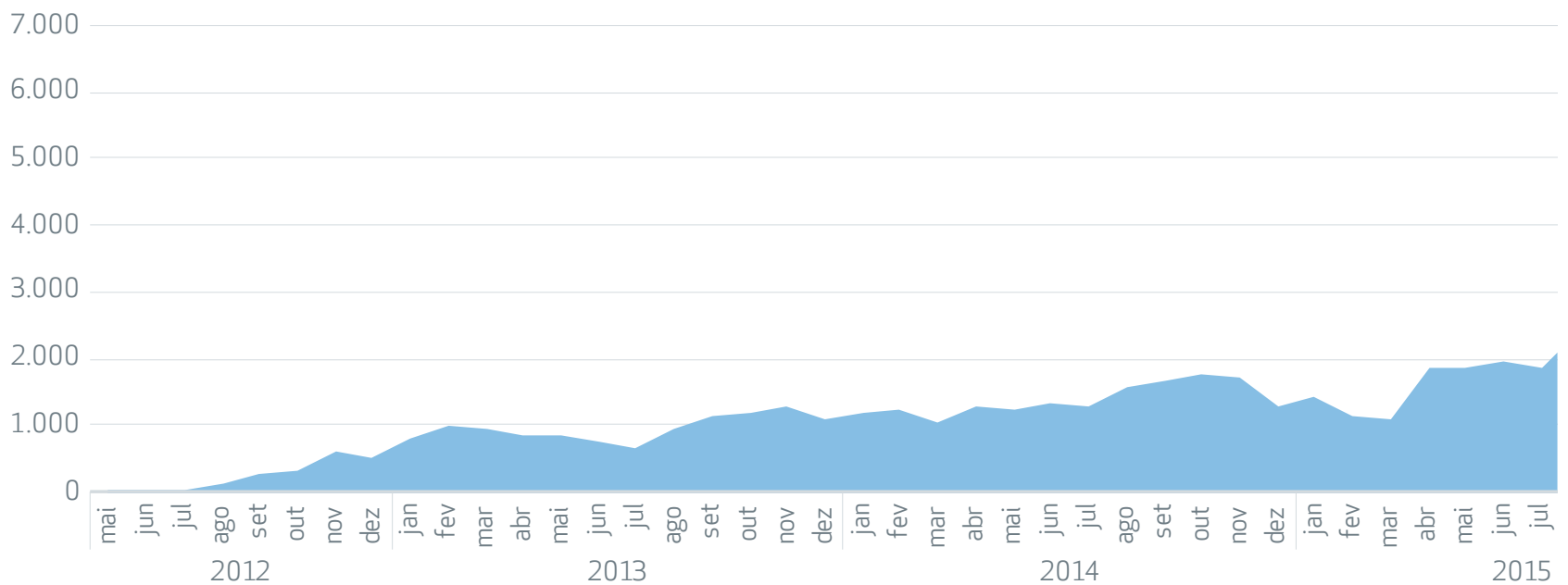

Gráfico 33 | Quantidade de viagens por dia em cada mês de 2012 a janeiro de 2019

Fonte: Tembici, elaboração própria.

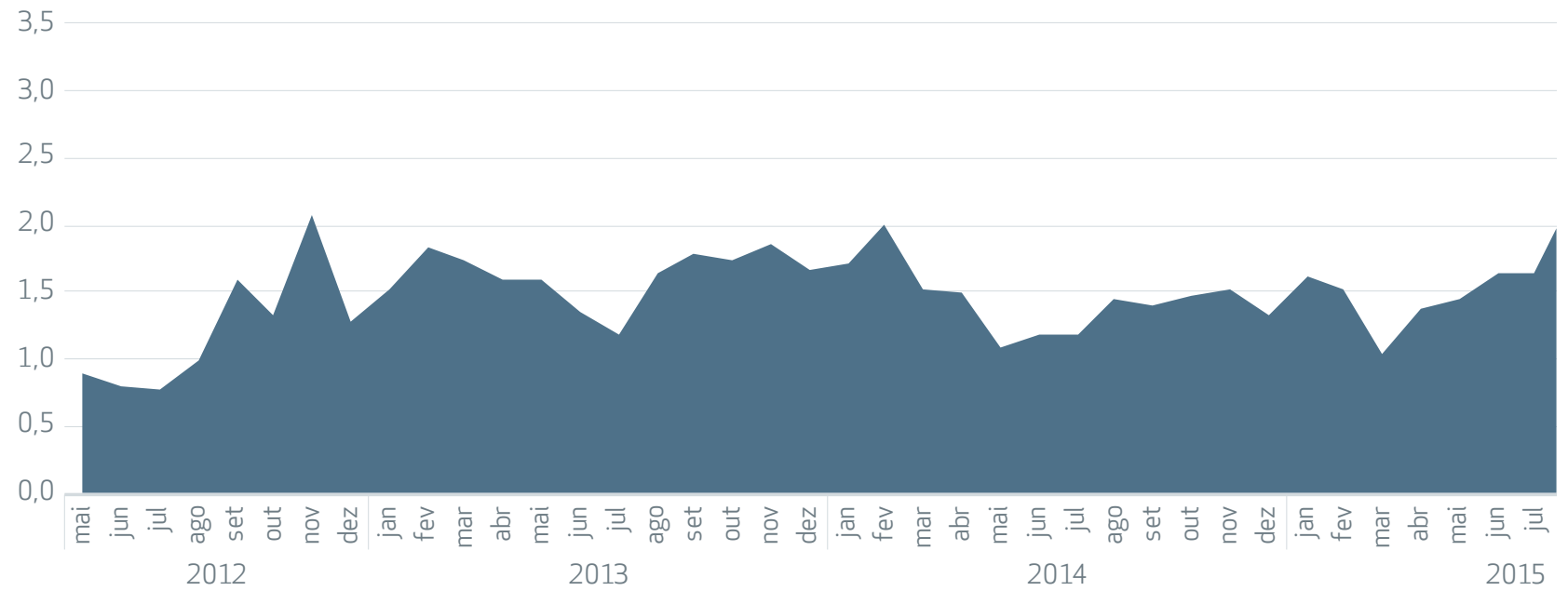

Gráfico 34 | Quantidade de viagens por dia por bicicleta em cada mês de 2012 a janeiro de 2019

Fonte: Tembici, elaboração própria. 


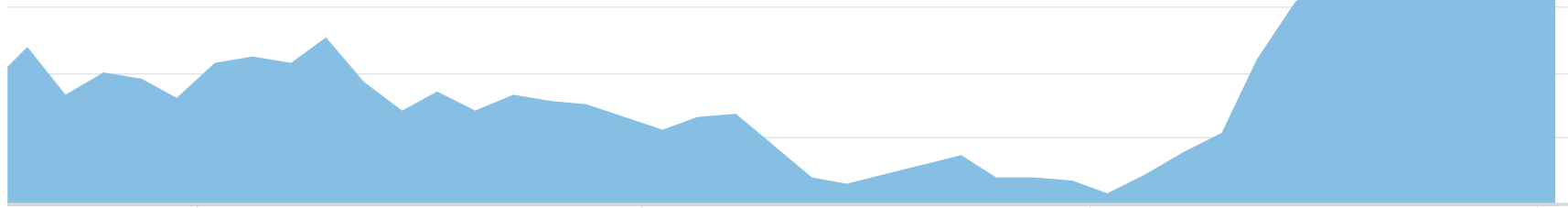

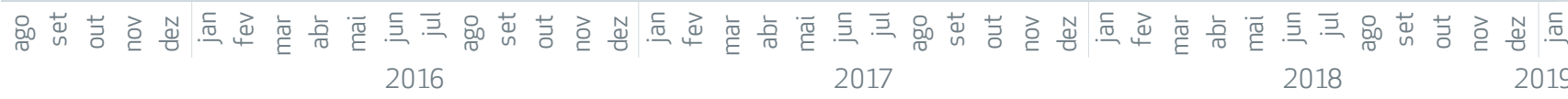
viagens por dia

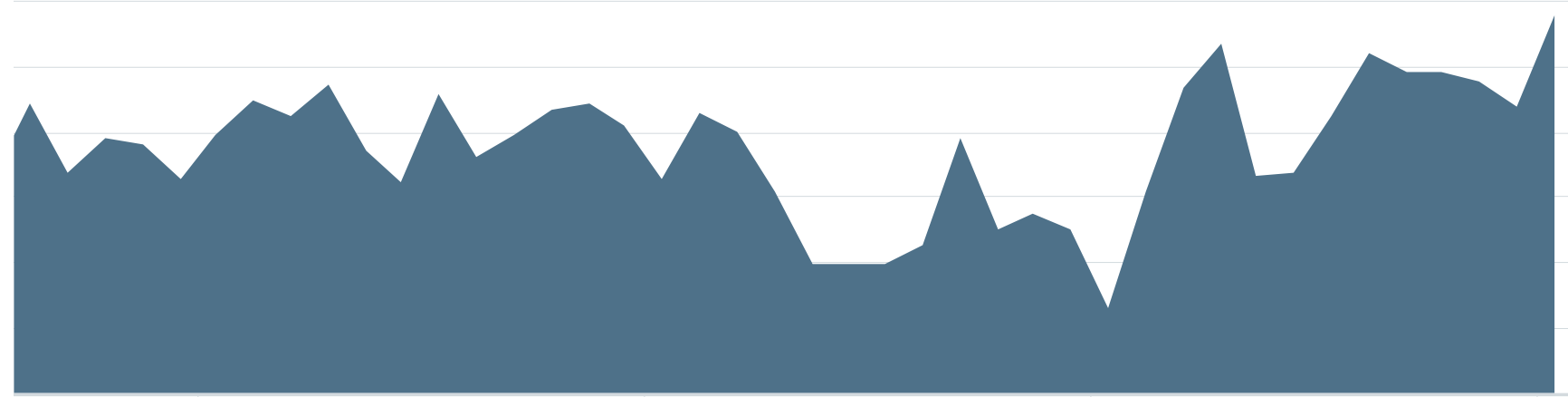

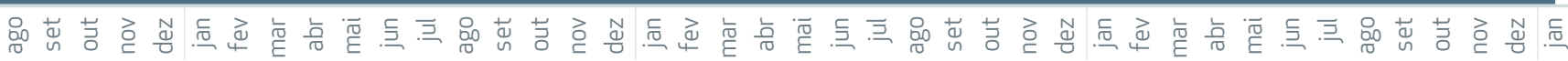
2016 2017 
O gráfico 35 compara a quantidade média de viagens por dia em cada mês, considerando dias de semana e fins de semana. Até 2018, năo havia muita diferenciaçăo no uso de dia de semana e de final de semana, o que pode caracterizar a utilizaçâo esporádica e de lazer com picos visíveis em alguns fins de semana. Após a implantaçăo do novo sistema, houve crescimento exponencial na quantidade de viagens durante a semana - o que revela a adesăo ao uso diário para trabalho e estudo -, muito maior do que as viagens de lazer que ocorrem aos sábados, domingos e feriados.

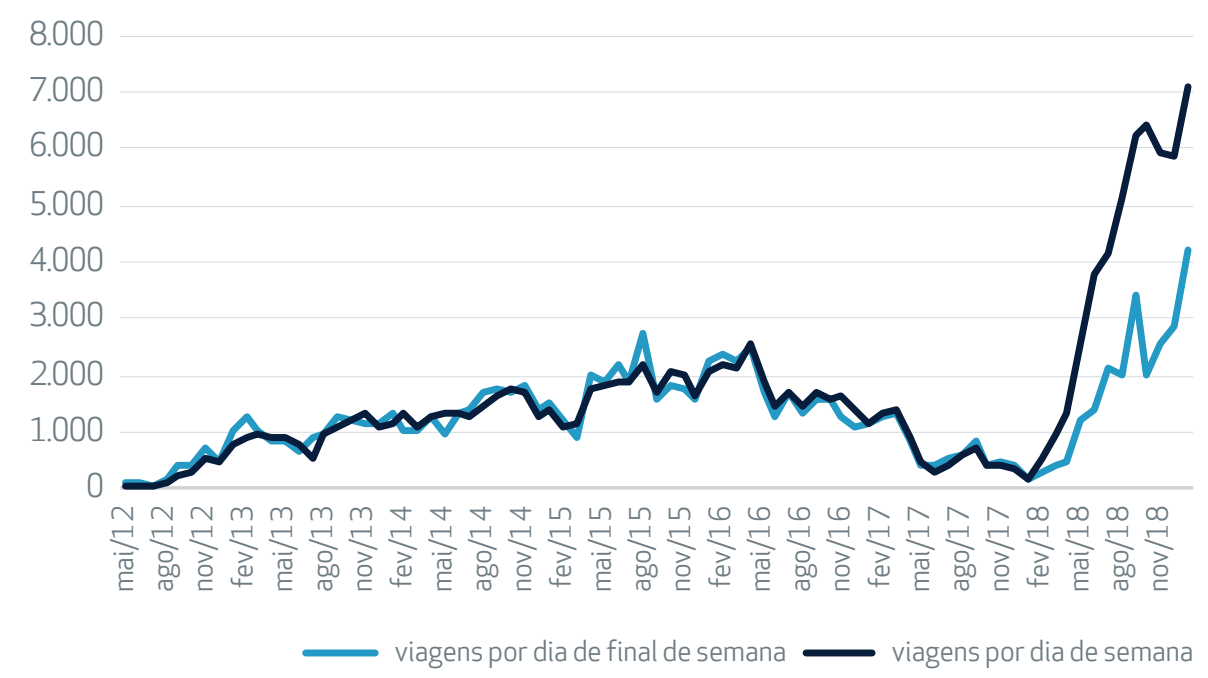

Gráfico 35 | Viagens por dia de semana e por dia de final de semana no Bike Sampa Fonte: Tembici. Elaboração própria.

Nos gráficos seguintes, percebe-se a evoluçâo ao longo do tempo da proporçấo de viagens realizadas para a mesma estaçâo e viagens com até sessenta minutos, o que indica o aumento do uso das bicicletas compartilhadas para deslocamentos curtos, pela confiabilidade e eficiência do novo sistema. 


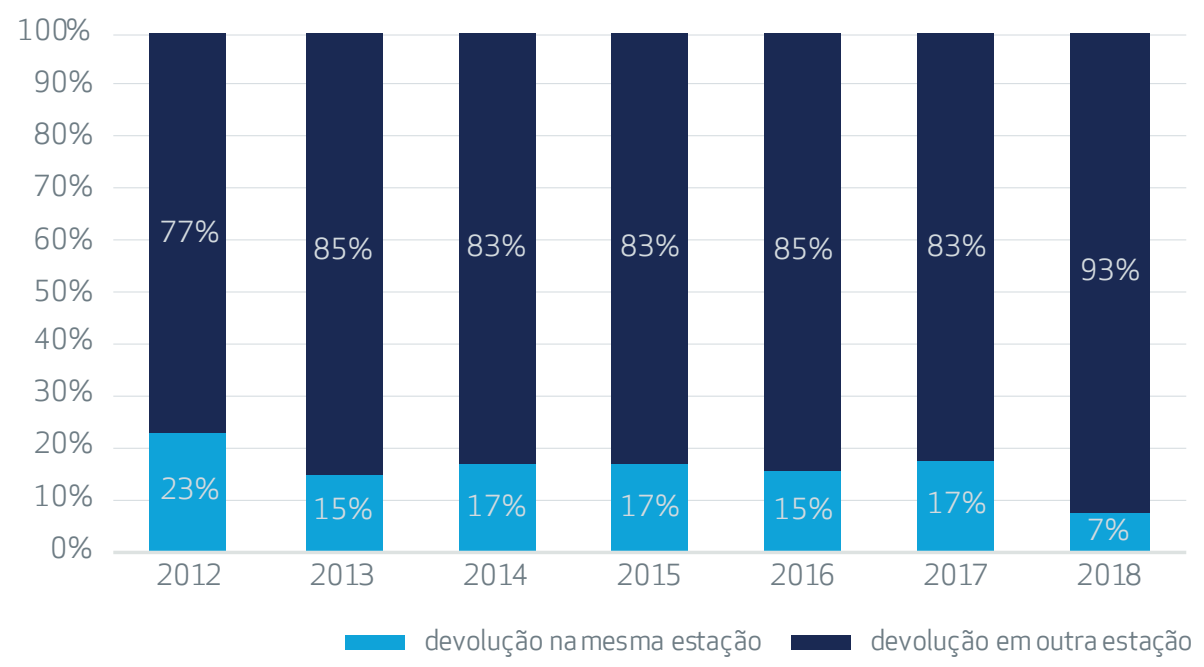

Gráfico 36 | Viagens com devolução na mesma estação ou em estações diferentes Fonte: Tembici. Elaboração própria.

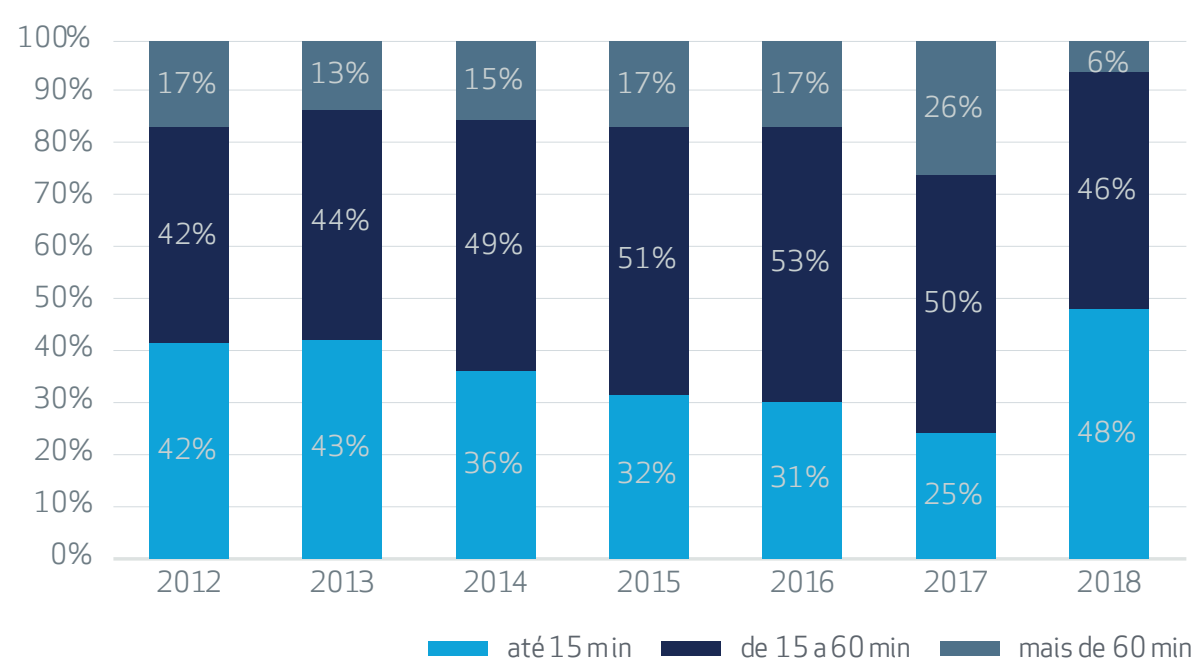

Gráfico 37 | Duração das viagens totais do Bike Sampa

Fonte: Tembici. Elaboração própria. 


\subsection{Exemplo: Cidade do México - Ecobici}

Em 2010, iniciou-se o sistema Ecobici, sistema público de compartilhamento de bicicletas da Cidade do México, com 85 estaçôes e 1.114 bicicletas disponíveis. Em 2012, houve a ampliaçăo das fases II e III com 170 estaçóes, somando no total 260 estaçôes. Em 2013, foi implantada a integraçâo do sistema Ecobici com o cartăo de transporte, o que fomentou a intermodalidade com metrô, ônibus e transportes elétricos. Em 2015, houve nova ampliaçăo com mais 170 estaçóes, ultrapassando 400 estaçóes na cidade e 5 mil bicicletas disponíveis no sistema. 


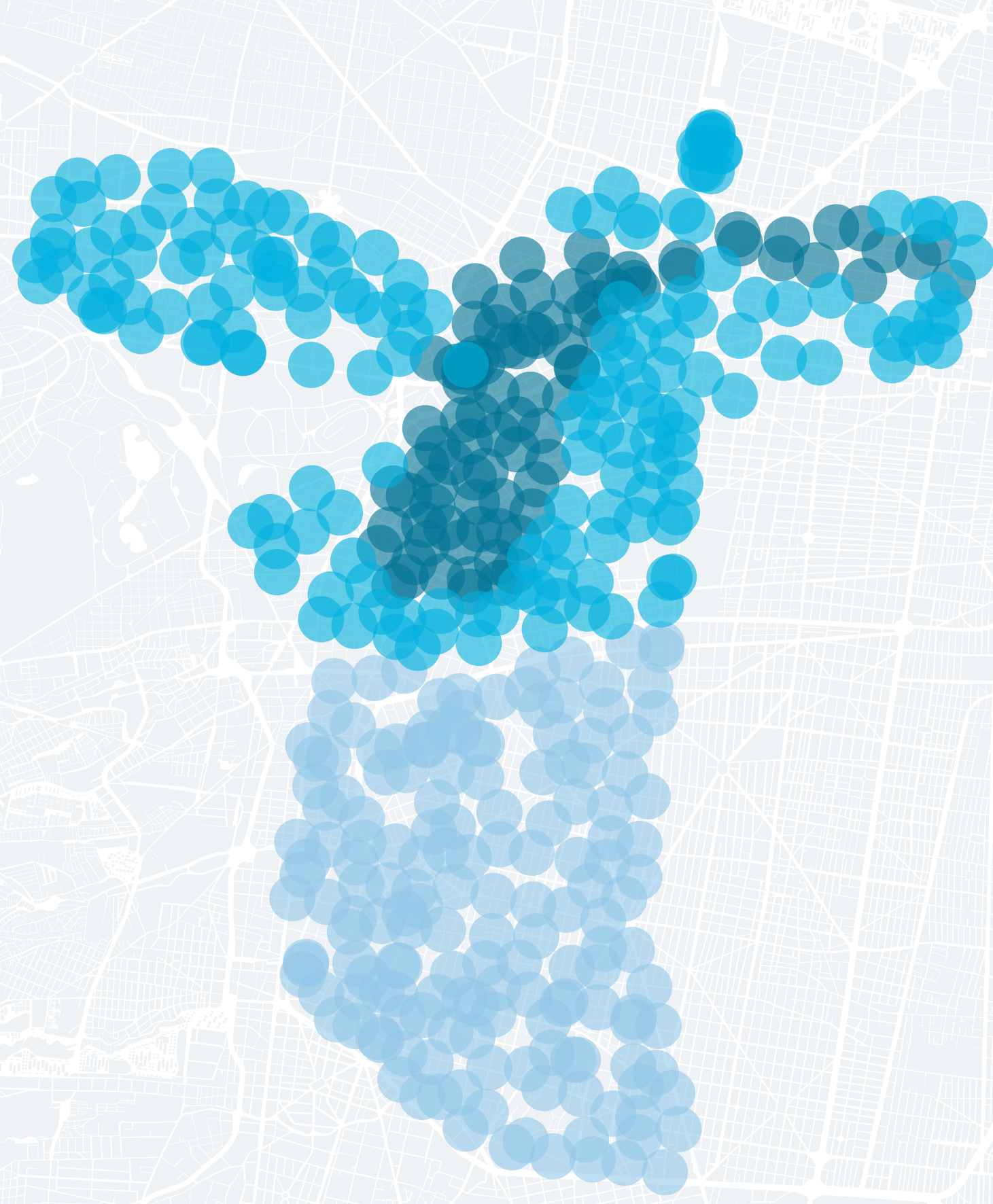

Estações do Ecobici

Mapa 11 | Sistema Ecobici, Cidade do México, com faseamento das instalações

Fasel

Fases II e III

Fonte: Ecobici. Elaboração própria.

\begin{tabular}{lllll}
0 & 1 & 2 & $3 \mathrm{~km}$ \\
\hline
\end{tabular}




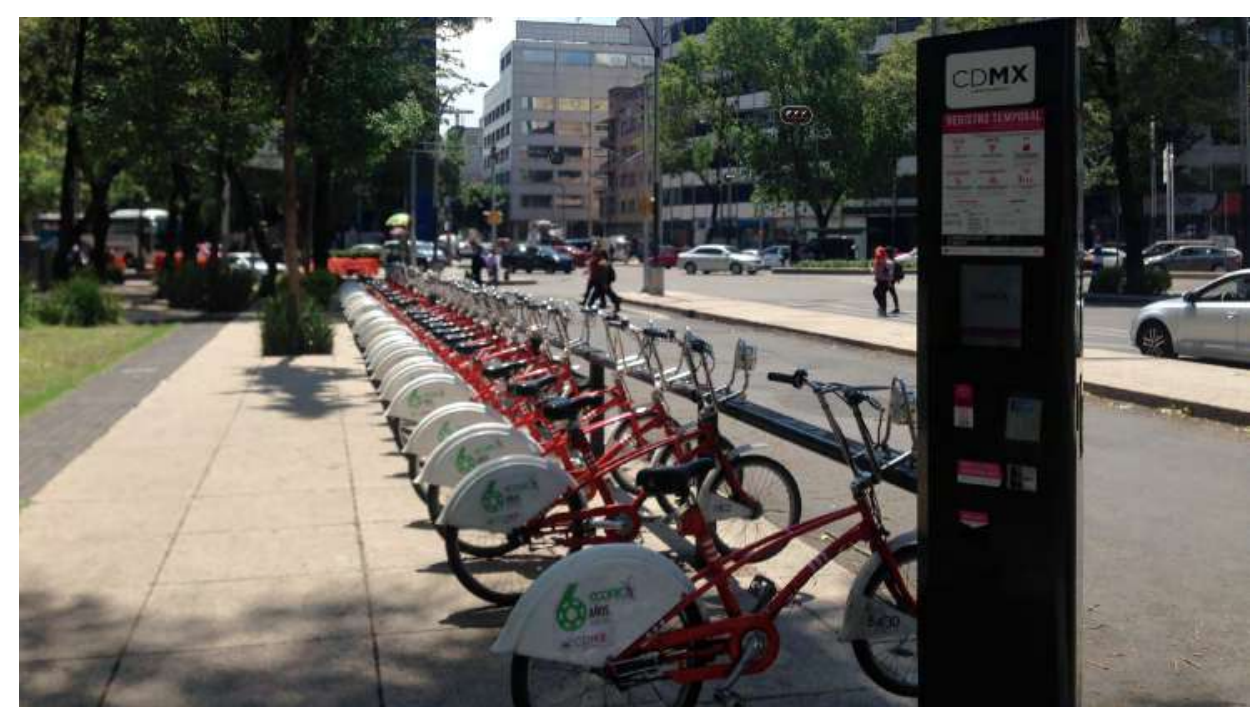

Foto 39 | Sistema Ecobici na Cidade do México Fonte: acervo pessoal (2017).

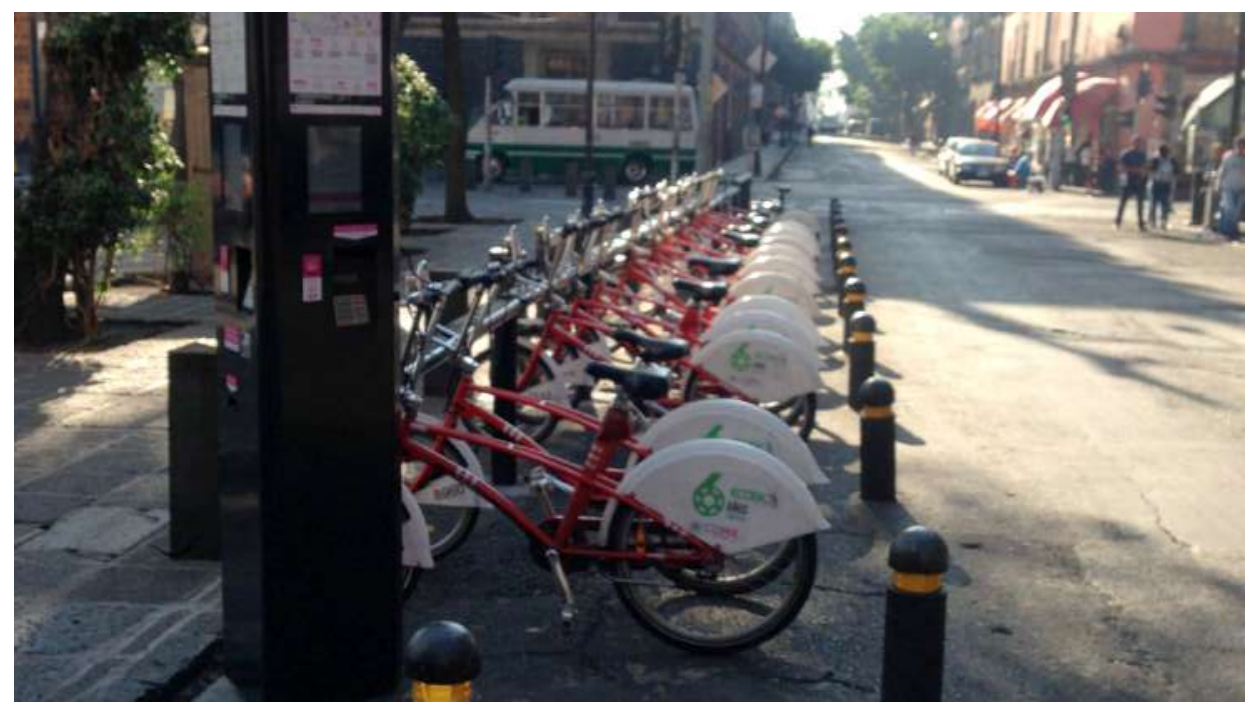

Foto 40 | Sistema Ecobici na Cidade do México Fonte: acervo pessoal (2017). 


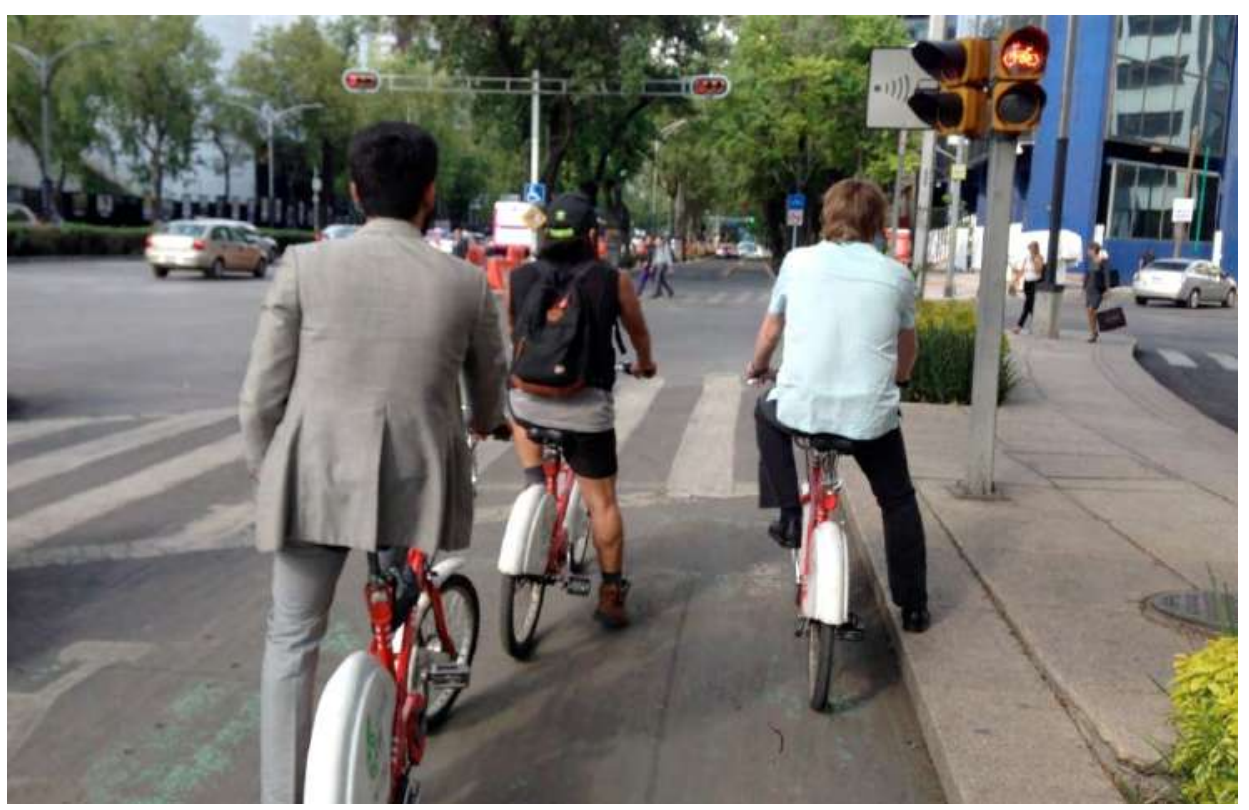

Foto 41 | Usuários do sistema Ecobici na Cidade do México

Fonte: acervo pessoal (2017).

Em abril de 2017, participei do Foro Mundial da Bicicleta na Cidade do México, e conheci o SPBC da cidade. O sistema se destaca por sua densidade de onze estaçôes por quilômetro quadrado ${ }^{25}$ e pelo elevado uso diário. As estaçôes possuem dimensionamento diferente, de acordo com a demanda, e ocupam-se extensas áreas, tanto nas largas calçadas, sem atrapalhar o espaço do pedestre, quanto no leito carroçável, mostradas nas fotos 39 e 40.

Foi realizada pesquisa com os usuários para análise do perfil (sexo, idade, estado civil, grau de escolaridade, profissăo), ano de inscriçăo no Ecobici e bairro de residência, e para coleta de informaçôes a respeito do propósito e destino da viagem, frequência, intermodalidade, duraçăo (total e de bicicleta

25 Que representa distância média entre estações de 190 metros. 
do Ecobici). Perguntas sobre a mudança da qualidade de vida com o uso do sistema, por onde circula e onde gostaria de circular, sobre as grandes dificuldades de movimentaçăo em bicicleta pela cidade também estâo presentes. Os dados sâo apresentados em seguida.

A maioria dos respondentes (59\%) nâo utilizava a bicicleta como meio de transporte, o que caracteriza o SPBC como experimentaçăo importante para incentivar o ciclismo urbano. Segundo a pesquisa, 60\% das pessoas conheceram o Ecobici na cidade, e isso comprova a importância da localizaçâo visível das estaçôes, como próximas às esquinas, nas saídas do transporte público, e perto da infraestrutura cicloviária. Dos entrevistados, $87 \%$ combinam as viagens em bicicleta compartilhada com outros meios de transporte.

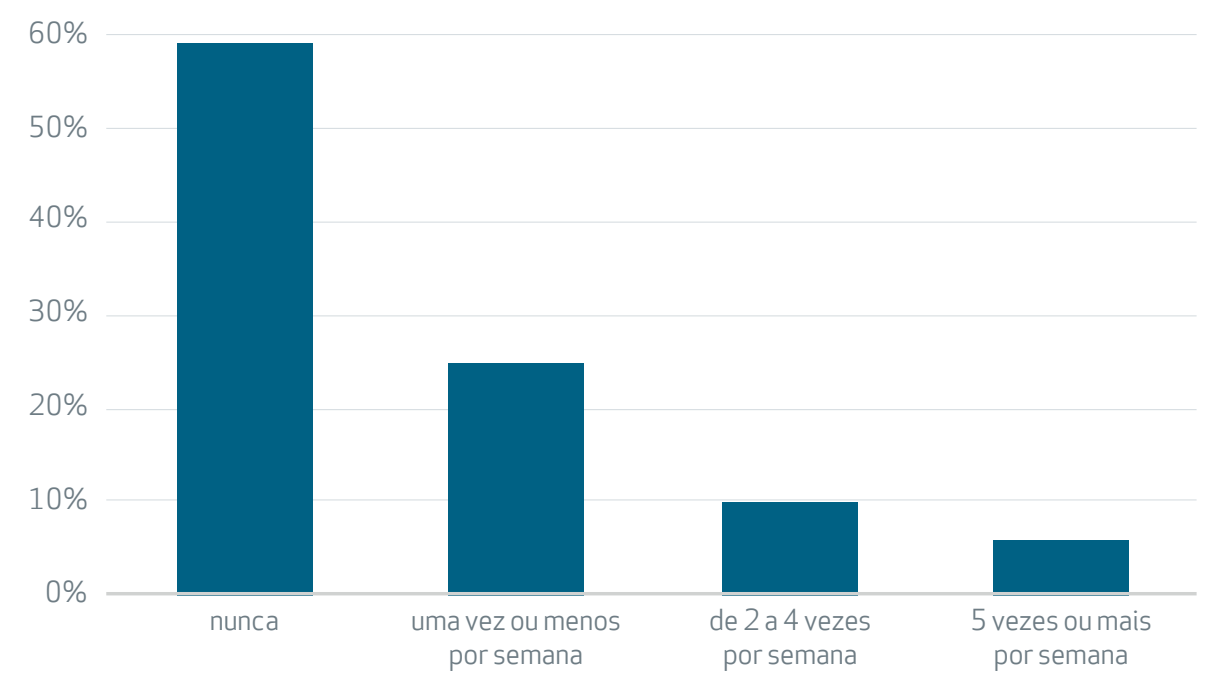

Gráfico 38 | Pesquisa com usuários do Ecobici em 2014: antes de utilizar o ECOBICl, usava a bicicleta como meio de transporte? Com que frequência?

Fonte: CDMX (2014). 


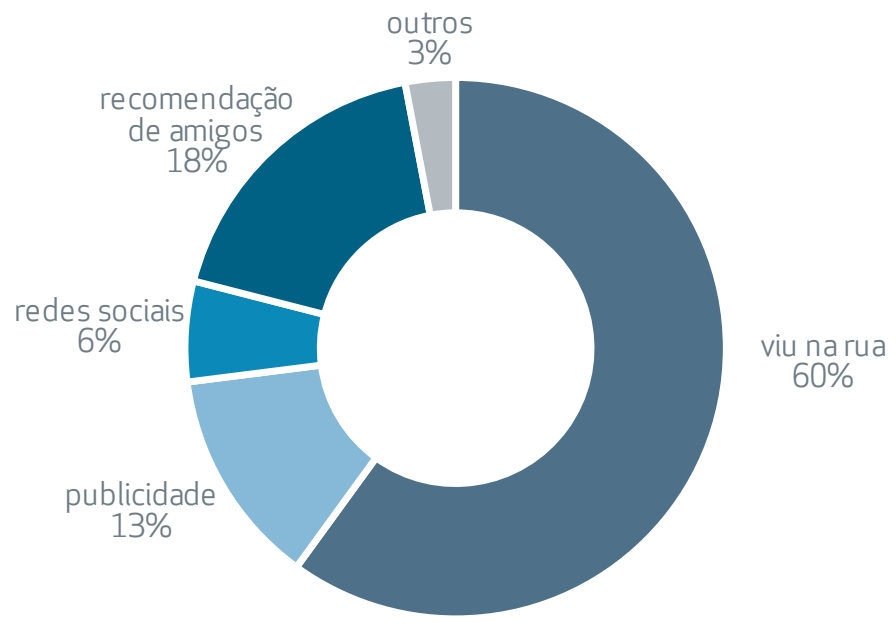

Gráfico 39 | Pesquisa com usuários do Ecobici em 2014: como descobriu o ECOBICI? Fonte: CDMX (2014).

\section{$13 \%$ das viagens se realizam \\ 010 somente com Ecobici}

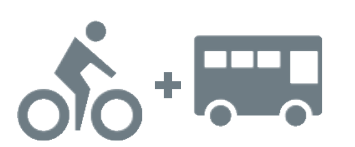

$\mathbf{8 7 \%}$ das viagens se realizam combinando com outros modos de transporte

Gráfico 40 | Pesquisa com usuários do Ecobici em 2014: integração modal Fonte: CDMX (2014). 


\subsubsection{Comparação Bike Sampa e Ecobici}

O mapa 12 mostra a comparaçăo da cidade de Săo Paulo e Cidade do México na mesma escala. A aproximaçăo representa as estaçôes com circunferência de raio de influência de 200 metros. O sistema da Cidade do México é reconhecido como projeto de sucesso, com mais de 25 mil viagens diárias e VDB próximo de seis. Percebe-se a diferença da densidade dos sistemas Ecobici e Bike Sampa (até 2017). 0 primeiro com mais de 400 estaçôes, enquanto São Paulo conta com 260, e ocupa área maior da cidade. Os gráficos a seguir apresentam o resultado do número de viagens devido ao planejamento do sistema.

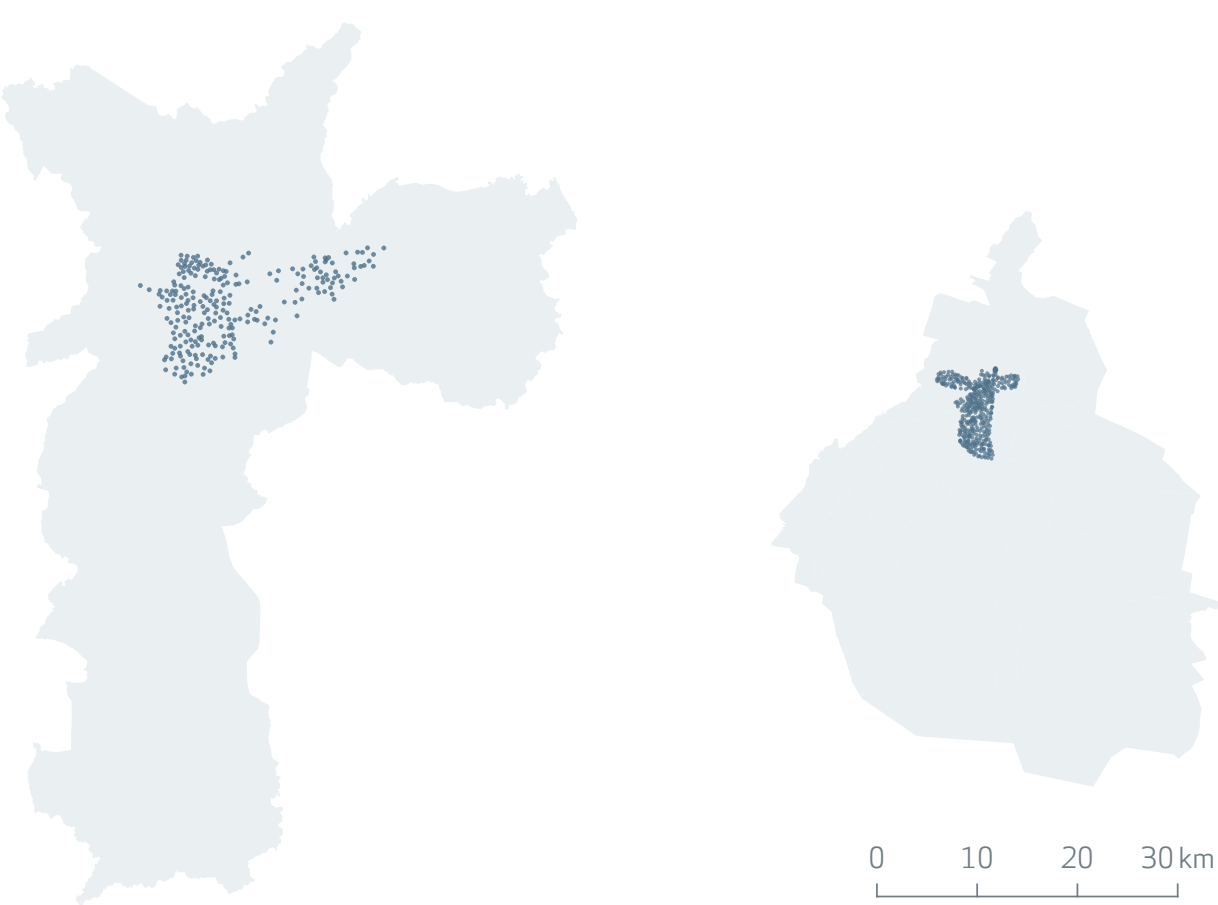

Mapa 12 | Cidade de São Paulo e Cidade do México com os respectivos SPBC

Fonte: Elaboração própria. 

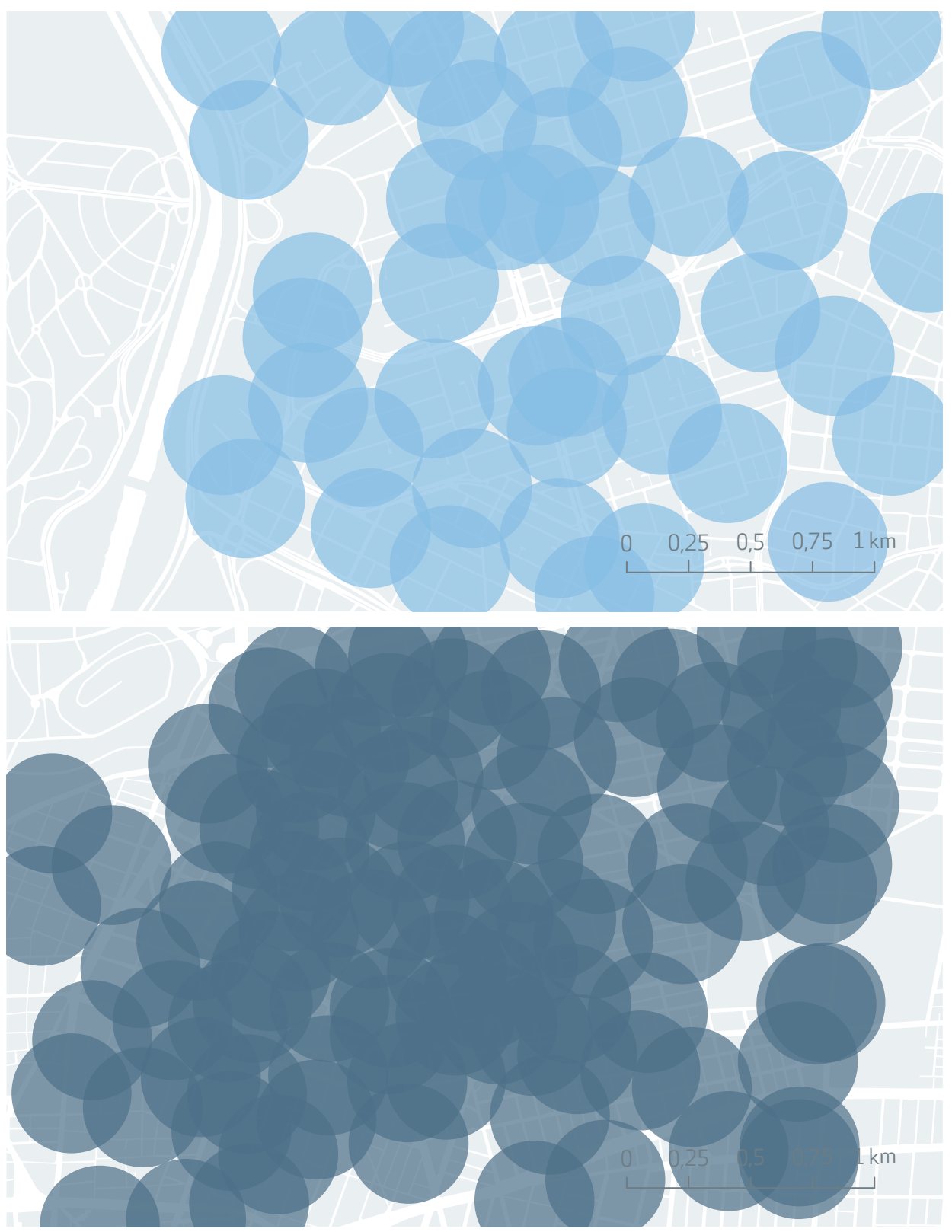

Mapa 13 | Cidade de São Paulo até janeiro de 2018 e Cidade do México com os respectivos SPBC. Circunferência com 200 metros de raio

Fonte: Elaboração própria. 


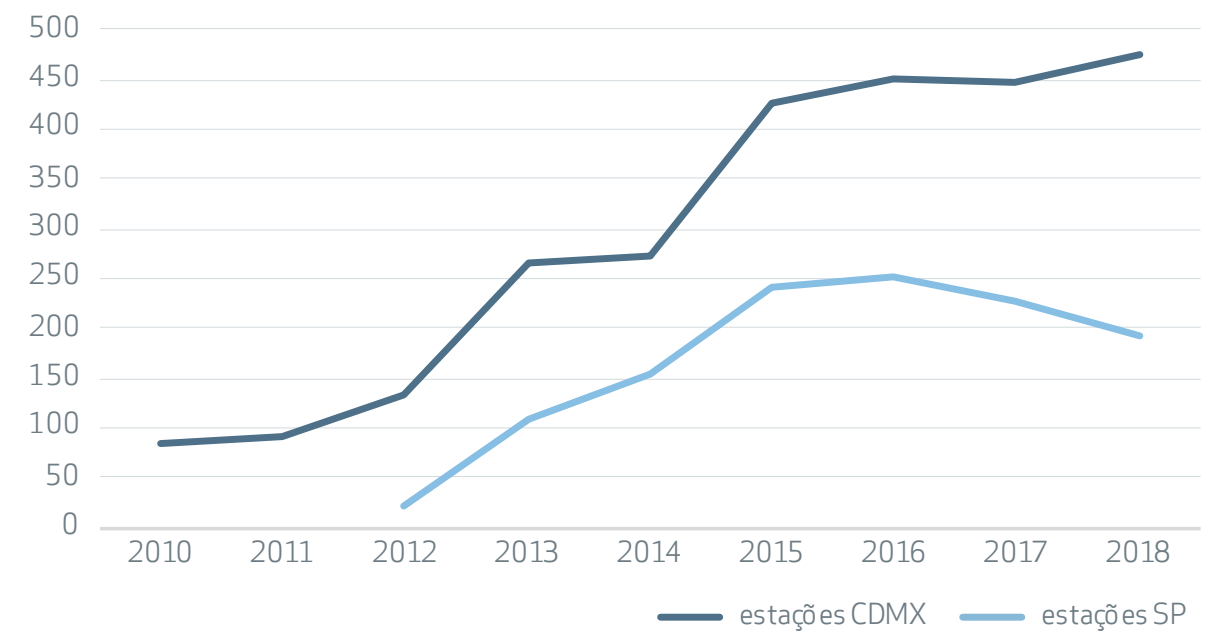

Gráfico 41 | Comparação da quantidade de estações do Bike Sampa e Ecobici desde a inauguração até o fim de 2018

Fontes: Tembici e Ecobici. Elaboração própria.

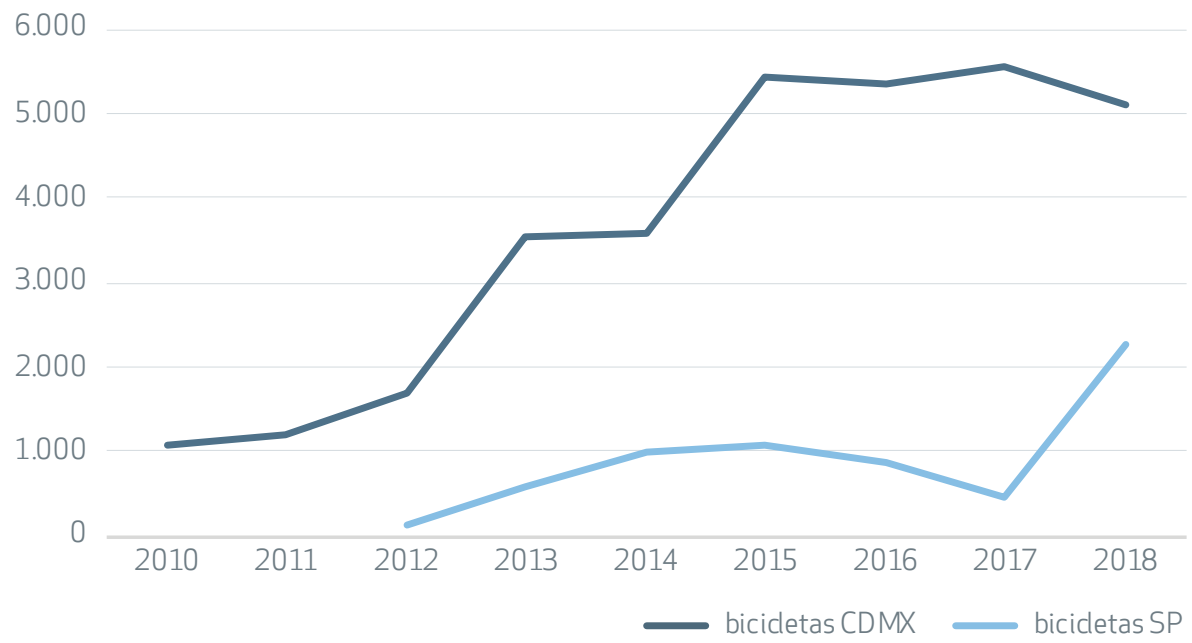

Gráfico 42 | Comparação da quantidade de bicicletas do Bike Sampa e Ecobici desde a inauguração até o fim de 2018

Fontes: Tembici e Ecobici. Elaboração própria. 


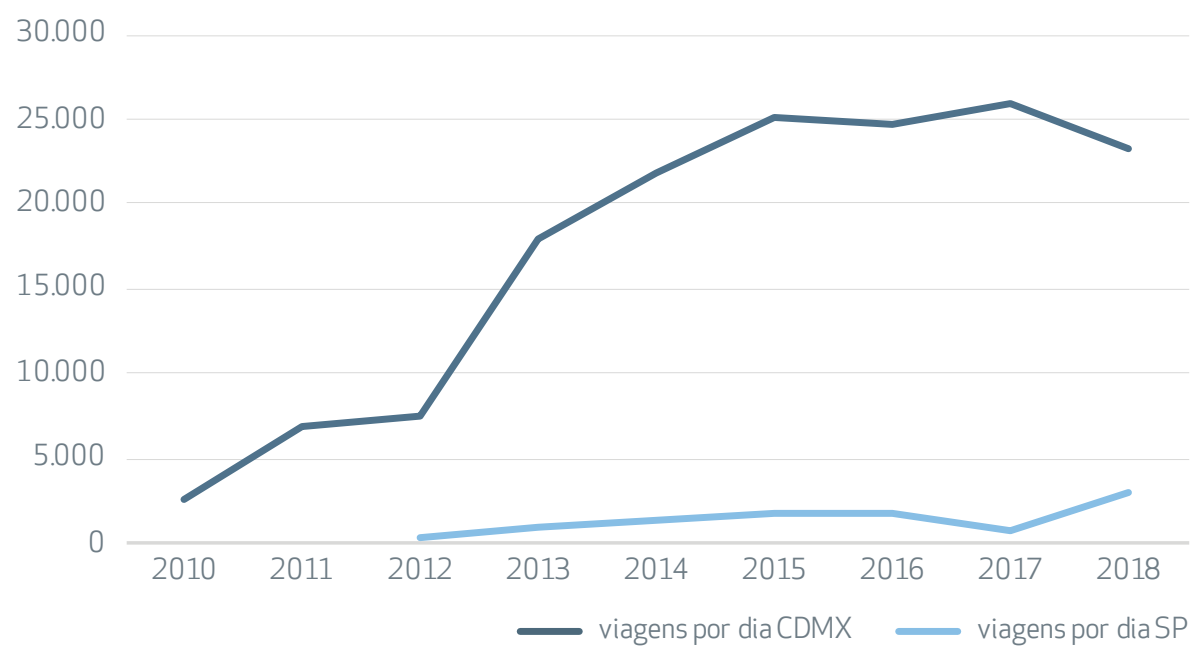

Gráfico 43 | Comparação da quantidade de viagens por ano do Bike Sampa e Ecobici desde a inauguração até o fim de 2018

Fontes: Tembici e Ecobici. Elaboração própria.

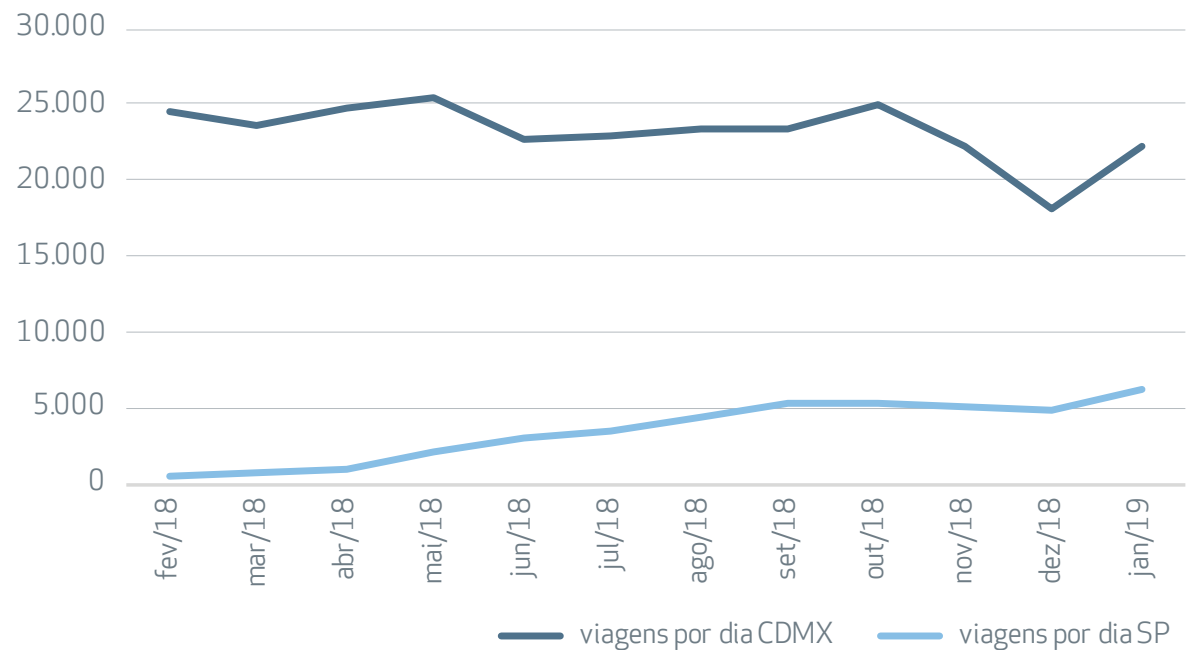

Gráfico 44 | Comparação da quantidade de viagens por dia do Bike Sampa e do Ecobici nos últimos doze meses

Fontes: Tembici e Ecobici. Elaboração própria. 


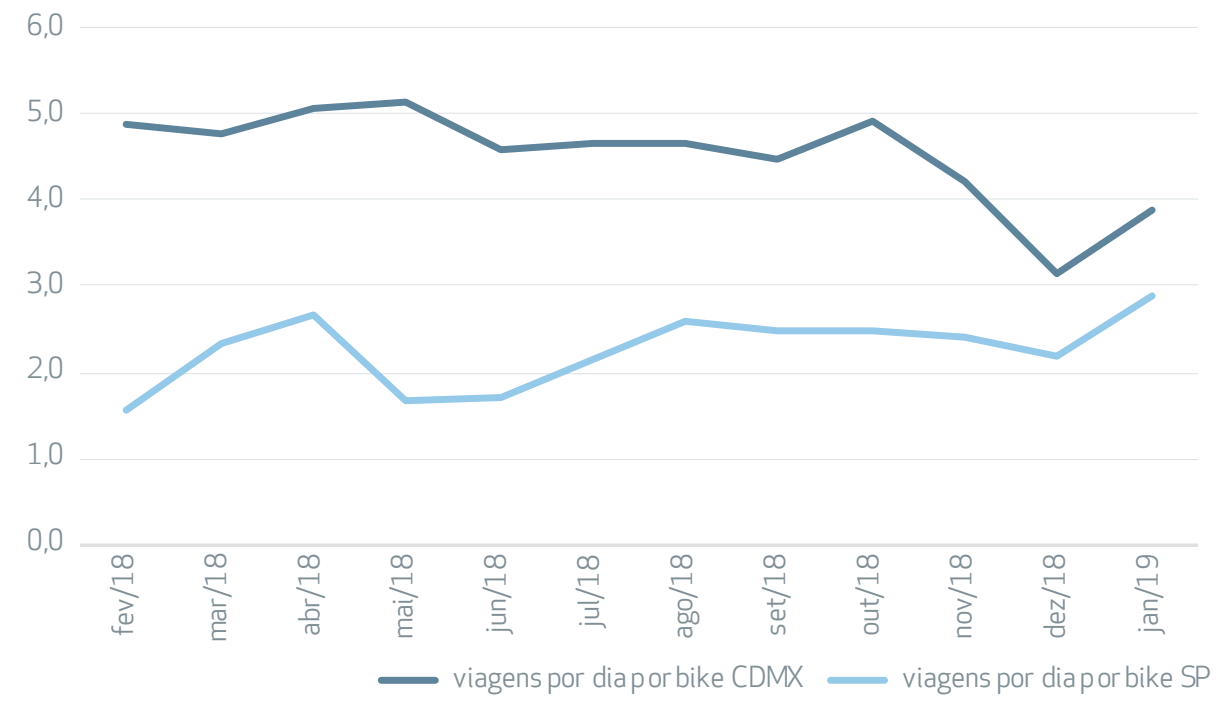

Gráfico 45 | Comparação das viagens por dia por bicicleta do Bike Sampa e do Ecobici dos últimos doze meses

Fontes: Tembici e Ecobici. Elaboração própria.

A seguir se encontram gráficos que apresentamos dados do sistema Ecobici ao longo dos anos. As informaçôes foram extraídas da base de dados abertos disponíveis no site https://www.ecobici.cdmx.gob.mx/es/informacion-delservicio/open-data (acesso em janeiro de 2019). No Ecobici, 97\% das pessoas devolvem a bicicleta em estaçâo diferente daquela em que houve a retirada, dado que sugere o uso voltado para o transporte e náo apenas para o lazer, e 99\% das viagens duram até 45 minutos (período sem cobrança adicional). 

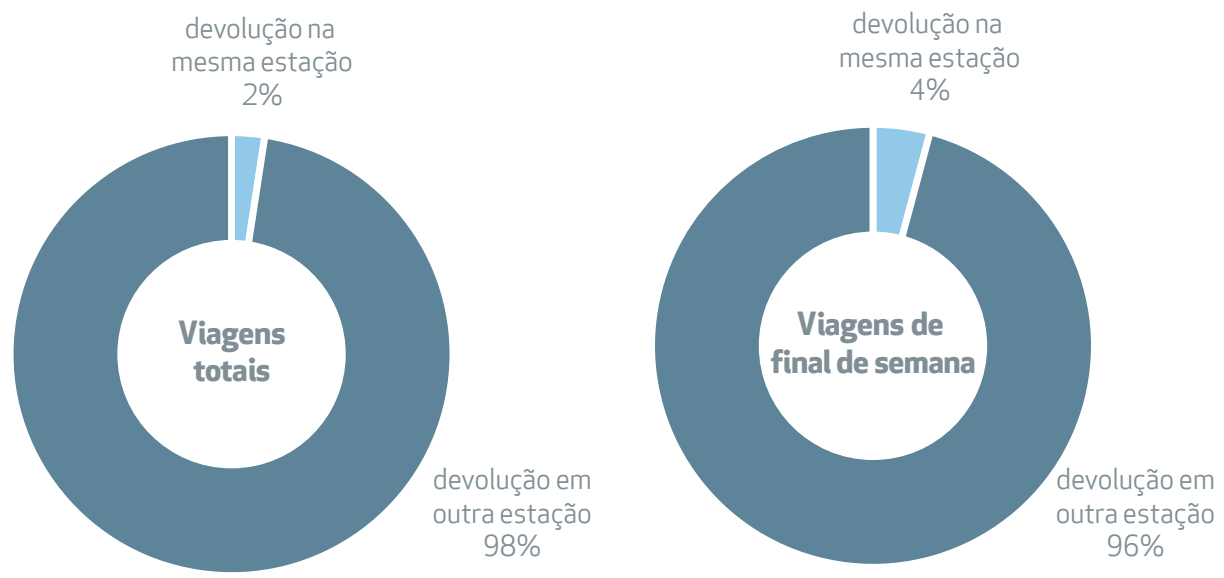

Gráfico 46 | Viagens totais e nos fins de semana realizadas com devolução na mesma estação ou em estaç̃̃es distintas de janeiro de 2018 a janeiro de 2019, no Ecobici Fonte: Ecobici. Elaboração própria.
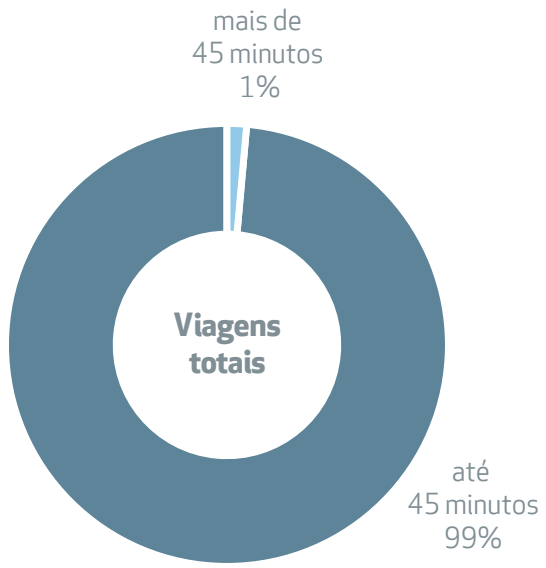

mais de 45 minutos $3 \%$

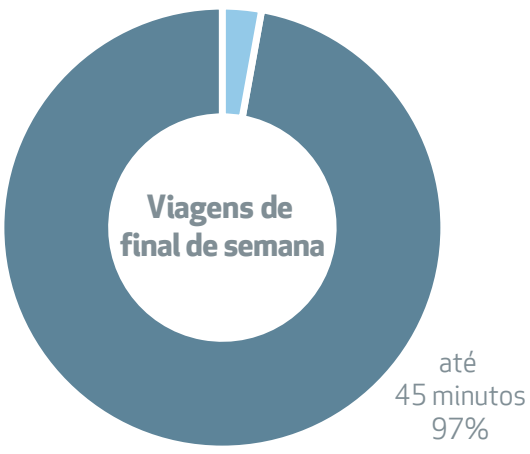

Gráfico 47 | Viagens totais e nos fins de semana realizadas por até 45 minutos ${ }^{26}$ de janeiro de 2018 a janeiro de 2019, no Ecobici

Fonte: Ecobici. Elaboração própria.

26 No Ecobici, não há cobrança adicional até 45 minutos de duração da viagem. 
Nos gráficos seguintes identificam-se algumas características das viagens do Bike Sampa. A retirada e a devoluçâo em estaçôes distintas acontecem em $93 \%$ das viagens totais e $94 \%$ săo realizadas em até sessenta minutos, o que indica possivelmente que săo feitas para transporte. No fim de semana, o índice de retiradas e devoluçôes na mesma estaçâo passa de 7\% para 27\%, e a quantidade de viagens com mais de sessenta minutos, de $6 \%$ para $25 \%$, o que denota maior ênfase para o lazer. O CEBRAP avalia que retiradas e devoluçóes na mesma estaçăo e duraçăo de uso maior que sessenta minutos indicam com maior probabilidade o lazer como finalidade.
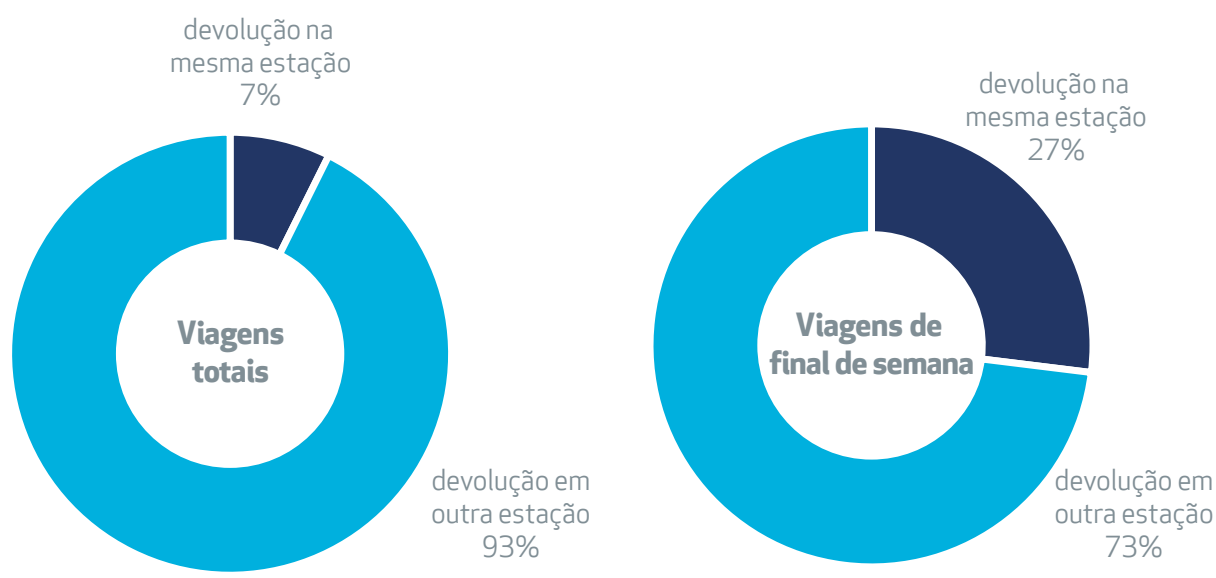

Gráfico 48 | Viagens totais e nos fins de semana realizadas com devolução na mesma estação ou em estações distintas de janeiro de 2018 a janeiro de 2019, no Bike Sampa Fonte: Tembici. Elaboração própria. 

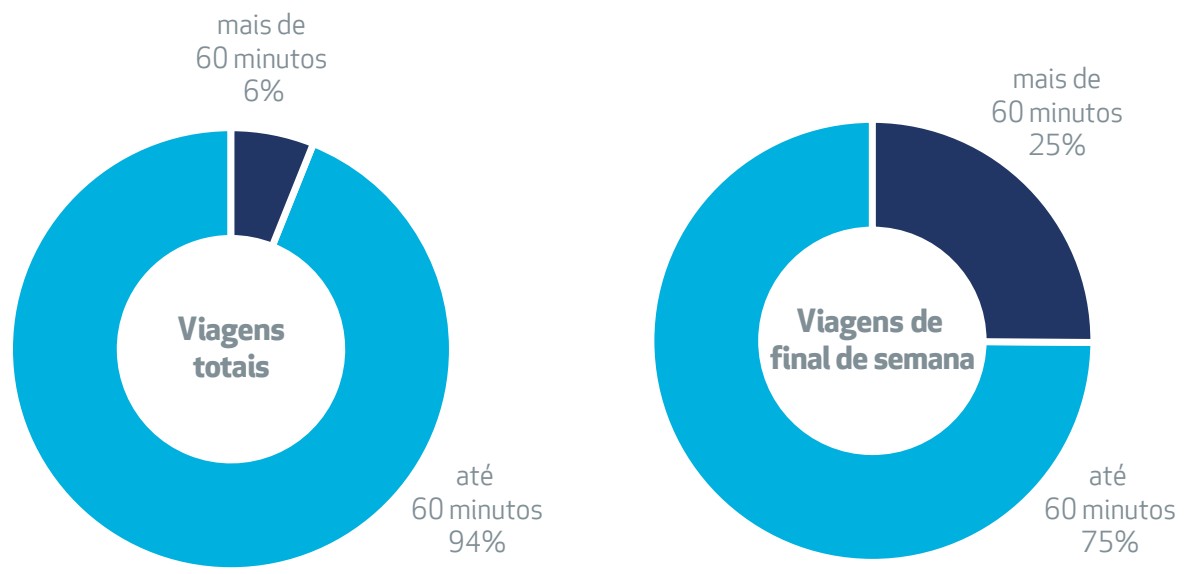

Gráfico 49 | Viagens totais e nos fins de semana realizadas até sessenta minutos de janeiro de 2018 a janeiro de 2019, no Bike Sampa Fonte: Tembici. Elaboração própria.

No Ecobici, 25\% do público săo mulheres, porcentagem semelhante à registrada no Bike Sampa, situaçâo indicada nos gráficos 50 e 51. As ciclistas em Săo Paulo, segundo a Pesquisa de Origem e Destino de 2007, representavam apenas 10\% desse universo, e nas contagens de ciclistas de 2015 e 2018 na Avenida Brigadeiro Faria Lima eram13\% e 20\%, respectivamente. Há maior adesăo de mulheres ao segmento de bicicletas compartilhadas, talvez pela segurança na utilizaçăo da última "perna" da viagem em locais com infraestrutura cicloviária e devido à possibilidade de integraçăo modal. No entanto, como comentado anteriormente, a participaçăo feminina no uso da bicicleta como meio de transporte continua muito baixa em ambas as cidades estudadas. 

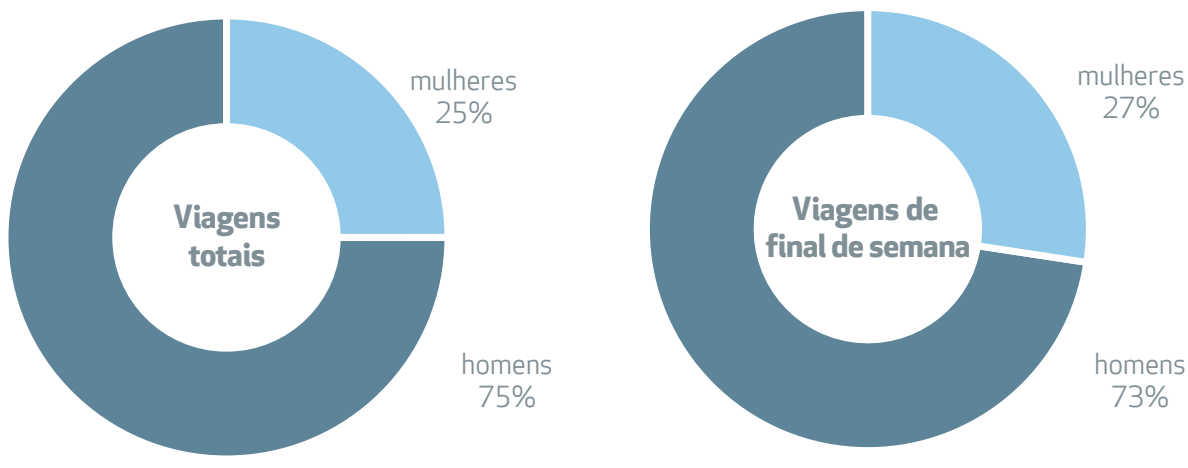

Gráfico 50 | Viagens totais e nos fins de semana por gênero no Ecobici, nos últimos doze meses (de janeiro de 2018 a janeiro de 2019)

Fonte: Ecobici. Elaboração própria.
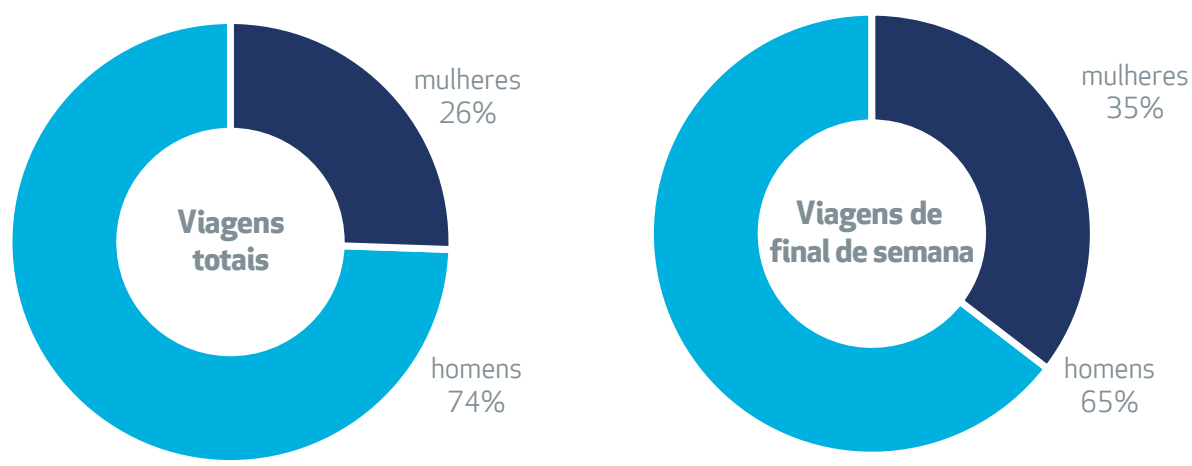

Gráfico 51 | Viagens totais e nos fins de semana por gênero no Bike Sampa, nos últimos doze meses (de janeiro de 2018 a janeiro de 2019)

Fonte: Ecobici. Elaboração própria. 


\subsection{Outros operadores em São Paulo}

\section{CicloSampa}

O CicloSampa, com patrocínio do Bradesco Seguros e operaçăo da empresa Trunfo, iniciou sua operaçăo em Săo Paulo em 2013, e possui hoje dezessete estaçóes, como indicado no mapa 14. Para utilizar o sistema, é necessário instalar o aplicativo e realizar o cadastro com os dados pessoais e o cartăo de crédito, escolher uma das estaçôes e a bicicleta e retirá-la com o aplicativo. Os primeiros trinta minutos săo gratuitos, e há custo de R\$6,00 a cada trinta minutos excedentes. Para devolver a bicicleta, basta encontrar qualquer estaçấo do sistema e encaixá-la na vaga disponível

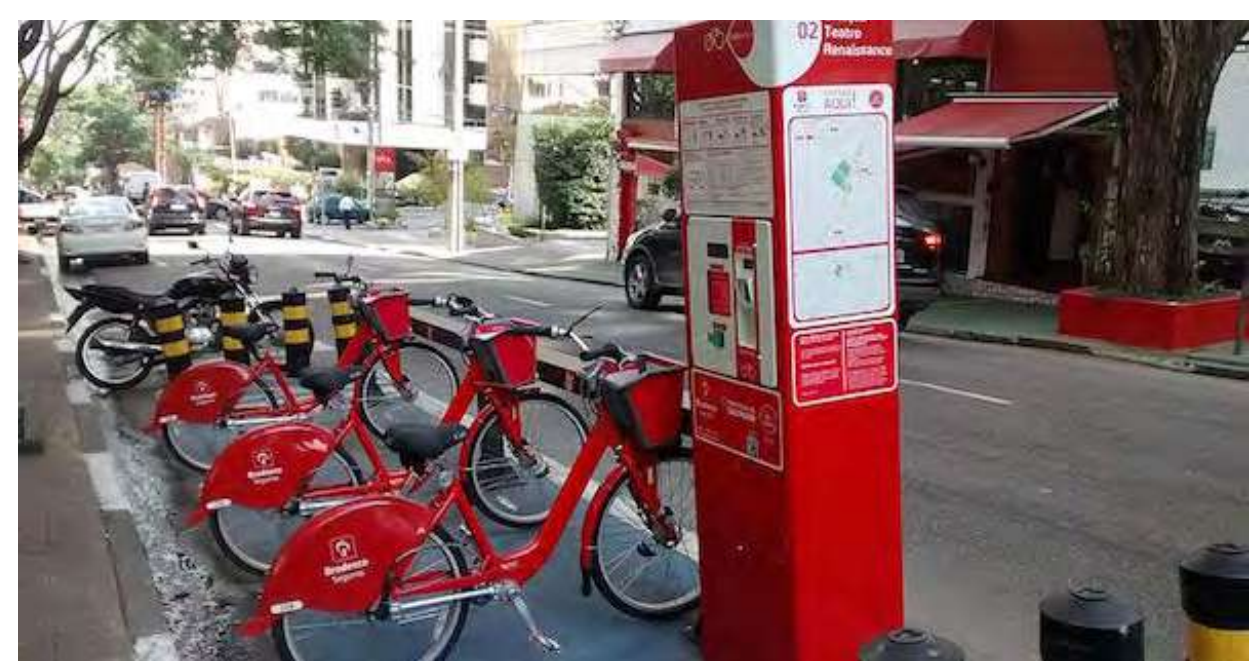

Foto 42 | Estação do CicloSampa

Fonte: Wille Marcel. 


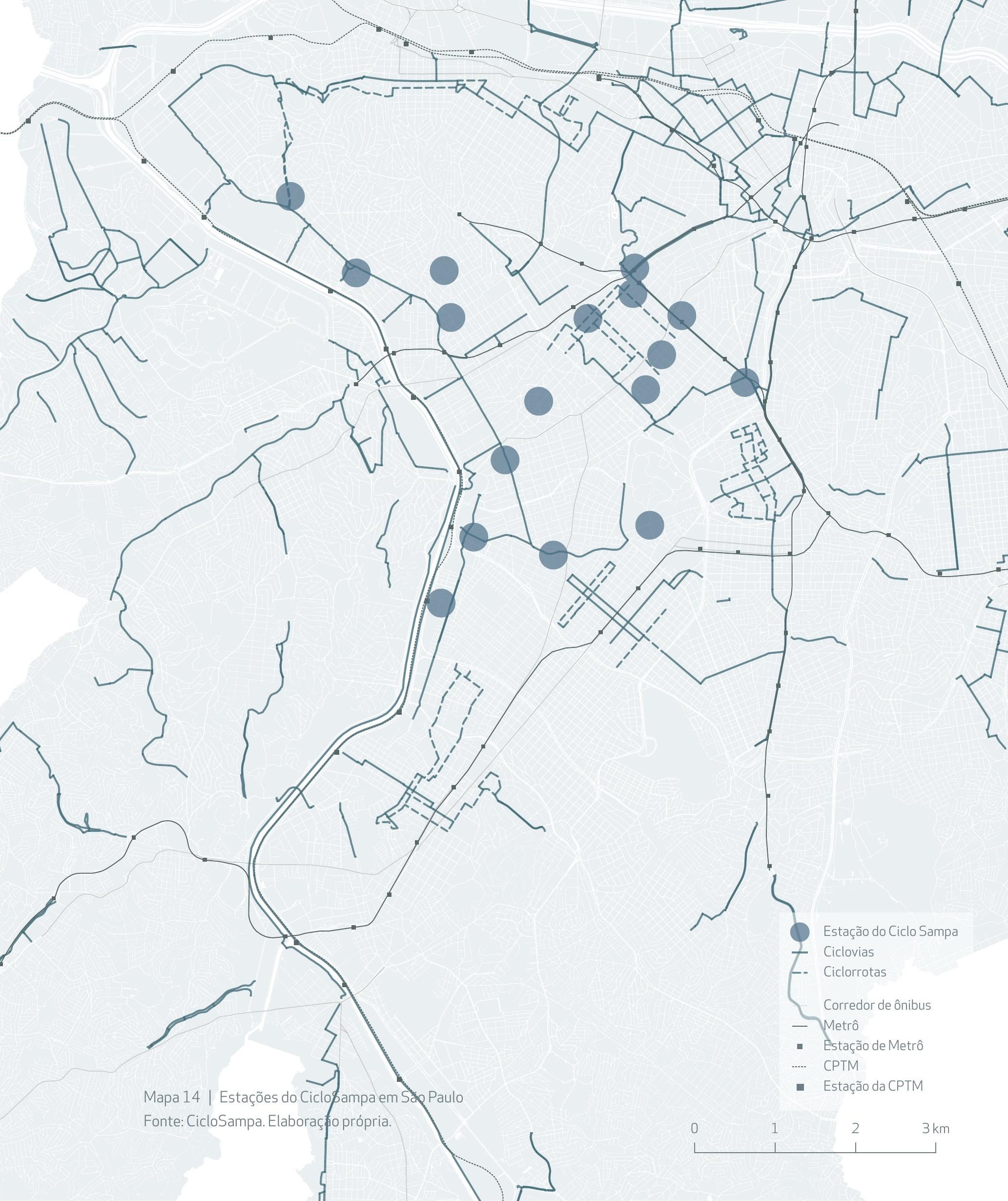




\section{Yellow Bike}

Iniciou a operaçăo em agosto de 2018 sem restriçăo de área de cobertura. 0 sistema dockless, como já descrito, permite a retirada e a devoluçáo das bicicletas em qualquer local da cidade, seja em calçadas, seja no leito carroçável, nos pontos físicos licenciados pela CET e pela subprefeitura. É necessário ter um smartphone com o aplicativo do sistema, e o valor utilizado (R $\$ 1,00$ a cada quinze minutos) é debitado dos créditos comprados com cartăo de crédito ou dinheiro.

Alguns problemas enfrentados, segundo Marina Karkot (2018), como falta de confiabilidade no GPS, fragilidade das bicicletas quebradas e o espraiamento das bicicletas na cidade, o que ocasiona dificuldade para a operaçăo, acarretaram a restriçăo da atuaçăo da empresa dois meses depois. Caso o usuário estacione fora dessa mancha, terá de pagar a taxa de resgate de $\mathrm{R} \$ 30,00$. 


\section{Como Funciona?}
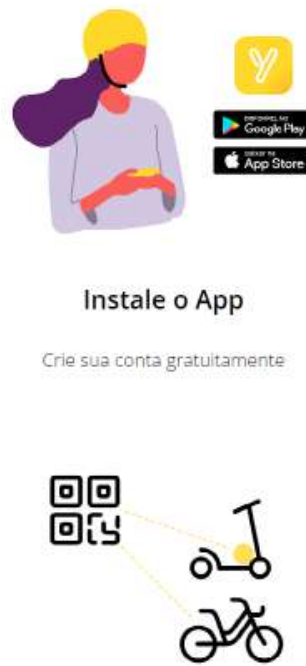

Localize e escaneie o QR code

Clique em "iniciar viagem" dentro do app para escanear $0 Q R$ code $e$ dcstravar sua Yellow

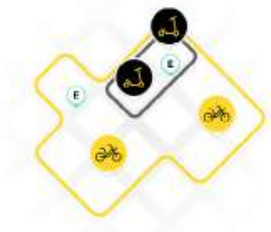

Encontre uma Yellow

Utilize o mapa para localizar a mais próxima de vocé

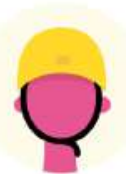

Viaje com segurança

Sempre verifique os freios e altura do banco. Respeite as leis de trânsito.

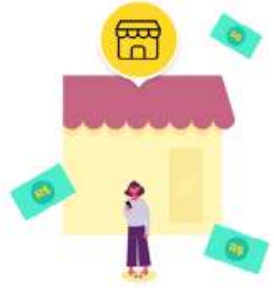

Coloque créditos na sua conta

Pague com cartāo de crédito ou dinheiro

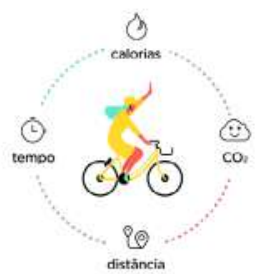

Finalize sua corrida

Feche o cadeado manualmente no caso da bike e finalize diretamente pelo upp no caso do patincte.

Figura 14 | Explicação do funcionamento do sistema Fonte: Yellow App.

Mesmo durante o processo de licenciamento dos pontos físicos das estaçôes, determinados na Resoluçăo n017 pelo poder público, a empresa já iniciou a operaçấo do sistema e introduziu na cidade milhares de bicicletas de compartilhamento dockless. $O$ fato de o funcionamento do sistema possibilitar o uso das bicicletas sem a necessidade dos pontos físicos permite burlar a burocracia e a demora do processo dos agentes envolvidos na emissâo das licenças do uso do espaço público. 
Apesar do início da pintura dos pontos físicos licenciados para estacionamento das bicicletas (no fim de 2018), ainda considero uma incógnita se elas ficarâo concentradas nesses locais. Como o sistema permite a devoluçăo da bicicleta em qualquer lugar da cidade, é muito mais cômodo para o usuário adaptar-se a essa regra, em vez de buscar pontos fixos para devoluçâo. Caberia à empresa responsável manejar as bicicletas para esses locais no prazo de dois dias estipulado pela Resoluçâo $n^{0} 17^{27}$. Só o tempo mostrará como esse processo vai funcionar.

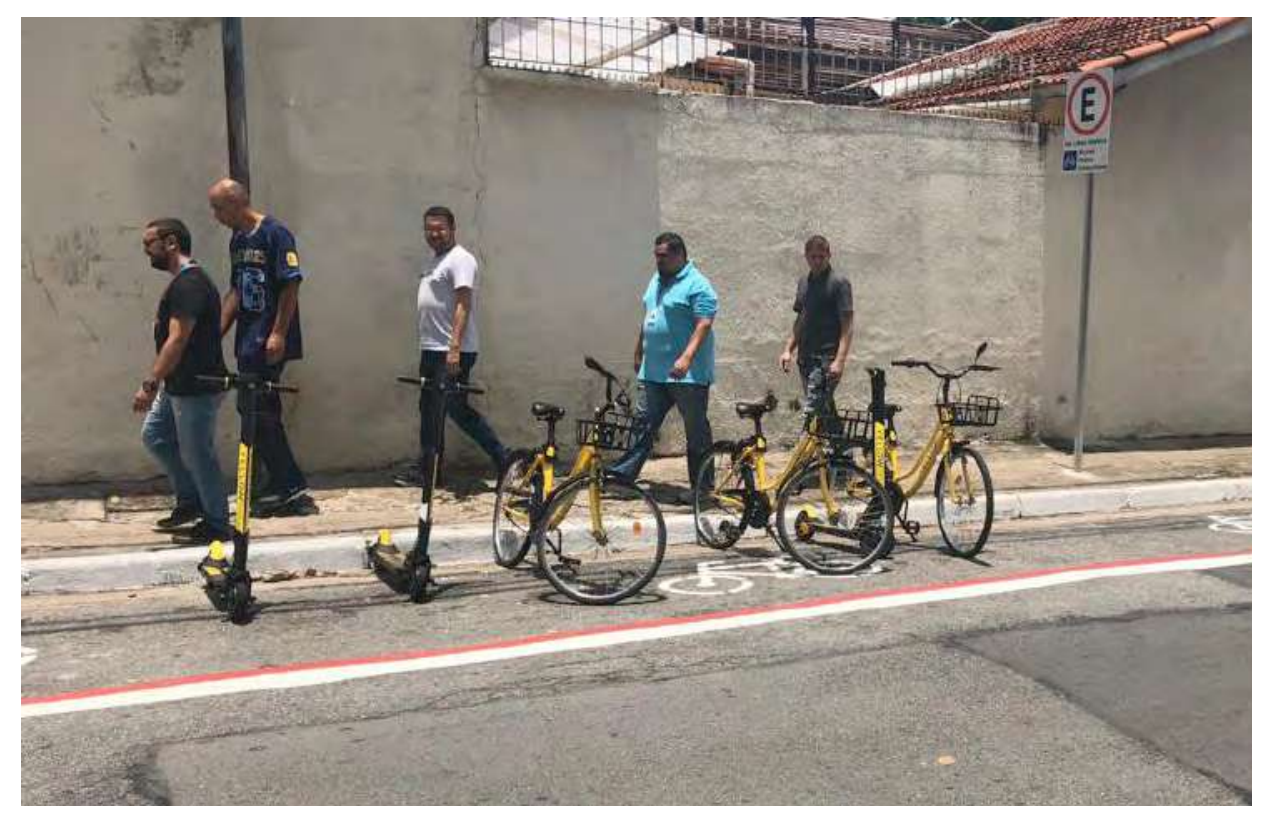

Foto 43 | Ponto fisíco de devolução de bicicleta dockless em São Paulo Fonte: Tembici (2018).

27 O Capítulo II da Resolução n 17 denota a necessidade das localizações georreferenciadas dos pontos para retirada e devolução das bicicletas para os sistemas sem estações e permite a livre devolução fora desses pontos com a condição de que a OTTC recolha essas bicicletas no prazo de até dois dias. 


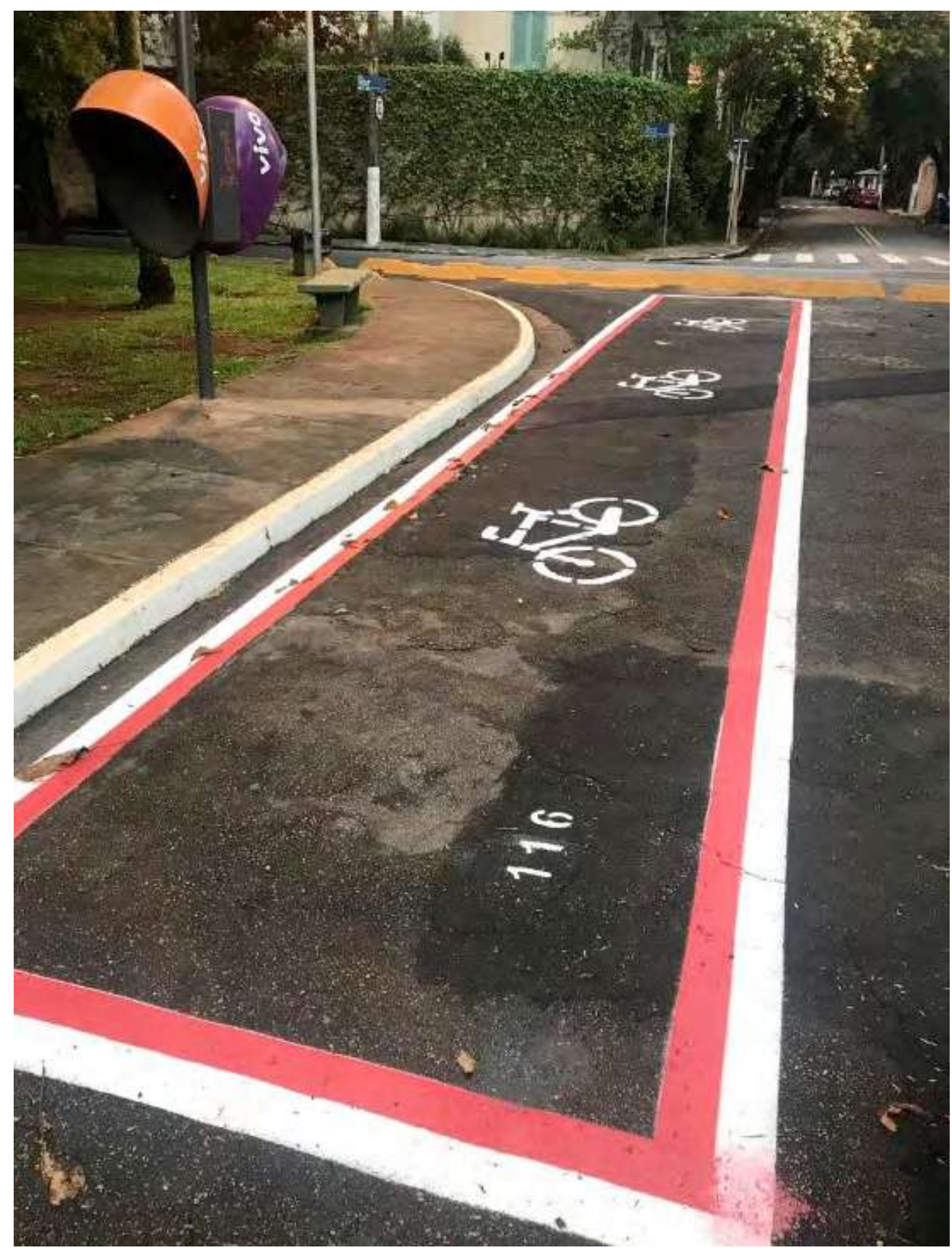

Foto 44 | Ponto fisíco de devolução de bicicleta dockless em São Paulo Fonte: Tembici (2018). 


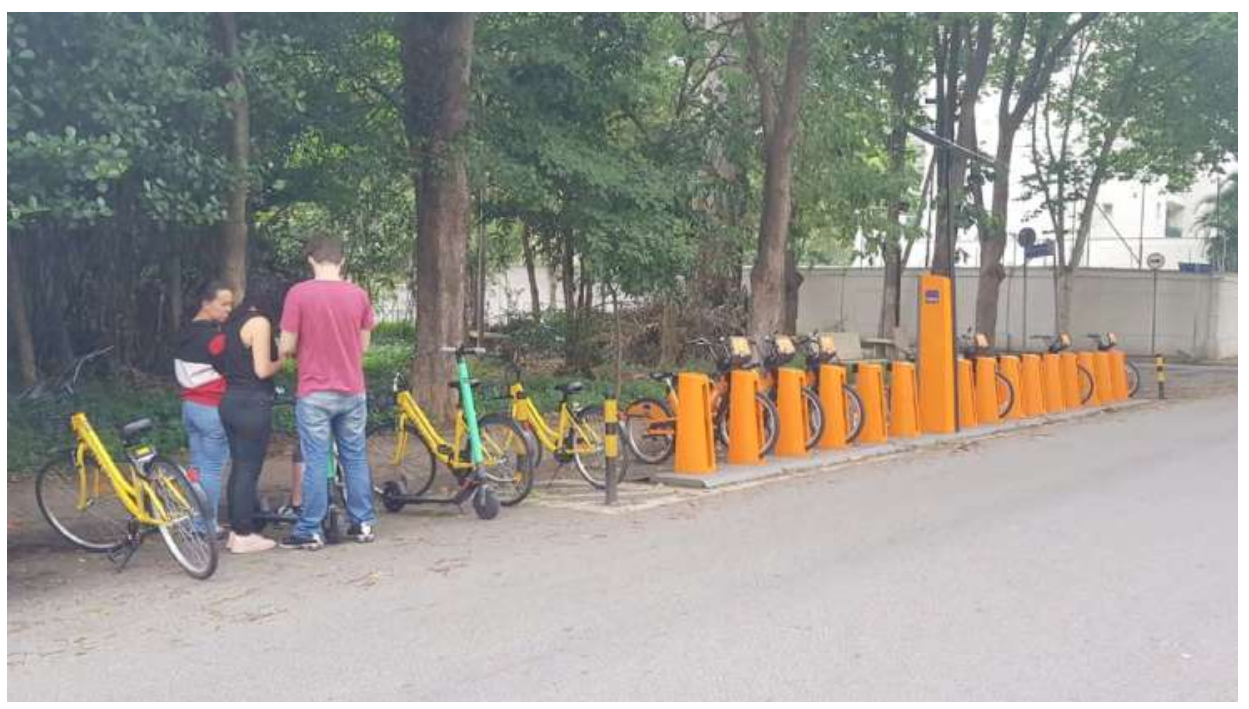

Foto 45 | Estação do Bike Sampa no leito carroçável, e bicicletas e patinetes dockless ao lado Fonte: Pedro Scaramuzza. 


\section{Patinetes elétricos: Yellow, Grin e Scoo}

Săo Paulo vivenciou o início do compartilhamento de patinetes elétricos no segundo semestre de 2018, com diversas empresas (Yellow, Grin e Scoo), concentrado na regiăo da Avenida Brigadeiro Faria Lima, Parque Ibirapuera e Avenida Paulista, em áreas com infraestrutura cicloviária para sua circulaçâo. Para utilizá-lo, é necessário baixar o aplicativo de cada empresa e escanear o código QR que fica na base do patinete com o aplicativo para desbloqueá-lo.

No caso da Scoo, tanto a retirada quanto a devoluçăo devem ser realizadas em um dos pontos localizados no mapa 16. Em janeiro de 2019, os locais limitavam-se à Avenida Paulista. A Yellow e a Grin ${ }^{28}$ têm a área de cobertura do sistema estabelecida e indicada no aplicativo. Dentro dessa regiăo, ambas possuem pontos físicos de estacionamento e solicita-se que a viagem seja encerrada preferencialmente nessas estaçôes, mas, caso isso năo seja possível, a empresa pede que o patinete seja deixado em algum local que năo atrapalhe a circulaçăo de pedestres e veículos. Ao devolver o patinete fora dessas condiçôes, será cobrada taxa de $\mathrm{R} \$ 30,00$. Para utilizar o sistema Yellow, é necessário dispor de crédito mínimo de R\$10,00.

De acordo com a Resoluçăo n 465 do Conselho Nacional de Trânsito (Contran), os equipamentos de mobilidade individual autopropelidos devem atentar à velocidade máxima de $6 \mathrm{~km} / \mathrm{h}$ em área de circulaçăo de pedestres e $20 \mathrm{~km} / \mathrm{h}$ em ciclovias e ciclofaixas. A bicicleta dotada de motor elétrico auxiliar pode circular em ciclovias e ciclofaixas se tiver potência máxima de 350 watts, trafegar em velocidade de até $25 \mathrm{~km} / \mathrm{h}$ e desde que o motor funcione somente quando o condutor pedalar.

28 As startups brasileira e mexicana, Yellow e Grin, anunciaram fusão em 30 de janeiro de 2019 


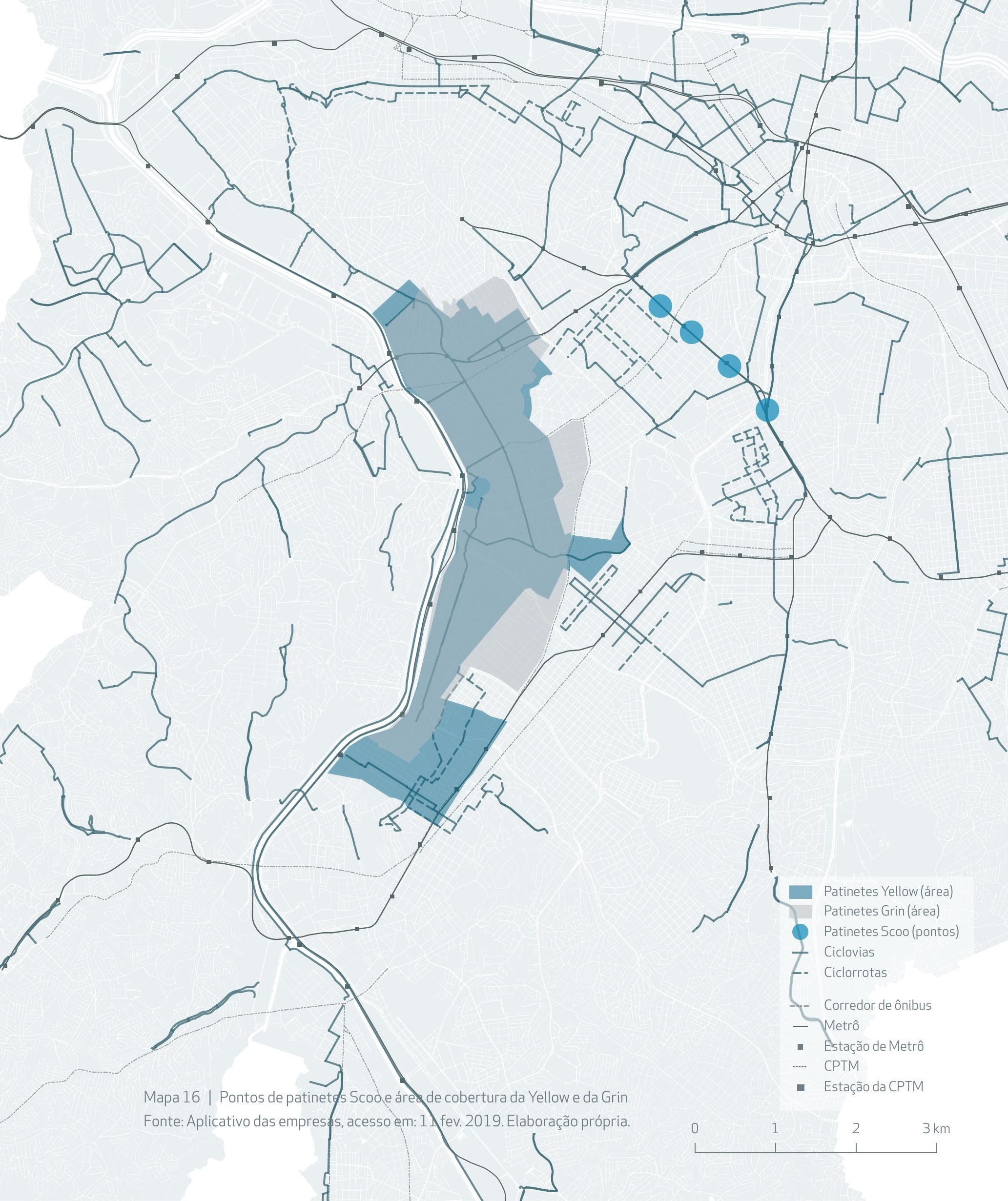




\subsection{Efeitos na mobilidade urbana de São Paulo}

A adesăo de muitos paulistanos aos diferentes modais nas áreas centrais, com o objetivo de evitar o trânsito e encontrar opçôes mais econômicas e rápidas de transporte, atesta a necessidade de investimento e incentivo às soluçôes diversificadas e conectadas de mobilidade.

A concentraçăo e a superposiçăo de todas as empresas em pequena área do centro expandido limitam o potencial de abrangência da populaçáo usuária dos sistemas. Acredito que isso aconteça pela junçăo de diversas características que configuram a regiăo como exitosa para os modais ativos de deslocamento: presença de infraestrutura cicloviária extensa; integraçáo modal com as estaçóes de metrô e de trem e com o corredor de ônibus; alta concentraçăo de empregos e serviços ao longo dessa infraestrutura, o que possibilita a conexăo com o transporte de massa; além de baixa declividade e menores índices de roubo.

As novidades de compartilhamento, como projeto piloto, estăo provando o funcionamento nesse eixo de alto fluxo de deslocamentos ativos, mas, para garantir melhora efetiva na qualidade de vida de maior número de paulistanos, será essencial expandir os serviços a outras regiôes da cidade. Incentivos e medidas devem ser pensados, principalmente pelo poder público, para viabilizar maior infraestrutura cicloviária nas proximidades do transporte público de massa e atrair investimento das empresas privadas para esses novos locais.

Conforme crítica de Lemos (2018), os investimentos estấo concentrados nas áreas mais ricas da cidade, já dotadas de infraestrutura e serviços e melhor 
qualidade de mobilidade. Entretanto, há incerteza sobre se esses serviços seriam viáveis em outros locais da cidade, pois eles dependem da adesăo ao uso cotidiano (que depende da infraestrutura cicloviária) e da baixa taxa de vandalismo e de roubo, pois a perda das bicicletas pode prejudicar de maneira drástica a viabilidade financeira do sistema.

Na tabela 9, seguem as informaçōes a respeito do preço dos diferentes sistemas existentes em Săo Paulo. Na comparaçăo valores cobrados pelo compartilhamento de patinete, percebe-se a diferença em relaçăo às taxas da bicicleta e do patinete compartilhados.

Com maior número de dados ao longo do tempo, será possível analisar qual o perfil do usuário de cada tipo de compartilhamento e principalmente que modo de transporte empregado anteriormente foi substituído pelo compartilhamento de mobilidades ativas. 


\begin{tabular}{|c|c|c|c|c|}
\hline Sistema & $\begin{array}{c}\text { Tembici (uma } \\
\text { viagem) }\end{array}$ & Tembici (mensal) & CicloSampa & Yellow Bike \\
\hline Custo do plano & $\begin{array}{c}\mathrm{R} \$ 2,00 \text { por } 60 \\
\text { minutos }[\mathrm{A}]\end{array}$ & $\mathrm{R} \$ 20,00[\mathrm{~B}]$ & $\begin{array}{c}\text { Gratuito nos } \\
\text { primeiros } 30 \\
\text { minutos }[\mathrm{C}]\end{array}$ & $\begin{array}{c}\mathrm{R} \$ 1,00 \text { a cada } 15 \\
\text { minutos }\end{array}$ \\
\hline $\begin{array}{c}\text { Custo de uma } \\
\text { viagem de } 15 \\
\text { minutos }\end{array}$ & $\mathrm{R} \$ 2,00$ & $\mathrm{R} \$ 1,00[\mathrm{D}]$ & Gratuito & $\mathrm{R} \$ 1,00$ \\
\hline
\end{tabular}

Tabela 9 | Custo de cada operador de sistemas de bicicletas compartilhadas de São Paulo

[A] $R \$ 5,00$ a cada sessenta minutos seguidos adicionais

[B] lbid.

[C] $R \$ 6,00$ a cada trinta minutos adicionais

[D] Considerou-se uma viagem realizada por dia, em vinte dias úteis no mês, no valor mensal de $\mathrm{R} \$ 20,00$.

Fonte: Dados disponíveis nos sites de cada empresa. Elaboração própria.

\begin{tabular}{|c|c|c|c|c|c|}
\hline Sistemas & Bikxi & Grin & $\begin{array}{l}\text { Yellow } \\
\text { Patinete }\end{array}$ & Scoo & $\begin{array}{l}\text { Patinete } \\
\text { Petrobrás }\end{array}$ \\
\hline Custo do plano & $\begin{array}{l}\mathrm{R} \$ 5,00 \text { por } \\
\text { corrida e entre } \\
\mathrm{R} \$ 2,50 / \mathrm{km} \text { e } \\
\mathrm{R} \$ 2,75 / \mathrm{km}\end{array}$ & $\begin{array}{l}\mathrm{R} \$ 3,00 \text { para } \\
\text { desbloqueio e } \\
\mathrm{R} \$ 0,50 \text { a cada } \\
\text { minuto }\end{array}$ & $\begin{array}{c}\mathrm{R} \$ 3,00 \text { para } \\
\text { desbloqueio } \\
\text { e } R \$ 0,50 \text { por } \\
\text { minuto }\end{array}$ & $\begin{array}{l}\mathrm{R} \$ 1,00 \text { para } \\
\text { desbloqueio } \\
\text { e } R \$ 0,25 \text { por } \\
\text { minuto }\end{array}$ & $\begin{array}{c}\mathrm{R} \$ 4,00 \text { a cada } \\
15 \text { minutos }\end{array}$ \\
\hline $\begin{array}{l}\text { Custo de uma } \\
\text { viagem de } 15 \\
\text { minutos }\end{array}$ & $\mathrm{R} \$ 8,90[\mathrm{~A}]$ & $\mathrm{R} \$ 10,50$ & $\mathrm{R} \$ 10,50$ & $\mathrm{R} \$ 4,75$ & $\mathrm{R} \$ 4,00$ \\
\hline
\end{tabular}

Tabela 10 | Custo de cada operador de sistemas de patinetes elétricos compartilhados e do sistema Bikxi ${ }^{29}$

[A] Previsão de preço cobrado na pesquisa de trajeto entre duas localizações do eixo da ciclovia da Avenida Brigadeiro Faria Lima, num percurso de catorze minutos, realizado no aplicativo do serviço. Fonte: Dados disponíveis nos sites de cada empresa. Elaboração própria.

29 Bikxi é o sistema de transporte compartilhado que utiliza bicicleta dupla elétrica guiadas por profissionais. Disponivel em:<https://bikxi.com.br/>. Acesso em: 27 jan. 2019. 


\subsubsection{Contador de ciclistas da Avenida Brigadeiro Faria Lima}

Dois equipamentos de contagem de ciclistas foram instalados pela Prefeitura de Săo Paulo em 2016 - um na Avenida Brigadeiro Faria Lima, na altura do número 1.200, e o outro na Rua Vergueiro, próximo do número 1.700. Os dados periódicos do fluxo de ciclistas săo essenciais para estudo da demanda e a evoluçâo gradual no uso da bicicleta.

No gráfico 52, estăo apresentados os dados dos contadores de ciclista da Avenida Brigadeiro Faria Lima e da Avenida Vergueiro. A regiăo da Faria Lima sempre apresentou maior fluxo e revelou aumento de uso a partir de março de 2018, com certa estabilizaçăo a partir de setembro.

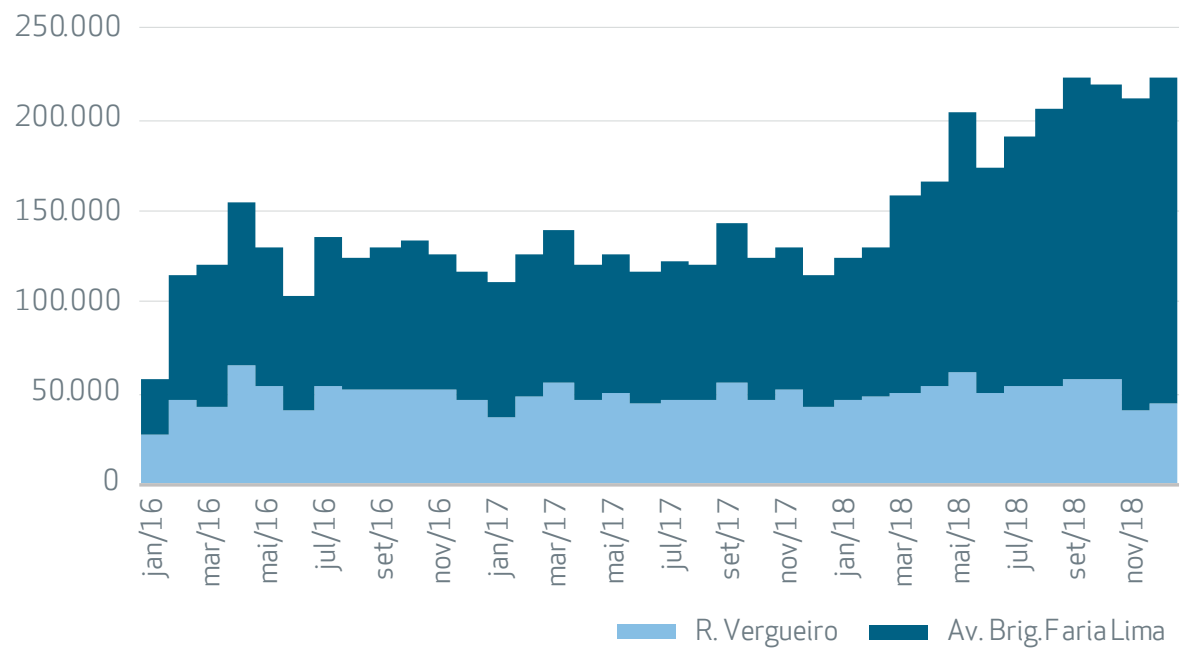

Gráfico 52 | Contagem mensal de ciclistas na rua Vergueiro, desde o início (18/01/2016 até 31/01/2018)

Fonte: Dados do Contador Faria Lima (desenvolvido por http://www.eco-compteur.com/pt/). 
No mês de setembro de 2017, passaram 90.237 ciclistas na Avenida Brigadeiro Faria Lima, o que representou aumento de 16\% em relaçăo a 2016. No mesmo mês de 2018 , houve aumento de $85 \%$ em relaçấo ao ano anterior, e chegou-se a 165.141 contagens.

\begin{tabular}{|c|c|c|}
\hline período & passagens & aumento \\
\hline de 1o a 30 de setembro de 2016 & 76.172 & - \\
\hline de 1o a 3o de setembro de 2017 & 90.237 & $18,46 \%$ \\
\hline De 1 a 30 de setembro de 2018 & 167.435 & $85,56 \%$ \\
\hline
\end{tabular}

Tabela 11 | Contagem do mês de setembro em 2016, em 2017 e em 2018 Fonte: Contador Faria Lima (Desenvolvido por http://www.eco-compteur.com/pt/).

Reportagem de Lazzeri (2018), da Folha de S.Paulo de 4 de agosto de 2018, denota o acréscimo de $45 \%$ do total de viagens na ciclovia da Faria Lima, de janeiro a julho de 2018, revelado pela CET, em comparaçáo com o mesmo período do ano anterior, sendo que na Rua Vergueiro o aumento foi de 10\%. Diversos fatores săo apresentados como responsáveis pelo aumento: a grande concentraçâo de escritórios e o deslocamento dos funcionários, a infraestrutura cicloviária segura e a alta concentraçáo de bicicletas compartilhadas na saída do metrô. 
Horários de chegada e saída do trabalho são campeões de fluxo

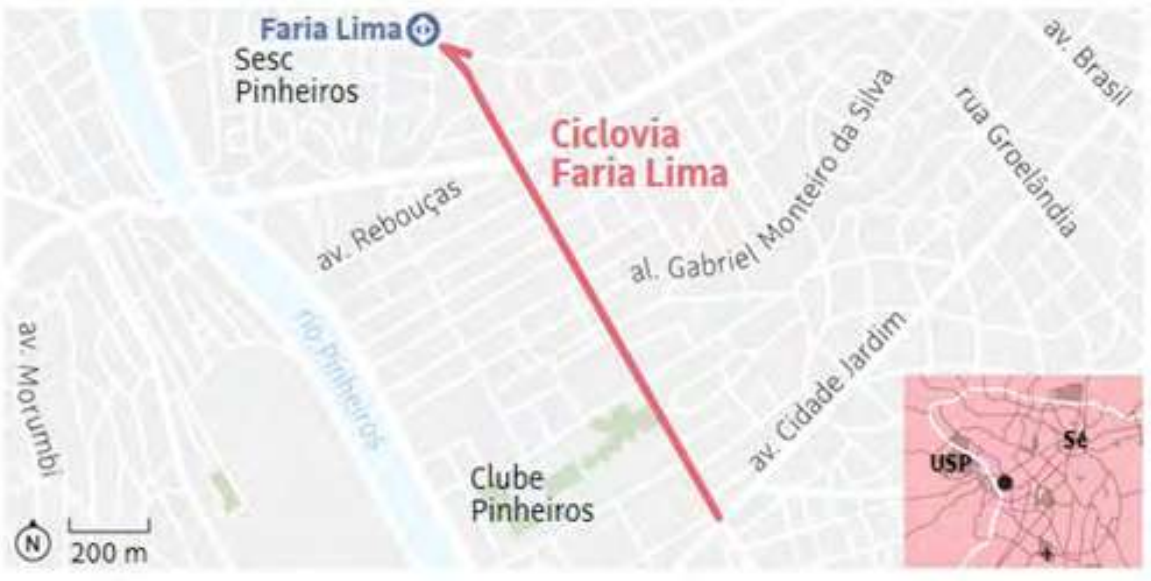

Viagens de janeiro a julho de cada ano, em milhares

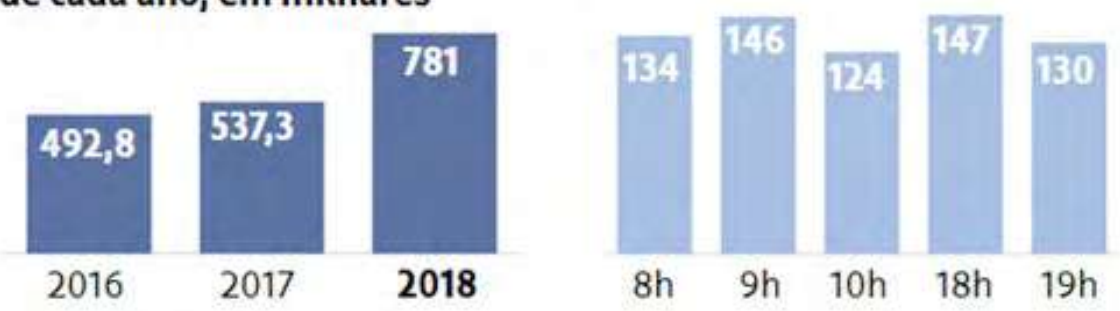

Figura 15 | Cresce movimento na ciclovia da av. Brigadeiro Faria Lima, em SP

Fonte: LAZZERI (2018). Levantamento do estúdio de análise de dados Novelo com base em informações obtidas via Lei de Acesso à Informação e Eco-Counter.

A inauguraçăo do novo Bike Sampa aconteceu no fim de janeiro de 2018, e pode ser um dos motivos que contribuíram para o aumento de viagens desse ano na Avenida Brigadeiro Faria Lima. A ciclovia da Vergueiro năo possui estaçôes de bicicleta compartilhada na regiăo e manteve número estável de ciclistas ao longo dos anos. 


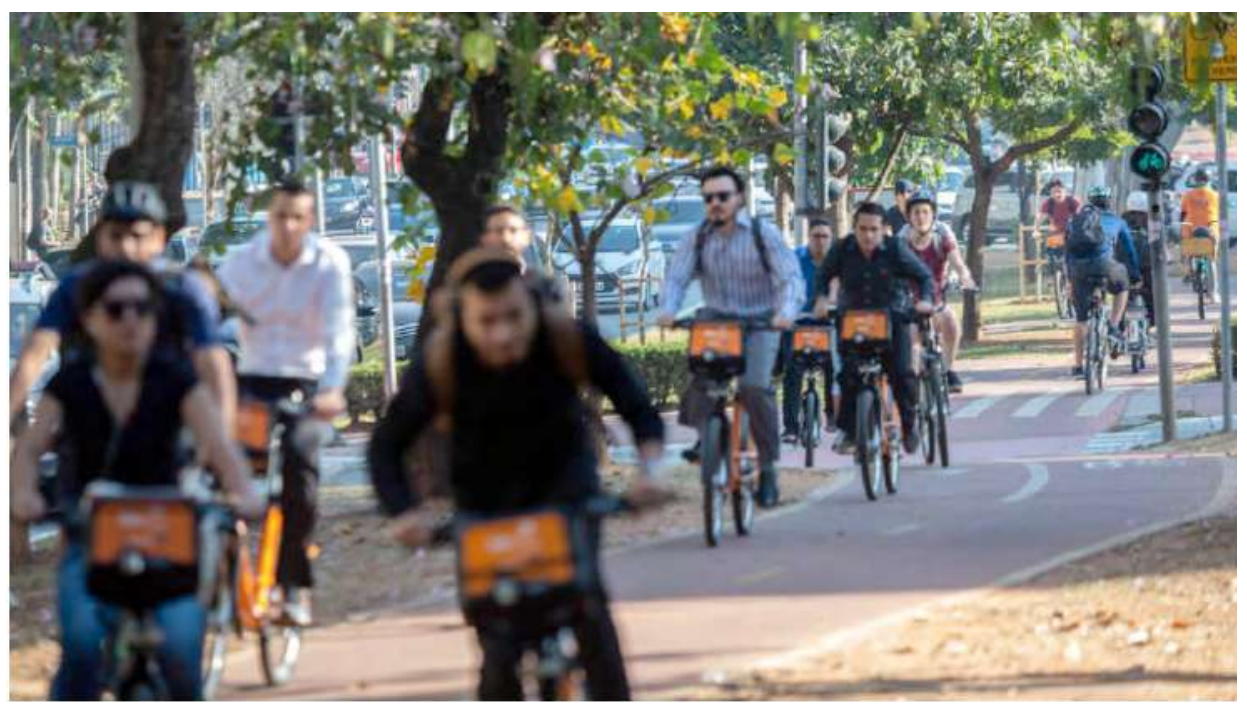

Foto 46 | Ciclistas na ciclovia da av. Brigadeiro Faria Lima

Fonte: Diego Padgurschi / Folhapess.

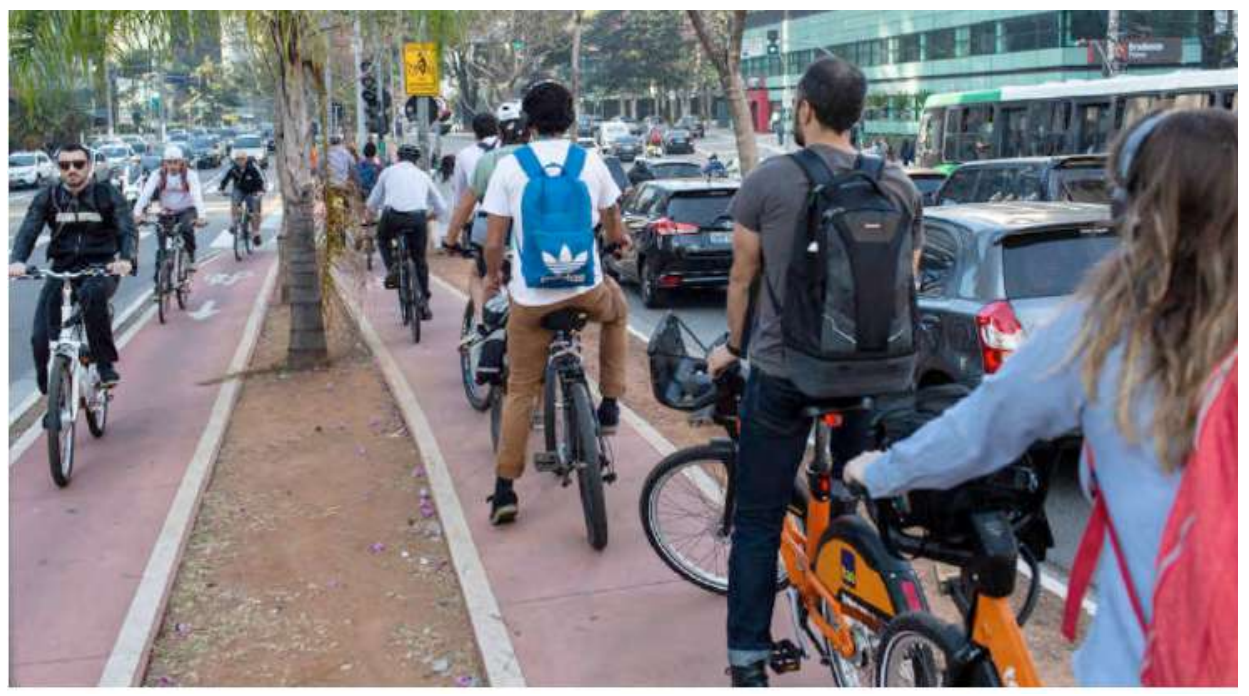

Foto 47 | Ciclistas parados no semáforo da ciclovia da Avenida Brigadeiro Faria Lima Fonte: Diego Padgurschi / Folhapess. 
Com o objetivo de entender o papel do sistema de bicicletas compartilhadas no incremento de viagens do eixo da Avenida Brigadeiro Faria Lima, foram analisados os dados dos relatórios de contagem de ciclistas, realizados pela Ciclocidade (2015a), nos anos 2013 e 2015, e foi contratada nova contagem em 2018.

\subsubsection{Contagem de ciclistas da Avenida Brigadeiro Faria Lima}

A contagem é utilizada em vários pontos da cidade para análise do fluxo e direçăo dos ciclistas e caracteriza-se como fonte essencial para identificar a evoluçăo ao longo do tempo e avaliar os efeitos de intervençōes nas vias. O método da contagem consiste na divisăo de turnos de duas horas e o preenchimento do formulário, considerando a direçâo dos ciclistas e outras características como gênero, idade, tipo de bicicleta (convencional, elétrica, de serviço, compartilhada, entre outros).

O relatório de 2015 feito pela Ciclocidade é referente à contagem de ciclistas realizada em 7 de abril de 2015, das 6 às 20 horas, no cruzamento da Avenida Brigadeiro Faria Lima com Avenida Rebouças, quando a ciclovia da Faria Lima se encontrava ainda incompleta, segundo projeto original ${ }^{30}$, com cruzamentos pouco sinalizados e velocidade máxima na avenida de $60 \mathrm{~km} / \mathrm{h}$

30 Em 2012, a ciclovia do canteiro central da Avenida Brigadeiro Faria Lima interligava a Avenida Cidade Jardim com a Rua dos Pinheiros. As obras para a reforma e a construção do restante foram iniciadas em 2014 e executadas ao longo de 2015. 


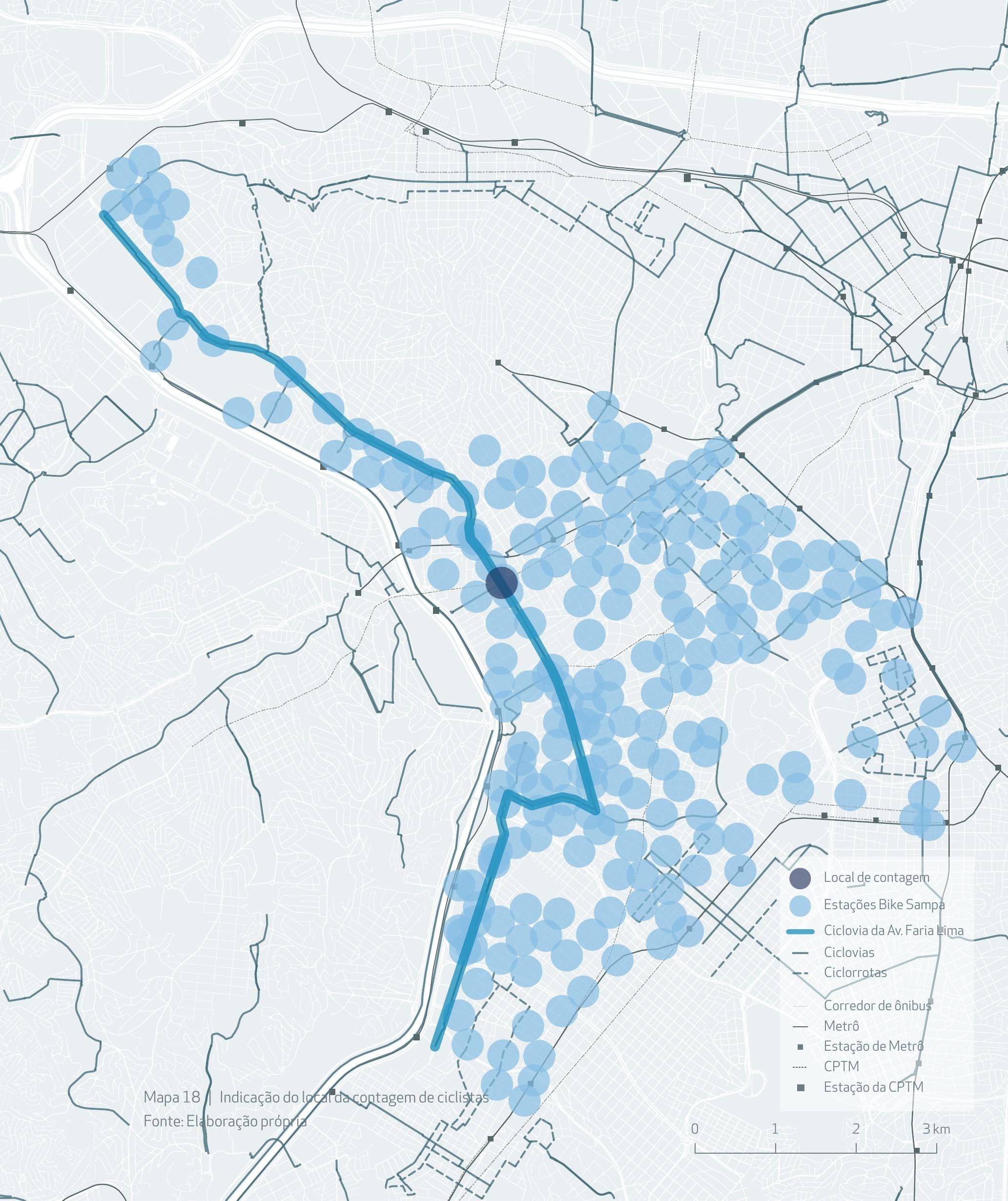




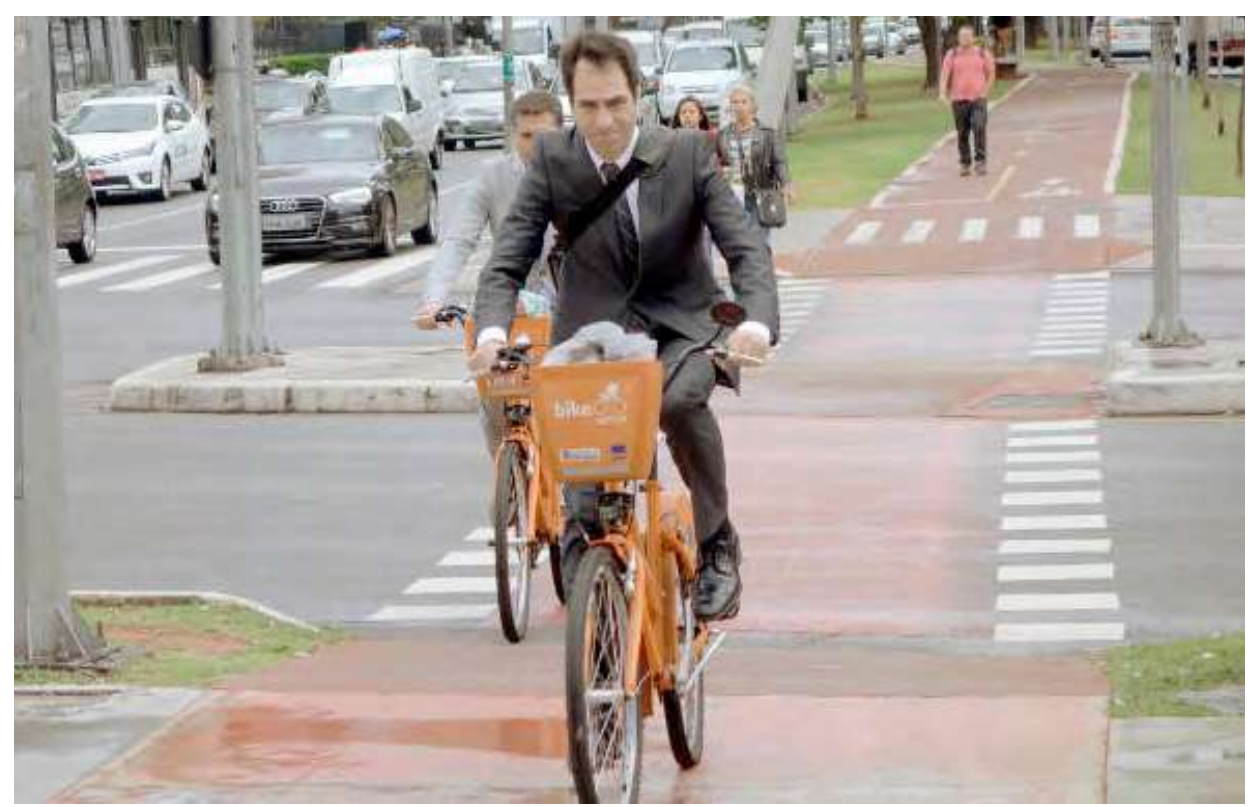

Foto 48 | Foto de ciclista utilizando Bike Sampa em 2015

Fonte: Ciclocidade, 2015a. Contagem de ciclistas 2015. 
Apesar de o dia apresentar períodos de chuva e frio, circularam ao longo dessas catorze horas 1.941 ciclistas, número que representou aumento de 14,5\% em relaçăo a 2013. Outras características relevantes săo apresentadas abaixo.

_13\% de mulheres (a maior participaçăo de mulheres ciclistas da cidade); _10\% de bicicletas compartilhadas. Entre 2013 e 2015, o uso das bicicletas compartilhadas do Bike Sampa dobrou (de 100 para 199); _2\% de bicicletas elétricas.

Nova contagem da Ciclocidade foi contratada para a presente pesquisa no mesmo local, durante catorze horas, das 6 às 20 horas, em 6 de dezembro de 2018. O dia apresentava temperatura estável e quente e circularam 9.111 pessoas, o que mostra aumento de $370 \%$ em relaçáo a 2015. As mesmas caraterísticas foram analisadas.

_20\% de mulheres;

_48\% de bicicletas compartilhadas;

_3\% de bicicletas elétricas;

8\% de patinetes elétricos compartilhados.

Considera-se o fluxo nos dois sentidos da Avenida Brigadeiro Faria Lima, onde há ciclovia no canteiro central e nos dois sentidos da Avenida Rebouças, eixo importante de conexăo do bairro Butantă ao centro, porém sem infraestrutura cicloviária, com corredor de ônibus e velocidade máxima de $50 \mathrm{~km} / \mathrm{h}$. A via com infraestrutura para ciclistas apresentou dez vezes mais fluxo do que na outra direçăo, como demonstra a figura 16. 


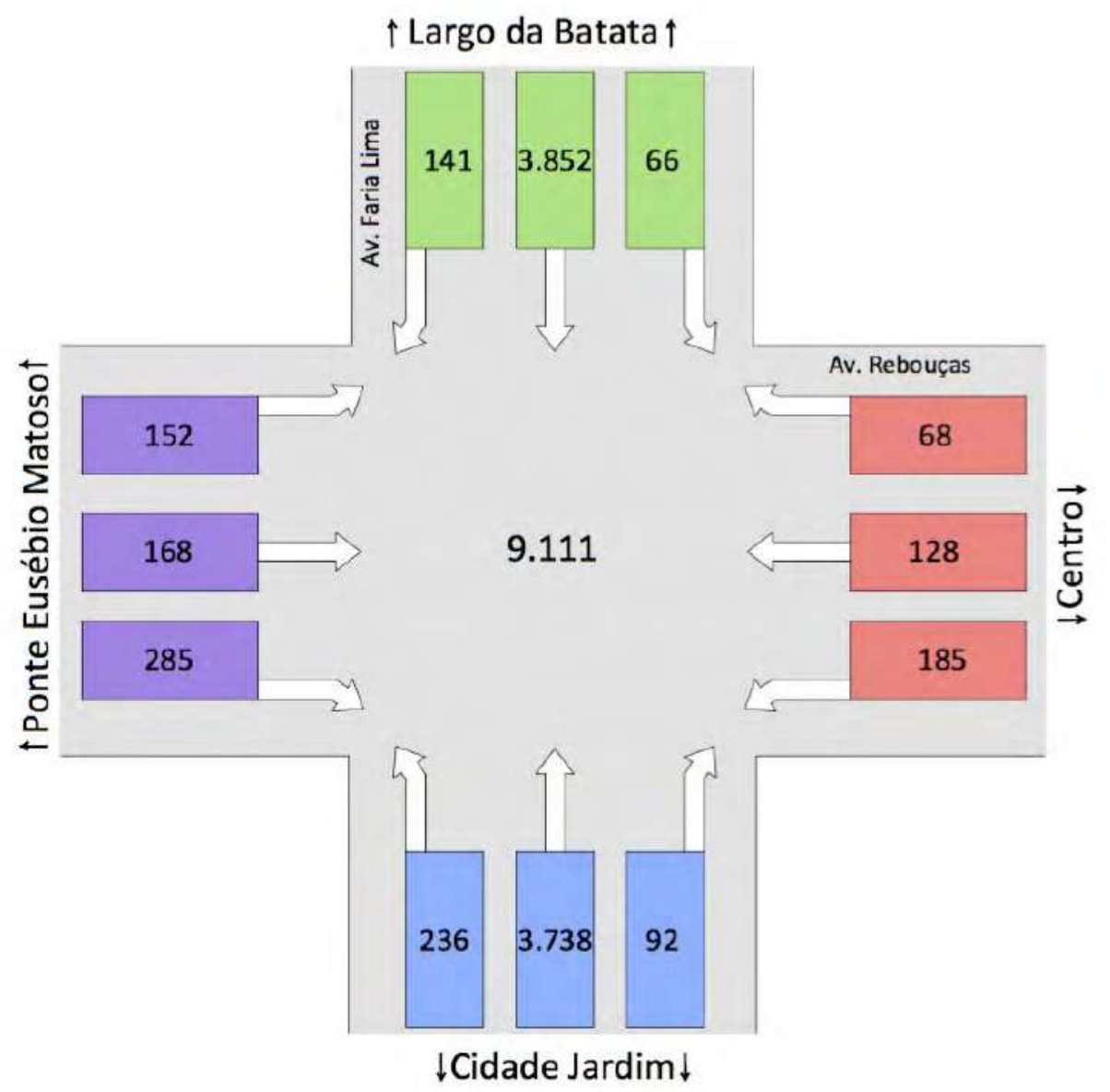

Figura 16 | Fluxo de ciclistas no eixo da Avenida Brigadeiro Faria Lima e na Avenida Rebouças Fonte: Ciclocidade, 2018a. Contagem de ciclistas 2018. 
A média do fluxo de ciclistas por hora aumentou de aproximadamente 120, em 2015, para 650, em 2018, chegando a 2.032 ciclistas no pico da manhá (das 8 às 10 horas) e 2.438 no pico da tarde (das 18 às 20 horas). 0 gráfico 53 mostra a relaçăo de ciclistas por gênero, de 2013 a 2018, que passou de $12 \%$ de mulheres em 2013 para 20\% em 2018 e o número total contabilizado na contagem. E o gráfico 54, indica o número de ciclistas por hora, com dois picos acentuados, no início da manhă e no final do dia, revelando, possivelmente, o motivo do trabalho das viagens.

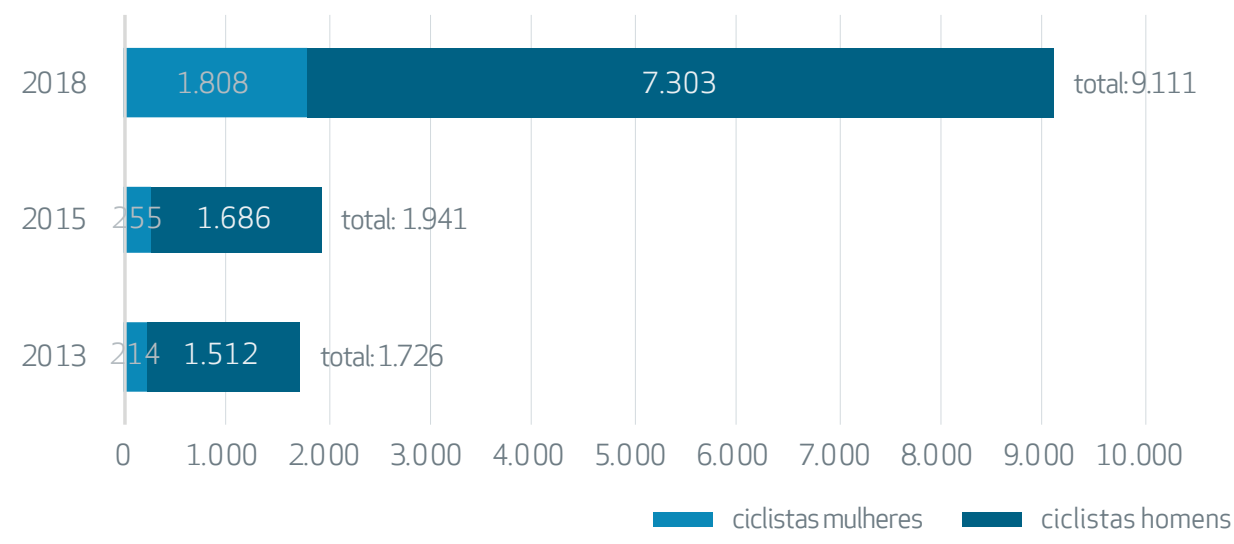

Gráfico 53 | Número de ciclistas em 2013, 2015 e 2018

Fonte: Ciclocidade, 2018a. Relatório da contagem de 2018. 


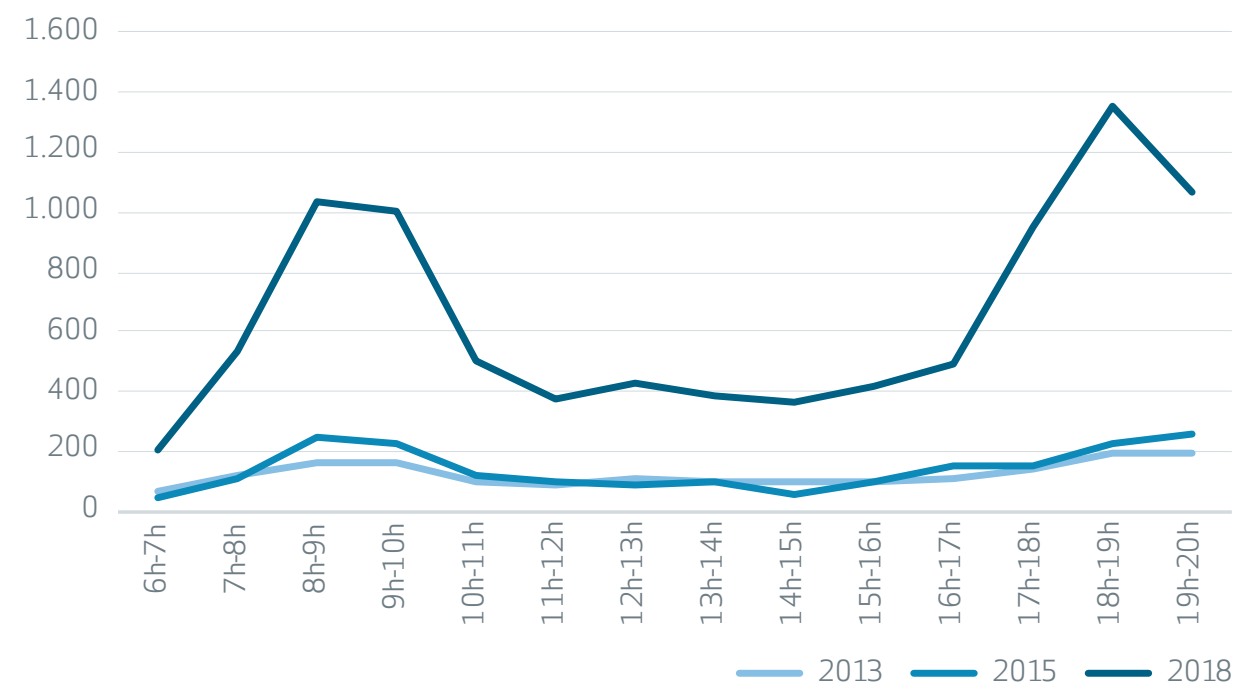

Gráfico 54 | Fluxo de ciclistas por hora em 2013, 2015 e 2018

Fonte: Ciclocidade, 2018a. Relatório da contagem de 2018. Elaboração própria.

Em 2018, os modos de deslocamentos compartilhados contribuíram com $59 \%$ das contagens nessa avenida (gráfico 55). A maior oferta desse tipo de serviço possibilitou e incentivou o uso do deslocamento ativo. Em 2015, só existia o Bike Sampa, que tinha a fatia de apenas 10\% do uso de veículos de compartilhamento.

No gráfico 56, há a relaçăo dos diferentes modais de deslocamento ativo contabilizados na contagem de 2018 pela Ciclocidade. Usuários do Bike Sampa representam 34\% das viagens, ciclistas com bicicleta comum própria, 32\% e usuários da Yellow Bike, 15\%, o que soma quase $80 \%$ dos deslocamentos. Os $20 \%$ restantes foram distribuídos entre patinetes de compartilhamento Grin e Yellow (8\% no total), bicicletas cargueiras e de serviço (5\%), bicicletas elétricas (3\%), Bikxi (2\%), e outros (patins, skates, patinete próprio, monociclo-2\%). 


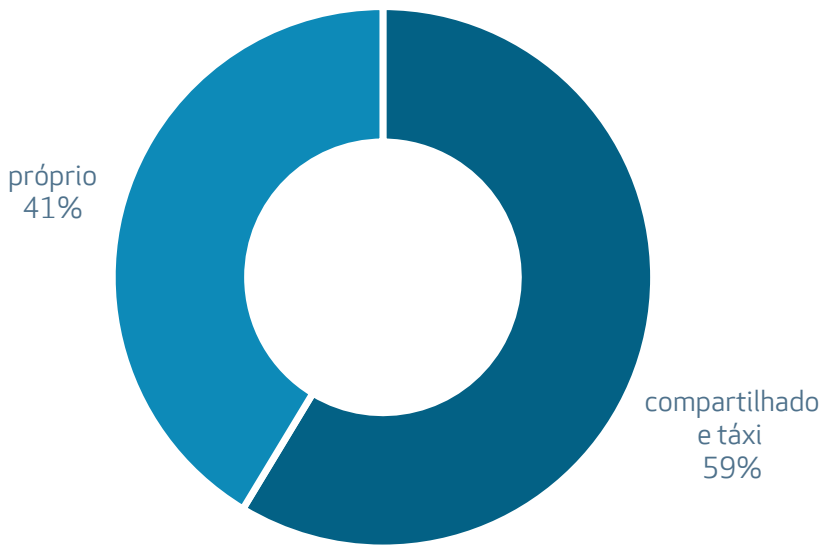

Gráfico 55 | Modais de deslocamento próprios e compartilhados Fonte: Ciclocidade, 2018a. Relatório da contagem de 2018. Elaboração própria.

\begin{tabular}{|c|c|c|}
\hline Tipo Modal & Contagem & \% em relação ao total \\
\hline Bike Sampa & 3070 & $34 \%$ \\
\hline Bike Comum & 2889 & $32 \%$ \\
\hline Yellow Bike & 1342 & $15 \%$ \\
\hline Patinete Grin & 483 & $5 \%$ \\
\hline Serviço, Cargueira ou Triciclo & 449 & $5 \%$ \\
\hline Elétrica & 317 & $3 \%$ \\
\hline Patinete Yellow & 255 & $3 \%$ \\
\hline Bikxi & 194 & $2 \%$ \\
\hline Outros: skate, patins, etc. & 69 & $1 \%$ \\
\hline Patinete Próprio & 43 & $0 \%$ \\
\hline TOTAL & 9111 & $100 \%$ \\
\hline
\end{tabular}

Tabela 12 | Características das pessoas na contagem 2018, sendo o total 9.111 pessoas (100\%) Fonte: Ciclocidade, 2018. Relatório da contagem de 2018. 


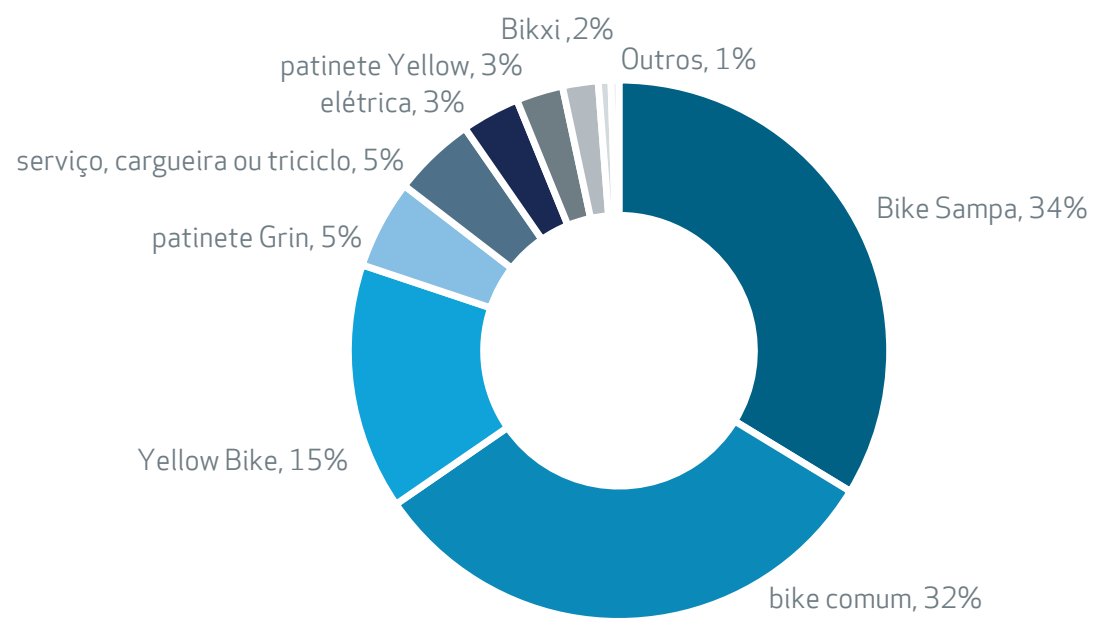

Gráfico 56 | Modais ativos contabilizados na contagem de 2018

Fonte: Ciclocidade, 2018a. Relatório da contagem de 2018. Elaboração própria.

A contribuiçăo das bicicletas compartilhadas, Bike Sampa e Yellow, foi de quase a metade das passagens da contagem de 2018 (gráfico 57). 0 comparativo das viagens feitas com o Bike Sampa de 2013 até 2018 é revelado no gráfico 58. Em 2013, o Bike Sampa realizou 6\% das viagens, em 2015, 10\% e em 2018, 34\%, enquanto as bicicletas Yellow responderam por 15\% das viagens. 
bicicleta compartilhada

(Bike Sampa e Yellow) $48 \%$

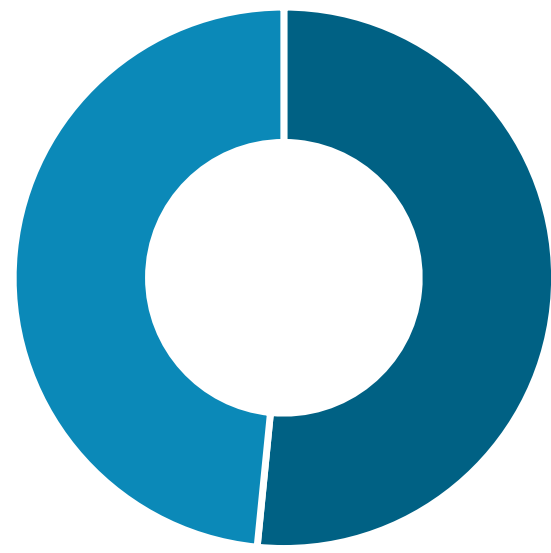

outros

$52 \%$

total da contagem: 9.111

Gráfico 57 | Número total de bicicletas compartilhadas

Fonte: Ciclocidade, 2018a. Relatório da contagem de 2018.

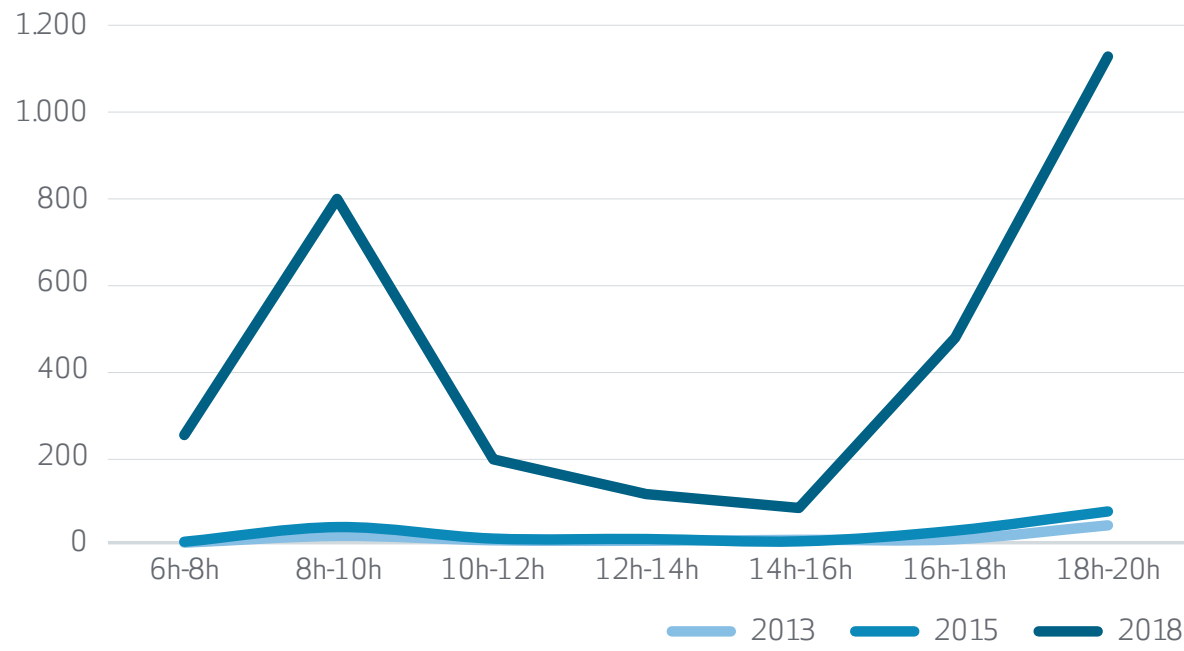

Gráfico 58 | Bike sampa por turno de contagem em 2013, 2015 e 2018

Fonte: Ciclocidade, 2018a. Relatório da contagem de 2018. 


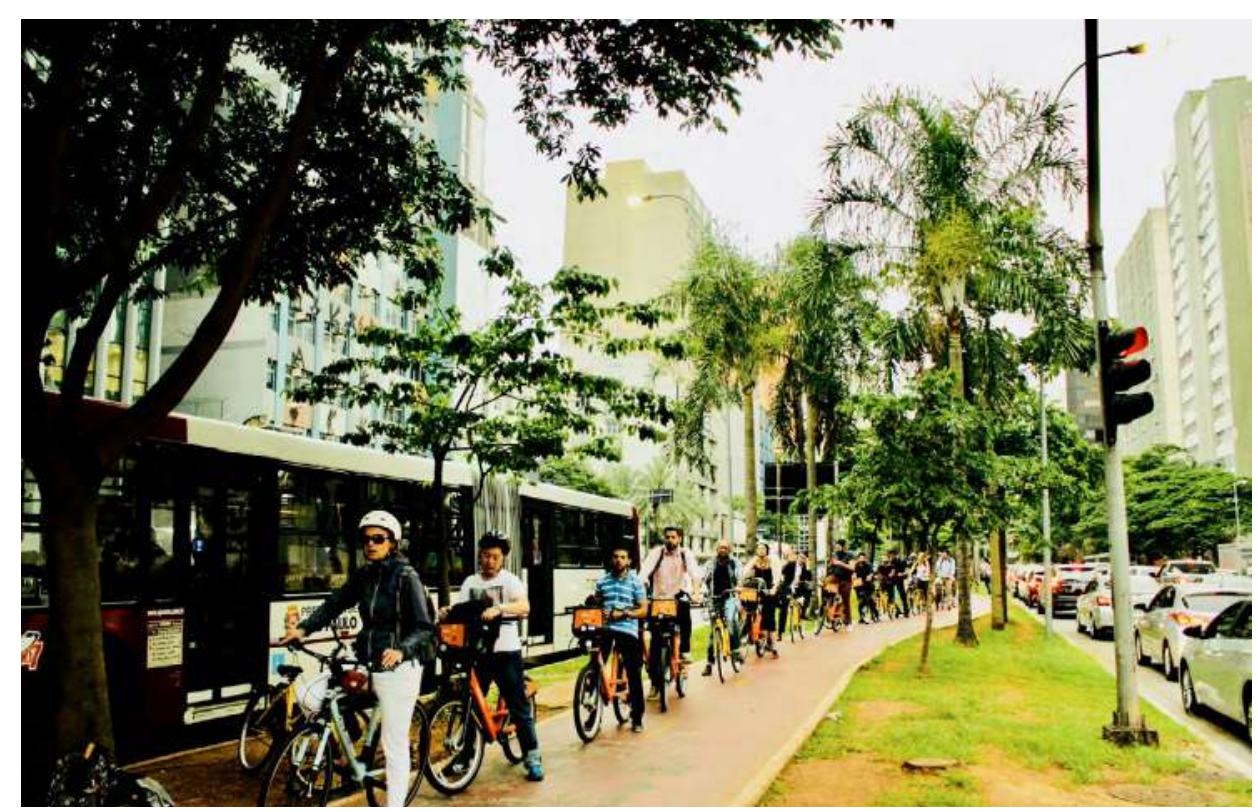

Foto 49 | Fila de ciclistas no semáforo da ciclovia da Faria Lima, esquina com a Avenida Rebouças, com a presença de muitas bicicletas compartilhadas do Bike Sampa Fonte: Rachel Schein, 6 dez. 2018.

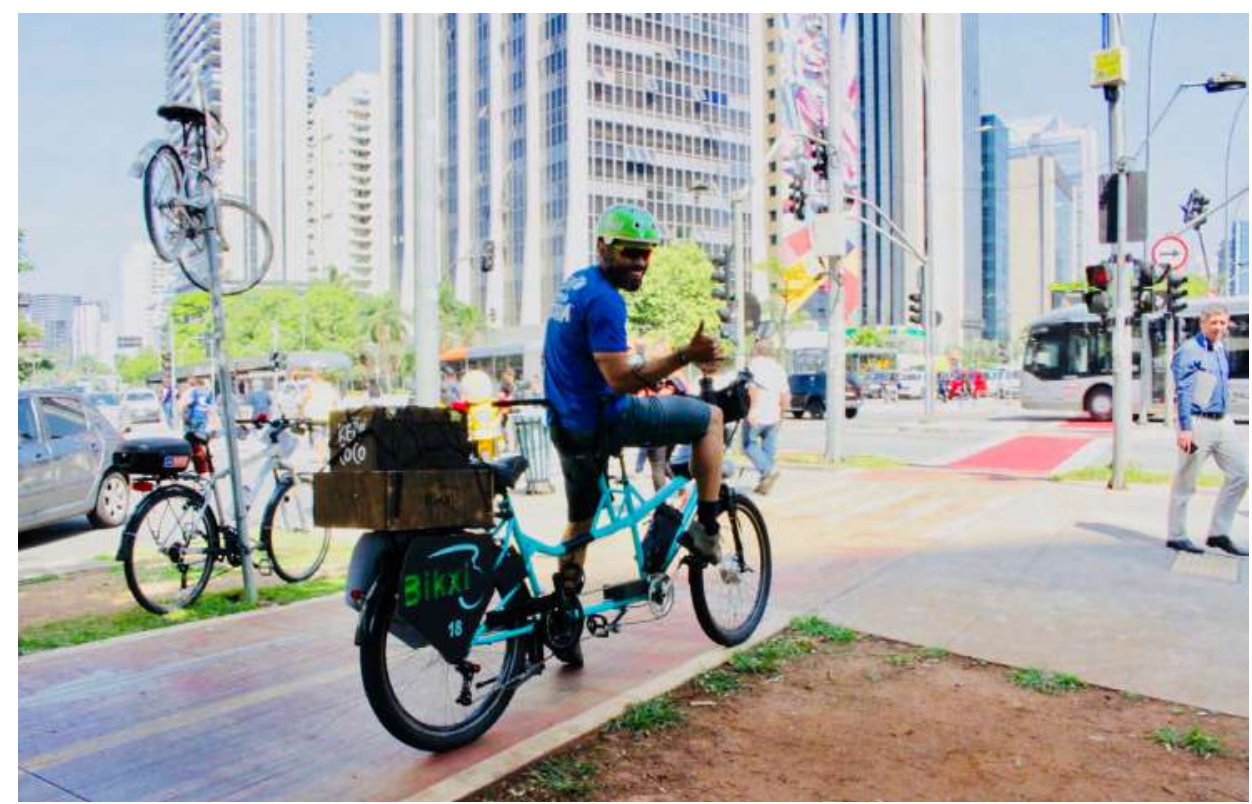

Foto 50 | Bikxi

Fonte: Rachel Schein, 6 dez. 2018. 


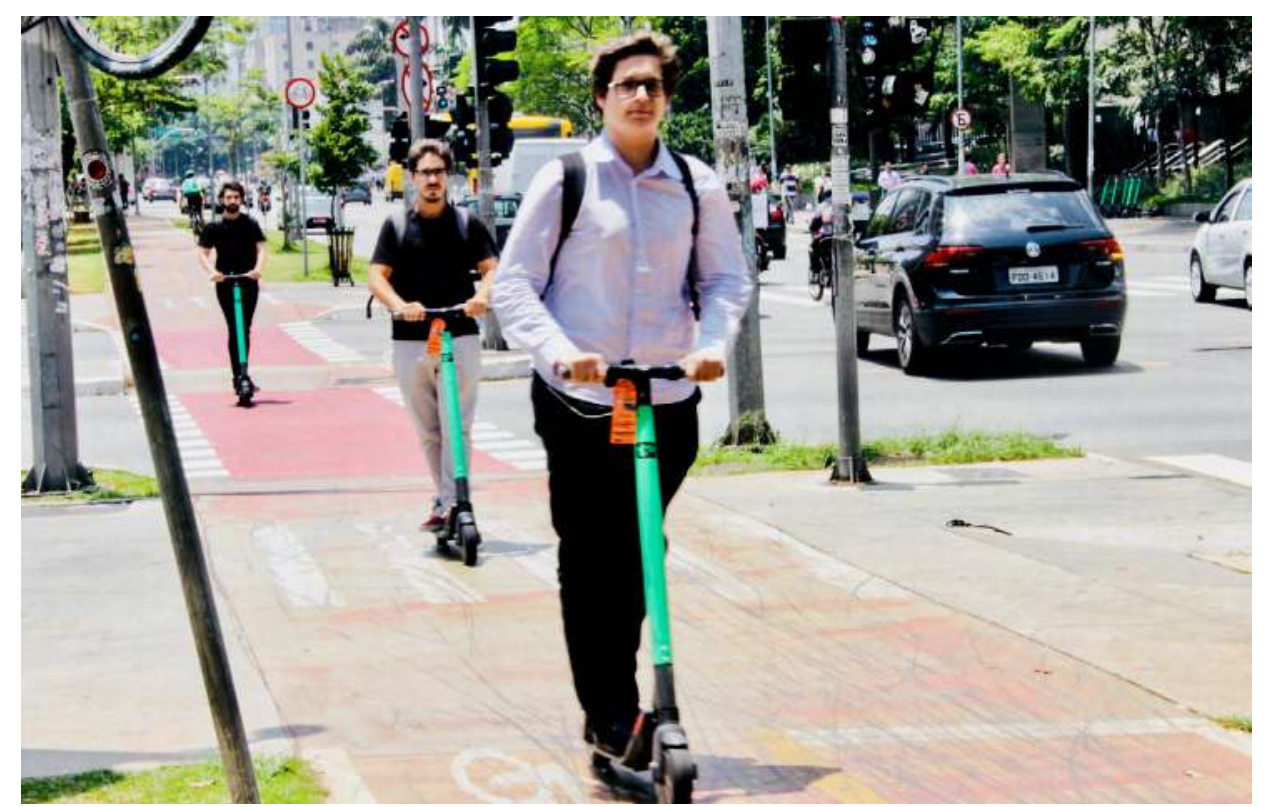

Foto 51 | Patinete elétrico compartilhado (Grin)

Fonte: Rachel Schein, 6 dez. 2018.

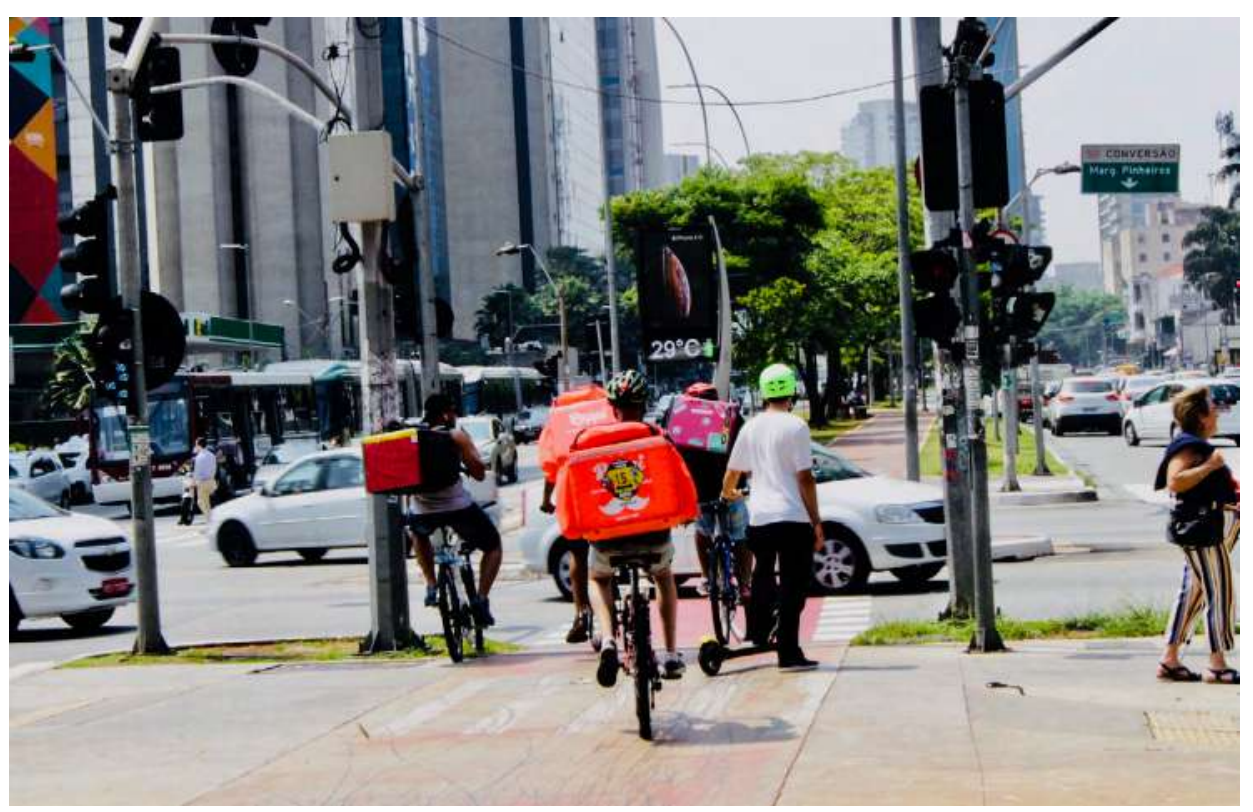

Foto 52 | Bicicletas de serviço de entrega

Fonte: Rachel Schein, 6 dez. 2018. 


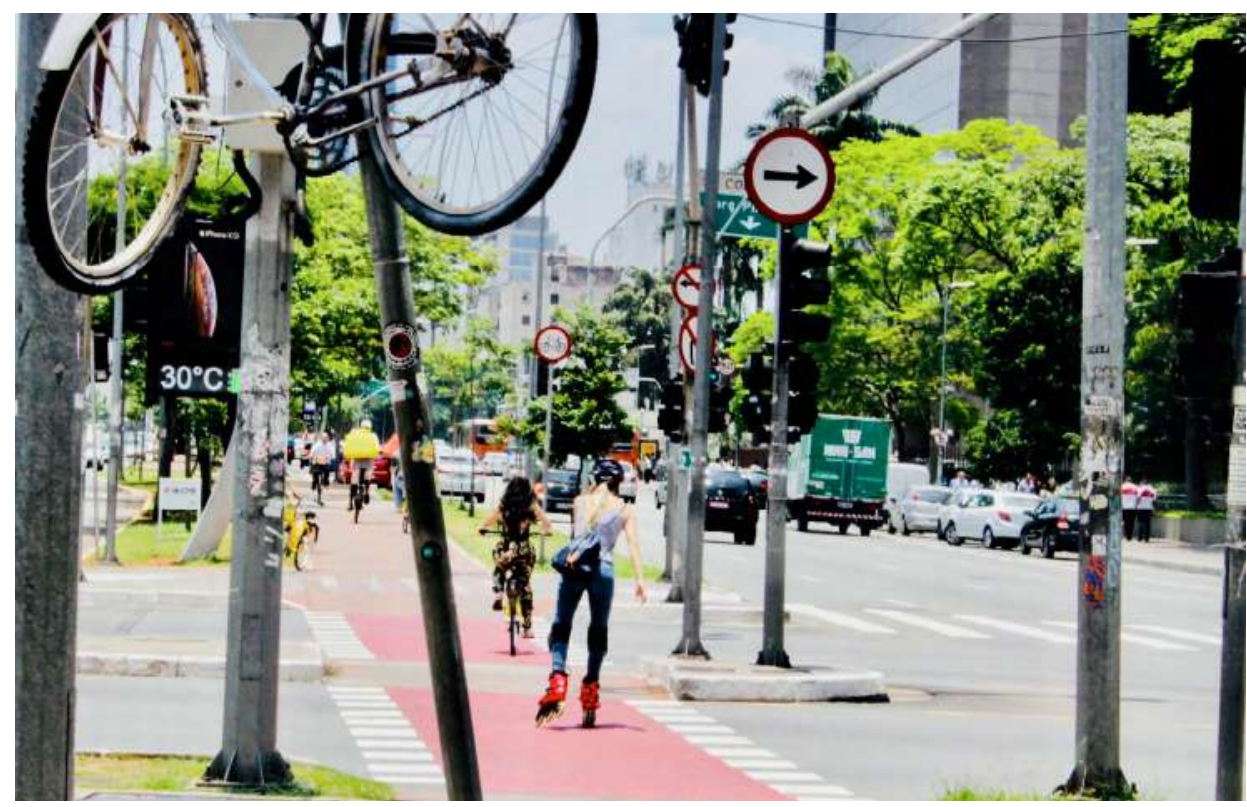

Foto 53 | Patins

Fonte: Rachel Schein, 6 dez. 2018.

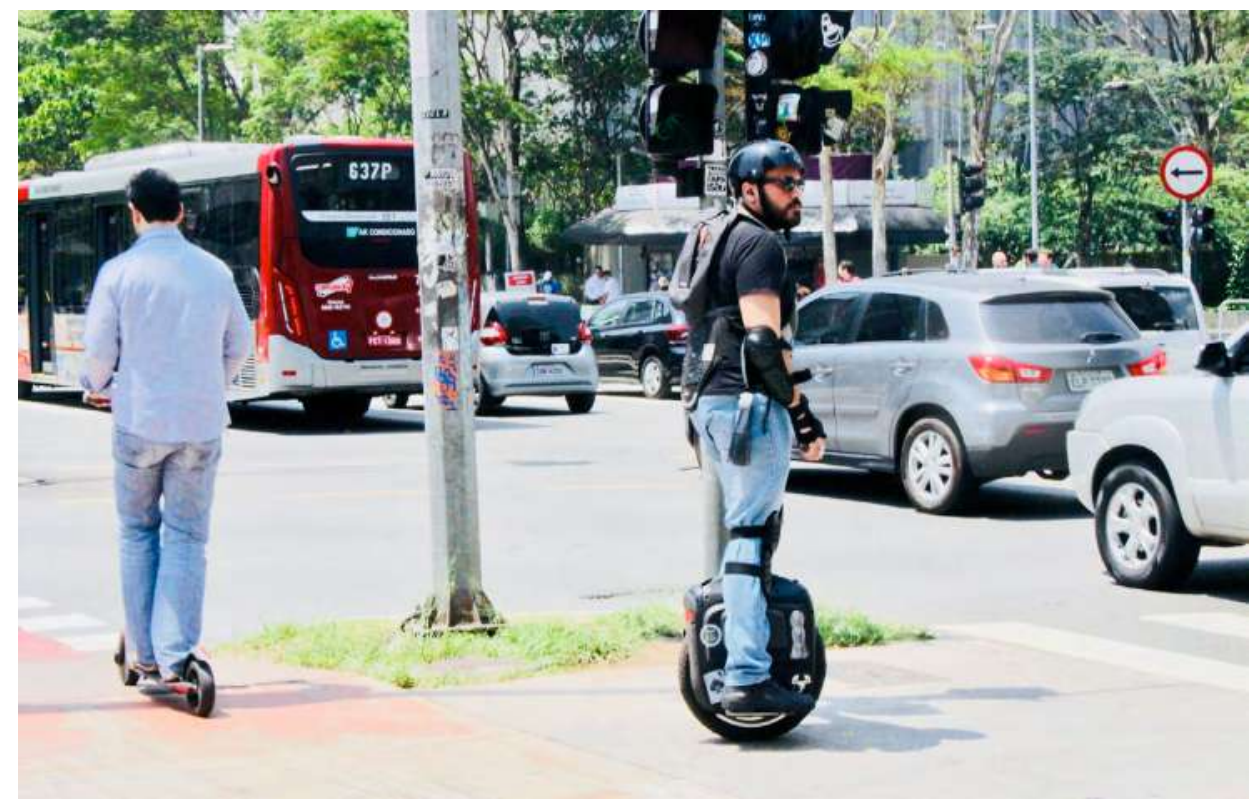

Foto 54 | Monociclo elétrico

Fonte: Rachel Schein, 6 dez. 2018. 


\subsubsection{Pesquisa com ciclistas paulistanos}

Para promover açóes na semana de mobilidade em setembro de 2018 e conhecer melhor o perfil do usuário de bicicleta, com foco no sistema Bike Sampa, a empresa Tembici contratou a Cidade Ativa ${ }^{31}$ para aplicar a metodologia de pesquisa e análise dos painéis interativos. Foram estudados diversos aspectos, como gênero, idade, modo de deslocamento e trajetos, assim como a motivaçấo para o uso da bicicleta e as causas da năo adoçăo desse meio de transporte no cotidiano.

A coleta de dados foi realizada em dois dias ${ }^{32}$, durante doze horas (das 8 às 20 horas), em dois locais da área de cobertura do sistema: na estaçăo 1 (Largo da Batata) do Bike Sampa, ao lado do metrô Faria Lima (linha amarela) e na estaçăo 131 (próximo ao portăo 6 do Parque Ibirapuera), para obter maior diversidade de perfil dos usuários.

31 A Cidade Ativa é uma organização social cujo objetivo consiste na criação de cidades mais inclusivas, resilientes e saudáveis, por meio do incentivo a comportamentos ativos.

32 Um dia útil (27 set. 2018) e um domingo (30 set. 2018). 


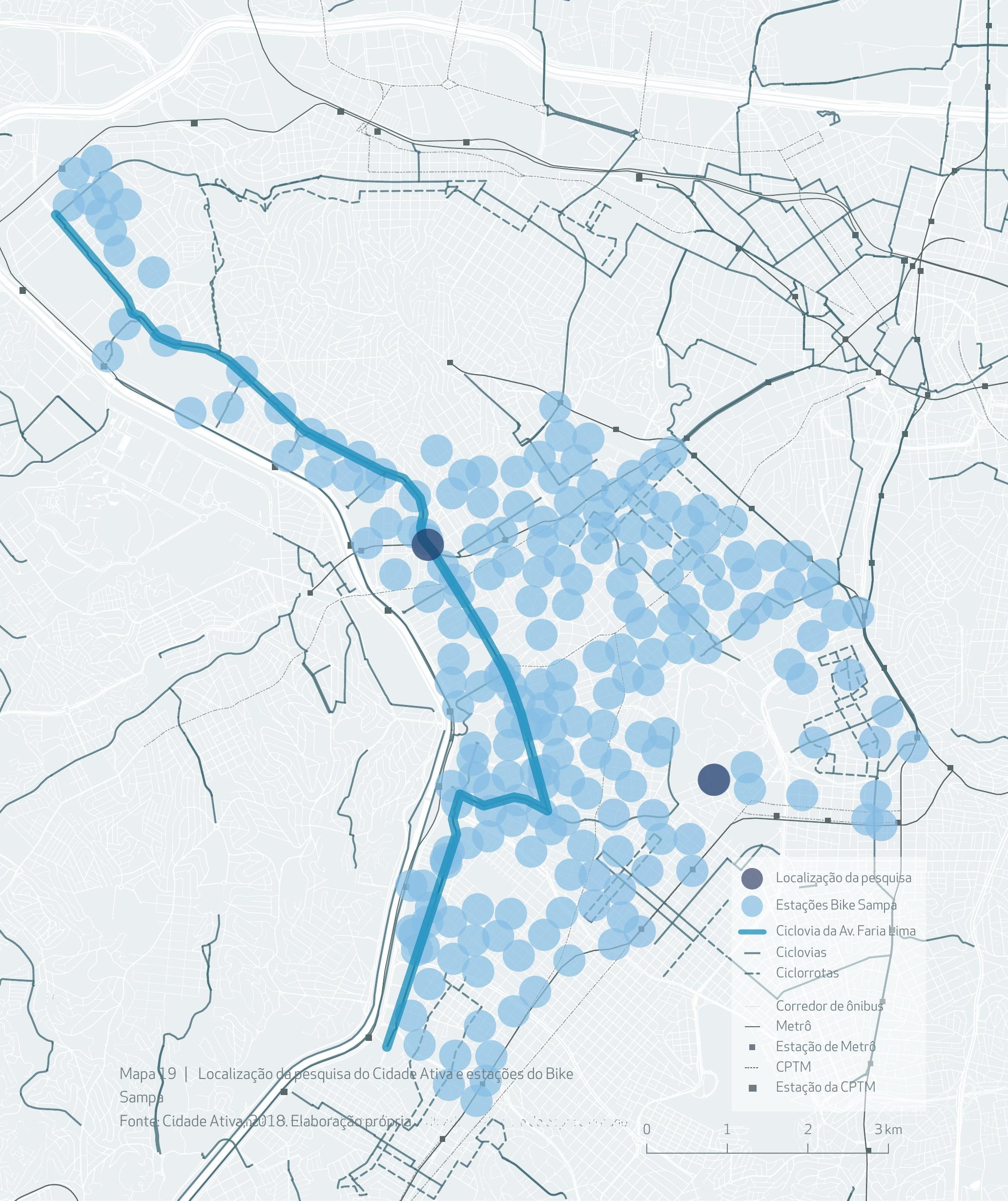


A metodologia dos painéis interativos foi desenvolvida pela Cidade Ativa para pesquisa em campo e funciona como ferramenta lúdica convidativa para a coleta de informaçôes, com o emprego de adesivos colados em um grande painel visível a todos. A amostra da presente pesquisa foi pontual e buscou abranger dois grupos distintos: o dos usuários e o dos năo usuários de bicicleta como meio de transporte, com foco no compartilhamento das bicicletas do Bike Sampa.

Devido à limitaçăo do número de respostas e do curto cronograma para o desenvolvimento da pesquisa interativa, a Cidade Ativa reforça que, por năo apresentar amostra ampla, o relatório serve apenas para avaliar as conclusôes baseadas no perfil e nos hábitos dos respondentes. Dessa forma, contribui para suscitar dúvidas e inquietaçôes a respeito do perfil encontrado, mas necessita de maior aprofundamento para adquirir consistência estatística.

Nem os entrevistados do Largo da Batata nem os do Parque Ibirapuera utilizavam a bicicleta como meio de transporte diário principal, mas gostariam, na maioria dos casos, de incorporá-la nos deslocamentos cotidianos. A falta de segurança no trânsito aparece como fator principal de impedimento de uso da bicicleta. Dos pesquisados, 61\% utilizam a bicicleta no dia a dia em substituiçăo ao transporte público, enquanto para $25 \%$ ela está no lugar do automóvel. 


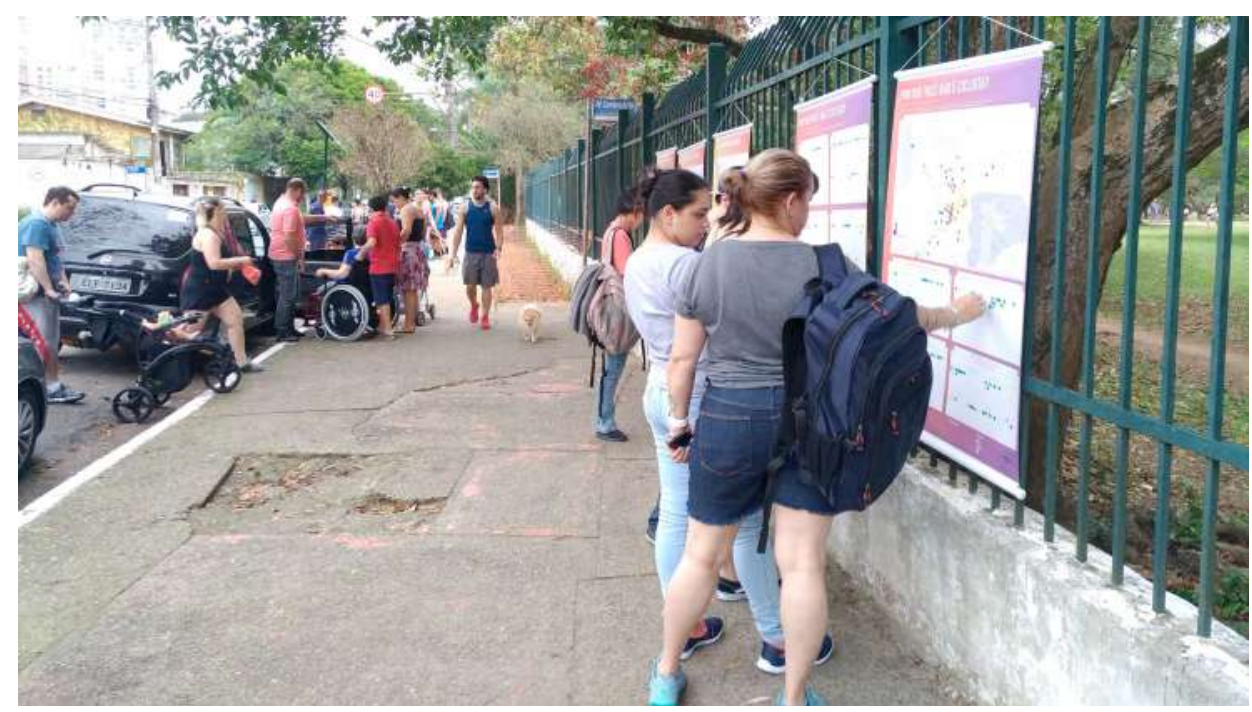

Foto 55 | Paineis interativos no Parque Ibirapuera

Fonte: Tembici. Cidade Ativa, 2018.

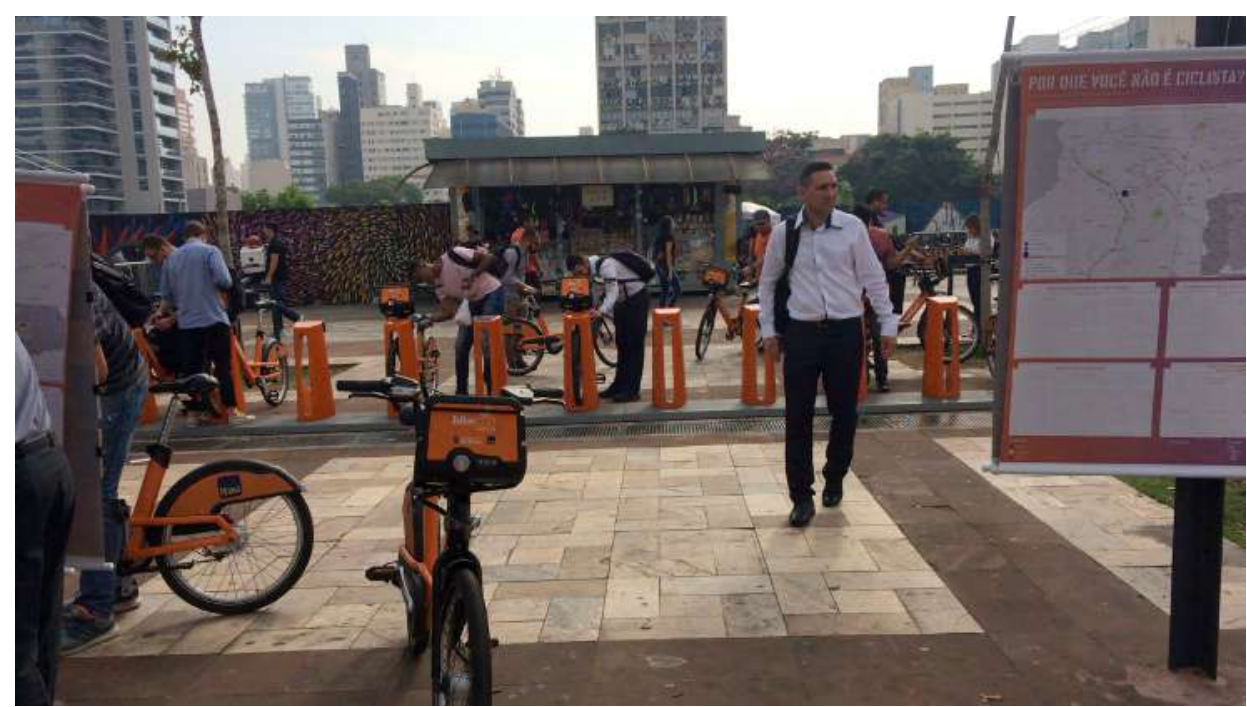

Foto 56 | Paineis interativos no Largo da Batata

Fonte: Tembici. Cidade Ativa, 2018. 


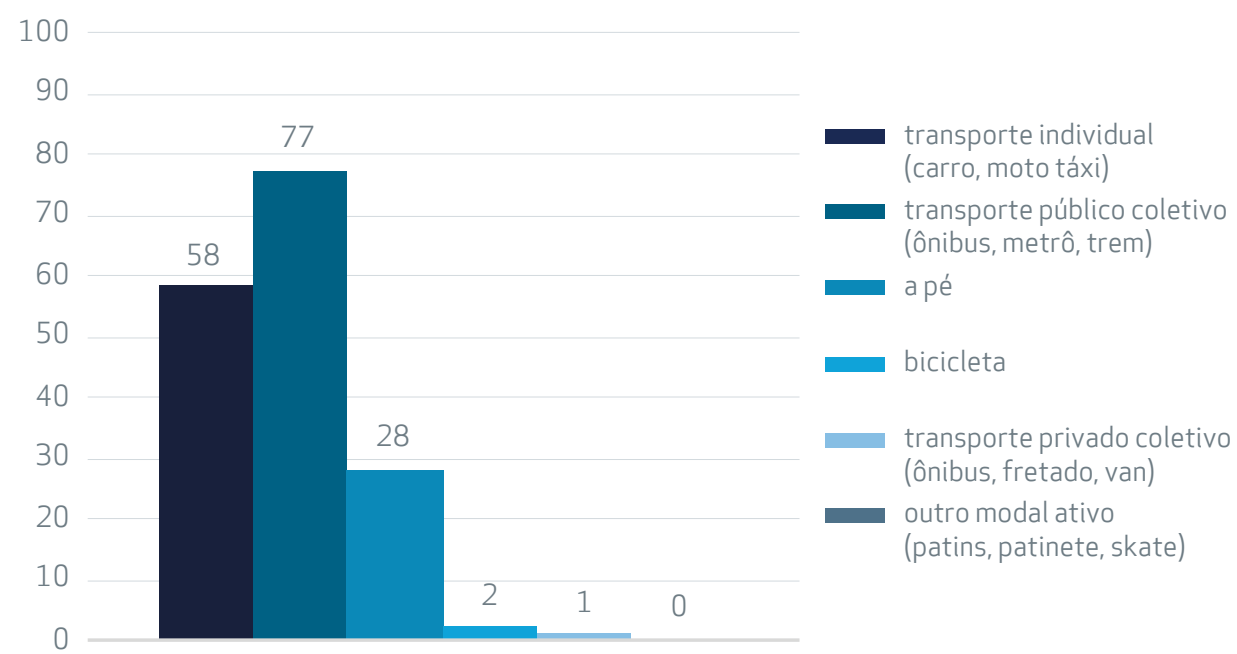

Gráfico 59 | Meio de transporte nos deslocamentos cotidianos Fonte: Tembici (Pesquisa realizada pela Cidade Ativa, 2018).

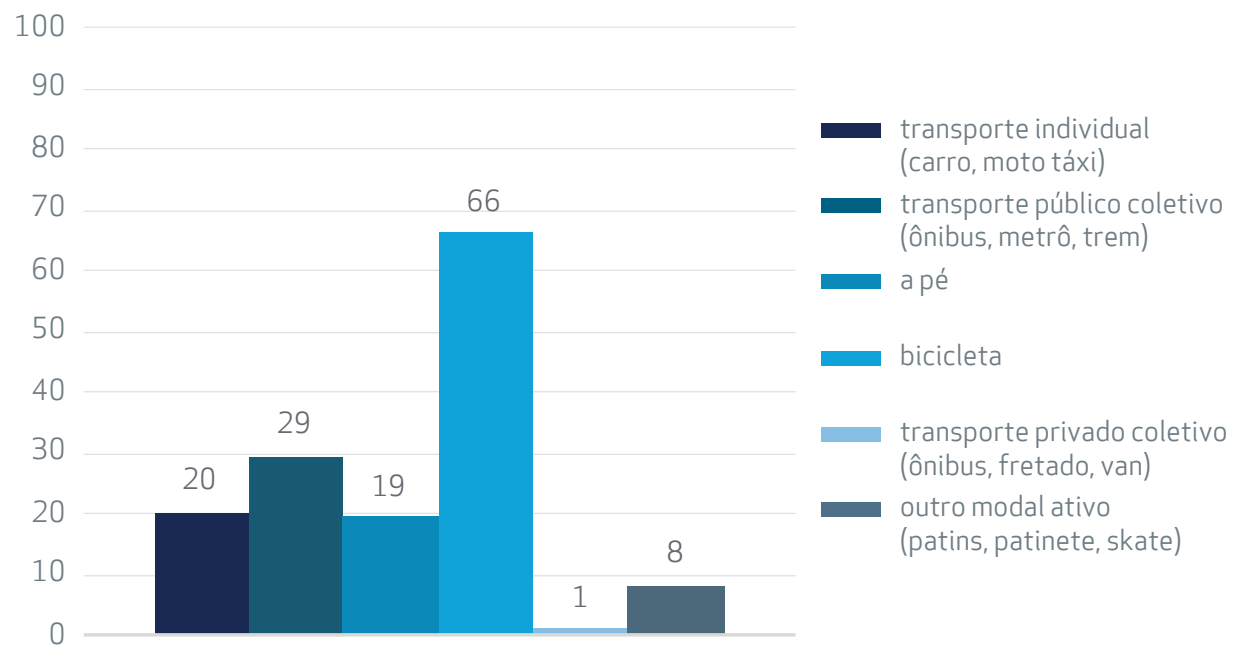

Gráfico 60 | Meio de transporte idealizado para os deslocamentos cotidianos Fonte: Tembici (Pesquisa realizada pela Cidade Ativa, 2018). 


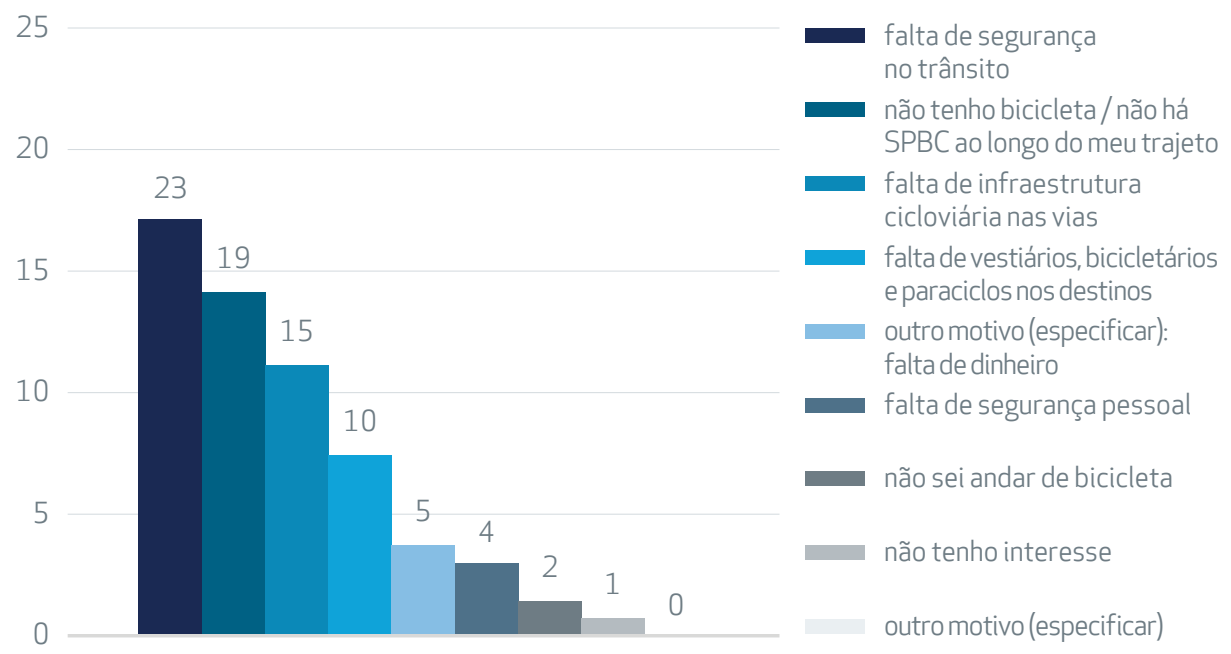

Gráfico 61 | Motivo para não utilizar a bicicleta no dia a dia Fonte: Tembici (Pesquisa realizada pela Cidade Ativa, 2018).

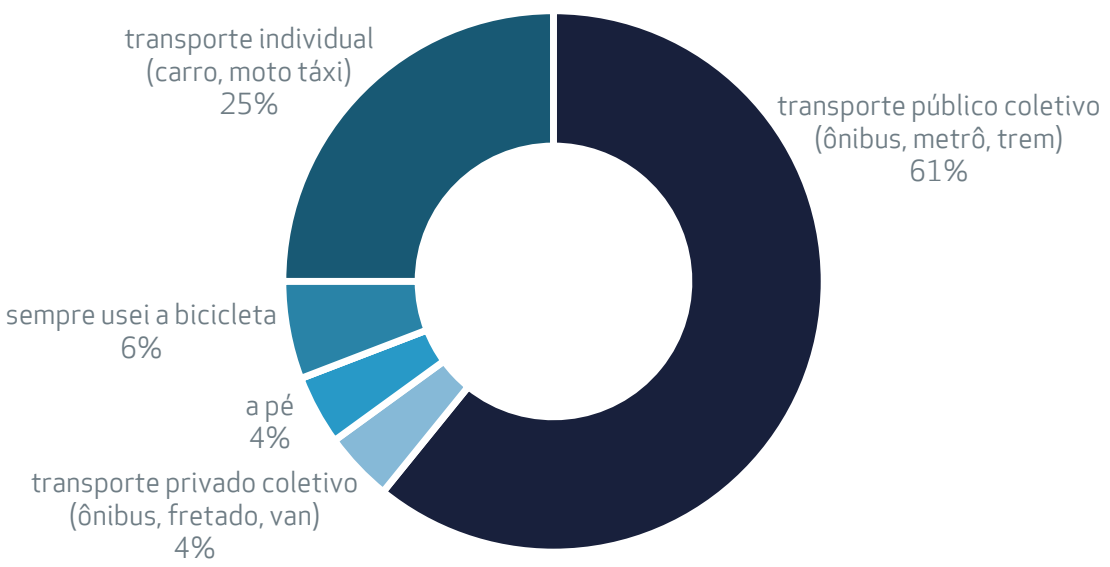

Gráfico 62 | Meio de transporte utilizado antes da bicicleta Fonte: Tembici (Pesquisa realizada pela Cidade Ativa, 2018). 


\subsection{Desafios do SPBC em São Paulo}

\section{Operacional}

A redistribuiçấo ou rebalanceamento das bicicletas nas estaçóes consiste em desafio para o sucesso do sistema de bicicletas compartilhadas nas cidades, de forma a assegurar que haverá bicicletas ou vagas quando necessário. DeMaio (2009) afirma que o transporte das bicicletas, feito pela operadora do sistema entre áreas de alta e baixa demanda, é trabalhoso, caro e poluente. Em horários de pico do uso do sistema, essa tarefa é fundamental, principalmente em cidades com deslocamentos pendulares desequilibrados, como Săo Paulo, na regiâo da Avenida Brigadeiro Faria Lima.

A ciclovia no canteiro central, que garante segurança aos ciclistas; a intermodalidade proveniente da estaçăo de metrô Faria Lima, no Largo da Batata, em maior volume, e nas estaçôes de trem da linha esmeralda da CPTM, amplificada pelo trânsito da avenida - que prejudica o último trecho da viagem feita tanto por automóvel, quanto por ônibus -, e a alta concentraçấo de empregos no eixo da avenida Berrini, Vila Olímpia, Itaim e Pinheiros contribuem para a forte presença dos modais ativos e em especial do SPBC Bike Sampa nessa regiâo.

Muitos usuários que migraram para a bicicleta compartilhada realizavam parte do trajeto de trem ou de ônibus. Segundo reportagem de Renata 
Falzoni ${ }^{33}$, do portal Bike é Legal, os entrevistados optaram pela bicicleta para garantir o percurso mais rápido que no modo anterior.

A estaçăo mais movimentada do Bike Sampa é a do Largo da Batata, com índice superior a 10\% das viagens totais do sistema. O bolsâo com capacidade para aproximadamente 500 unidades é uma das razōes que garantem a disponibilidade de bicicletas no pico de retiradas na parte da manhă para as pessoas que chegam de metrô na estaçăo Faria Lima e se preparam para o último trecho da viagem diária. Quando a procura é muito intensa e se esgotam as bicicletas, os usuários se organizam em fila para aguardar a chegada do veículo da logística com a reposiçăo (foto 57). É interessante verificar o comportamento do usuário, semelhante à espera comum nos pontos de ônibus da cidade.

33 Videorreportagem disponivel em: <https://www.youtube.com/watch?v=Q0TZc-VYFRs>. Acesso em: 27 jan. 2019. 


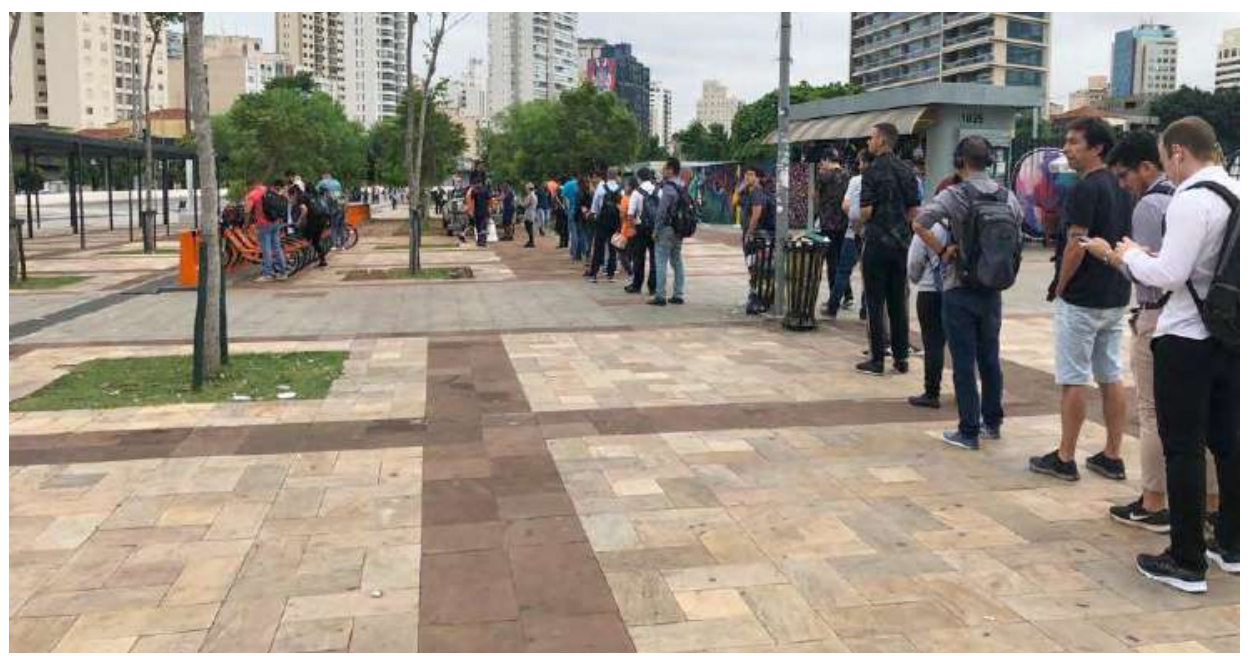

Foto 57 | Usuários aguardam a chegada de bicicletas na Estação 1 - Largo da Batata do Bike Sampa

Fonte: Débora Gonçalves, 5 fev. 2019, às 9h20.

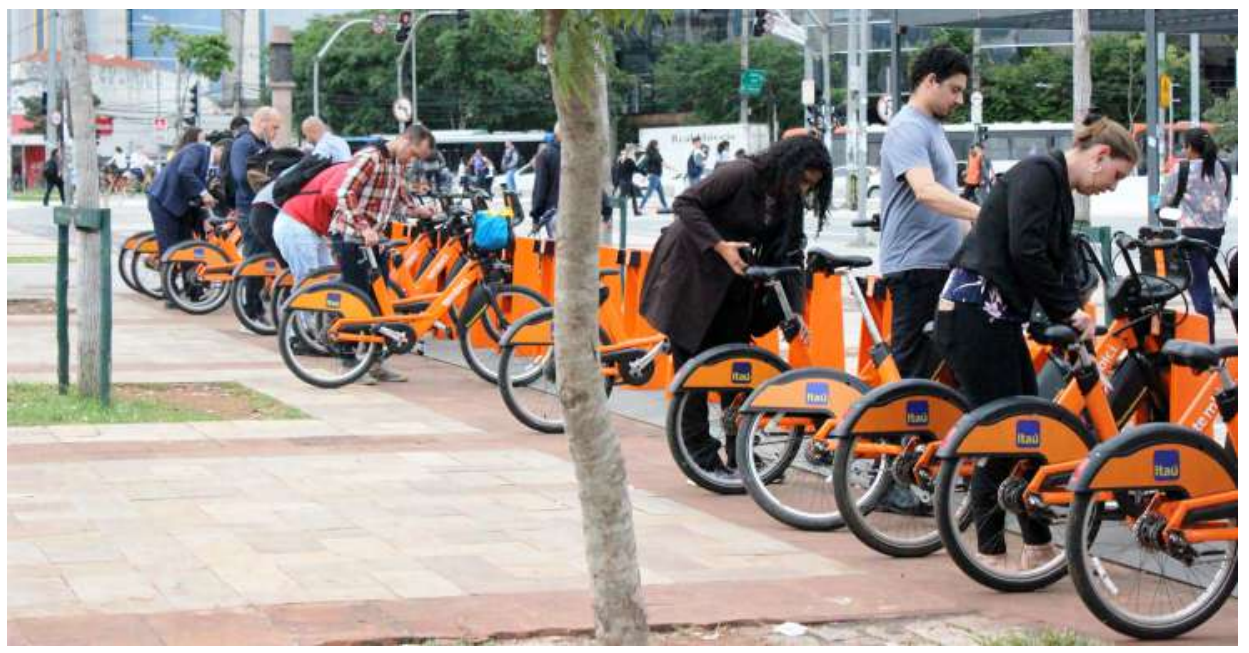

Foto 58 | Ciclistas retiram as bicicletas compartilhadas no período da manhã na estação 1 do Bike Sampa, próximo ao Metrô Faria Lima

Fonte: Luísa Cruz de Melo, em fevereiro de 2019. 


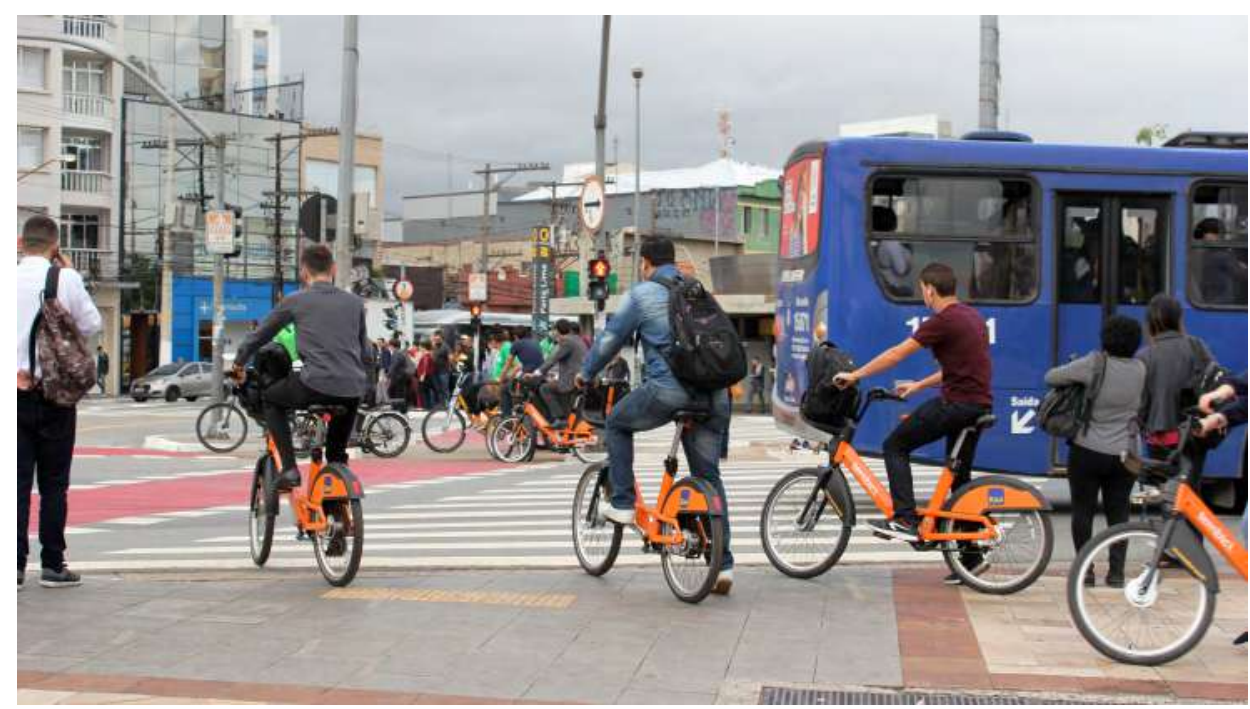

Foto 59 | Ciclistas aguardam abertura do semáforo do cruzamento da Avenida Brigadeiro Faria Lima e Rua Teodoro Sampaio, no período da manhã Fonte: Luísa Cruz de Melo, em fevereiro de 2019.

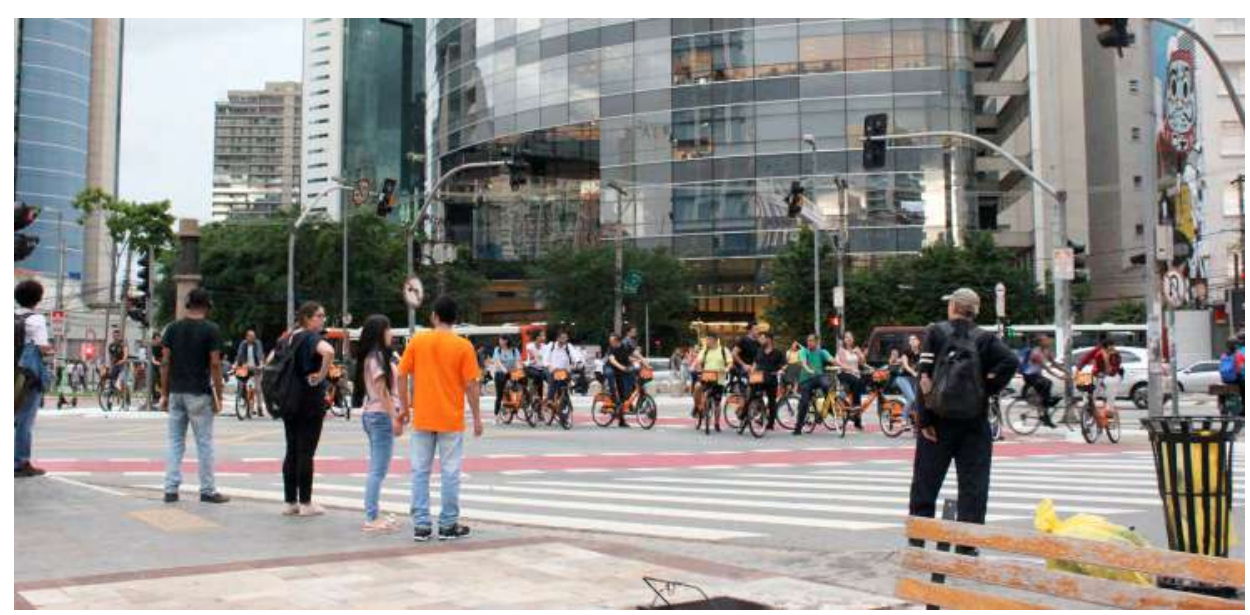

Foto 60 | Ciclistas aguardam a abertura do semáforo no cruzamento da Avenida Brigadeiro Faria Lima com a Rua Teodoro Sampaio, no final da tarde Fonte: Luísa Cruz de Melo, em fevereiro de 2019. 


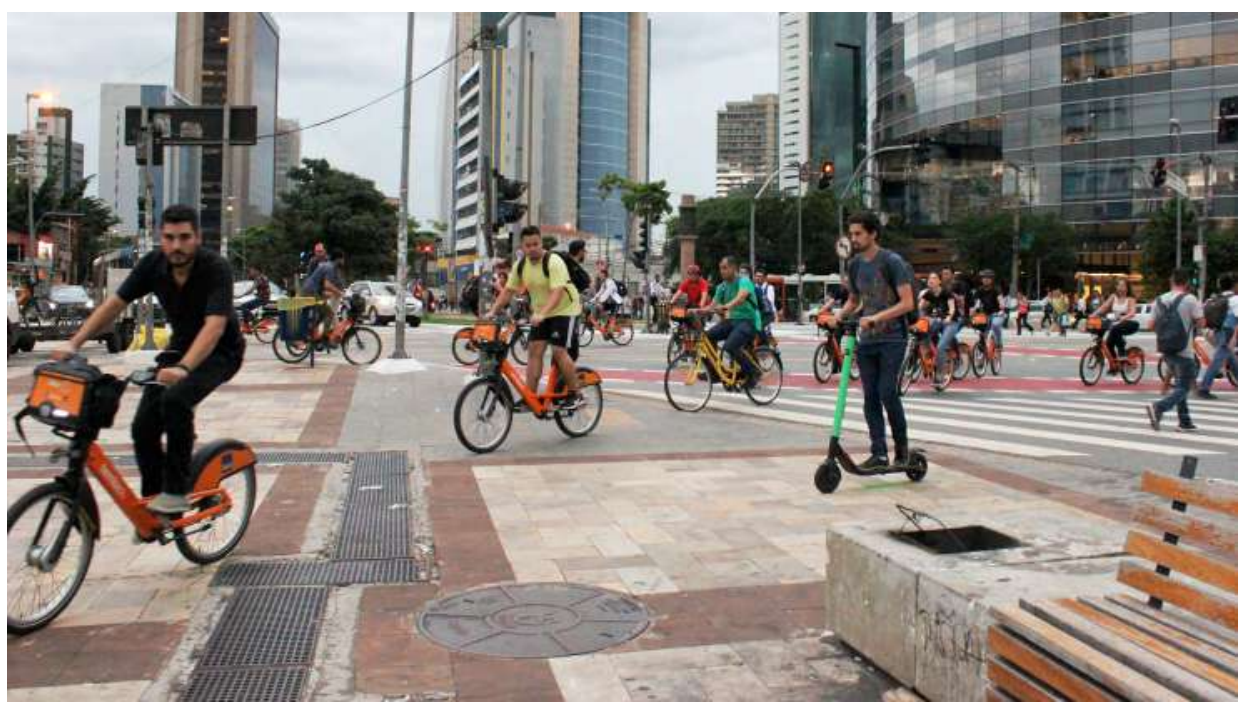

Foto 61 | Ciclistas atravessam o cruzamento da Avenida Brigadeiro Faria Lima com a Rua Teodoro Sampaio, em direção ao Metrô Faria Lima, no final da tarde Fonte: Luísa Cruz de Melo, em fevereiro de 2019.

De acordo com o relatório do Transporte Ativo (2018a) sobre a Oficina de Sistemas de Bicicletas Públicas, um dos desafios enfrentados pelos sistemas é a expansâo para regiôes metropolitanas das grandes cidades e a capacidade de tornar o uso acessível à populaçăo de baixa renda com a facilitaçăo dos meios de pagamento. Dados do sistema Bike Rio (Rio de Janeiro) e Bike Sampa (Săo Paulo) mostram que as estaçôes mais usadas sâo, respectivamente, a da Central do Brasil e a do Largo da Batata, próximas às estaçôes de trem e metrô, que atendem pessoas que chegam de regiōes periféricas da cidade. 


\section{Burocracia do poder público}

As açôes e definiçôes do poder público sâo muito lentas e năo acompanham a evoluçấo das novas tecnologias e nem usufruem das oportunidades. Assim, vemos bicicletas e patinetes elétricos dockless utilizados sem respeito às normas de uso do espaço público, conforme definidas no Estatuto do Pedestre (Lei $n^{\circ}$ 16.673/17).

Art. $3^{\circ}$ Todos os pedestres têm o direito à qualidade da paisagem visual, ao meio ambiente seguro e saudável, ao desenvolvimento sustentável da cidade, ao direito de ir e vir, de circular livremente a pé, com carrinhos de bebê ou em cadeiras de rodas, nas faixas de travessia sinalizadas das vias, nos passeios públicos, calçadas, praças e áreas públicas, sem obstáculos de qualquer natureza, assegurando-lhes segurança, mobilidade, acessibilidade e conforto, com a proteçăo em especial de crianças, pessoas com deficiência ou mobilidade reduzida e as da terceira idade.

Por um lado, é interessante vivenciar os espaços outrora ociosos ocupados por bicicletas e patinetes, e ver sua contribuiçăo com o aumento de uso desses modais ativos de deslocamento. No entanto, deve-se tomar cuidado para năo obstruir o caminho do pedestre nas calçadas. Para isso, considero a regulamentaçăo para organizaçăo dos equipamentos no espaço público importante para a perpetuidade dos sistemas.

Segundo Andrade e Rodrigues (2018), apesar de a bicicleta compartilhada se caracterizarem como serviço público de transporte, há pouca atuaçăo do Estado, tanto na regulamentaçâo quanto na fiscalizaçăo, de forma que a garantia da qualidade do serviço e da operaçăo ficam a cargo das empresas. 
“Da mesma maneira, sâo poucos os casos em que se notam subsídios do poder público à atividade, atuando no incentivo ao uso da bicicleta ou buscando tornar o sistema mais acessível por meio da reduçăo das tarifas" (ANDRADE; RODRIGUES, 2018, p. 71). Pode-se dizer, portanto, que a existência dos atuais sistemas seja fruto da iniciativa privada e que a atuaçâo do poder público ao incentivo do uso da bicicleta está concentrada na implantaçăo da infraestrutura cicloviária.

\section{Uso do espaço público}

O uso do espaço público pelos automóveis particulares está tăo enraizado no cotidiano das pessoas que ao confrontar essa condiçăo e substituir uma vaga de automóvel por diversas vagas de bicicletas de uma estaçăo de compartilhamento provocam-se indignaçăo e revolta imediatas. A experimentaçăo e o tempo sâo essenciais para que as pessoas se acostumem com o compartilhamento do leito carroçável com novas formas de ocupaçâo e contribuem para a convivência com essas soluçôes urbanas. 



\section{4. \\ Disputa \\ do espaço \\ urbano}

Provos teve papel importante quando se começou a perceber a importância da bicicleta compartilhada como deslocamento urbano, integrada com os demais modos de transporte público das cidades. Constant Nieuwenhuys ${ }^{1}$ critica as consequências da cultura do automóvel na sociedade e na cidade, nos documentos publicados em 1966, em Provo n9 (GUARNACCIA, 2010).

Nieuwenhuys discorre sobre a multiplicaçăo do número de carros e a contínua subtraçăo de espaço vital para dar lugar à circulaçăo e ao estacionamento dos veículos e critica o grande número de propriedades privadas em solo público. Diz que o código de trânsito priorizou o automóvel em detrimento do pedestre, tirou sua liberdade de acesso aos espaços públicos e revogou a principal funçăo da cidade, que é a de ser ponto de encontro.

\footnotetext{
É bastante significativo que a polícia justifique as medidas anti-happenings nos espaços públicos com a desculpa de que essas manifestaçôes impedem o trânsito. Esse é o reconhecimento implícito de que o verdadeiro dono da rua é o trânsito veloz (GUARNACCIA, 2010, p. 82)
}

Por fim, Nieuwenhuys explica que a luta dos jovens contra as regras se volta especialmente à reconquista da rua e diz que a ideia das bicicletas brancas é apenas o início de todo esse pensamento.

O projeto de SPBC năo trata apenas da questăo da mobilidade nas cidades, as mobilidades ativas, que podem substituir o automóvel ou o transporte público

1 Constant Nieuwenhuys foi pintor, escultor, artista gráfico, autor e músico holandês (19202005) e escreveu o Provo no 9. 
de maneira eficiente em trajetos de curta distância, até mesmo naqueles antes feitos a pé, o que contribui com a intermodalidade. Também toca no assunto muito importante do uso e do compartilhamento do espaço público, tanto por fomentar o aumento do número de ciclistas urbanos, que convivem nas ruas da cidade com outros modais, quanto por ocupar espaços para o estacionamento das bicicletas, até entâo disponíveis indiscutivelmente para os carros. É mais uma das açôes que colaboram para o convívio mais seguro e cordial dos diferentes usuários dos espaços livres do sistema viário.

Jannete Sadik-Khan, como chefe de transporte de Nova York na gestăo do Michael Bloomberg, passou pelo processo da implementaçấo do sistema de bicicletas compartilhadas, com seis mil bicicletas distribuídas em 330 estaçôes pela cidade, em 2013. Apesar de conduzir o processo participativo sobre a localizaçăo das estaçôes, tanto em reuniōes quanto em plataforma colaborativa digital, ela sabia da resistência que enfrentaria.

If a bike-share station was on the sidewalk, neighbors would protest that it impeded walking. If a station was in the street, bussinesses might bemoan a loss in parking for customers or deliveries. If it was in a park or plaza, there would always be someone to grumble about a loss of space for fun, art, or recreation ${ }^{2}$ (SADIK-KHAN, 2016, p. 195).

Em West Village, bairro de Nova York, moradores afirmaram que a estaçăo apresentava ameaça séria à segurança pública, com o argumento de que os

2 Se uma estação de bicicletas compartilhadas estivesse na calçada, vizinhos protestavam por ela atrapalhar o caminho do pedestre. Se a estação estivesse na rua, comércios reclamavam a perda da vaga de estacionamento para seus clientes e entregas. Se estivesse em um parque ou uma praça, sempre haveria alguém para reclamar sobre a perda de espaço para lazer, arte e recreação (tradução nossa). 
ciclistas andariam pela calçada. Eles abriram um processo para a remoçăo da estaçăo, que posteriormente foi arquivado. Desculpas diversas foram elaboradas, com processos abertos para solicitar a retirada, como as reclamaçóes referentes à estaçăo na frente de edifício residencial que bloqueava a chegada da ambulância para resgatar uma senhora de 92 anos; à estaçăo no local onde os residentes costumavam deixar o lixo; à estaçáo do outro lado da rua de um hotel, que reclamou da cor excessivamente azul das docas que atrapalhava a estética da edificaçâo, mas todas as demandas foram negadas.

Houve até comentário sobre a periculosidade do sistema devido ao terrorismo, pela possibilidade de se esconderem bombas nas bicicletas distribuídas por toda a cidade. No dia do lançamento do sistema, um jornalista escreveu que uma das estaçôes estava muito próxima de uma loja de bicicleta, e que competia com o negócio. Sadik-Khan revela que, dois anos depois do lançamento, quando escrevia seu livro, a loja ainda estava aberta, sem problemas financeiros.

Quando críticos também reclamaram que as estaçōes iriam violar o caráter histórico das ruas do bairro, blogs como o Brooklyn Spoke (GORDON, 2013) postaram imagens de carros abandonados estacionados nessas ruas, sem nenhuma reclamaçăo, e rebateram várias críticas negativas que estavam sendo recebidas. Sadik-Khan denota o papel da intervençâo na rua do sistema de bicicletas compartilhadas de demonstrar que as bicicletas e os ciclistas săo importantes, tăo parte da rua quanto ônibus e automóveis, que atualmente a dominam. 
Bike share carries the rewriting of the streets to its full potential, using its infrastructure as an intervention that changes the street and helps achieve more expansive goals. The presence of hundreds of stations sent the message that bikes and the people who ride them are importante and as much a part of the streets and the city's transportation network as the buses or cars that dominate them ${ }^{3}$ (SAKID-KHAN, 2016, p. 202-203).

Quanto mais ciclistas nas ruas, maior a demanda por infraestrutura cicloviária, mais pessoas sâo atraídas para pedalar, o que deixa as vias mais seguras, contribuindo para o ciclo virtuoso.

More riders create demand for more biking infrastructure and invite more people to ride and to walk on increasingly safer streets in an increasingly virtuous cicle. Seen this way, bike share was transformative transportation for New Yorkers, not just getting them from place to place but bringing more of the city and its streets within reach of

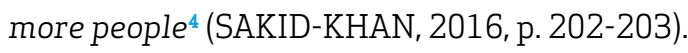

Além disso, o sistema de bicicletas compartilhadas ajuda a quebrar a cultura de que a rua é apenas para os veículos motorizados ao trazer mais ciclistas

3 O sistema de bicicleta compartilhada carrega o redesenho das ruas em seu potencial completo e utiliza sua infraestrutura como intervenção que modifica a rua e ajuda a alcançar objetivos maiores. A presença de centenas de estações envia a mensagem de que as bicicletas e as pessoas que as pedalam são importantes e fazem tanto parte das ruas e da malha de transporte da cidade quanto ônibus e automóveis que as dominam (tradução nossa).

4 Mais ciclistas criam a demanda para mais infraestrutura cicloviária e convidam mais pessoas a pedalar e caminhar em ruas mais seguras, criando o ciclo virtuoso. Dessa forma, o sistema de bicicletas compartilhadas foi um sistema de transporte transformador para os Nova lorquinos, não apenas por deslocá-los de um ponto a outro, mas por trazer mais da cidade e das suas ruas ao alcance de mais pessoas (tradução nossa). 
para disputar e dividir o espaço das vias. A rede de estaçóes modifica a linguagem da rua e, dessa forma, a paisagem política.

And bike share is a physical, irrefutable alteration of the city, breaking the bike-brain barrier that makes people think that streets can never be wrested back from the combustion engine. The ubiquity of bike share changes the need that people have for the street. (...) The network of stations changed the language of the street, and with it the entire political landscape ${ }^{5}$ (SAKID-KHAN, 2016, p. 204).

Segundo o ITDP (2017c), a viagem de automóvel sempre começa e termina em vaga de estacionamento. Portanto, a disponibilidade de vagas é um fator determinante na decisâo sobre o modo de transporte escolhido na realizaçăo da viagem. "A sobreoferta de vagas de baixo custo induz o uso do transporte individual motorizado e suas consequências, como congestionamentos, número de colisôes e emissâo de poluentes" (ITDP, 2017c, p. 4).

No século XX, com o crescimento da demanda pelos espaços ocupados por carros estacionados, praças e calçadas usadas pelos pedestres foram convertidas em estacionamento. Dessa forma, o movimento inverso, iniciado no século XXI, de retirar vagas de estacionamento para devolver o espaço a pedestres e ciclistas é avaliado pelas pessoas como uma açăo que proíbe e dificulta o deslocamento feito com o automóvel, o que causa indignaçâo.

5 E o compartilhamento de bicicletas é uma alteração física e irrefutável da cidade, quebrando a barreira que faz as pessoas pensarem que as ruas nunca podem ser recuperadas do motor de combustão. A onipresença do compartilhamento de bicicletas muda a necessidade que as pessoas têm pela rua. (...) A rede de estações mudou a linguagem da rua, e com ela toda a paisagem política (tradução nossa). 
Nas cidades brasileiras, as reclamaçóes săo semelhantes, pois estamos passando pelo processo da disputa do espaço do carro, frente à transformaçăo de vagas de estacionamento em estaçôes de bicicletas compartilhadas.

Diversas notícias desse período de instalaçăo das estaçóes revelam o interesse das pessoas pela novidade e demonstram sua aceitaçâo, apesar de o projeto sofrer reclamaçóes porque as estaçôes passaram a ocupar espaços na cidade, principalmente quando estăo nos leitos carroçáveis e retiram vagas de estacionamento de veículos. Em 2015, reportagem do jornal 0 Globo, do Rio de Janeiro, relata a polêmica na Zona Sul da cidade, quando o espaço antes ocupado por três carros foi substituído pela estaçăo de doze vagas de bicicleta compartilhada. Uma moradora do edifício em frente da estaçâo comenta: "Agora nâo temos como parar na porta de casa quando chegamos com compras, malas... A Rua Sorocaba é estreita e ficou ainda pior para os carros" (COSTA, 2015). Mas outras pessoas comemoraram a instalaçăo dessa estaçâo, por possibilitar o acesso à bicicleta de quem chega do metrô Botafogo, o que viabiliza a integraçâo modal. Gustavo Almeida, coordenador de controle de concessōes da Secretaria Especial de Concessōes e Parcerias Público-Provadas afirmou, em 2015:

A nossa prioridade é deixar a calçada livre para os pedestres, usando as vagas de estacionamento. A bicicleta é um transporte compartilhado por um grande número de pessoas, enquanto o carro tem uso individual. Queremos que cada vez mais pessoas usem o transporte coletivo. Os embates que estâo ocorrendo sâo naturais, mas os usuários das bicicletas vêm aplaudindo as soluçôes.

Numa reportagem do Globo de maio de 2018, Gilberto Porcidonio apresenta a polêmica da localizaçăo das estaçôes de bicicletas compartilhadas. 0 
presidente da Associaçâo de Moradores e Amigos do bairro no Leme, Francisco Nunes, disse em entrevista: "Somos a favor da utilizaçăo da ciclovia e das bicicletas, mas em local adequado. A estaçăo tinha que ser na orla ou no calçadăo central, nâo dentro do bairro. Onde está, fica até difícil pegar a bicicleta para ir à ciclovia" (PORCIDONIO, 2018).

Podem-se perceber algumas convicçôes em sua fala, como o entendimento de que a bicicleta é utilizada apenas para lazer, e năo para transporte, quando diz que as estaçôes deveriam encontrar-se apenas na orla e năo dentro do bairro. Para garantir o papel da bicicleta como transporte, é essencial que haja estaçôes em todos os lugares de maneira a permitir opçôes de origem e destino por toda a área de cobertura do sistema, seja na orla, seja dentro do bairro. Outro ponto apresentado foi o desconhecimento de que o ciclista tem o direito de compartilhar a via com os veículos motorizados, aspecto que se destaca quando Porcidonio menciona a dificuldade de acesso à ciclovia como impedimento para a instalaçâo da estaçáo naquele local. Nunes denota a visăo do protagonismo do automóvel no uso do espaço público, ao dizer que uma das estaçôes do bairro "tomava o espaço de cinco vagas de carro, o que é inadmissível".

No caso das dificuldades de implementaçâo do sistema Bike Rio, atestadas pelas reclamaçōes de parte da populaçăo pelo fato de as estaçōes substituírem vagas de automóvel particular, Clarisse Linke (2018), diretora do ITDP, evidencia a dependência aos carros e a opçăo feita por parte da prefeitura por retirar ou reposicionar as estaçôes nas calçadas sem consultar os setores técnicos: "Năo é razoável optar por três carros em detrimento de dezenove bicicletas, que podem ser usadas por dezenas de pessoas a cada hora". 
Derrubar o fetiche pelo carro, símbolo máximo de status do século XX, pode nos levar a dias melhores, mas năo apenas no que se refere a uma mobilidade mais sustentável. É preciso criar modos mais sustentáveis de negociar com o coletivo, e isso requer pôr em xeque todo este individualismo (LINKE, 2018).

Nas cidades brasileiras, a hegemonia do carro ainda está presente, tanto na atitude da populaçăo, conforme discutido anteriormente, quanto na postura do poder público, por concordar ou simplesmente nâo se posicionar frente às discussōes sobre o assunto.

Como exemplo de envolvimento positivo do poder público, cito a Cidade do México, onde há o fomento do uso de modos de transporte que tragam benefícios aos usuários e que necessitem de menos espaço físico para locomoçâo.

La transformación actual de las ciudades busca generar espacios que promuevan una cultura de movilidad sustentable (...). En los últimos años se ha invertido en integrar una red de infraestructura ciclista, garantizar la accesibilidad a bicicletas y sobre todo incidir en el cambio del paradigma cultural, con el objetivo de fomentar el uso de modos de transporte que requieran menos espacio, pero que maximicen benefícios ${ }^{6}$ (CDMX,2017, p.12).

6 A atual transformação das cidades busca gerar espaços que promovam uma cultura de mobilidade sustentável (...). Nos últimos anos investiu-se na integração de uma rede de infraestrutura cicloviária, para garantir a acessibilidade às bicicletas e, sobretudo, influenciar a mudança do paradigma cultural, com o objetivo de incentivar o uso de modos de transporte que exigem menos espaço, mas que maximizam beneficios. (Tradução nossa). 
Transformar a maior aglomeraçâo urbana da América do Norte em cidade ciclista é um grande desafio e significa promover melhores condiçōes urbanas e de convivência social, segundo o Departamento de Cultura, Desenho e Infraestrutura Ciclista da Secretaria do Meio Ambiente (SEDEMA) da Cidade do México.

Em 2007, a Cidade do México deu início a um programa da Secretaria de Meio Ambiente chamado Muévete en Bici Mova-se em bicicleta (traduçăo nossa) em que ruas e avenidas utilizadas normalmente para o transporte motorizado sâo transformadas em grandes calçadōes, aos domingos, para pedestres, ciclistas, patinadores, skatistas, corredores, de forma a permitir que as pessoas desfrutem das ruas, espaços públicos por excelência, para a recreaçăo, a fomentar a atividade física e a convivência social e a promover a experimentaçăo da cidade de maneiras diferentes.

Esse programa tem o objetivo de democratizar o espaço público e transformar a visấo da cidade e a cultura de mobilidade focada nos modos ativos de deslocamento, ao permitir aos cidadāos assumirem que a rua, antes de ser espaço de trânsito e circulaçâo de automóveis, caracteriza-se, sobretudo, como lugar de vida.

A vontade política é fundamental para incentivar o uso da bicicleta. $\mathrm{Na}$ Cidade do México há o trabalho engajado do poder público que visa a garantir a permanência da bicicleta como elemento fundamental para a sustentabilidade e a mobilidade através do estímulo desse modo de transporte como política pública. De 2008 a 2016, houve crescimento de 496\% no número de viagens por bicicleta da cidade, o que demonstra que a vontade do governo de fomentar o ciclismo urbano, em conjunto com o esforço dos 
grupos de ciclistas e cicloativistas, traz resultados perceptíveis na qualidade de vida dos cidadăos (CDMX,2017).

\subsection{Reclamações}

No decorrer da instalaçăo das estaçōes dos sistemas brasileiros, foram recebidas diversas reclamaçōes no Serviço de Atendimento ao Consumidor (SAC) da Tembici, no SAC do patrocinador (Itaú), na ouvidoria das subprefeituras da cidade de Sâo Paulo e nas redes sociais. Algumas delas sâo descritas a seguir.

_SAC Itaú sobre Bike Sampa (2018)

A pessoa informou que a estaçâo de bicicleta ocupa muitas vagas e que năo é bonita para ficar na frente de seu prédio, pois as bicicletas sâo laranja (Itaim Bibi, Săo Paulo, SP).

_SAC Itaú sobre Bike Sampa (2018)

Reclamaçâo da instalaçâo do ponto de bicicletas do Itaú em frente ao prédio em que reside situado no Itaim Bibi. $O$ cidadăo informou que a instalaçấo ainda nâo foi concluída, diz que a situaçâo está causando transtorno e que tem incomodado os moradores do entorno. Alega que os moradores năo foram consultados e exigiu formalizar que năo concorda e que exige providência. 
_SAC Tembici sobre Bike Sampa (2018)

O reclamante diz que năo acredita que aquele seja o local mais adequado para a instalaçăo dessa estaçăo, pois já năo há vaga para estacionamento dos veículos dos moradores. Completa informando que nas redondezas é possível encontrar local mais apropriado, com mais visibilidade para que as pessoas possam utilizar as bicicletas.

_SAC Tembici sobre Bike Rio (2018)

A pessoa solicita a retirada do bicicletário instalado na Vila Isabel, com os argumentos de que a rua tem măo dupla, que os moradores da rua e adjacências têm dificuldade para estacionar e que foram ocupadas duas vagas de automóveis. Diz ainda que as ruas săo estreitas e năo comportam uma estaçăo de bicicleta. Informa que já existem outras estaçôes perto do local que poderiam ser usadas.

_SAC Tembici sobre Bike Sampa (2018)

O indivíduo reclama que foi instalada uma estaçăo na área de comerciantes e revela que todos estăo insatisfeitos e revoltados (supermercado, sebo e restaurante), pois já há falta de estacionamento perto. Ela gostaria de um remanejamento para a praça próxima e informou que já existe um abaixo -assinado protocolado na prefeitura. Menciona também que se năo houver resoluçăo vai trancar as bicicletas com corrente (foto 62). 
_SAC Tembici e Itaú sobre Bike Sampa (2018)

$O$ sujeito queixou-se de que a estaçấo de bicicletas foi instalada em frente à garagem que será construída na reforma de sua residência. A estaçăo foi deslocada para liberar o espaço solicitado, porém nova ligaçăo foi feita para informar que a măe do reclamante é deficiente e năo conseguiria entrar em casa, pois a estaçấo estava na frente da porta de acesso de pedestres, e sugeriu que fosse colocada do outro lado da rua, na frente da casa de seu vizinho. Como năo foi possível alterar o endereço da estaçăo devido à autorizaçâo do poder público, a estaçâo permaneceu no local. Em seguida, o reclamante ligou novamente para dizer que sua máe estava com pânico e medo de sair de casa, pois a estaçăo lhe trazia insegurança.

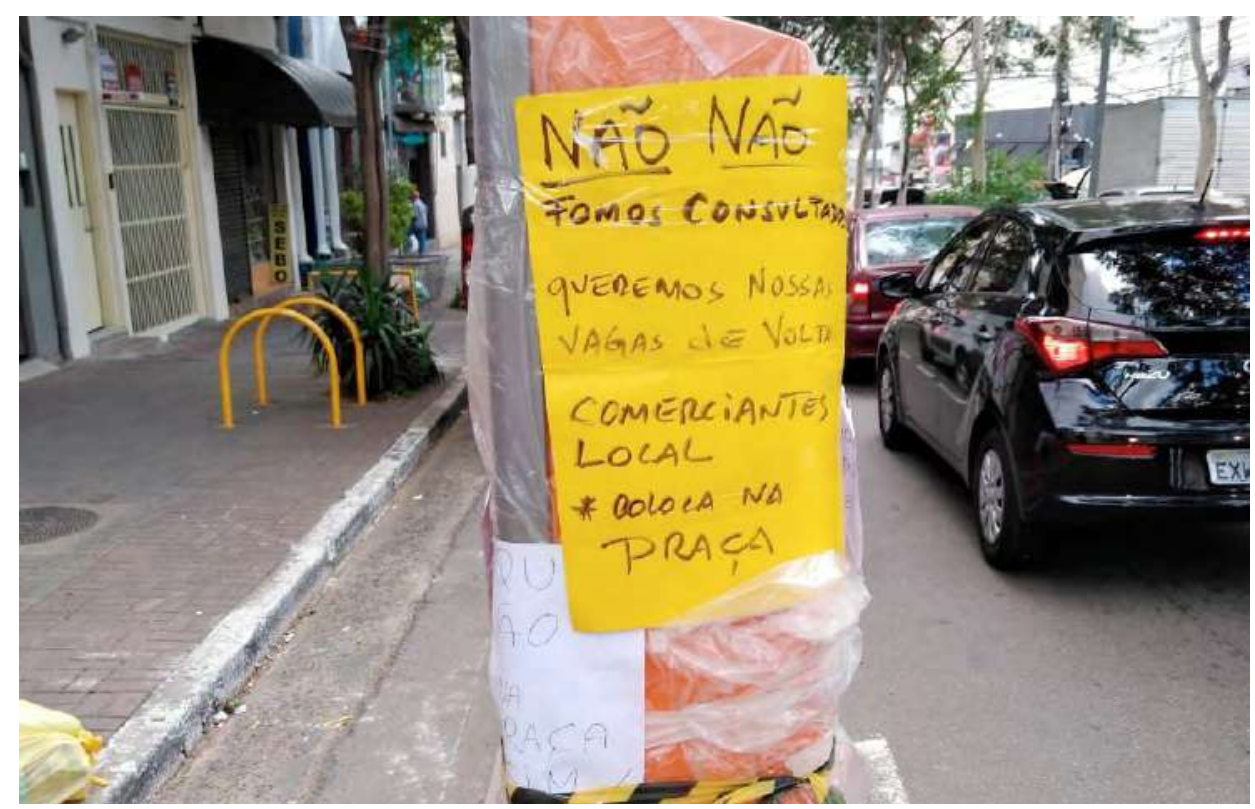

Foto 62 | Foto dos cartazes de reclamação colados pelos comerciantes na estação de bicicletas compartilhadas (dezembro de 2018)

Fonte: Tembici (2018). 
_Folha de S.Paulo, 25 de dezembro de 2018

"Surpreso e pasmo com a quantidade de bicicletários instalados em movimentados pontos da cidade, onde deveria haver vagas de zona azul para a populaçăo. Essas instalaçóes sâo do interesse do contribuinte? Quanto paga o banco que explora esses bicicletários para utilizar o espaço público? Mário Sérgio Guidio Salzstein (figura 17).

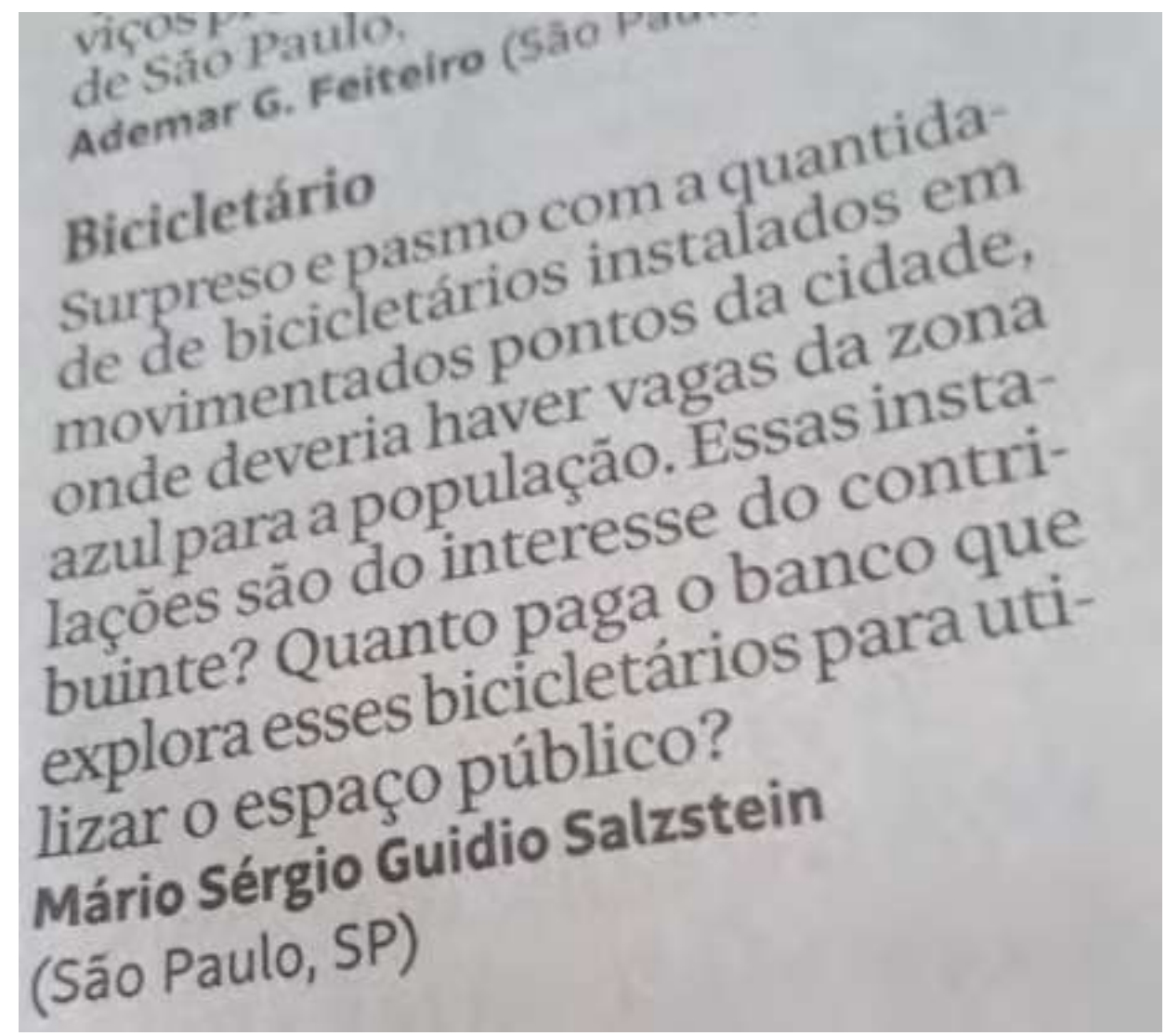

Figura 17 | Reclamação de paulistano sobre a estação Bike Sampa 
_SAC Tembici sobre Bike Rio (2019)

O indivíduo diz que o projeto é excelente, só que foi instalado na rua, e năo na calçada como todas as demais estaçôes, e por isso traz desagrado e transtorno aos ocupantes dos prédios, pois retirou quatro vagas dos moradores, que năo possuem garagem.

_SAC Itaú sobre Bike Rio (2019)

O cliente informa que no Rio de Janeiro a instalaçăo dos suportes de bicicleta está ocupando vagas de veículos, o que denigre a imagem do banco, pois isso acontece em várias ruas e avenidas.

_SAC Tembici sobre Bike Sampa (2019)

Reclamaçăo sobre a concentraçăo de nove estaçóes na Vila Leopoldina e a ocupaçăo de vagas de carro dos moradores da regiăo.

_SAC Itaú sobre Bike Sampa (2019)

O cliente năo concorda com a instalaçăo das bicicletas na porta da sua casa, pois vários idosos precisam do espaço para descer do carro e as bicicletas atrapalham, diz que gosta do conceito do uso das bicicletas, que a prática é importante para a sociedade, mas que elas deveriam ser posicionadas mais próximas ao metrô. 
_SAC Itaú sobre Bike Sampa (2019)

A estaçáo de bicicletas colocada em frente de dois prédios residenciais traz transtorno com o barulho da manutençáo, bem como das pessoas que retiram as bicicletas e ficam conversando embaixo da janela onde residem idosos e crianças, o que causa constrangimentos, acorda os moradores em horários de silêncio, uma verdadeira falta de respeito. Além disso, estranhos ficam bem na frente do prédio, o que provoca falta de segurança.

_Bike Sampa (2019)

Sugestâo de remoçăo da estaçăo para o interior da Praça Ernani Braga, sem prejudicar o fluxo de carros que param diariamente na esquina por causa do farol.

Como demonstrado na foto 63 , as estaçôes, quando postas no leito carroçável, localizam-se em vagas de estacionamento e náo na faixa de rolamento. Portanto, mesmo se a estaçấo fosse retirada, o fluxo dos carros nessa faixa permaneceria inexistente, pela presença de automóveis estacionados. $O$ interessante é haver esse tipo de reclamaçăo quando no local existe a estaçáo de bicicleta e năo quando os carros estáo estacionados. Acredito que as pessoas estejam mais acostumadas com a presença da ocupaçăo desse espaço pelos automóveis e năo pelas bicicletas. 

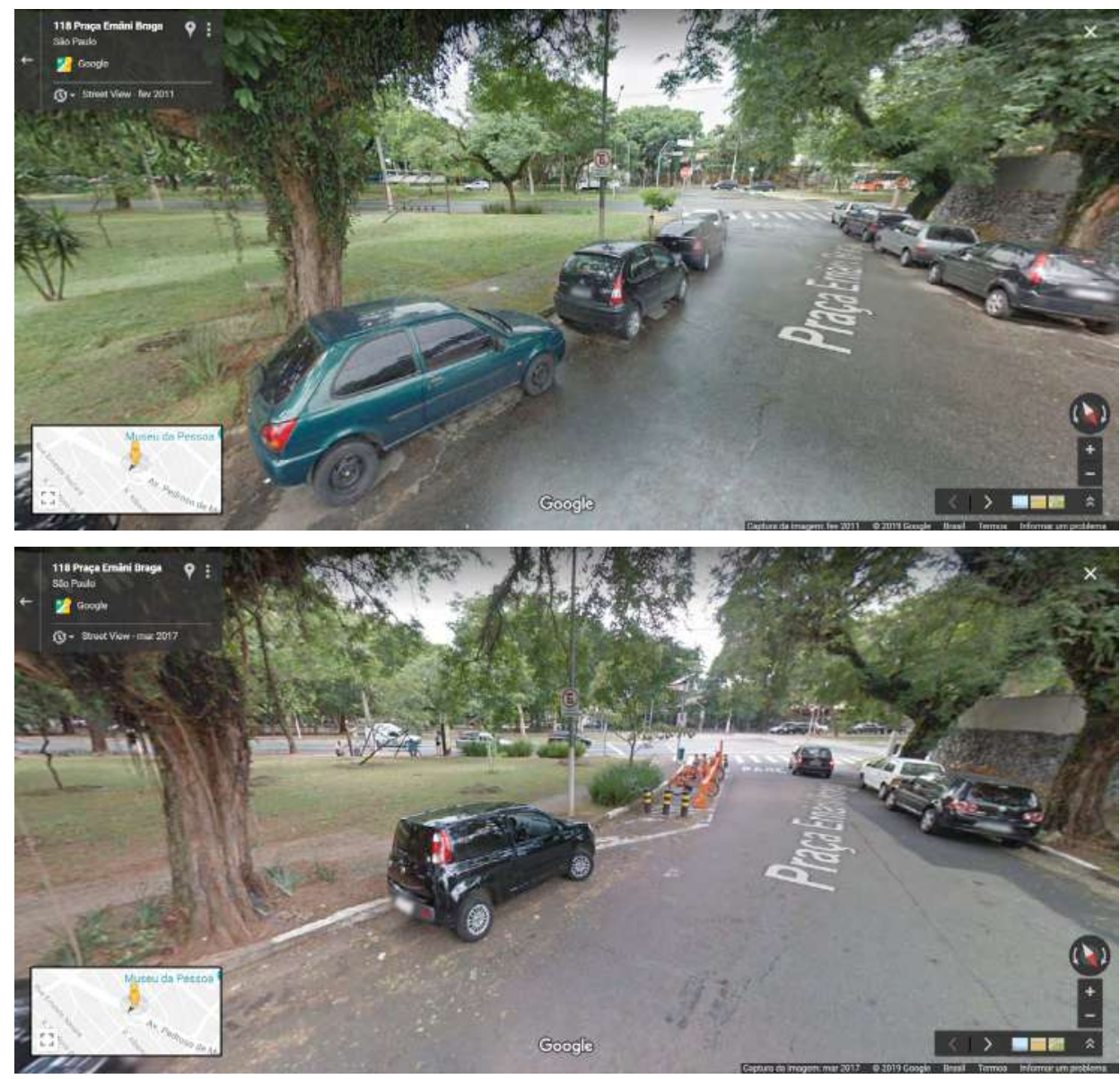

Foto 63 | Praça Ernani Braga (São Paulo), em 2011 e 2017 Fonte: Google Street View, em 2011 e em 2017.

A maior parte das reclamaçôes diz respeito à perda de vagas de estacionamento de moradores da regiấo ou de clientes, quando a estaçăo se localiza próximo de lotes comerciais. O entendimento de que aquele espaço é de uso exclusivo dos automóveis particulares é unânime, e o inconformismo e a agressividade nas reclamaçôes estâo sempre presentes. 
As contestaçóes revelam o incômodo gerado pela retirada do espaço do automóvel, e o entendimento de muitas pessoas de que esse espaço é de sua propriedade. Năo houve processo participativo para a escolha de cada ponto das estaçóes de bicicletas compartilhadas, apenas a consulta a cicloativistas a respeito da área de cobertura, além do trabalho de urbanistas e engenheiros que analisaram a cidade, fizeram a previsăo da demanda para determinar a quantidade de vagas e desenvolveram os projetos, conforme os Critérios de Sinalizaçăo de Estaçăo de Bicicletas Compartilhadas da CET. Acredito que se houvesse o processo participativo, grande parte das pessoas que compareceriam às atividades se posicionariam contra as estaçôes, e a implantaçâo seria inviabilizada.

Houve também reclamaçôes feitas fora dos canais de atendimento, por vereadores, por exemplo, e que infelizmente sempre tiveram êxito em forçar a rápida retirada da estaçăo, sem nenhum argumento técnico, simplesmente pelo fato de que ela ocupava espaço anteriormente utilizado pelo automóvel. Isso aconteceu principalmente nas cidades de Sáo Paulo e do Rio de Janeiro, e demonstra o jogo de poder de forças políticas, que tomam decisōes para benefício próprio sem argumentaçăo técnica.

A subprefeitura de Pinheiros da cidade Sáo Paulo, na Oficina realizada no Rio de Janeiro sobre sistemas de bicicleta compartilhada, em outubro de 2018 (TRANSPORTE ATIVO, 2018a), informou que a associaçăo do bairro solicitou a retirada de uma estaçáo de Alto de Pinheiros com o argumento de que năo acreditava na necessidade de bicicletas naquela regiăo, pois os moradores do bairro năo as usariam, por já terem a própria bicicleta. Completaram com a reclamaçâo de que pessoas de Osasco (município 
vizinho, da Regiâo Metropolitana de Săo Paulo) iriam até aquela área para usar as bicicletas e que isso nâo seria interessante para eles.

A posiçâo da subprefeitura foi manter a estaçâo no local, pois năo foram apresentados argumentos plausíveis para a relocaçăo dessa estaçăo. 0 Departamento de Modos Ativos (DPM) da CET, porém, năo aprovou o projeto da estaçăo, por ter recebido essa mesma reclamaçăo da associaçăo de bairro, e solicitou sua relocaçăo, mesmo năo havendo nenhum problema com o projeto de sinalizaçấo da estaçấo nem de posicionamento de trânsito.

\subsection{Crises recentes na mobilidade das cidades}

A greve dos caminhoneiros no Brasil, que ocorreu entre 20 e 31 de maio de 2018, possibilitou um experimento informal excepcional para a análise da mudança da qualidade do ar em funçâo da imobibilidade veicular no país. Segundo o relatório produzido pelo Instituto Saúde e Sustentabilidade, em que se estudou o material particulado e o ozônio monitorados em estaçōes automáticas entre 21 de maio e $1^{\circ}$ de junho no Estado de Săo Paulo, observou-se decréscimo de até $\mathbf{7 8 \%}$ da concentraçăo de poluentes.

“Segundo o Instituto Saúde e Sustentabilidade, a poluiçăo atmosférica é responsável por 17 mil mortes e 4.700 mortes ao ano, respectivamente, no Estado e na cidade de Sâo Paulo" (VORMITTAG; DELGADO, 2018, p.28). Durante a greve, os níveis de concentraçăo de poluentes estiveram dentro dos parâmetros considerados seguros para a saúde da populaçâo pela Organizaçăo Mundial de Saúde (OMS). 
A bicicleta surgiu como possibilidade frente ao cenário caótico que se instaurou nas cidades com a falta de combustível e a reduçăo da frota de ônibus. O contador da ciclovia da Avenida Brigadeiro Faria Lima acusou o recorde de viagens em 29 de maio (gráfico 63), com 7.591 viagens.

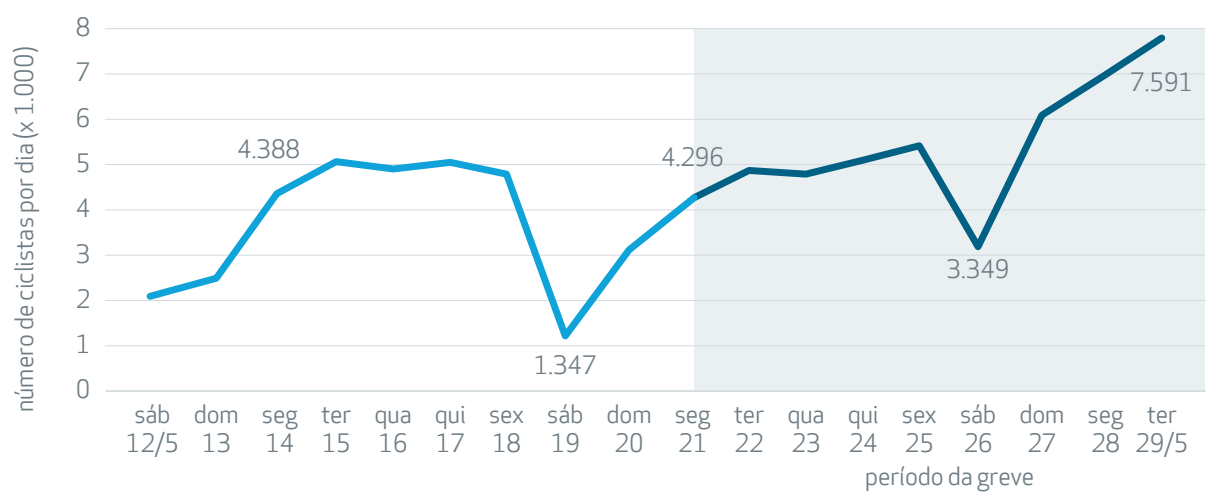

Gráfico 63 | Número de ciclistas por dia que foram contabilizados no Contador de ciclistas da Avenida Brigadeiro Faria Lima

Fonte: Reis (2018). Infográfico feito em: 30 de maio de 2018 pelo G1. Elaboração própria.

No gráfico 64 identifica-se o pico de uso da ciclovia da Avenida Brigadeiro Faria Lima em maio de 2018, e os sucessivos recordes de uso a partir de setembro do mesmo ano, contabilizando, em 4 de dezembro de 2018, 8.936 passagens.

É visível o aumento da ocupaçăo desse espaço e da adoçăo de modos ativos de deslocamento no dia a dia. Nas últimas semanas do ano e no início de janeiro de 2019, época de férias coletivas em muitas empresas e férias escolares, houve queda acentuada do número de ciclistas na ciclovia. Mais um argumento de que os modos ativos estăo sendo utilizados como transporte com a finalidade de ida ao trabalho, e năo apenas como lazer. 


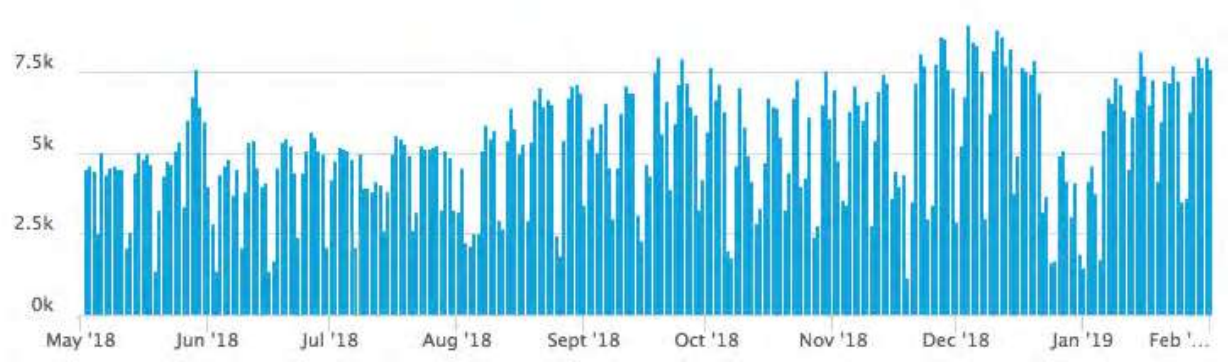

Gráfico 64 | Número de ciclistas por dia que foram contabilizados no contador de ciclistas da Avenida Brigadeiro Faria Lima de $1^{\circ}$ de maio de 2018 a 31 de janeiro de 2019

Fonte: Contador Faria Lima (desenvolvido por http://www.eco-compteur.com/pt/).

A greve dos caminhoneiros também acarretou o aumento do número de viagens de bicicletas compartilhadas em todas as cidades. 0 gráfico 65 mostra o pico de uso em 29 de maio de 2018 do sistema Bike Sampa. Em pesquisas qualitativas com usuários do sistema de bicicletas compartilhadas de Sáo Paulo, muitas pessoas afirmaram que começaram a utilizar a bicicleta compartilhada diariamente após esse período. Essa situaçâo atípica de crise na cidade propiciou a experimentaçâo de maneiras alternativas de deslocamento, que, eventualmente, foram incorporadas ao cotidiano das pessoas. 


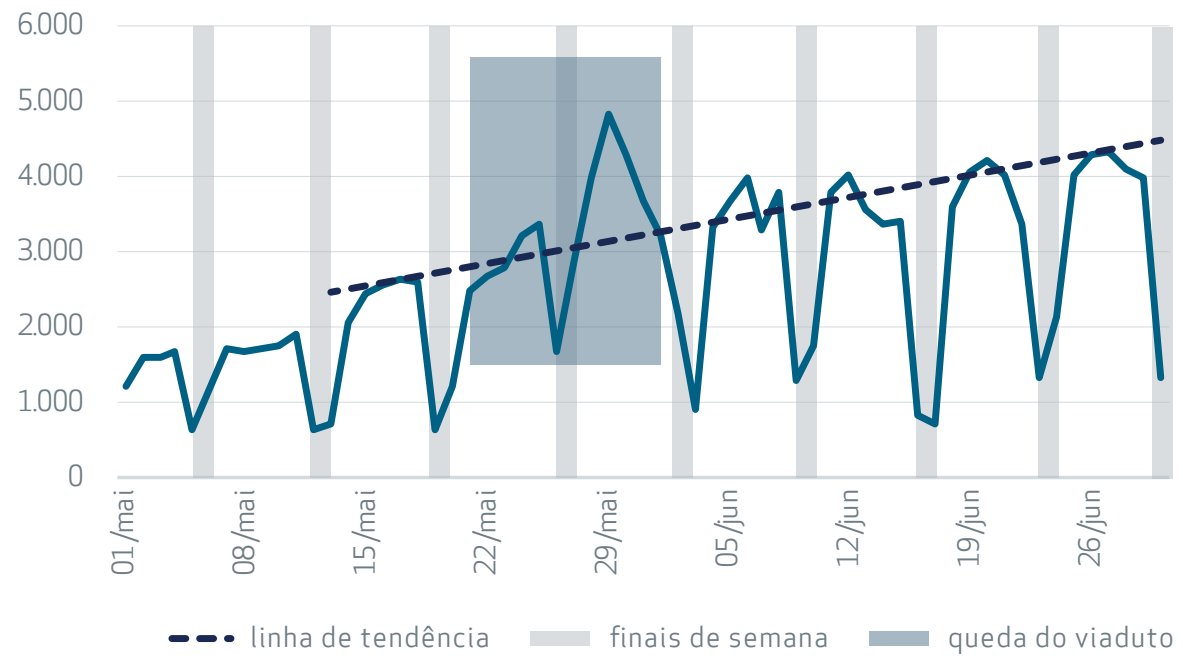

Gráfico 65 | Viagens por dia no Bike Sampa entre 1º de maio de 2018 e 30 de junho de 2018 Fonte: Tembici. Elaboração própria.

Outro exemplo de crise no trânsito da cidade de Săo Paulo foi causado pela queda do viaduto na Zona Oeste, o que contribuiu para mais um debate sobre o papel da bicicleta na mobilidade urbana. A Prefeitura de Săo Paulo criou o comitê de crise de pontes e viadutos com o Decreto n 58.516, de 19 de novembro de 2018, que viabilizou a autorizaçăo para a instalaçăo das estaçôes de bicicleta compartilhada pelas subprefeituras.

As autorizaçōes foram publicadas em Diário Oficial das seguintes subprefeituras: Pinheiros (8/12/2018), Santo Amaro (8/12/2018), Lapa (11/12/2018) e Vila Mariana (24/01/2019), e permitiram às empresas credenciadas como OTTC: 
instalar bicicletas, com ou sem estaçâo física, em caráter, extraordinário, temporário e a título precário, nos espaços públicos listados no Anexo I, como forma emergencial de minimizar o impacto dos efeitos gerados pela interdiçâo do viaduto que cedeu cerca de dois metros na madrugada de 15.11.2018, na regiăo do Jaguaré, na Zona Oeste de Săo Paulo, o que levou à interdiçăo da Marginal Pinheiros sentido Rodovia Castelo Branco.

Dessa forma, năo houve burocracia nem demora para a instalaçăo das estaçôes, e todo o processo da autorizaçăo formal pela CET e da emissâo da TPU pelas subprefeituras aconteceu após a instalaçâo e a verificaçáo da aceitaçâo da estaçăo pelas pessoas da regiăo. Isso possibilitou a experimentaçấo das estaçôes e do uso da bicicleta, o que pode colaborar para a mudança de hábito e de opiniấo de pessoas que inicialmente eram contrárias à ideia de ter uma estaçăo de bicicleta no espaço de vagas de estacionamento.

\subsection{Urbanismo tático}

Urbanismo tático é a terminologia atualmente utilizada para designar todas as açōes realizadas nos espaços urbanos com intento de estabelecer condiçôes de diálogo, negociaçăo e experimentaçăo, com vistas a mudanças físicas ou gerenciais mais duradouras. Para tanto, utiliza açôes e projetos de rápida implementaçăo, reversíveis e de baixo custo e tem o grande objetivo de demonstrar o potencial de mudanças a longo prazo, eventualmente transformando-se em política pública. O propósito geral de todas as açôes de mobilidade ativa e outras tantas intervençôes e políticas públicas consiste em propiciar a animaçăo e reapropriaçáo do espaço urbano pelas pessoas. 
Qualquer proposta de mudança na organizaçăo ou na configuraçăo de espaços livres públicos demanda complexa negociaçăo com os vários agentes públicos e privados envolvidos. Tal negociaçăo é dificultada por ideias e práticas estabelecidas, receios e resistências sem fundamentos. Uma maneira de enfrentar essas dificuldades é sugerir testes temporários, experimentaçôes que permitam a todos os agentes e usuários avaliar as vantagens e os problemas do novo arranjo.

Açôes igualmente temporárias e estratégicas já podem ser identificadas na história da arquitetura e do urbanismo. Nas últimas décadas tais práticas têm sido mais frequentemente empregadas por técnicos e por grupos organizados para ampliar e qualificar as discussōes acerca das propostas de intervençâo dos espaços públicos. 0 termo urbanismo tático evidencia essas práticas e destaca suas vantagens e contribuiçôes.

Segundo Pacheco (2014), as áreas ociosas, por se converterem em espaços públicos de convivência, concorrem para a qualidade de vida das pessoas.

Ao conferir novos sentidos para os lugares a partir de mudanças rápidas, o urbanismo tático cria cidades mais amigáveis aos moradores e, muitas vezes, motiva as pessoas a repensarem seus hábitos por meio dos diferentes encontros e trocas que esses espaços possibilitam.

No bairro de Santana, na Zona Norte de Sáo Paulo, foi realizada uma intervençăo temporária em 16 de setembro de 2017 pelo ITDP Brasil, em parceria com a Iniciativa Bloomberg para Segurança Global no Trânsito (BIGRS), a Iniciativa Global de Desenho de Cidades (NACTO-GDCI), o WRI Brasil Cidades Sustentáveis, a Vital Strategies, a CET-SP e a Prefeitura Regional Santana Tucuruvi. “A açăo teve como objetivo sensibilizar a populaçăo 
para a questăo da segurança viária e chamar a atençăo do poder público, que pode realizar medidas concretas de requalificaçăo do espaço urbano" (PREFEITURA DE SÃO PAULO, 2017).

Segundo o Relatório de Atividade do ITDP Brasil (2018) “Intervençăo urbana temporária: (re)pensando a rua em Santana", as intervençōes temporárias, também conhecidas como uma forma de urbanismo tático, têm como intuito transformar o espaço urbano de maneira rápida e barata, para possibilitar testar soluçôes que viabilizem o processo de transformaçăo permanente. Dessa forma, tanto a populaçăo quanto o poder público ganham a oportunidade de vivenciar a transformaçăo da rua, com aumento da segurança de pedestres, o que contribui para a nova experiência no espaço urbano.

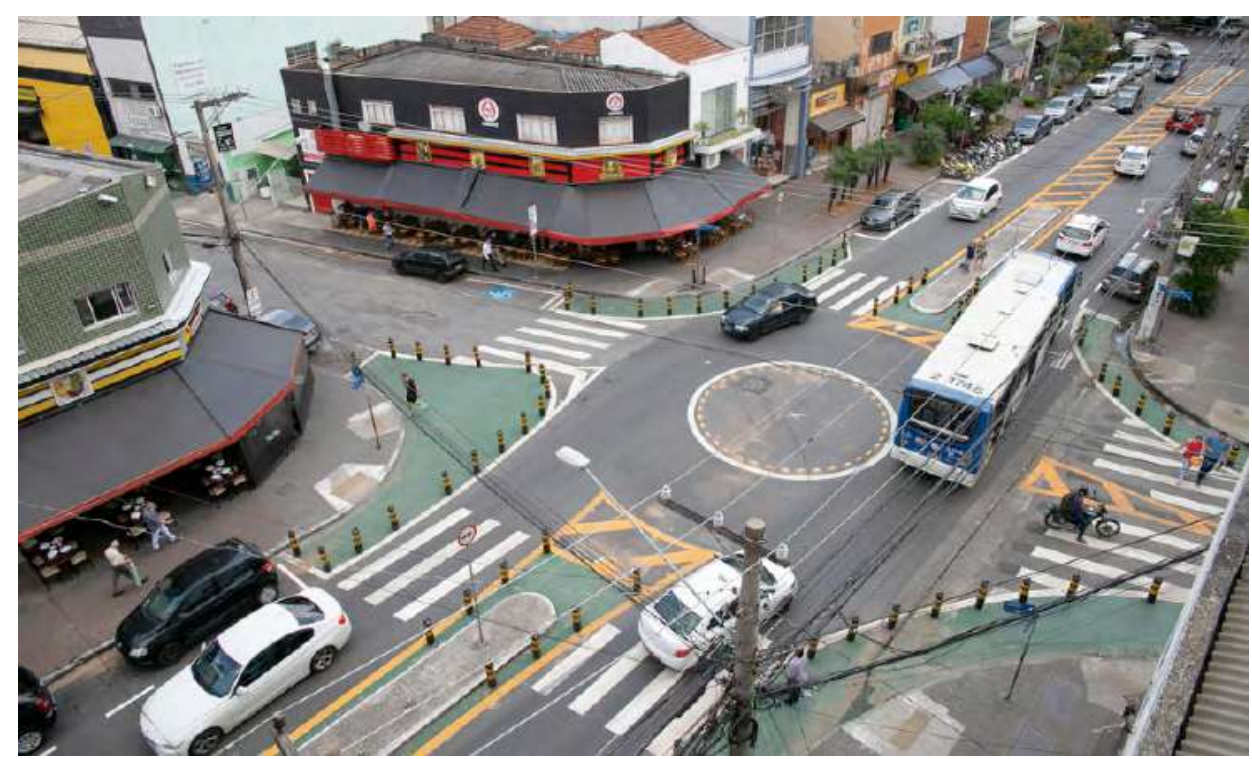

Foto 64 | Intervenção em cruzamento do bairro de Santana consolidada pela CET Fonte: Joana Oliveira/WRI Brasil (outubro de 2018) 

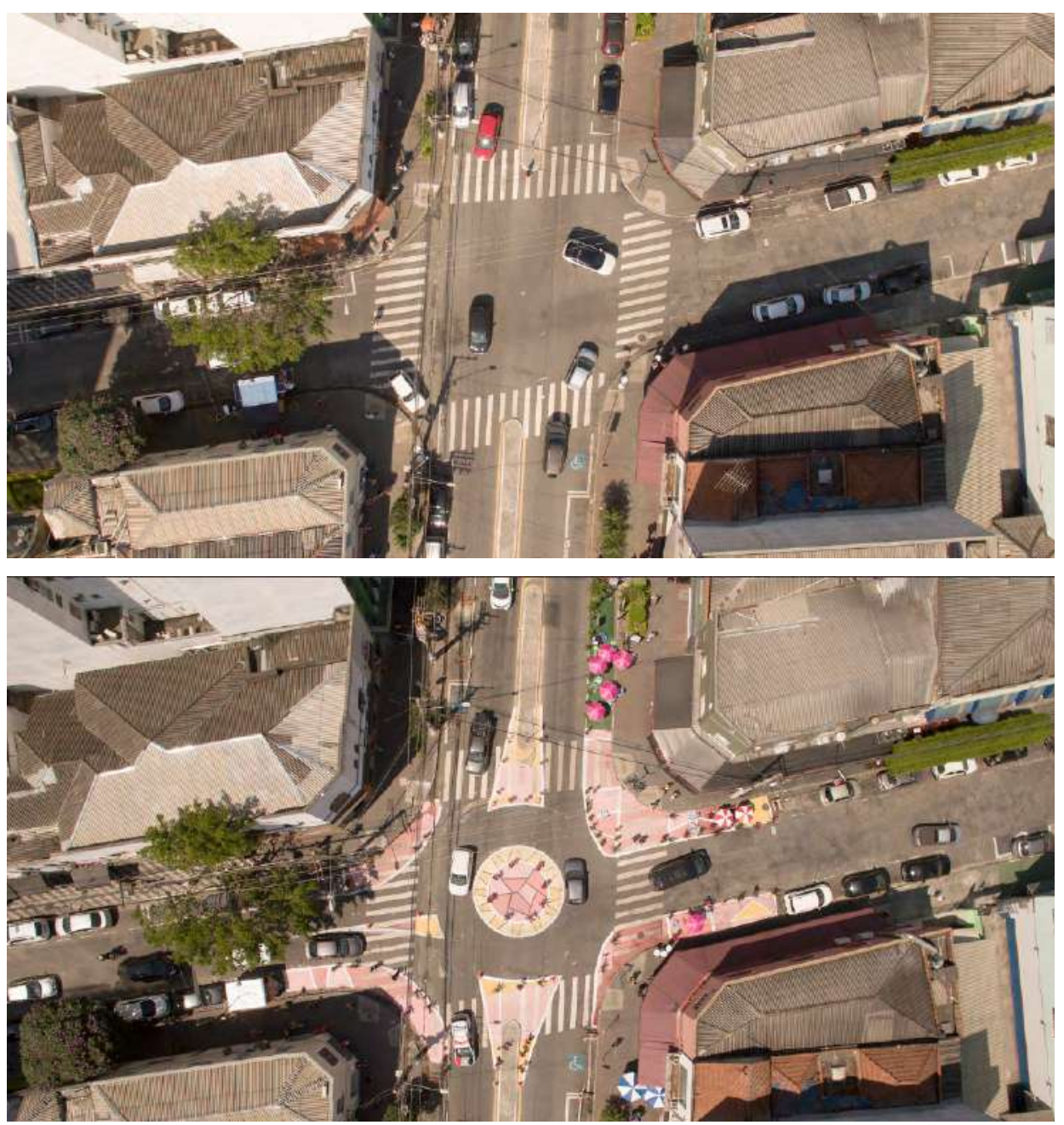

Foto 65 | Cruzamento de Santana antes e depois da intervenção viária Fonte: Victor Moriyama/WRI Brasil (setembro de 2017)

O alto índice de aprovaçăo das medidas implantadas auxiliou a implementaçăo do projeto permanente de segurança viária pela Prefeitura de Săo Paulo, em junho de 2018 (MARQUES, 2018). 
Alguns outros exemplos de açôes de urbanismo tático exitosas săo descritos a seguir.

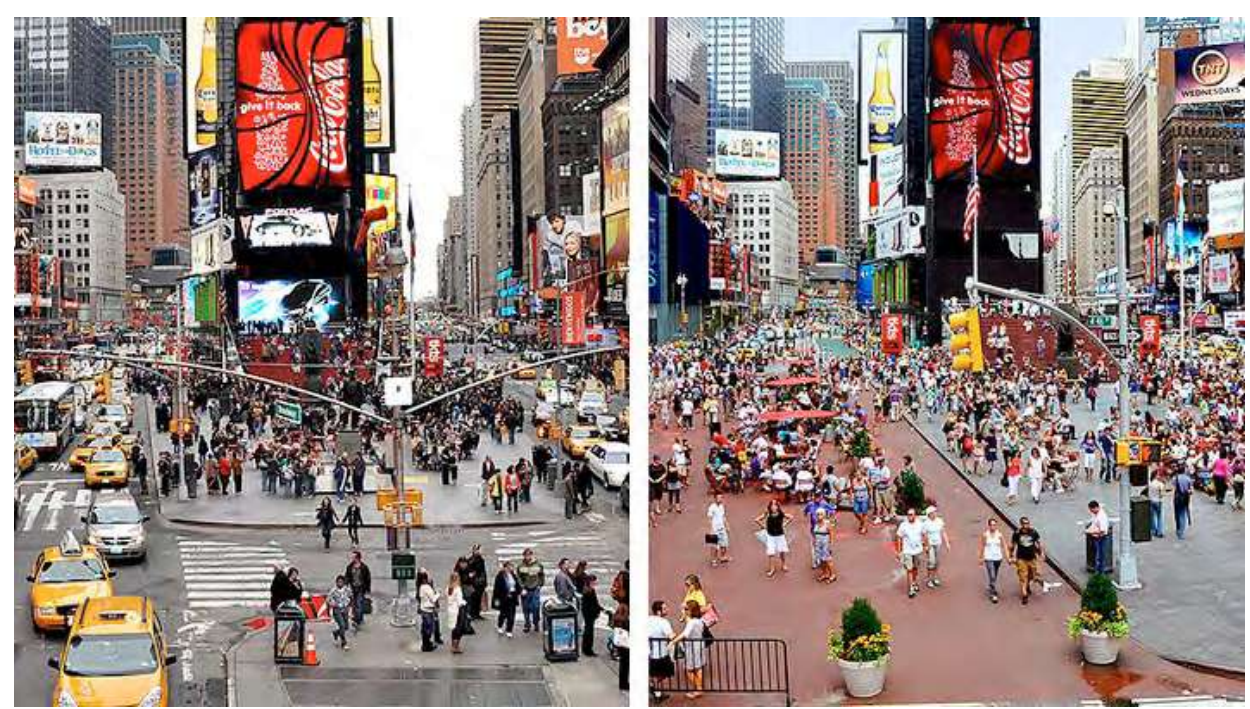

Foto 66 | Times Square antes e depois das intervenções

Fonte: NYC DOT/Flickr

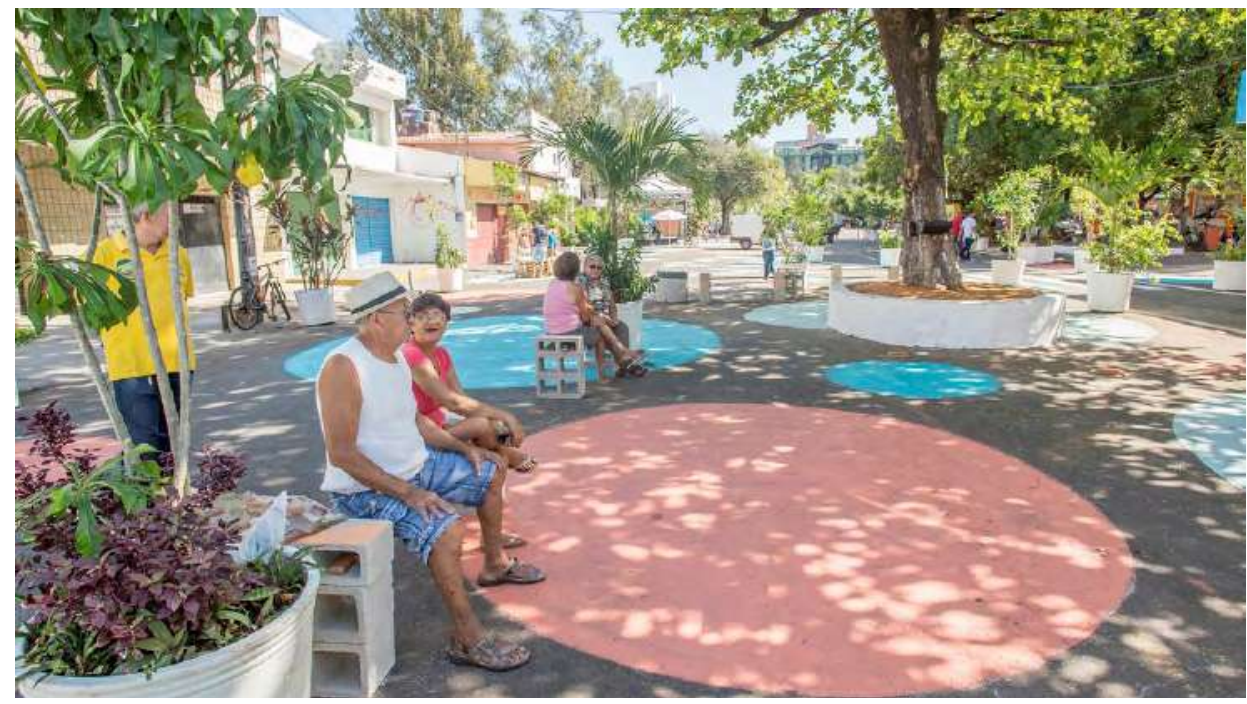

Foto 67 | Avenida Central da Cidade 2000, em Fortaleza

Fonte: Rodrigo Capote, WRI Brasil 


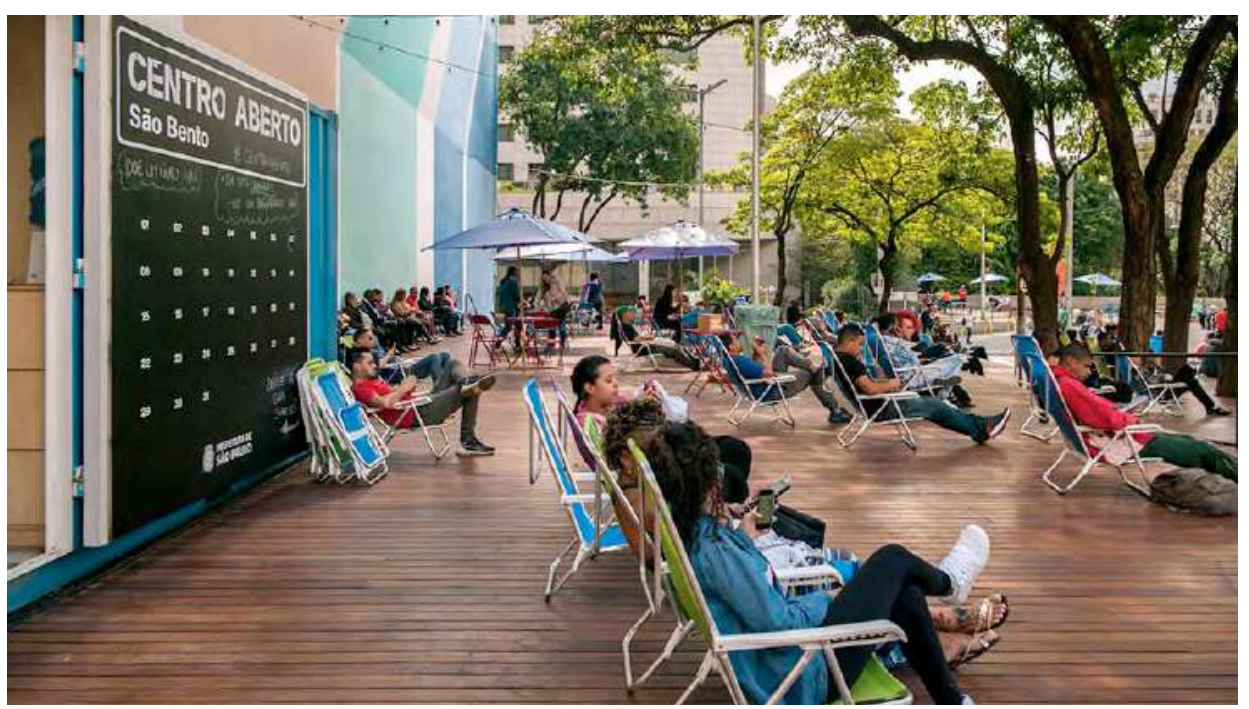

Foto 68 | Centro Aberto, São Paulo

Fonte: Prefeitura de São Paulo

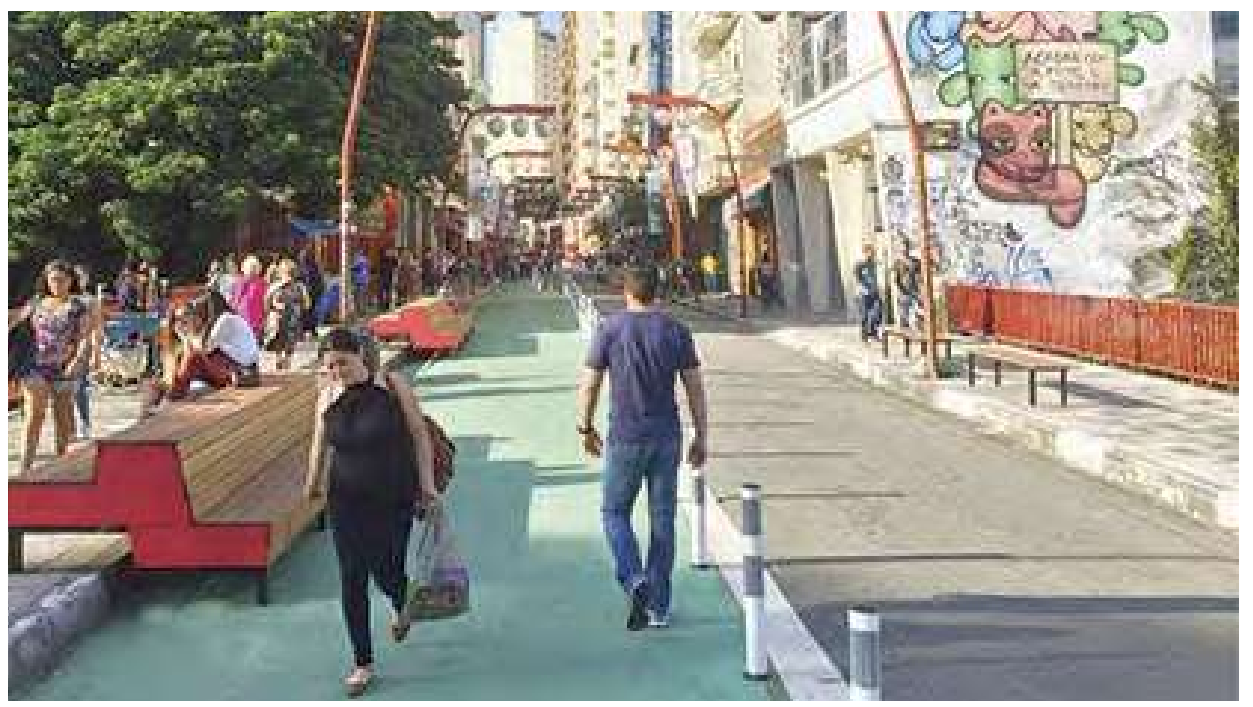

Foto 69 | Rua Galvão Bueno, em São Paulo, com a ampliação da calçada e criação de espaços de convivência

Fonte Prefeitura de São Paulo 
A faixa verde para pedestres na Avenida Liberdade foi implantada em 2015, como projeto piloto da CET para locais com fluxo alto de pedestres. Foi transformada em calçada em janeiro de 2019. O período de experimentaçăo foi longo, mas ajudou na comprovaçấo da necessidade de ampliaçăo do espaço do pedestre na regiăo.

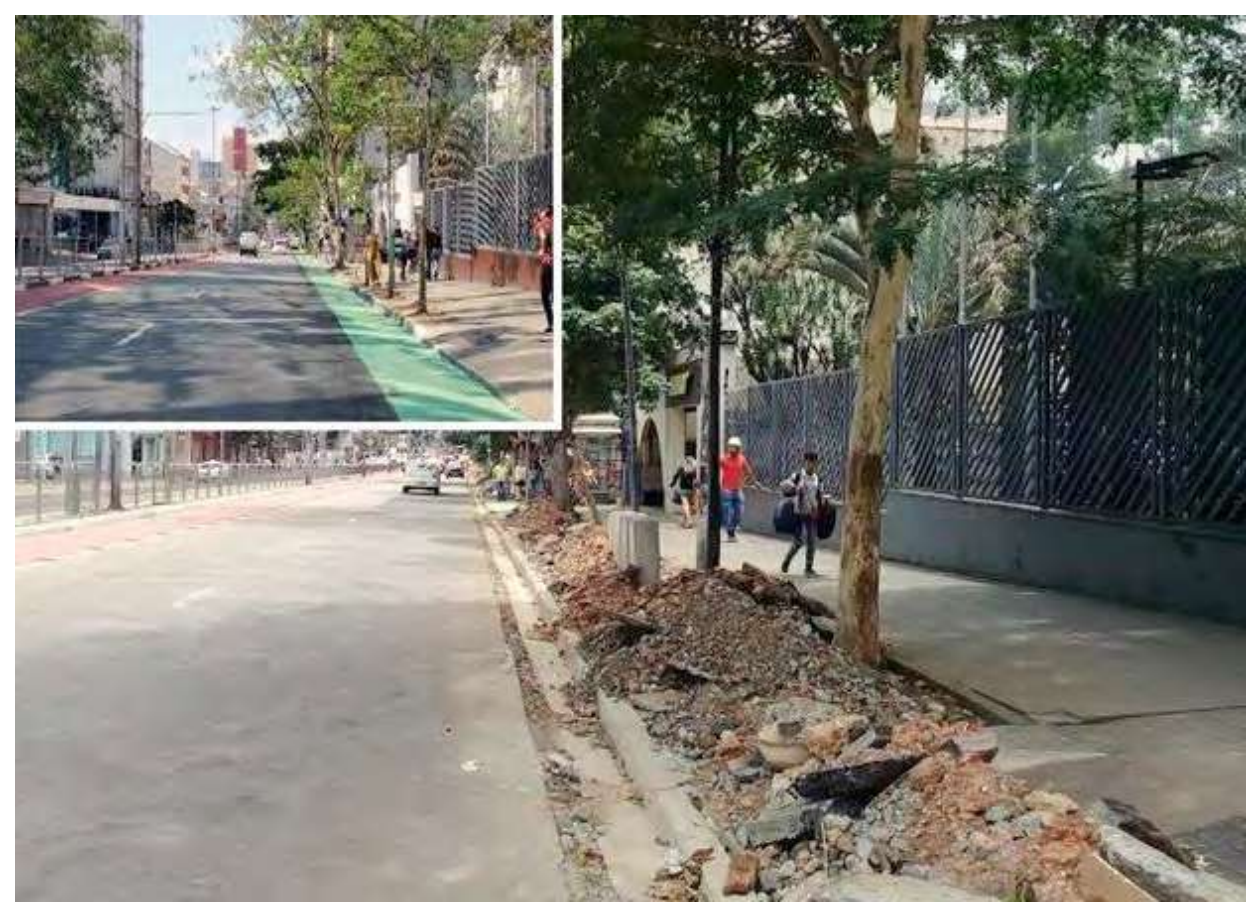

Foto 70 | Faixa verde para pedestres na Avenida Liberdade em 2015 e obra da calçada em 2019 Fonte: Mobilize Brasil

O ITDP (2018e) acredita que o sistema de bicicletas compartilhadas pode contribuir positivamente para o urbanismo tático e o desenvolvimento do lugar "placemaking": 
Strategically located bikeshare stations can contribute to placemaking, like here in the Tribeca neighborhood of New York City where an asphalt mural activates the pedestrian plaza outside of a subway station $^{7}$ (ITDP, 2018e, p. 38).

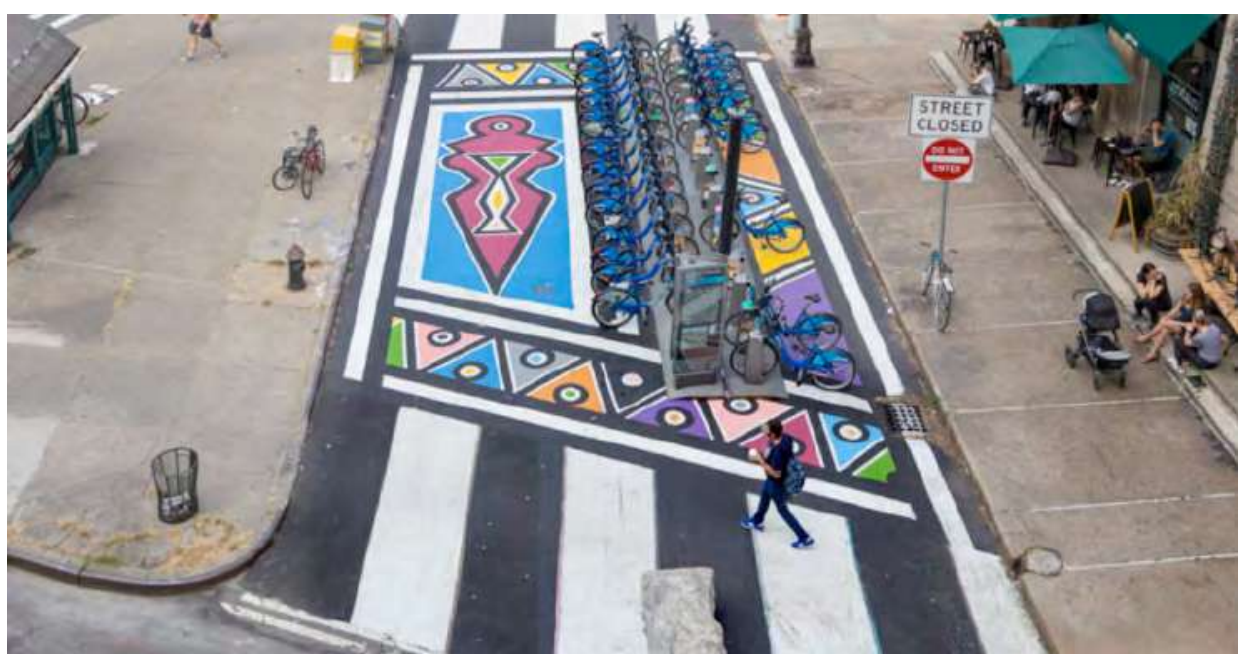

Foto 71 | Estação de bicicletas compartilhadas em Nova lorque Fonte: NYC Department of Transportation (ITDPe, 2018, p. 38).

(...) station location can be its own exercise in changing the street. We used bike-share stations to protect bike paths and to increase visibility on the street for pedestrians. Involving New Yorkers in the station selection process helped guide where we placed the racks in the first place and ensured that each location had a kind of local ownership ${ }^{8}$ (SADIK-KHAN, 2016, p. 203).

7 Estações de bicicletas compartilhadas estrategicamente localizadas podem contribuir para a criação de lugares, como aqui no bairro de Tribeca, em Nova lorque, onde um mural de asfalto ativa a praça de pedestres em frente a uma estação de metrô (tradução nossa).

8 A localização da estação pode ser o seu próprio exercício em mudar a rua. Usamos estações de compartilhamento de bicicletas para proteger ciclovias e aumentar a visibilidade na rua para 
Niel Brenner (2016) fala sobre a exposiçăo do Museu de Arte Moderna de Nova York de 2014, cujo tema era o crescimento desigual das cidades, que ensejou a reflexăo por diversos pensadores a respeito do urbanismo tático. Chegaram à conclusâo de que ele surge em meio à crise de governança nas cidades contemporâneas, em que tanto os mercados quanto o Estado falharam ao nâo providenciar bens públicos básicos às populaçôes urbanas em rápida expansăo.

Além disso, é mobilizado pelas pessoas e por organizaçôes culturais, e nâo por açôes municipais, para enfrentar as açôes urbanas emergentes. Por serem intervençôes rápidas e pontuais, podem ser consideradas impulsivas, efêmeras e espontâneas, o que torna a escala limitada também. “O urbanismo tático é, muitas das vezes, apresentado como um modelo de açăo de "fonte aberta" e como uma forma de 'reapropriaçâo' do espaço urbano por seus usuários" (BRENNER, 2016, p.9). O urbanismo tático tem potencial para corrigir problemas da cidade que as instituiçôes estatais e os procedimentos de planejamento urbano formais nâo conseguiram sanar.

Teddy Cruz $^{9}$ ressalta, no artigo, que talvez o papel mais importante do urbanismo tático seja o de base para o questionamento do urbanismo contemporâneo, e em suas intervençôes pode ser "coproduzida a cidade,

pedestres. Envolver os nova-iorquinos no processo de seleção de estações ajudou a orientar onde colocamos as docas e garantiu que cada estação tivesse um tipo de apropriação local (tradução nossa).

9 Teddy Cruz é pensador urbano e um dos curadores da exposição "Uneven Growth: Tactical Urbanism for Expanding Megacities" realizada no MoMa, em Nova lorque, em 22 de novembro de 2014. 
assim como novos modelos de convivência e coexistência para se avançar na agenda de inclusăo socioeconômica" (BRENNER, 2016, p.12).

Lydon e Garcia (2015) revelam que o urbanismo tático é a resposta ao sistema lento e convencional do processo de construçâo e intervençăo nas cidades, e que ele permite o redesenho e a reprogramaçăo do espaço público pelas pessoas.

In many ways, Tactical Urbanism is a learned response to the slow and siloed conventional city building process. For citizens, it allows the immediate reclamation, redesign, or reprogramming of public space $\mathrm{e}^{10}$ (LYDON; GARCIA, 2015, p.3).

10 De muitas maneiras, o Urbanismo Tático é uma resposta aprendida ao processo convencional lento e desconexo de construção da cidade. Para os cidadãos, permite a imediata recuperação, redesenho ou reprogramação do espaço público (tradução nossa). 


\subsection{Considerações finais}

_Importância da experimentação

Qualquer mudança na distribuiçáo do uso do espaço público traz de imediato a rejeiçăo, por modificar algum costume e aspecto da vida pessoal. A experimentaçăo como processo de urbanismo contemporâneo possibilita o contato com soluçóes diferentes, que na teoria podem parecer impossíveis, mas no cotidiano têm sua graça e coerência.

O conceito de coletividade é essencial no convívio urbano, e apesar do sentimento intrínseco egoísta do ser humano, o reconhecimento de soluçóes exitosas que passam a ser aceitas, quando experimentadas, e, por fim, aproveitadas e utilizadas é importante para a viabilizaçáo das açóes. O urbanismo tático tem apresentado cada vez mais experiências que começaram como temporárias e foram posteriormente efetivadas como intervençóes urbanas.

A autorizaçáo provisória de estaçóes, como no caso da crise do viaduto em Sáo Paulo, propiciou o início embrionário de um processo participativo com base na experimentaçăo da estaçâo instalada, porém, apenas as reclamaçóes foram recebidas e atendidas, ocasionando a retirada ou a relocaçăo de estaçóes. Năo houve canal para o recebimento de elogios e das necessidades dos usuários do sistema de compartilhamento de bicicletas.

O processo participativo poderia ser realizado após meses de testes reais do funcionamento das estaçóes, com o objetivo de aproximar as pessoas do 
projeto e entender as reclamaçóes e a demanda real de cada localizaçăo.

Dessa forma, haveria espaço para a opiniăo dos usuários de bicicleta compartilhada, e assim, a ponderaçăo dos argumentos tanto dos que desejam a retirada das estaçôes, quanto daqueles prejudicados pela remoçấo, para a tomada de decisấo a respeito da manutençâo da estaçăo no local.

Caso houvesse audiências públicas antes da implantaçâo das estaçôes, acredito que o sistema seria prejudicado, porque a nâo experimentaçấo da ocupaçâo do espaço de maneira incomum, com bicicletas no lugar de automóveis, poderia causar maior rejeiçăo que aceitaçăo. Muitas pessoas começam a usar a bicicleta na cidade após a experimentaçăo da bicicleta compartilhada. Antes de as ter à disposiçăo, essas pessoas poderiam também ser contrárias à implantaçăo das estaçôes.

Ao longo da dissertaçăo discorri sobre a seguinte reflexấo: como disputar o espaço da rua?

Ocupando-o. Ocupando todos os espaços possíveis e aparentemente impossíveis, posicionando-se e consolidando sua importância entre os modais existentes. Quanto mais ciclistas nas ruas, ciclovias e ciclofaixas, mais eles serăo considerados na agenda política da mobilidade, e mais serăo vistos pelos demais modos de transporte. Ao circular, e cada vez em maior quantidade, os ciclistas solicitam mais espaço, e começam a conquistar pequenos lugares antes utilizados somente pelos automóveis. Nesse sentido, considero importantíssimo o papel dos sistemas de bicicletas compartilhadas, por 
induzirem o uso da bicicleta e convidarem as pessoas a pedalar no cotidiano de seus percursos.

No entanto, o poder público desempenha papel igualmente essencial, porque contribui com a infraestrutura cicloviária, principalmente próximo a estaçôes de transporte público (estaçôes de metrô, trem e corredores de ônibus). A combinaçăo de ciclovias e ciclofaixas, integraçăo modal e sistema de bicicleta compartilhada garante maior número de ciclistas. E apresenta potencial de auxílio no acesso ao transporte público com o aumento do PNT, no DOTS, com a valorizaçăo e o incentivo das mobilidades ativas, e colabora com a inclusấo social.

O termo mobilidade às vezes é confundido com transporte, o que prejudica seu entendimento. Segundo WRI Brasil (2018a):

Mobilidade significa a capacidade de chegar aos lugares necessários para a vida urbana, como trabalho, escola, parques, comércio, hospitais etc, ou seja, viabilizar as viagens essenciais para o exercício dos direitos básicos dos cidadāos. Mobilidade năo é ter uma maneira de se deslocar, mas um sistema de possíveis modos de transporte. E que tenha qualidade.

Essa caracterizaçâo da mobilidade relacionada a sistemas de possíveis modos de transporte atua favoravelmente à mudança de paradigma necessária devido à crise da mobilidade urbana nas cidades brasileiras, e altera o pensamento tradicional de tratar o trânsito de maneira isolada. Segundo o Ministério das Cidades (2007b), "deve-se adotar uma visăo sistêmica sobre toda a movimentaçăo de bens e de pessoas, envolvendo todos os modos e todos os elementos que produzem as necessidades destes deslocamentos". 
Acredito que a bicicleta e demais modos ativos de deslocamento devem ser considerados como parte dessa visăo sistêmica e, portanto, da mobilidade urbana. A evoluçấo do leque de mobilidades ativas é visível e a participaçăo das bicicletas compartilhadas nesse processo me parece irrefutável.

Entretanto, é inevitável a cobrança para que a soluçâo seja replicada em outras regióes da cidade, de forma a reconhecer o potencial de uso cotidiano e do papel que a bicicleta pode ter como transporte público, integrá-la com outros modais, para que essa alternativa constitua o primeiro ou o último trecho da viagem, de maneira saudável, eficiente e divertida.

Na próxima vez em que usarem o termo mobilidade como sinônimo de transporte, pergunte se as noçóes de qualidade, acessibilidade, segurança e confiabilidade estăo inseridas no contexto. Se a resposta for negativa, saiba que náo se trata de mobilidade. (WRI BRASIL, 2018a). 



\section{Referências}

ANDRADE, Victor; RODRIGUES, Juciano Martins (Coord.). Economia da Bicicleta no Brasil. Laboratório de Mobilidade Sustentável da Universidade Federal do Rio de Janeiro (UFRJ/LABMOB) e Associaçăo Brasileira do Setor de Bicicletas (Aliança Bike). Rio de Janeiro, 2018. Disponível em: <http://economiadabicicleta.org.br/>. Acesso em: 20 jan. 2019.

BAZANI, Adamo. Opiniăo: Balanço de Haddad na mobilidade urbana. Diário do Transporte, Săo Paulo, 29 de dez. de 2016. Disponível em: <https://diariodotransporte.com.br/2016/12/29/opiniao-balanco-de-haddad-na-mobilidade-urbana/〉. Acesso em: 24 dez. 2018.

BEIJING bans new bikes as sharing schemes cause chăos. BBC News, Londres, 8 set. 2017. Disponível em: < https://www.bbc.com/news/business-41197341>. Acesso em: 19 jan. 2019.

BLOOMBERG NEWS. Bike-Share Pioneer Ofo Flirted With Bankruptcy as Cash Dried Up. Bloomberg, Nova York, 20 dez. 2018. Disponível em: <https://www.bloomberg. com/news/articles/2018-12-20/bike-share-pioneer-ofo-flirted-with-bankruptcy-as-cash-dried-up>. Acesso em: 19 jan. 2019.

BRENNER, Neil. Seria o "urbanismo tático" uma alternativa ao urbanismo neoliberal? E-metropolis, Nova York, n²7, ano 7, 2016. Traduçâo: Pedro Paulo Machado Bastos. Disponível em: <http://emetropolis.net/system/artigos/arquivo_pdfs/000/000/201/ original/emetropolis27_capa.pdf?1485998522>. Acesso em: 31 jan. 2019.

CALLIL, Victor; COSTANZO, Daniela. Contagem de ciclistas na Rua da Consolaçáo. CEBRAP, Săo Paulo, maio 2017. Disponível em: ‘https://cebrap.org.br/wp-content/ uploads/2017/05/Contagem-de-Ciclistas-da-Rua-da-Consolac\%CC\%A7a\%CC\%83oMaio-2017.pdf $>$. Acesso em: 8 jan. 2019.

CALLIL, Victor; COSTANZO, Daniela. Inserçăo e padróes de viagens de sistemas de bike-sharing em três cidades: Sáo Paulo, Cidade do México e Nova York. Revista Transporte y Territorio. Săo Paulo, v. 19, p. 7-16. 2018. Disponível em: <https:// dialnet.unirioja.es/servlet/articulo?codigo=6661181 . Acesso em: 8 jan. 2019. 
CÂMARA MUNICIPAL DE SÂO PAULO. Projeto de Lei establece critérios para implantaçâo de ciclovías em Sâo Paulo. Câmara Municipal de Sáo Paulo, Săo Paulo, 4 ago. 2018. Disponível em: < http://www.saopaulo.sp.leg.br/blog/projeto-de-lei-estabelece-criterios-para-implantacao-de-ciclovias-em-sao-paulo/>. Acesso em: 8 jan. 2019.

CDMX. Hacia uma ciudad ciclista. Dirección de Cultura, Diseño e Infraestructura Ciclista. SEDEMA, Cidade do México, 2017. Disponível em: «https://www.sedema. cdmx.gob.mx/comunicacion/nota/presenta-la-sedema-el-libro-cdmx-hacia -una-ciudad-ciclista-en-el-marco-del-foro-mundial-de-la-bicicleta>. Acesso em: 10 dez. 2018.

CDMX. Encuesta Ecobici 2014. Disponível em: <https://www.ecobici.cdmx.gob.mx/ sites/default/files/pdf/ecobici_2014_encuesta.pdf>. Acesso em: 26 jan. 2019.

CET (Companhia de Engenharia de Tráfego). Mapa de infraestrutura cicloviária. Disponível em: 〈http://www.cetsp.com.br/consultas/bicicleta/mapa-de-infraestrutura-cicloviaria.aspx>. Acesso em: 19 fev. 2019.

CET (Companhia de Engenharia de Tráfego). Critérios de sinalizaçăo diversos.

Estaçăo de bicicletas compartilhadas. Disponível em: <http://www.cetsp.com.br/ media/735081/18G-Estacao-de-bicicletas-compartilhadas-Revisao-A.pdf $>$. Acesso em: 17 fev. 2019.

CICLOCIDADE. Contagem de ciclistas: cruzamento da Av. Faria Lima com Av. Rebouças. Săo Paulo, 2015a. Disponível em: <https://www.ciclocidade.org.br/ noticias/681-contagem-de-ciclistas-faria-lima-2015>. Acesso em: 19 fev. 2019.

Contagem de ciclistas: cruzamento da Av. Faria Lima com Av. Rebouças. Sáo Paulo, 2018a.

Nota sobre a inauguraçáo do novo sistema de bicicletas compartilhadas Bike Sampa. Ciclocidade (2018b), Sáo Paulo, 30 jan. 2018. Disponível em: <https://www. ciclocidade.org.br/noticias/994-nota-sobre-a-inauguracao-do-novo-sistema-debicicletas-compartilhadas-bike-sampa>. Acesso em: 9 jan. 2019. 
Pesquisa Perfil de quem usa a bicicleta na cidade de Sáo Paulo. Idealizaçăo e Coordenaçấo: Transporte ativo. Desenvolvimento: Observatório das Metrópoles. Coordenaçâo em Săo Paulo: Ciclocidade - Associaçâo dos Ciclistas Urbanos de Sâo Paulo. São Paulo, 2015b. Disponível em: <https://www.ciclocidade.org.br/ noticias/809-pesquisa-perfil-de-quem-usa-bicicleta-na-cidade-de-sao-paulo-relatorio-completo>. Acesso em 2 jan. 2019.

COMISSĂO EUROPEIA. Cidades para bicicletas, cidades de futuro. Luxemburgo: Serviço das Publicaçóes Oficiais das Comunidades Europeias, 2000. Disponível em: 〈http://ec.europa.eu/environment/archives/cycling/cycling_pt.pdf〉. Acesso em: 19 jan. 2019.

COSTA, Célia. Estaçóes do Bike Rio que ocupam vagas de estacionamento causam polêmica na Zona Sul. 0 Globo, Rio de Janeiro, 28 jan. 2015. Disponível em: <https:// oglobo.globo.com/rio/estacoes-do-bike-rio-que-ocupam-vagas-de-estacionamentocausam-polemica-na-zona-sul-15170179>. Acesso em: 8 dez. 2018.

CRUZ, William. Lei obriga implantar ciclovias ao criar ou reformar avenidas, pontes e túneis em Săo Paulo. Vá de Bike, Sáo Paulo, 15 dez. 2015. Disponível em: <http:// vadebike.org/2013/01/construcao-reforma-avenidas-sao-paulo-ciclovia/>. Acesso em 25 jan. 2019.

Reinaugurado o empréstimo e aluguel de bicicletas no Rio, o BikeRio. Vá de Bike, Sâo Paulo, 28 out. 2011. Disponível em: <http://vadebike.org/2011/10/ reinaugurado-o-emprestimo-e-aluguel-de-bicicletas-no-rio-o-bikerio/. Acesso em: 8 dez. 2018.

CYMBALISTA, Renato (org.). Situando Jane Jacobs. São Paulo: Annablume, 2018.

DEMAIO, Paul. Bike-sharing: History, Impacts, Models of Provision, and Future. Journal of Public Transportation, Vol. 12, No. 4, 2009. Disponível em: <https://www. nctr.usf.edu/jpt/pdf/JPT12-4DeMaio.pdf`. Acesso em: 19 jan. 2019.

DENATRAN - Departamento Nacional de Trânsito. Dados estatísticos de frota. Brasília, DF, 2018. Disponível em: <http://www.denatran.gov.br/estatistica/237-frota-veiculos>. Acesso em: 16 jan. 2019. 
DIAS, Eduardo. Vila Velha recolhe bicicletas compartilhadas de empresa năo autorizada. Gazeta online, Vitória, 8 fev. 2019. Disponível em: <https://www.gazetaonline. com.br/noticias/cidades/2019/02/vila-velha-recolhe-bicicletas-compartilhadasde-empresa-nao-autorizada-1014167288.html. Acesso em: 9 fev. 2019.

DICKEY, Megan Rose. Scoot unveils new lock to prevent scooter theft. Techcrunch, Sâo Francisco, dez. 2018. Disponível em: <https://techcrunch.com/2018/12/12/ scoot-unveils-new-lock-to-prevent-scooter-theft/>. Acesso em 25 jan. 2019.

DIÓGENES, Juliana; MENGUE, Priscila. Em 1 ano, uso do principal serviço de compartilhamento de bike cai 41,8\%. Estadăo, Săo Paulo, 8 set. 2017. Disponível em: <https:// sao-paulo.estadao.com.br/noticias/geral,em-1-ano-uso-do-principal-servico-decompartilhamento-de-bike-cai-41-8,70001976154>. Acesso em: 6 dez. 2018.

\section{DISTRICT DEPARTMENT OF TRANSPORTATION (DDOT). Dockless Vehicle}

Sharing Demonstration. Washington, 2018. Disponível em: <https://ddot.dc.gov/ sites/default/files/dc/sites/ddot/publication/attachments/Dockless\%20 Demonstration\%20Evaluation\%20010319.pdf>. Acesso em: 25 jan. 2019.

\section{DOTS Cidades. Manual de Desenvolvimento Urbano Orientado ao Transporte}

Sustentável. Embarq Brasil. 2a ediçăo, 2015. Disponível em: <http://wricidades.org/ research/publication/dots-cidades-manual-de-desenvolvimento -urbano-orientado-ao-transporte>. Acesso em 1 dez. 2018.

DURAN, Sabrina. Compartilhamento de bicicletas: prefeitura à mercê do setor privado?. AG Jornalismo, Sáo Paulo, 2 fev. 2016. Disponível em: < http://ag.jor.br/ blog/2016/02/02/contrato-bikesharing-itau-bradesco/>. Acesso em: 9 jan. 2019.

ESTEVES, Gheisa R. T; BARBOSA, Sônia R. C. S.; SILVA, Ennio P.; ARAUJO, Paula D. Estimativa dos efeitos da Poluiçáo Atmosférica sobre a Saúde Humana: algumas possibilidades metodológicas e teóricas para a cidade de Săo Paulo. In: ANPPAS, II, 2004, Indaiatuba. Disponível em: ‘http://www.anppas.org.br/encontro_anual/ encontro2/GT/GT12/gheisa_roberta.pdf> Acesso em: 18 nov. 2018. 
FABIANO, Maria Lucia Alves; SOCIAIS-PUC, Doutoranda-Ciências. A Mobilidade urbana e o papel da bicicleta como indutor de inclusáo social e de transformaçáo da cidade. In: COLÓQUIO BRASIL - PORTUGAL, 4., 2016, São Paulo. Estratégias de Projeto e Intervençấo nas Metrópolis Contemporâneas e Perspectivas, Săo Paulo: Universidade Presbiteriana Mackenzie, 2016, p.1-13. Disponível em: <http://portal. mackenzie.br/fileadmin/ARQUIVOS/PUBLIC/SITES/PORTAL/IV_COLOQUIO_ BRASIL-PORTUGAL/25.pdf $>$. Acesso em: 8 jul. 2017.

FERNÁNDEZ, A. C. The contribution of bike-sharing to sustainable mobility in Europe. 2011. 235 f. Tese (Doutorado) - Technischen Universität Wien, Viena, 2011.

FORTUNATI, Jenna. Recycling the abandoned dockless bikes in China is harder than you think. Virginia, Mobility Lab, 13 abr. 2018. Disponível em: <https://mobilitylab. org/2018/04/13/recycling-the-abandoned-dockless-bikes-in-china-is-harder-than -you-think/>. Acesso em: 19 jan. 2019.

FRADE, Inês; RIBEIRO, Anabela. Bicycle sharing systems demand. EWGT 2013 - 16th Meeting of the EURO Working Group on Transportation. Universidade de Coimbra, Departamento de Engenharia Civil. Coimbra, Portugal, 2013. Disponível em: 〈https://www.sciencedirect.com/science/article/pii/S187704281400086X〉. Acesso em: 19 jan. 2019.

FRANCO, Maria de Assunçăo Ribeiro. Infraestrutura Verde em Săo Paulo: o caso do Corredor Verde Ibirapuera-Villa Lobos. Sáo Paulo. Revista Labverde $n^{\circ} 01,2010$, p.141. Disponível em: <http://www.revistas.usp.br/revistalabverde/article/view/ 61284/64219>. Acesso em: 24 dez. 2018.

FRÚGOLI JR, Heitor. Pesquisas etnográficas e vivências: um olhar sobre a cidade de Sáo Paulo. Ponto Urbe [Online], 2016. Disponível em: <http://pontourbe.revues. org/3087>. Acesso em: 5 jul. 2017.

GANCIA, Barbara. Para Maluf, engarrafamento é bençăo divina. Folha de S.Paulo, Sáo Paulo, 1 mar. 1996. Disponível em: <https://www1.folha.uol.com.br/ fsp/1996/3/01/cotidiano/6.html>. Acesso em: 16 jan. 2019.

GEHL, Jan. Cidades para pessoas. Traduçáo Anita Di Marco. 2. Ed. Săo Paulo: Perspectiva, 2013. 
GORDON, Doug. The Bike Share Criticism Challenge. Brookling Spoke, Nova York, 9 maio 2013. Diponível em: < https://brooklynspoke.com/2013/05/09/the-bike-sharecriticism-challenge/>. Acesso em: 27 jan. 2019.

GUARNACCIA, Matteo. Provos: Amsterdam e o nascimento da contracultura. 2. Ed. Sâo Paulo: Conrad Editora do Brasil, 2010.

GUIMARÁES, Saulo. Falta de bicicletas transforma Bike Rio em dor de cabeça.

Veja Rio, Rio de Janeiro, 26 ago. 2017. Disponível em: <https://vejario.abril.com.br/ cidades/falta-de-bicicletas-transforma-bike-rio-em-dor-de-cabeca/>. Acesso em: 8 dez. 2018.

HARKOT, Marina. Bicicletas Yellow sâo livres para circular - na área que interessa à empresa. Labcidade, Sáo Paulo, 30 nov. 2018. Disponível em: <http://www.labcidade. fau.usp.br/bicicletas-yellow-sao-livres-para-circular-na-area-que-interessa-a-empresa/>. Acesso em: 26 jan. 2019.

HALL, Peter. Cidades do Amanhă: uma história intelectual do planejamento e do projeto urbanos no século XX. Traduçâo Maria Alice Junqueira Bastos, Pérol de Carvalho, Anita Guimarăes. 4a ediçăo, Săo Paulo: Perspectiva, 2016.

HOLLOWAY, John. Fissurar o capitalismo. Traduzido por Daniel Cunha. Săo Paulo: Publisher Brasil, 2013.

ITDP BRASIL. Guia de Compartilhamento de Bicicletas Compartilhadas. Rio de Janeiro, 2014. Disponível em: <https://www.itdp.org/wp-content/uploads/2013/12/ ITDP-Brasil_Guia-de-Planejamento-de-Sistemas-de-Bicicletas-Compartilhadas.pdf $>$. Acesso em: 10 jan. 2019.

(2018). Intervençăo urbana temporária: (Re)pensando a rua em Santana. Relatório de atidade, março de 2018. Disponível em: <http://itdpbrasil.org.br/ wp-content/uploads/2018/04/ITDP_TA_RELATORIO_BIENAL_SANTANA.pdf>. Acesso em: 30 jan. 2019. 
(2017a). Mobilidade e equidade: a proximidade do transporte entre diferentes faixas de renda nas regiôes metropolitanas brasileiras. Archdaily, Rio de Janeiro, 6 jun. 2017. Disponível em: <https://www.archdaily.com.br/br/873024/ mobilidade-como-equidade-a-proximidade-do-transporte-entre-diferentes-faixasde-renda-nas-regioes-metropolitanas-brasileiras>. Acesso em: 3 jan. 2019.

(2017b). Padráo de Qualidade DOTS. 3a ed. Nova York: ITDP, 2017. Disponível em: <http://itdpbrasil.org.br/wp-content/uploads/2017/12/DU-Padrao-deQualidade-DOTS-2017.pdf>. Acesso em 16 jan. 2019.

(2017c). Políticas de estacionamento em edificaçōes na cidade do Rio de Janeiro: análise dos efeitos da legislaçáo no desenvolvimento urbano. Rio de Janeiro, 2017. Disponível em: <http://itdpbrasil.org.br/wp-content/uploads/2017/07/relatorio-politicas-de-estacionamento-itdp-julho-2017.pdf>. Acesso em: 15 dez. 2018.

\section{ITDP BRASIL (2015). Política de Mobilidade por Bicicletas e Refe Cicloviária da}

Cidade de Săo Paulo: Análise e Recomendaçóes. Rio de Janeiro, 2015. Disponível em: 〈http://itdpbrasil.org.br/wp-content/uploads/2016/03/Relatorio-CIclovias-SP.pdf>. Acesso em: 10 jan. 2019.

(2016). Sistema de Bicicletas Compartilhadas em Belo Horizontel, Distrito Federal, Rio de Janeiro e Sáo Paulo. Rio de Janeiro, 2016. Disponível em: <http:// itdpbrasil.org.br/wp-content/uploads/2016/06/2016-ITDP-relatorio-bike-share. pdf>. Acesso em: 9 jan. 2019.

ITDP CHINA (2017). The Development and Policy Recommendations for Dockless Bike Share (DBS) in China. Liu Shaokun, Li Wei, Deng Han. Disponível em: http:// www.itdp-china.org/media/dbs/article/Dockless\%20Bike\%20Share\%20(DBS)\%20 in\%20China.pdf. Acesso em: 10 jan. 2019.

ITDP US (2018a). Dockless Bikeshare: What we know so far. ITDP, Nova York, 4 jan. 2018. Disponível em: <https://www.itdp.org/2018/01/04/dockless-bikeshare -know-so-far/>. Acesso em: 9 jan. 2019.

(2018b). E-scooters could be a last-mile solution for everyone. ITDP, Nova York, 14 dez. 2018. Disponível em: <https://www.itdp.org/2018/12/14/e-scooters -last-mile-solution/>. Acesso em: 11 jan. 2019. 
(2018c). Optimizing Dockless Bikeshare for cities. ITDP, Nova York, 15 maio 2018. Disponível em: <https://www.itdp.org/publication/optimizing-dockless-bikeshare-cities/>. Acesso em 9 jan. 2019.

(2018d). Scooters are not a public safety crisis, but cars still are. ITDP, Nova York, 20 nov. 2018. Disponível em: https://www.itdp.org/2018/11/20/scootersnot-public-safety-crisis/. Acesso em: 11 jan. 2019.

(2018e). The Bike Sharing Planning Guide. Nova York, 2018. Disponível em: <https://3gozaa3xxbpb499ejp30lxc8-wpengine.netdna-ssl.com/wp-content/ uploads/2013/12/BSPG_digital.pdf >. Acesso em: 5 jan. 2019.

ITDP; WRI BRASIL. Onde estăo as pessoas e o transporte na cidade de Sáo Paulo? ITDP;WRI Brasil, 2017. Disponível em: 〈https://d.pr/spWB>. Acesso em: 16 jan. 2019.

JACOBS, Jane. Morte e vida de grandes cidades. 3ed. Săo Paulo: WMF Martins Fontes, 2011.

KOOPS, Enne. Provo pleitte in 1965 voor elektrische fiets. Historiek, 2016. Disponível em: <https://historiek.net/provo-pleitte-in-1965-voor-elektrischefiets/58943/>. Acesso em: 3 jul. 2018.

LAZZERI, Thais. Uso de ciclovia da Faria Lima dispara, e "rush" é para ir ao trabalho. Folha de S.Paulo, Sâo Paulo, 4 ago. 2018. Disponível em: <https://www1.folha.uol. com.br/cotidiano/2018/08/uso-de-ciclovia-da-faria-lima-dispara-e-rush-e-para -ir-ao-trabalho.shtml>. Acesso em: 8 dez. 2018.

LEE, Emma. Bike-rental firm Mobike to spin off European arm. Technode, Shangai, 12 dez. 2018. Disponível em: <https://technode.com/2018/12/12/mobike-spin-off -european-arm/>. Acesso em: 25 jan. 2019.

LEMOS, Letícia. Bicicletas compartilhadas, mas năo públicas. Labcidade, Săo Paulo, 6 fev. 2018. Disponível em: <http://www.labcidade.fau.usp.br/bicicletas-compartilhadas-mas-nao-publicas-2/>. Acesso em: 15 jan. 2019.

LOBO, Renato. Gestăo Haddad completa meta de $400 \mathrm{~km}$ de ciclovias. Viatrolebus, Săo Paulo, 8 dez. 2016. Disponível em: https://viatrolebus.com.br/2016/12/gestaohaddad-completa-meta-de-400-km-de-ciclovias/. Acesso em 8 jan. 2019. 
LIMA, Andressa. Ciclistas reclamam do Bike Sampa; falta de bicicletas é apenas um dos problemas. Metro Jornal, Săo Paulo, 19 jun. 2017. Disponível em: <https://www. metrojornal.com.br/foco/2017/06/19/usuarios-reclamam-bike-sampa-falta-debicicletas-e-apenas-um-dos-problemas.html>. Acesso em: 06 dez. 2018.

LINKE, Clarisse. O preço justo do gelo e os carros da Zona Sul. Projeto Colabora, Rio de Janeiro, 2018. Disponível em: https://projetocolabora.com.br/mobilidade/ estacionamentos-x-bicicletarios-no-rio/. Acesso em 29 de nov. de 2018.

LYDON, Mike; GARCIA, Anthony. Tactical Urbanism: short-term action for longterm change. Washington: Island Press, 2015.

MACEDO, Silvio Soares. Paisagismo Brasileiro na Virada do Século 1990-2010. Săo Paulo: Editora da Universidade de Săo Paulo; Campinas: Editora da Unicamp, 2012.

MALATESTA, Maria Emelina B. A História dos estudos de bicicleta na CET. Săo Paulo: Companhia de Engenharia de Tráfego. 2012, p. 58 - Boletim Técnico da CET, 50.

MALATESTA, Maria Ermelina Brosch. A bicicleta nas viagens cotidianas do Município de Săo Paulo. Tese de Doutorado. Sáo Paulo: FAUUSP, 2014.

MARQUES, Rafaela. ITDP lança o indicador PNT (People Near Transit). ITDP, Rio de Janeiro, 24 ago. 2015. Disponível em: 〈http://itdpbrasil.org/pnt/>. Acesso em: 22 set. 2018.

MARQUES, Rafaela. Colhendo frutos: Prefeitura de Sáo Paulo implementa açóes de segurança viária em Santana. ITDP, Rio de Janeiro, 16 jul. 2018. Disponível em: 〈http://itdpbrasil.org/santana2/>. Acesso em: 31 jan. 2019.

MARKS, Michael. People Near Transit: Improving accessibility and rapid transit coverage in large cities. ITDP, 2016. Disponível em: <https://www.itdp.org/ wp-content/uploads/2016/10/People-Near-Transit.pdf〉. Acesso em: 3 jan. 2019.

MIDGLEY, Peter. Bicycle-Sharing Schemes: Enhancing Sustainable Mobility In Urban Areas. Nineteenth Session. New York: United Nations. Department of Economic and Social Affairs, 2011. Disponível em: https://sustainabledevelopment. un.org/content/dsd/resources/res_pdfs/csd-19/Background-Paper8-P.MidgleyBicycle.pdf $>$. Acesso em: 11 out. 2018. 


\section{MINISTÉRIO DAS CIDADES (2007a). Coleçăo Bicicleta Brasil: Programa Brasileiro de}

Mobilidade por Bicicleta. Brasília, Secretaria Nacional de Transporte e da Mobilidade Urbana, 2007. Disponível em: <http://www.intt.gob.ve/repositorio/biblioteca/ texto_relacionados/Livro_20Bicicleta_20Brasil.pdf>. Acesso em 14 de mar. de 2018.

(2004). Política Nacional de Mobilidade Urbana Sustentável. Cadernos

MCidades - Mobilidade Urbana, 2004. Disponível em: <http://www.ta.org.br/site/ banco/7manuais/6politicanacionalmobilidadeurbanasustentavel.pdf`. Acesso em: 21 de mar. de 2018.

(2013). Planejamento em mobilidade urbana. Brasília, Secretaria Nacional de Transporte e da Mobilidade Urbana, 2013. Disponível em: <http://sectordialogues. org/sites/default/files/mobilidade_urbana_web.pdf>. Acesso em: 16 jan. 2019.

(2007b). PlanMob - Construindo a Cidade Sustentável. Caderno de Referência para elaboraçáo de Plano de Mobilidade Urbana. Brasília, Secretaria Nacional de Transporte e da Mobilidade Urbana, 2007. Disponível em: 〈http://www.cidades.gov. br/images/stories/ArquivosSEMOB/Biblioteca/LivroPlanoMobilidade.pdf $>$. Acesso em 01 fev. 2019.

MOBILIZE BRASIL. Em SP, prefeito aprova lei para restringir ciclovias e ciclofaixas. Mobilize Brasil, Săo Paulo, 9 nov. 2018.Disponível em: <http://www.mobilize.org.br/ noticias/10676/em-sp-prefeito-aprova-lei-para-restringir-ciclovias-e-ciclofaixas. html>. Acesso em: 9 jan. 2019.

NACTO. Bike Share in the US:2017. Disponível em:<https://nacto.org/ bike-share-statistics-2017/> e <https://nacto.org/wp-content/uploads/2018/05/ NACTO-Bike-Share-2017.pdf $>$. Acesso em: 5 de jan. de 2018.

NACTO. Guia Global de Desenho de Ruas. Global Designing Cities Initiative. Senac, 2018.

NAZELLE, Audrey. What would happen if we remove cars from cities? World

Economic Forum, Londres, 9 ago. 2018. Disponível em: <https://www.weforum.org/ agenda/2018/08/air-pollution-opportunity-not-just-problem?fbclid=IwAR1MpKSIPwQnydC5uP-vBCr6WpXYPhv_9PJzqJ230VZ52FtekFjHcvXH_rg>. Acesso em 27 out. 2018. 
PACHECO, Priscila. Mobilidade urbana: a bicicleta como ferramenta de integraçáo. TheCityFix Brasil, Porto Alegre, 30 ago. 2017. Disponível em: <http:// thecityfixbrasil.com/2017/08/30/mobilidade-urbana-a-bicicleta-como-ferramentade-integracao/>. Acesso em: 1 set. 2018.

PACHECO, Priscila. Urbanismo tático: um novo sentido, um novo lugar. TheCityFix Brasil, Porto Alegre, 7 maio 2014. Disponível em: <http://thecityfixbrasil. com/2014/05/07/urbanismo-tatico/>. Acesso em: 30 jan. 2019.

PASSEIO Ciclístico da Primavera reúne 15 mil nas ruas de São Paulo. Folha de S. Paulo, Sáo Paulo, 18 set. 1995. Disponível em: <https://www1.folha.uol.com.br/ fsp/1995/9/18/cotidiano/17.html. Acesso em: 1 dez. 2018.

PAULA FILHO, Alexandre Moura Alvez; SOUZA, Mayara Nunes Medeiros. A Promoçăo da Bicicleta no Ambiente Urbano como Instrumento de Concretizaçáo do Direito à Cidade Acessível, Democrática e Sustentável. In: PIRES, Antonio Cecílio Moreira; PIRES, Lilian Regina Gabriel Moreira (Orgs.). Mobilidade Urbana: desafios e sustentabilidade. Săo Paulo: Ponto e Linha, 2016. p.197-198.

PORCIDONIO, Gilberto. Novas estaçôes do Bike Rio geram polêmica entre moradores do Rio. 0 Globo, Rio de Janeiro, 28 maio 2018. Disponível em: <https://oglobo. globo.com/rio/novas-estacoes-do-bike-rio-geram-polemica-entre-moradoresdo-rio-22708867> . Acesso em 25 nov. 2018.

\section{PREFEITURA DE SÃO PAULO. Plano de Mobilidade da Cidade de Săo Paulo.}

Secretaria Municipal de Transportes, 2015. Disponível em: <https://www.prefeitura. sp.gov.br/cidade/secretarias/upload/chamadas/planmobsp_v072_1455546429.pdf〉. Acesso em: 9 jan. 2019.

Prefeitura Santana Tucuruvi e o ITDP realizam intervençăo urbana temporária. Prefeitura de Săo Paulo, Sáo Paulo, 18 set. 2017. Disponível em: ‘https://www. prefeitura.sp.gov.br/cidade/secretarias/subprefeituras/santana_tucuruvi/noticias/ index.php?p=76431 . Acesso em: 30 jan. 2019. 
RAO, Santosh. Understanding multimodality: An analysis of early JUMP users.

Medium Corporation, 19 jul. 2018. Disponível em: <https://medium.com/

uber-under-the-hood/understanding-multimodality-an-analysis-of-early-jump-users-4a35d647b7e6?. Acesso em: 20 jan. 2019.

REIS, Vivian. Greve dos caminhoneiros faz ciclovia bater recorde de utilizaçăo em Săo Paulo. G1, Săo Paulo, 30 mai 2018. Disponível em: <https://g1.globo.com/sp/ sao-paulo/noticia/greve-dos-caminhoneiros-faz-ciclovia-bater-recorde-de-utilizacao-em-sao-paulo.ghtml. Acesso em: 8 dez. 2018.

RIBEIRO, Gustavo. Bike Rio lidera o ranking do serviço em cidades do país. Mobilize, Săo Paulo, 4 jul. 2016. Disponível em: <http://www.mobilize.org.br/noticias/9699/ bike-rio-lidera-o-ranking-do-servico-em-cidades-do-pais.html>. Acesso em:07 dez. 2018.

ROSA, Elisa S., SCHROEDER, Timóteo. Bicicleta como objeto promotor da inclusáo social. XXVIII Congresso de Pesquisa e Ensino em Transporte - ANPET. Curitiba, 2014. Disponível em: <http://www.anpet.org.br/xxviiianpet/anais/documents/ AC366.pdf〉. Acesso em 8 jul. 2017.

SADIK-KHAN, Janette; SOLOMONOW, Seth. Street Fight: Handbook for an Urban

Revolution. New York: Penguin, 2016.

\section{SCHÜTZER, Kléber. A percepçăo do pedestre sobre a qualidade da paisagem}

urbana. Dissertaçấo (Mestrado em Engenharia Urbana) - Universidade Federal de Sáo Carlos, Sâo Carlos, 2011.

SCHROEDER, Bradley D. Bicycle Sharing 101: Getting the Wheels Turning. Moonshine Media, 2014.

SECRETARIA ESPECIAL DE COMUNICAÇĀO. Esclarecimentos sobre a Lei n ${ }^{\circ} 16.738$. Prefeitura de Sáo Paulo, Sáo Paulo, 9 nov. 2017. Disponível em: <http://www.capital. sp.gov.br/noticia/esclarecimentos-sobre-a-lei-no-16.738>. Acesso em: 8 jan. 2019.

SETO, Guilherme. Gestăo Dória planeja o empréstimo de até 10 mil bicicletas com Bilhete Único. Folha de S.Paulo, Săo Paulo, 21 set. 2017. Disponível em: <https:// www1.folha.uol.com.br/cotidiano/2017/09/1920493-doria-planeja-10-mil-bicicletas-emprestadas-com-bilhete-unico.shtml>. Acesso em: 9 jan. 2019. 
SHAHEEN, S.; GUZMAN, S.; ZHANG, H. Bikesharing in Europe, The Americas, and Asia: past, present, and future. Institute of Transportation Studies UC Davis - ITS. [California: s.n.], 2010. Disponível em: 〈http://escholarship.org/uc/item/79v822k5>. Acesso em: 08 jan. 2019.

SILVA, Eduardo. Rede Nossa Sâo Paulo lança $12^{a}$ ediçăo da Pesquisa de Mobilidade Urbana. Mobilidade Sampa, Sáo Paulo, 19 set. 2018. Disponível em: <https:// mobilidadesampa.com.br/2018/ 09/rede-nossa-sao-paulo-lanca-12a-edicao-da-pesquisa-de-mobilidade-urbana/>. Acesso em: 14 jan. 2019

SILVA, Ricardo Corrêa. A Bicicleta no Planejamento Urbano: Situaçáo e perspectiva da inserçáo da bicicleta no planejamento de mobilidade em Sáo Paulo e no Brasil. Sáo Paulo, Dissertaçăo de Mestrado FAUUSP, 2014.

SPECK, Jeff. Cidade caminhável. Traduçăo Anita Di Marco. 1. Ed. Săo Paulo: Perspectiva, 2016.

SOARES, Roberta. A Revoluçăo da Ciclomobilidade. Jornal do Commercio, Recife, 22 set. 2018. Disponível em: <http://especiais.jconline.ne10.uol.com.br/exemplodefortaleza/>. Acesso em: 25 jan. 2019.

SOLÍS, Arturo. Scooters elétricos de Grin suspenden servicio por regulación. Forber, México, 17 out. 2018. Disponível em: <https://www.forbes.com.mx/scooters-electricos-de-grin-suspenden-servicio-por-regulacion/>. Acesso em: 11 jan. 2019.

TAYLOR, Alan. The Bike-Share Oversupply in China: Huge Piles of Abandoned and Broken Bicycles. The Atlantic, Boston, 22 mar. 2018. Disponível em: <https://www. theatlantic.com/photo/2018/03/bike-share-oversupply-in-china-huge-piles-of -abandoned-and-broken-bicycles/556268/>. Acesso em: 5 jan. 2018.

TRANSPORTE ATIVO (2018a). Oficina Sistemas de Bicicletas Públicas e

Compartilhadas. Rio de Janeiro, 2018a. Disponível em: <http://www.transporteativo. org.br/temp/2018/ROBPC.pdf>. Acesso em 29. Jan 2019.

(2015). Parceira Nacional pela Mobilidade por Bicicleta: Pesquisa Perfil do

Ciclista. Rio de Janeiro, 2015. Disponível em: <http://www.ta.org.br/perfil/ciclista. pdf>. Acesso em 24 dez. 2018. 
(2018b). Parceria Nacional pela Mobilidade por Bicicleta: Pesquisa Perfil

do Ciclista 2018. Rio de Janeiro, 2018b. Disponível em: <http://ta.org.br/perfil/ ciclista18.pdf>. Acesso em: 14 jan. 2019.

VASCONCELLOS, Eduardo Alcântara. Mobilidade urbana: o que você precisa saber. Săo Paulo: Companhia das Letras, 2013.

VORMITTAG, Evangelina; DELGADO, Juliana. Relatório de poluiçăo do ar durante a greve dos caminhoneiros no Brasil. Instituto Saúde e Sustentabilidade. Săo Paulo, 2018. Disponível em: < https://www.saudeesustentabilidade.org.br/wp-content/ uploads/2018/07/Relatorio_GreveCaminhoneiros_13.07.18-1.pdf〉. Acesso em: 14 jan. 2019.

WRI BRASIL (2016). Estudo mostra como Sáo Paulo poderia ampliar o acesso a um transporte público de qualidade para 70\% da populaçăo. WRI Brasil, Porto Alegre, 13 set. 2016. Disponível em: <http://wricidades.org/noticia/ estudo-mostra-como-s\%C3\%A3o-paulo-poderia-ampliar-o-acesso-um-transporte -p\%C3\%BAblico-de-qualidade>. Acesso em: 1 set. 2018.

(2018a). Mobilidade năo é sinónimo de transporte. WRI Brasil, Săo Paulo, 15 ago. 2018. Disponível em: <https://wribrasil.org.br/pt/blog/2018/08/mobilidade-n\%C3\%A3o-\%C3\%A9-sin\%C3\%B4nimo-de-transporte>. Acesso em: 1 fev. 2019.

(2018b). Qual o impacto da poluiçăo do ar na saúde. WRI Brasil, Săo Paulo, 27 jul. 2018. Disponível em: ‘https://wribrasil.org.br/pt/blog/2018/07/qual-o-impactoda-poluicao-do-ar-na-saude?utm_source=facebook\&utm_medium=social\&utm_camp aign=qual-o-impacto-da-poluicao\%20-do-ar-na-saude\&fbclid=IwAR3DpIDaVieGWrgb S3ak_LWefNgKhnoTpwTDE64VB1VBBXrwd9M7FRE\%20mTYs>. Acesso em: 27 out. 2018.

YASBEK, Priscila; CARDOZO, Bárbara. Transporte por carro custa R\$ 20 mil por ano em Sáo Paulo, aponta estudo. G1 Globo, Săo Paulo, 14 jan. 2019. Disponível em: 〈https:// g1.globo.com/sp/sao-paulo/noticia/2019/01/14/transporte-por-carro-custa-r-20-mil -por-ano-em-sao-paulo-aponta-estudo.ghtml. Acesso em: 25 jan. 2019.

ZEE, Renate van der. How this Amsterdam inventor gave bike-sharing to the world. The Guardian, Londres, 26 abr. 2016. Disponível em: <https://www.theguardian. com/ cities/2016/apr/26/story-cities-amsterdam-bike-share-scheme>. Acesso em: 7 jul. 2018. 


\section{Legislação}

BRASIL. Lei $\mathbf{n}^{0}$ 9.503, de 23 de setembro de 1997. Institui o Código de Trânsito Brasileiro. Disponível em: 〈http://www.planalto.gov.br/ccivil_03/LEIS/L9503.htm〉. Acesso em: 25 jan. 2019.

BRASIL. Lei $\mathbf{n}^{\circ}$ 12.587, de 3 de janeiro de 2012. Institui as diretrizes da Política Nacional de Mobilidade Urbana; revoga dispositivos dos Decretos-Leis nos 3.326, de 3 de junho de 1941, e 5.405, de 13 de abril de 1943, da Consolidaçăo das Leis do Trabalho (CLT), aprovada pelo Decreto-Lei ${ }^{\circ} 5.452$, de $1^{\circ}$ de maio de 1943 , e das Leis nos 5.917, de 10 de setembro de 1973, e 6.261, de 14 de novembro de 1975; e dá outras providências. Disponível em: 〈http://www.planalto.gov.br/CCIVIL_03/_ Ato2011-2014/2012/Lei/L12587.htm>. Acesso em: 25 jan. 2019.

BRASIL. Resoluçáo $\mathbf{n}^{\mathbf{0}} \mathbf{4 6 5}$, de 27 de novembro de 2013. Conselho Nacional de Trânsito. Dá nova redaçáo ao art. $1^{\circ}$ da Resoluçáo n 315, de 8 de maio de 2009, do Contran, que estabelece a equiparaçáo dos veículos ciclo-elétrico, aos ciclomotores e os equipamentos obrigatórios para conduçăo nas vias públicas abertas à circulaçăo e dá outras providências. Disponível em: <http://www.lex.com.br/legis_25174467. RESOLUCAO_N_465_DE_27_DE_NOVEMBRO_DE_2013.aspx>. Acesso em: 26 jan. 2019.

SÂO PAULO (Cidade). Comunicado para Manifestaçăo de Interesse. Diário Oficial [da] Cidade de Sáo Paulo, Sáo Paulo, SP, 16 jan. 2016. Disponível em: <http://www.docidadesp.imprensaoficial.com.br/NavegaEdicao.aspx?ClipID=F131L98MPKV2He2K1GOCN5HT2KC\&PalavraChave=esta\%E7\%F5es\%20de\%20 autoatendimento>. Acesso em: 26 jan. 2019.

SÂO PAULO (Cidade). Chamamento Público n 01/2015 - SMT. Diário Oficial [da] Cidade de Sáo Paulo, Săo Paulo, SP, 13 maio 2015. Disponível em: <https://www. imprensaoficial.com.br/Certificacao/GatewayCertificaPDF.aspx?notarizacaoID=ee4a1a22-615f-4620-8212-e0172d59d5aa>. Acesso em: 26 jan. 2019.

SÂO PAULO (Cidade). Decreto $\mathbf{n}^{\mathbf{3}} \mathbf{3 4 . 8 5 4}$, de 3 de fevereiro de 1995. Regulamenta a lei $n^{\circ} 10.907$, de 23 de setembro de 1990, e dá outras providências. Disponível em: <https://leismunicipais.com.br/a/sp/s/sao-paulo/decreto/1995/3485/34854/ decreto-n-34854-1995-regulamenta-a-lei-n-10907-de-18-de-dezembro-de-1990-eda-outras-providencias>. Acesso em: 25 jan. 2019. 
SĂO PAULO (Cidade). Decreto $\mathbf{n}^{\circ} \mathbf{5 2 . 0 6 2}$, de 30 de dezembro de 2010. Confere nova regulamentaçăo ao artigo 50 da Lei n 14.223, de 26 de setembro de 2006, o qual dispôe sobre a celebraçâo de termos de cooperaçấo com a iniciativa privada, visando à execuçấo e manutençăo de melhorias urbanas, ambientais e paisagísticas, bem como à conservaçáo de áreas municipais, em consonância com o disposto no artigo 24 da Lei $n^{\circ} 14.517$, de 16 de outubro de 2007; acresce o $\S 3^{\circ}$ ao artigo $2^{\circ}$ do Decreto $n^{\circ} 40.384$, de 3 de abril de 2001, que dispóe sobre a doaçăo de bens e serviços e o estabelecimento de parcerias com a iniciativa privada; revoga o Decreto ${ }^{\circ} 50.077$, de 6 de outubro de 2008. Disponível em: <https://www.legisweb.com.br/legislacao/?id=179716 . Acesso em: 26 jan. 2019.

SÂO PAULO (Cidade). Decreto $\mathbf{n}^{\circ} \mathbf{5 7 . 8 8 9}$, de 21 de setembro de 2017. Dispóe sobre o compartilhamento de bicicletas em vias e logradouros públicos do Município de Săo Paulo. Disponível em: <http://legislacao.prefeitura.sp.gov.br/leis/decreto-57889-de21-de-setembro-de-2017>. Acesso em: 26 jan. 2019.

SÂO PAULO (Cidade). Decreto $\mathbf{n}^{\circ} \mathbf{5 8 . 5 1 6}$, de19 de novembro de 2018. Institui o Comitê de Crise de Pontes e Viadutos no Gabinete do Prefeito e estabelece providências correlatas. Disponível em: < https://leismunicipais.com.br/a/sp/s/sao-paulo/ decreto/2018/5852/58516/decreto-n-58516-2018-institui-o-comite-de-crisede-pontes-e-viadutos-no-gabinete-do-prefeito-e-estabelece-providencias-correlatas>. Acesso em: 27 jan. 2019.

\section{SÂO PAULO (Cidade). Instruçáo Normativa Secretaria Municipal das Prefeituras}

Regionais - SMPR n ${ }^{\circ} 2$ de 13 de setembro de 2018. Dispóe sobre a expediçâo do Termo de Permissâo de Uso - TPU para o uso de vias e logradouros públicos para a instalaçáo de sistema de compartilhamento de bicicletas, com ou sem estaçáo física. Disponível em: < http://legislacao.prefeitura.sp.gov.br/leis/instrucao-normativasecretaria-municipal-das-subprefeituras-smsub-2-de-13-de-setembro-de-2018〉. Acesso em: 26 jan. 2019.

SĂO PAULO (Cidade). Lei $\mathbf{n}^{\circ}$ 10.907, de 18 de dezembro de 1990. Dispóe sobre a destinaçăo de espaços para ciclovias no município de Sáo Paulo, e dá outras providências. Disponível em: 〈http://legislacao.prefeitura.sp.gov.br/leis/lei-10907de-18-de-dezembro-de-1990>. Acesso em: 25 jan. 2019. 
SÂO PAULO (Cidade). Lei nº 14.266, de 6 de fevereiro de 2007. Dispóe sobre a criaçăo do Sistema Cicloviário no Município de Săo Paulo e dá outras providências. Diário

Oficial [da] Cidade de Sáo Paulo, Sáo Paulo, SP, 7 fev. 2007. Disponível em:〈http:// www.imprensaoficial.com.br/Certificacao/GatewayCertificaPDF.aspx?notarizacaoID=734b232e-03f9-47c8-85e1-652618df3ef5 >. Acesso em: 25 jan. 2019.

SÂO PAULO (Cidade). Lei n ${ }^{\circ} 14.266$, de 7 de novembro de 2017. Altera a Lei nº 14.266, de 06 de fevereiro de 2007, que dispóe sobre o Sistema Cicloviário do Município de Săo Paulo, e dá outras providências. Diário Oficial [da] Cidade de Săo Paulo, Sáo Paulo, SP, 8 nov. 2017. Disponível em: <http://diariooficial.imprensaoficial.com.br/ nav_v4/index.asp?c=1\&e=20171108\&p=1 >. Acesso em: 25 jan. 2019.

SÂO PAULO (Cidade). Lei $\mathbf{n}^{\circ} \mathbf{1 6 . 0 5 0}$, de 31 de julho de 2014. Aprova a política de desenvolvimento urbano e o Plano Diretor Estratégico do Município de Săo Paulo e revoga a Lei no 13.430/2002. Disponível em: <https://leismunicipais.com.br/a/ sp/s/sao-paulo/lei-ordinaria/2014/1605/16050/lei-ordinaria-n-16050-2014-aprova-a-politica-de-desenvolvimento-urbano-e-o-plano-diretor-estrategico-do-municipio-de-sao-paulo-e-revoga-a-lei-n-13430-2002 >. Acesso em: 25 jan. 2019.

SÃO PAULO (Cidade). Lei ${ }^{\circ}$ 16.388, de 5 fe fevereiro de 2016. Institui o Programa IntegraBike Săo Paulo, e dá outras providências. Disponível em: < http://legislacao.prefeitura. sp.gov.br/leis/lei-16388-de-05-de-fevereiro-de-2016>. Acesso em: 26 jan. 2019.

SĂO PAULO (Cidade). Lei ${ }^{\circ} \mathbf{1 6 . 6 7 3}$, de 13 de junho de 2017. Institui o Estatuto do Pedestre no Município de Săo Paulo, e dá outras providências. Disponível em: < http:// documentacao.camara.sp.gov.br/iah/fulltext/leis/L16673.pdf>. Acesso em: 27 jan. 2019.

SÂO PAULO (Cidade). Lei Orgânica do Município de Săo Paulo. (Atualizada até a emenda 39/15). 2017. Disponível em: <https://www.sinesp.org.br/images/40_-_LEI_ ORGANICA_DO_MUNICIPIO_DE_SAO_PAULO_ATUALIZADA_ATE_A_EC_39_2015.pdf $>$. Acesso em: 30 jan. 2019. 


\section{SÂO PAULO (Cidade). Portaria Secretaria Municipal de Mobilidade e Transportes}

SMT/DSV n ${ }^{\mathbf{1 0 8}}$, de 18 de outubro de 2018. Dispóe sobre a obrigatoriedade de instalaçâo de sinalizaçâo de trânsito pelas Operadoras de Tecnologia de Transporte Credenciadas - OTTCs nas Áreas destinadas à locaçăo de bicicletas nas vias e logradouros públicos, com ou sem estaçăo. Disponível em: 〈http://legislacao.prefeitura. sp.gov.br/leis/portaria-secretaria-municipal-de-mobilidade-e-transportes-smt -dsv-108-de-18-de-outubro-de-2018/consolidado>. Acesso em: 26 jan. 2019.

\section{SÂO PAULO (Cidade). Portaria Subprefeitura de Pinheiros SUB/PI n 16, de 31 de}

outubro de 2018. Regulamenta o procedimento administrativo interno necessário para instalaçâo de estaçôes e áreas para demarcaçâo de estacionamento, em vias e logradouros públicos, destinadas à locaçăo de bicicletas, nos distritos de Pinheiros, Alto de Pinheiros, Itaim Bibi e Jardim Paulista. Disponível em: < http://legislacao. prefeitura.sp.gov.br/leis/portaria-subprefeitura-de-pinheiros-sub-pi-16-de-31-deoutubro-de-2018>. Acesso em: 26 jan. 2019.

SÂO PAULO (Cidade). Resoluçáo n¹7, de 12 de dezembro de 2017. Regulamenta o credenciamento das Operadoras de Tecnologia de Transporte Credenciadas - OTTCs para exploraçăo do serviço de compartilhamento de bicicletas disponibilizado nas vias e logradouros públicos. Disponível em: <https://www.prefeitura.sp.gov.br/ cidade/secretarias/upload/transportes/cmuv/resolucao_bike_sharing_12_12_17.pdf>. Acesso em: 26 jan. 2019.

SÂO PAULO (Cidade). Revogaçăo do Chamamento Público nº 01/2015 - SMT. Diário Oficial [da] Cidade de Sáo Paulo, Sáo Paulo, SP, 15 dez. 2015. Disponível em: <https:// www.imprensaoficial.com.br/Certificacao/GatewayCertificaPDF.aspx?notarizacaoI$\mathrm{D}=1 \mathrm{~b} 2 \mathrm{fdf9}$ 4-9067-4ba3-bcca-c586e1f5c483>. Acesso em: 26 jan. 2019.

SÂO PAULO (Cidade). Termo de Autorizaçáo Extraordinário. Subprefeitura de Pinheiros. Sâo Paulo, SP, 08 dez. 2018, Disponível em: <https://www.jusbrasil.com.br/ diarios/221151467/dosp-cidade-08-12-2018-pg-10 . Acesso em: 30 jan. 2019. 


\section{Referências eletrônicas}

ARO 60. Disponível em: <https://www.aromeiazero.org.br/>. Acesso em: 14 jan. 2019.

BICYCLE SHARING 101. Bicycle Sharing 101: getting the wheels turning, 2018.

Disponível em: <https://bicyclesharing101.com/>. Acesso em: 5 ago. 2018.

BIKXI. Disponível em: 〈https://bikxi.com.br/>. Acesso em: 14 jan. 2019.

BIKEITAU. Disponível em: <https://bikesampa.tembici.com.br/>. Acesso em: 28 maio 2018.

CALOI. Disponível em: 〈http://www.caloi.com/a-caloi/〉. Acesso em: 1 dez. 2018.

CEBRAP. Disponível em: 〈https://cebrap.org.br/>. Acesso em: 1 dez. 2018.

CICLOSAMPA. Disponível em: <https://ciclos ampa.pegbike.com.br/ciclosampa/ index.php>. Acesso em: 14 jan. 2019.

CITIBIKE. Disponível em: 〈https://www.citibikenyc.com/about>. Acesso em: 19 jan. 2019.

ECOBICI. Disponível em: 〈https://www.ecobici.cdmx.gob.mx/>. Acesso em: 20 jun. 2018.

GEOSAMPA. Disponível em: <http://geosampa.prefeitura.sp.gov.br/PaginasPublicas/ _SBC.aspx>. Acesso em: 16 jan. 2019.

GRIN. Disponível em: < https://ongrin.com/>. Acesso em: 14 jan. 2019.

IBGE. Disponível em: 〈https://cidades.ibge.gov.br/brasil/sp/sao-paulo/panorama〉. Acesso em: 15 jan. 2019.

ITDP. Disponível em: 〈http://itdpbrasil.org/>. Acesso em: 1 dez. 2018.

METROBIKE. Disponível em: ‘https://bike-sharing.blogspot.com>. Acesso em: 17 abr. 2018.

METRO NEWS. Disponível em: <http://www.metronews.fr/>. Acesso em: 14 jul. 2018

WRI. Disponível em: <https://www.wri.org/>. Acesso em: 1 dez. 2018.

WRI BRASIL. Disponível em: <http://wricidades.org/>. Acesso em: 1 dez. 2018.

YELLOW. Disponível em: <https://www.yellow.app/?gclid=EAIaIQobChMIw4Cmz-

Mrt3wIVFwmRCh3kcgTwEAAYASAAEgKOuPD_BwE>. Acesso em: 14 jan. 2019. 


\section{Onde encontrar}

\section{Figuras}

Figura 3|Disponivel em: <https://mitrerealty.com.br/empreendimentos/hausmitrebutanta>. Acesso em: 15 jan. 2019.

Figura 8|Disponivel em: <https://www.weelz.fr/fr/la-rochelle-1976-velo-jaune-libre-serviceautomobile-pollution/>. Acesso em: 19 jan. 2019.

Figura 9 | Disponivel em: <https://www.pedal.com.br/bicicletas-ciclistas-e-o-codigo-detransito-brasileiro_texto11402.html>. Acesso em: 24 dez. 2018.

Figura 14 | Disponível em: https://www.yellow.app/. Acesso em: 8 jan. 2019.

\section{Fotos}

Foto 3 | Disponivel em:<http://nva.org.uk/artwork/witte-fietsenplan-white-bikeplan/\#tab-2>. Acesso em 19 jan. 2019.

Foto 4 | Disponivel em:<http://nva.org.uk/artwork/witte-fietsenplan-white-bikeplan/\#tab-2>. Acesso em: 19 jan. 2019.

Foto 5 | Disponivel em:<https://historiek.net/provo-pleitte-in-1965-voor-elektrischefiets/58943/>. Acesso em 14 de jul. de 2018.

Foto 6 | Disponivel em: <http://bike-sharing.blogspot.com.br/2008/10/before-copenhagenearly-2nd-generation.html>. Acesso em: 19 jan. 2019.

Foto 7 | Disponivel em: https://www.flickr.com/photos/jeanlouis_ zimmermann/4842341480/sizes///

Foto 8 | Disponivel em:<https://frenchly.us/spokefolksbikethecityoflights/velib-stationplace-du-havre-paris/>. Acesso em: 19 jan. 2019. 
Foto 9 | Disponivel em: <https://commons.wikimedia.org/w/index.php?curid=2226096>. Acesso em 19 jan. 2019.

Foto 10 | Disponível em:<http://montrealvisitorsguide.com/bixi-bicycles-montreal/>. Acesso em: 13 out. 2018.

Foto 11 | Disponível em:<https://cleantechnica.com/2015/09/29/worlds-top-8-bike-shareprograms/>. Acesso em: 13 out. 2018.

Foto 14 | Disponivel em: http://www.itdp-china.org/media/dbs/article/Dockless\%20 Bike\%20Share\%20(DBS)\%20in\%20China.pdf

Foto 15 | Disponivel em: https://www.itdp.org/2018/01/04/dockless-bikeshare-know-so-far/ Foto 16 | Disponivel em: https://www.theatlantic.com/photo/2018/03/bike-shareoversupply-in-china-huge-piles-of-abandoned-and-broken-bicycles/556268/ Foto 20 | Disponivel em:<https://qz.com/1235417/bluegogo-and-didi-what-happens-whenyour-bike-share-company-goes-out-of-business-in-china/>. Acesso em: 19 jan. 2019. Foto 21 | Disponivel em: < http://eliaspelcastre.com/2018/02/20/electric-bike-mexicocity?amp=1>. Acesso em: 20 jan. 2019.

Foto 22 | Disponivel em:<https://www.bicing.barcelona/>. Acesso em: 20 jan. 2019. Foto 23 | Disponivel em:<https://www.theurbanist.org/2018/07/25/after-a-year-ofbikeshare-battles-lime-is-winning/>. Acesso em: 20 jan. 2019.

Foto 26 | Disponível em: <https://techcrunch.com/2018/12/12/scoot-unveils-new-lock-toprevent-scooter-theft/>. Acesso em: 25 jan. 2019.

Foto 27 | Disponível em:<https://ciclovivo.com.br/arq-urb/mobilidade/patinetes-eletricoscompartilhados-rj/>. Acesso em: 20 jan. 2019

Foto 28|Disponivel em: <https://bicicreteiro.org/2011/04/14/porque-o-ciclista-cometeinfracoes-de-transito/>. Acesso em 8 jan. 2019.

Foto 29 |Disponível em: <https://bicicreteiro.org/2011/04/14/porque-o-ciclista-cometeinfracoes-de-transito/>. Acesso em 8 jan. 2019.

Foto 34 |Disponivel em: < http://www.capital.sp.gov.br/noticia/terminal-cidade-tiradentesrecebe-estacao-de-compartilhamento-de-bicicletas>. Acesso em: 15 jan. 2019. 
Foto 35 |Disponível em:<http://www.capital.sp.gov.br/noticia/terminal-cidade-tiradentesrecebe-estacao-de-compartilhamento-de-bicicletas>. Acesso em: 15 jan. 2019.

Foto 37|Disponível em:<http://picdeer.com/media/1936578554701498222_243049981>. Acesso em: 15 jan. 2019.

Foto 38|Disponivel em: <http://picdeer.com/media/1936578554701498222_243049981〉. Acesso em: 15 jan. 2019.

Foto 39|Disponivel em: <http://picdeer.com/media/1936578554701498222_243049981〉. Acesso em: 15 jan. 2019.

Foto 40 |Disponível em: <http://picdeer.com/media/1936578554701498222_243049981>. Acesso em: 15 jan. 2019.

Foto 42 |Disponivel em: <(http://ag.jor.br/blog/2016/02/02/contrato-bikesharing-itaubradesco/)>. Acesso em: 11 jan. 2019.

Foto 46 | Disponivel em: <https://www1.folha.uol.com.br/cotidiano/2018/08/uso-de-cicloviada-faria-lima-dispara-e-rush-e-para-ir-ao-trabalho.shtml>. Acesso em: 08 jan. 2019.

Foto 47 |Disponível em: < https://www1.folha.uol.com.br/cotidiano/2018/08/uso-de-cicloviada-faria-lima-dispara-e-rush-e-para-ir-ao-trabalho.shtml>. Acesso em: 08 jan. 2019.

Foto 66 | Disponível em <http://thecityfixbrasil.com/2018/05/14/o-poder-de-transformacaodo-urbanismo-tatico/>. Acesso em 15 set. 2018.

Foto 67| Disponivel em <http://thecityfixbrasil.com/2018/05/14/o-poder-de-transformacaodo-urbanismo-tatico/>. Acesso em 15 set. 2018.

Foto 68|Disponivel em <http://thecityfixbrasil.com/2018/05/14/o-poder-de-transformacaodo-urbanismo-tatico/>. Acesso em 15 set. 2018.

Foto 69 |Disponível em <http://thecityfixbrasil.com/2018/05/14/o-poder-de-transformacaodo-urbanismo-tatico/>. Acesso em 15 set. 2018

Foto 70 |Disponível em: <https://www.mobilize.org.br/galeria-fotos/368/sao-paulo-trocafaixa-verde-por-calcada.html>. Acesso em 31 jan. 2019. 


\section{Gráficos}

Gráfico 1 | Disponível em: <https://newsonline.library.vanderbilt.edu/2018/07/new-resourcespotlight-statista/>. Acesso em: 10 jan. 2019.

Gráfico 2 | Disponivel em: <https://newsonline.library.vanderbilt.edu/2018/07/new-resourcespotlight-statista/>. Acesso em: 10 jan. 2019.

Gráfico 3 | Disponivel em: < http://bike-sharing.blogspot.com/2017/01/the-bike-sharingworld-at-end-of-2016.html>. Acesso em: 19 jan. 2019.

Gráfico 4 | Disponivel em: < http://bike-sharing.blogspot.com/2017/01/the-bike-sharingworld-at-end-of-2016.html>. Acesso em: 19 jan. 2019.

Gráfico 5 | Disponivel em: < https://www.statista.com/statistics/912746/number-of-bikesharing-programs-in-the-united-states/>. Acesso em: 10 jan. 2019.

Gráfico 8| Disponivel em: <http://www.itdp-china.org/media/dbs/article/Dockless\%20

Bike\%20Share\%20(DBS) \%20in\%20China.pdf>. Acesso em: 10 jan. 2019.

Gráfico 9 |Disponivel em: <https://nacto.org/bike-share-statistics-2017/> (<https://nacto.org/ wp-content/uploads/2018/05/NACTO-Bike-Share-2017.pdf>). Acesso em 05 de jan. de 2019.

Gráfico 11 |Disponivel em: <https://medium.com/uber-under-the-hood/understandingmultimodality-an-analysis-of-early-jump-users-4a35d647b7e6>. Acesso em: 20 jan. 2019. Gráfico 52 |Disponivel em: <http://www.cetsp.com.br/consultas/bicicleta/contadores-debicicletas.aspx >. Acesso em: 9 fev. 2019.

\section{Mapas}

Mapa 2 |Disponivel em: https://www.archdaily.com.br/br/873024/mobilidade-como-equidadea-proximidade-do-transporte-entre-diferentes-faixas-de-renda-nas-regioes-metropolitanasbrasileiras. Acesso em: 11 jan. 2019.

Mapa 13 |Disponivel em: https://ciclosampa.pegbike.com.br/ciclosampa/pg_estacoes.php. Acesso em: 11 jan. 2019. 




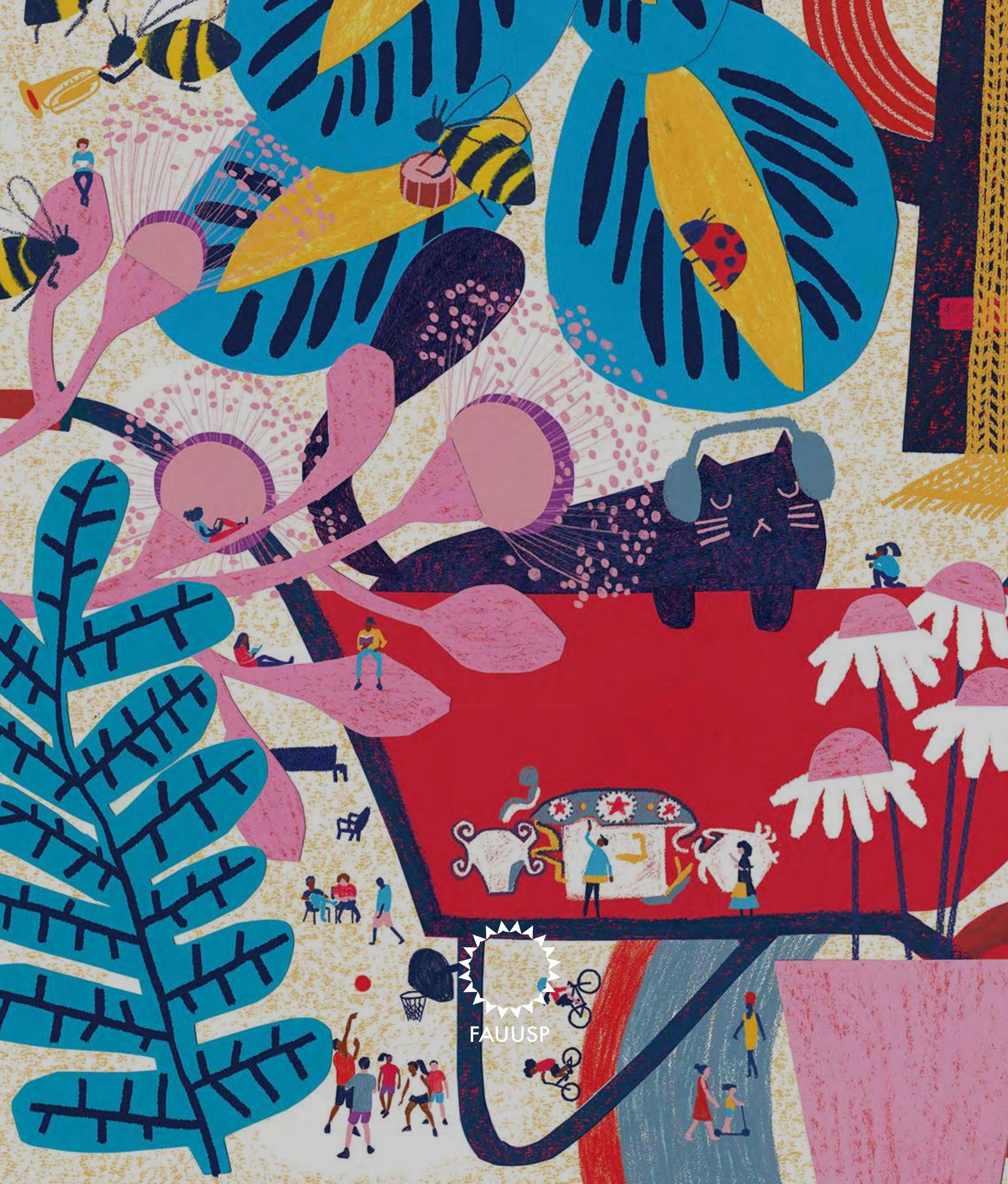

